Artigo original

Hegemonia - Revista Eletrônica do Programa de Mestrado em Direitos Humanos, Cidadania e Violência/Ciência Política do Centro Universitário Unieuro

ISSN: 1809-1261

UNIEURO, Brasília, número 24, Julho a Dezembro de 2018, pp. 110-259.

Recebido em: 26/1/2018

Avaliado em: 25/3/2018

Aprovado em: 2/5/2018

\title{
LA BANANA REPUBLIC: IMAGINARIOS BANANEROS DE LA IDENTIDAD HONDUREÑA REPRESENTADOS EN 100 TARJETAS POSTALES
}

\author{
Jorge Alberto Amaya ${ }^{1}$ \\ «La República de Honduras, tal como está diseñada \\ en la Constitución, no es una República para el común, \\ es una República de la propiedad, es para \\ proteger a la propiedad privada»... \\ (Manuel Gamero, QDDG, \\ Periodista hondureño)
}

RESUMEN: El artículo explora la construcción de la identidad nacional en Honduras desde la perspectiva de la historia cultural. Se utiliza como fuentes un conjunto de tarjetas postales sobre la producción de bananas y otras frutas tropicales desde el siglo XIX.

PALABRAS-CLAVE: Honduras; Historia cultural y social; Identidad.

ABSTRACT: The article explores the construction of national identity in Honduras from the perspective of cultural history. A set of postcards about the production of bananas and other tropical fruits since the 19th century is used as sources.

\footnotetext{
${ }^{1}$ Doutor em Estudos Latino-americanos. Docente da Universidade Pedagógica Nacional Francisco Morazán e da Universidade Nacional Autônoma de Honduras. Dedicado a Guillermo Varela, Arnulfo Ramírez e Edgar Soriano.
} 
Artigo original

Hegemonia - Revista Eletrônica do Programa de Mestrado em Direitos Humanos, Cidadania e Violência/Ciência Política do Centro Universitário Unieuro

ISSN: 1809-1261

UNIEURO, Brasília, número 24, Julho a Dezembro de 2018, pp. 110-259.

KEYWORDS: Honduras; Cultural and Social History; Identity.

1) Introducción

El presente trabajo forma parte de un estudio más amplio en el que estamos investigando y abordando diferentes imaginarios y representaciones sociales que se han forjado en Honduras a partir de iconografías plasmadas en sus tarjetas postales a lo largo del siglo XX y en lo que va del siglo XXI. En este caso, nos interesa examinar cuáles son algunos de los imaginarios expresados alrededor de lo que hemos denominado "postales bananeras", es decir, las cartas y tarjetas postales que sitúan sus representaciones en ámbitos que fueron controlados por el capital transnacional de las compañías bananeras, pero también las que surgieron en el ámbito del “enclave minero" alrededor de la compañía "Rosario Mining Company”, que se instaló en San Juancito, en las cercanías de Tegucigalpa en 1880, propiedad del magnate neoyorquino Washington Valentine.

En este sentido, nos interesa poder explorar y problematizar algunos puntos esenciales del tema en cuestión, entre otros: ¿Cómo contribuyeron estas imágenes a crear una idea interna y externa de Honduras como el arquetípico país Banana Republic?, ¿Cómo intentaban expresar la introducción de la noción de Modernidad en el país? ¿Cómo esas postales bananeras plasmaban discursos y dicotomías entre civilización versus barbarie?, ¿Cómo se representaba el producto el banano como tal- en las postales?, ¿Cómo se representaba al proletariado obrero, y al paisaje rural y urbano del entorno bananero en las postales?

El acervo documental que ha servido de soporte para el análisis de este estudio proviene de varias fuentes, sobre todo colecciones privadas a las que he tenido acceso, como "la Colección Fotográfica del poeta José Gonzáles Paredes", la "Colección Privada de tarjetas postales del artista fotógrafo Jorge Handal”, el archivo del artista fotógrafo Guillermo Bulnes de La Ceiba, así como mi colección privada de tarjetas postales. Asimismo, se han consultado fondos provenientes de las colecciones de sitios de Internet como "Ebay" y "Delcampe". 
Artigo original

Hegemonia - Revista Eletrônica do Programa de Mestrado em Direitos Humanos, Cidadania e Violência/Ciência Política do Centro Universitário Unieuro

ISSN: 1809-1261

UNIEURO, Brasília, número 24, Julho a Dezembro de 2018, pp. 110-259.

2) Aproximación al concepto de la "Banana Republic"

El término "Banana Republic" es hoy de uso corriente. Ha sido incorporado a los diccionarios de lengua inglesa con tres connotaciones distintas aunque complementarias: a) país pequeño, especialmente en América Central, especializado en la exportación de bananas (o de otro producto tropical); b) país dominado por intereses extranjeros, representados por unas pocas compañías dueñas de grandes concesiones; y c) país con un gobierno inestable, usualmente dictatorial, en el que se presentan revoluciones frecuentes o Golpes de Estado y una continua presencia de los militares en la política².

Asimismo, "Banana Republic" es un término peyorativo para un país que es considerado políticamente inestable, empobrecido y atrasado, cuya economía depende de unos pocos productos de escaso valor agregado (simbolizados por las bananas), gobernado por un dictador o una junta militar, muchas veces formando gobiernos autoritarios o fraudulentamente legitimados. También se las suele llamar "republiquetas bananeras".

Otro rasgo notable en este estereotipo es que en la "república bananera" la corrupción es práctica corriente en cada aspecto de la vida cotidiana, siendo comúnmente desobedecidas las leyes del país. También suele identificarse como característica de la república bananera el poder casi absoluto que ejerce sobre su gobierno una gran empresa extranjera (o varias de éstas), ya sea mediante sobornos a los gobernantes o por simple ejercicio de su poder financiero, apoyando a las élites o a la oligarquía local a gobernar, a través de la ideología imperialista, impulsando un tinte anticomunista a través de los medios.

El término fue acuñado por O. Henry, humorista y escritor de cuentos cortos estadounidense, que pasó varios años en Centroamérica. O. Henry vivió en la costa norte de Honduras, en la zona bananera, cerca de La Ceiba, y se inspiró en sus aventuras y en las historias de los campos

\footnotetext{
2 Véase; Pérez Brignoli, Héctor, "El fonógrafo en los trópicos: sobre el concepto de banana republic en la obra de
} O. Henry”, en: Revista Iberoamericana, Berlín, Instituto Ibero- Americano de N²3, 2006, pp. 127-142. 
Artigo original

Hegemonia - Revista Eletrônica do Programa de Mestrado em Direitos Humanos, Cidadania e Violência/Ciência Política do Centro Universitário Unieuro

ISSN: 1809-1261

UNIEURO, Brasília, número 24, Julho a Dezembro de 2018, pp. 110-259.

bananeros para escribir una novela en 1904 titulada Cabbages and Kings (Repollos y Reyes), que retrataba al país como una caricatura de sociedad al servicio de las compañías bananeras.

Además de O’Henry, otro importante literato norteamericano, Eugene O’Neill, -a la sazón Premio Nobel de literatura-, también contribuyó al montaje de discursividades que alimentaron el mito de Honduras como esencia de la "Banana Republic". Efectivamente, O’ Neill también vivió en Honduras durante un tiempo, alternando entre San Juancito y Tegucigalpa entre 1910 y principios de 1911, adonde se había afincado escapando de las responsabilidades de un matrimonio frustrado; en Honduras se dedicó a buscar fortuna lavando oro. Pronto cogió malaria, y tuvieron que trasladarlo en mula hasta Tegucigalpa; ahí lo alojaron para su recuperación en el antiguo edificio de la embajada (donde estaba el Viejo "Hotel Mc Arthur"). O’Neill en su convalecencia se dedicó a escribir algunos de sus primeros textos, infortunadamente, retratando a Honduras -según el parecer de don Julio Escoto- como "un infierno". Por supuesto, pocos extranjeros han escrito tan dura y maliciosamente sobre el país como este gringo. Una de sus "perlas" fue la siguiente:

Después de haber estado en todas las diferentes zonas de este país me rindo a la idea fija de que Dios obtuvo la inspiración para el infierno sólo tras haber creado a Honduras ${ }^{3}$.

Unos días después, en carta remitida a su hermana, firmada el 15 de mayo de 1910, despotrica con odio contra los hondureños, expresando que eran:

El más bajo, perezoso, el más ignorante puñado de bípedos descerebrados que jamás haya contaminado la tierra ${ }^{4}$.

Y remata diciendo:

Hasta que algún justo destino se canse de observar los tantaleos en la oscuridad de esta larva humana y entonces los extermine; hasta que el universo sacuda a estos piojos de sus costados,

\footnotetext{
${ }^{3}$ Citado en: Escoto, Julio, "Con ojos ajenos", En: Revista Imaginación, San Pedro Sula, Centro Editorial, Etapa III, $\mathrm{N}^{\circ} 7,2016$, p. 80.

${ }^{4}$ Ibíd., p. 80 .
} 
Artigo original

Hegemonia - Revista Eletrônica do Programa de Mestrado em Direitos Humanos, Cidadania e Violência/Ciência Política do Centro Universitário Unieuro

ISSN: 1809-1261

UNIEURO, Brasília, número 24, Julho a Dezembro de 2018, pp. 110-259.

Honduras carece de futuro, sin esperanza de ser otra cosa que lo que es al presente -una Siberia de los trópicos- ${ }^{5}$.

En suma, esta imagen ha sido la que ha imperado en gran parte del extranjero con respecto a Honduras, la cual se convirtió en el imaginario internacional como la arquetípica "Banana Republic". De manera que el peso de la injerencia bananera en la economía y la política del país, así como la descomunal fuerza del capital transnacional, sirvieron para que la imagen de Honduras como una sociedad "bananera" fuera divulgada también a través de las tarjetas postales; así, una gran cantidad de postales de esta temática fueron diseminadas por el mundo, exportando la imagen de Honduras como una "Banana Republic" por antonomasia. Por ello, este apartado dedicado en nuestro libro a las postales bananeras es de los que tiene más extensión, debido a la profusión de postales que se publicaron; en fin, tuvimos que hacer una exhaustiva selección de las mismas para mostrar un panorama general de los imaginarios que se quisieron divulgar a través de estas postales, los cuales iban en consonancia la mayoría de las veces con los intereses de las compañías bananeras transnacionales.

El grado de hegemonía que alcanzaron estas compañías fruteras sobre nuestros países fue aplastante. En la práctica, las naciones que quedaron sometidas al poder de las bananeras se convirtieron en "apéndices" o en "enclaves" de esas empresas y del imperialismo norteamericano. Para ilustrar esa aseveración, citamos el comentario de uno de los oficiales del cuerpo de "marines" norteamericanos que fueron usados por las compañías bananeras para sofocar rebeliones, huelgas o para obligar a las élites locales a ponerse al lado del capital extranjero: nos referimos al general Smedley Butler:

He servido durante 30 años y cuatro meses en las unidades más combativas de las Fuerzas Armadas estadounidenses: en los Marines. Tengo la sensación de haber actuado durante ese tiempo de bandido altamente calificado al servicio de las grandes empresas de Wall Street y sus banqueros. En otras palabras, he sido un pandillero al servicio del capitalismo. [...] En 1923 “enderecé" los asuntos en Honduras en interés de las compañías fruteras estadounidenses... Cuando miro hacia atrás considero que pude haber dado a Al Capone algunas sugerencias. Él,

\footnotetext{
${ }^{5}$ Ibíd., p. 80.
} 
Artigo original

Hegemonia - Revista Eletrônica do Programa de Mestrado em Direitos Humanos, Cidadania e Violência/Ciência Política do Centro Universitário Unieuro

ISSN: 1809-1261

UNIEURO, Brasília, número 24, Julho a Dezembro de 2018, pp. 110-259.

como gánster, operó en tres distritos de una ciudad. Yo. Como Marine, operé en tres continentes 6 .

Ha sido tan fuerte el peso del término "Banana Republic", que incluso recientemente la connotación se ha extendido a sinónimo de corrupción y manipulación en la política. El conocido economista Paul Krugman escribió hace poco: "many states [en los Estados Unidos] are being run like banana republics", mientras que un biólogo aplicó el término para caracterizar la forma en que en los Estados Unidos se distribuían los fondos para investigación en ese campo ${ }^{7}$. Y en 1998 un descorazonado periodista (Aníbal Antonio Romero Sanabria) comentaba titulares de la prensa paraguaya en que se aseguraba, citando al "Washington Post", que Paraguay era la "última República bananera".

El otro término asociado con el que se conoció la incursión de Honduras al capitalismo mundial a través de la economía bananera fue el de "Enclave", el cual alude a la situación de sometimiento de un Estado por otro Estado o por parte de corporaciones, es decir, de la inserción de "un Estado en otro Estado"; esta perspectiva fue desarrollada especialmente en América Latina, y fue conocida como "la teoría de la dependencia", por parte de autores como Fernando Henrique Cardozo y Enzo Falleto, quienes teorizaban que el desarrollo de los países centrales (Estados Unidos y Europa), se basaba en la explotación y expoliación de los recursos de los países periféricos 9 .

La noción de "Banana Republic" para caracterizar a Honduras no solamente fue funcional en el siglo $\mathrm{XX}$, sino que incluso en la actualidad tiene eco y repercusión a nivel interno y a nivel internacional, y se manifiesta tanto en la vida política, así como en aspectos cotidianos de la vida.

Por poner un ejemplo cotidiano, en el ámbito futbolístico, en el año 2013, en el marco de las eliminatorias mundialistas para el "Mundial de Brasil 2014", el polémico periodista mexicano

\footnotetext{
${ }^{6}$ Véase: Schmidt, Hans, Maverick Marine: General Smedley D. Butler and the Contradiction of American Military History, Lexinngton, Kentucky, University Press of Kentucky, 1987.

7 Petsko, Gregory, "Comment: Banana Republic". En: Genome Biology, Vol. 3, N. ${ }^{\circ}$ 12, consultado en: http://genomebiology.com/content/pdf/gb-2002-3-12-comment1016.pdf, (15.01.2006).

${ }^{8}$ Romero Sanabria, Aníbal Antonio, De la tierra sin mal a la... Republiqueta Bananera, Asunción, 1998.

${ }_{9}$ Cfr. Cardoso, Fernando Henrique y Falleto, Enzo, Dependencia y desarrollo en América Latina: ensayo de interpretación sociológica, Buenos Aires, Siglo XXI Editores, $1^{\text {a }}$ reimpresión, 2005.
} 
Artigo original

Hegemonia - Revista Eletrônica do Programa de Mestrado em Direitos Humanos, Cidadania e Violência/Ciência Política do Centro Universitário Unieuro

ISSN: 1809-1261

UNIEURO, Brasília, número 24, Julho a Dezembro de 2018, pp. 110-259.

David Faitelson, previo al partido entre México y Honduras en el Estadio Azteca, publicó una fotografía con un mazo de bananos en la mano, mientras sus compañeros de tertulia reían como monos, evidentemente mofándose de Honduras y los hondureños. Por infortunio para ellos, Honduras dio el batacazo en ese match, ganando 2 á 1 y haciendo realidad lo que desde entonces se conoce como "El Aztecazo", propinando a dicha selección una de sus mayores humillaciones futbolísticas.

\section{ILUSTRACIÓN 1}

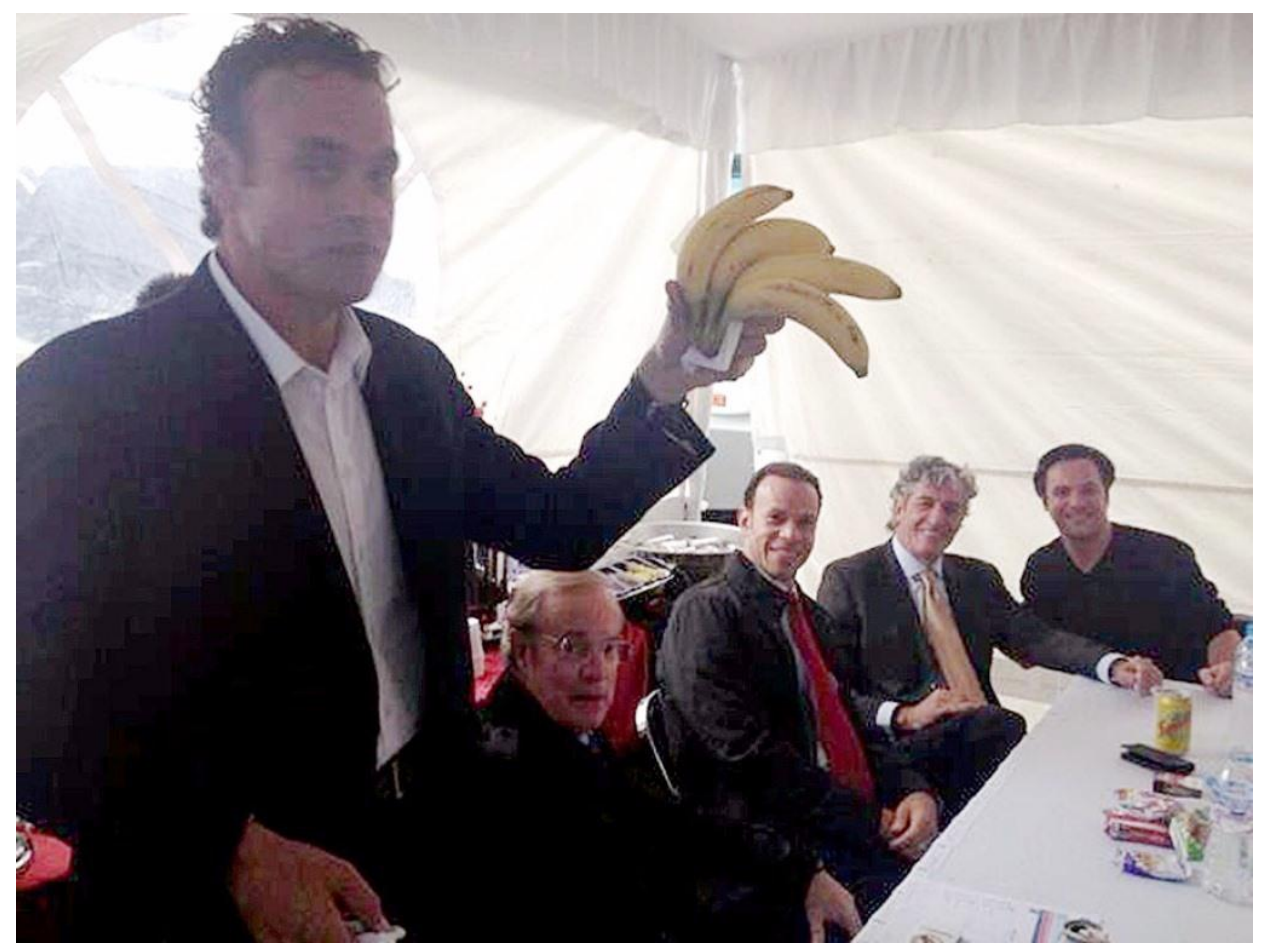

David Faitelson, burlándose de los hondureños posando con un mazo de bananos. (Fuente: Aristegui Noticias,

Denuncian a David Faitelson por promover el odio contra Honduras,

https://aristeguinoticias.com/0911/kiosko/denuncian-a-david-faitelson-por-promover-el-odio-contrahonduras/, Consultado el 6 de enero del 2018).

El mismo Estado de Honduras, a través de uno de sus emblemas, se arrogó ese "imaginario bananero" cuando en 1943 mandó a emitir una serie de "Sellos Postales" con la estampa de una 
Artigo original

Hegemonia - Revista Eletrônica do Programa de Mestrado em Direitos Humanos, Cidadania e Violência/Ciência Política do Centro Universitário Unieuro

ISSN: $1809-1261$

UNIEURO, Brasília, número 24, Julho a Dezembro de 2018, pp. 110-259.

mata de bananos, reconociendo por ende su territorio, paisaje, identidad e historia vinculados al cultivo de bananas.

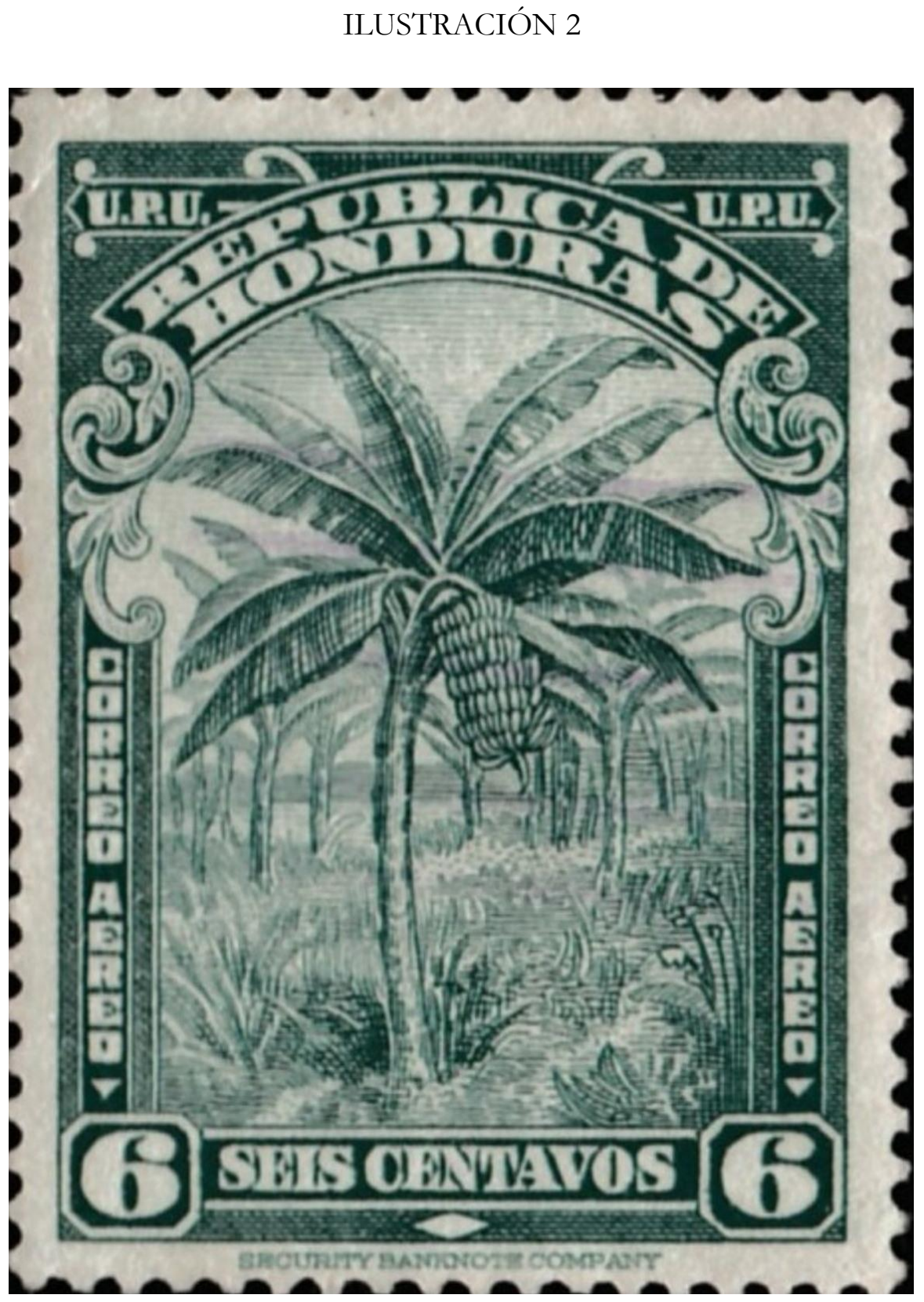

Estampilla de la colección de sellos postales emitida por la República de Honduras en 1943 en la que sobresale el banano como símbolo de la cultura, historia e identidad hondureña. (Tomada de: https://www.delcampe.net/es/coleccionismo/sellos/honduras/search). 
Artigo original

Hegemonia - Revista Eletrônica do Programa de Mestrado em Direitos Humanos, Cidadania e Violência/Ciência Política do Centro Universitário Unieuro

ISSN: 1809-1261

UNIEURO, Brasília, número 24, Julho a Dezembro de 2018, pp. 110-259.

Asimismo, en la esfera de la producción artística y cultural, varios intelectuales y artistas hondureños, a lo largo del siglo XX, han creado obras que recurren al tópico de la presencia bananera en los imaginarios y mentalidades colectivas catrachas; uno de ellos, el renombrado artista Arturo López Rodezno, fundador de la "Escuela Nacional de Bellas Artes" (ENBA), y forjador de las estéticas y vanguardias artísticas hondureñas en los años cuarenta, aportó una de las primigenias obras pictóricas de temática bananera, en la cual se hace una lectura interesantísima de la posición y lugar del banano dentro de la nación: es una estampa o dibujo al grafito en la que posa una mujer desnuda (naturalmente la metáfora es Honduras, o mejor la "Madre Patria"), en medio de un campo cubierto de bananos: 
Artigo original

Hegemonia - Revista Eletrônica do Programa de Mestrado em Direitos Humanos, Cidadania e Violência/Ciência Política do Centro Universitário Unieuro

ISSN: 1809-1261

UNIEURO, Brasília, número 24, Julho a Dezembro de 2018, pp. 110-259.

\section{ILUSTRACIÓN 3}

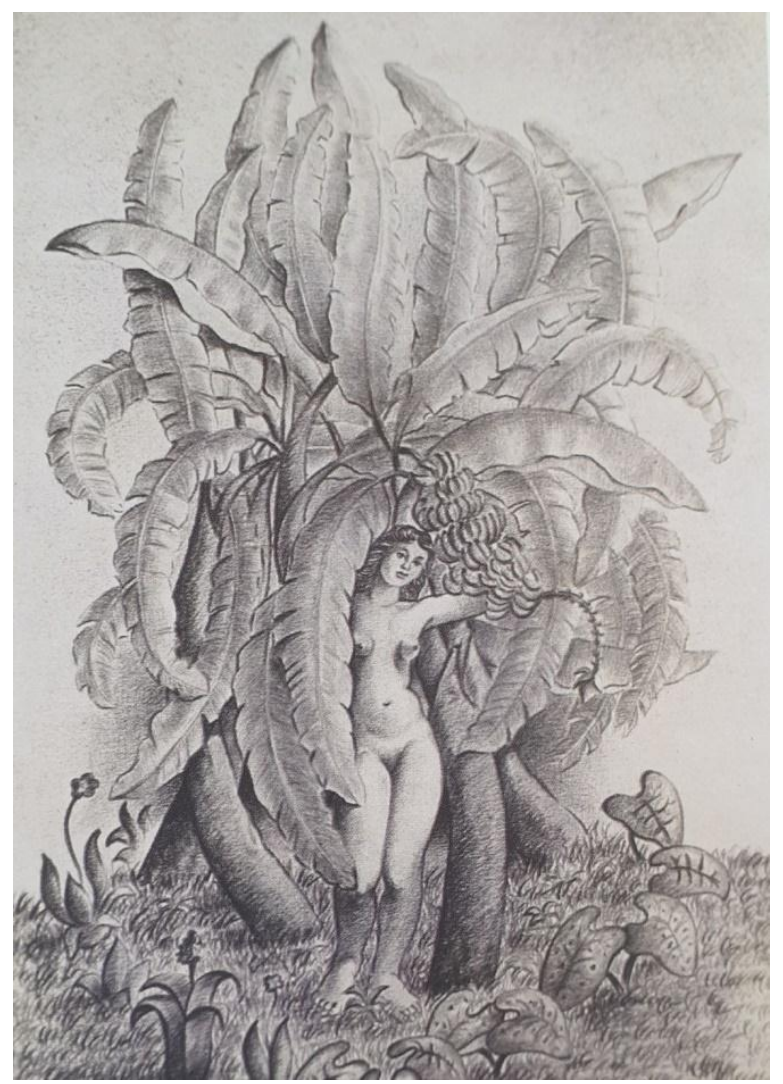

“Obra: Sin título”, de Arturo López Rodezno (Colección Familia López, reproducida en: Barahona, Joel, “Arturo López Rodezno y su aporte a la identidad nacional”, En: Revista Arte \&Cultura (CAC-UNAH), Tegucigalpa, Vol. I, No 1, junio-diciembre 2014, pp. 44-60.

Naturalmente, la exposición de la mujer desnuda en el bananal sugería que Honduras, como territorio virginal y sin desarrollo, se "ofrecía" al destino de las compañías bananeras para convertir al banano en la fuente de su futura "riqueza". Es decir, se repiten los mismos tópicos e imaginarios que sobre "Nuestra América" se han reiterado desde la Conquista europea.

Por otro lado, con relación a la literatura, algunas de las principales obras hondureñas están inspiradas en la temática bananera: la más antigua es la novela antiimperialista Prisión verde de Ramón Amaya Amador, obra fundamental y referencia obligada en los estudios sobre literatura 
Artigo original

Hegemonia - Revista Eletrônica do Programa de Mestrado em Direitos Humanos, Cidadania e Violência/Ciência Política do Centro Universitário Unieuro

ISSN: 1809-1261

UNIEURO, Brasília, número 24, Julho a Dezembro de 2018, pp. 110-259.

bananera de América Latina, junto a Mamita Yunai de Carlos Luis Falla, y el Papa Verde de Miguel Ángel Asturias. La otra más reciente es la magistral novela de Roberto Quesada Los barcos, publicada en los años ochenta.

Igualmente, en la producción cinematográfica hondureña destaca una obra trascendental en donde se desafía e interpela el significado del mito de la "Banana Republic", cuando se filmó la irreverente película "Utopía", del famoso cineasta chileno Raúl Ruíz en 1975. Efectivamente, Raúl Ruíz ${ }^{10}$ llegó a Honduras procedente de Francia, donde se encontraba exiliado, y filmó la película Utopía.

La película Utopía, titulada en francés Le corps divisé et le monde à l'envers, fue otra obra además de experimental- sorprendente, irreverente y única dentro de la cinematografía hondureña de todos los tiempos, rayando en lo que el cineasta hondureño Carlos Ordóñez ha denominado como la "cinematografía del absurdo"11.

En efecto, Utopía es una historia no solo irreverente y atrevida, sino que está fuera de todo paradigma dentro de la cinematografía que se solía hacer en América Latina por aquella época. La escena inicial es de por sí insolente y transgresora: en dicha escena aparece un indígena hondureño -óigase bien- ¡cagando bananos!. En un país caracterizado peyorativamente como "Banana Republic" y con una oligarquía sumisa y supeditada al imperialismo yanqui, esta escena resulta absolutamente rebelde y perturbadora a los ojos de una sociedad conservadora y santurrona.

\footnotetext{
10 Raúl Ruíz nació en Puerto Montt, Chile, en 1941. Después del golpe de Estado de 1973, se radicó en Francia, país en el que alcanzó notoriedad internacional a principios de los años ochenta con películas como Las tres coronas del marinero (1983) y La isla del tesoro (1985).

Se destaca por su amplia producción cinematográfica, habiendo dirigido más de 200 películas, en las que se alternan los formatos $35 \mathrm{~mm}$., $16 \mathrm{~mm}$. y video, entre las cuales también figuran superproducciones con grandes estrellas europeas y norteamericanas como John Malkovich, Marcello Mastroianni, Catherine Deneuve o John Hurt. Durante un tiempo formó parte de una generación de directores chilenos políticamente comprometidos, como Miguel Littín y Helvio Soto, pero gradualmente se le catalogó como un autor distinto, que creaba películas cada vez más intelectuales, surrealistas, irónicas y experimentales. Es considerado por muchos como el cineasta chileno más importante de la historia.

11 Ordóñez, Carlos, "Utopía: el espejo roto de la hondureñidad”, En: Revista Nosotros, Tegucigalpa, N 1, Año I, abril del 2009, pp. 40-41.
} 
Artigo original

Hegemonia - Revista Eletrônica do Programa de Mestrado em Direitos Humanos, Cidadania e Violência/Ciência Política do Centro Universitário Unieuro

ISSN: 1809-1261

UNIEURO, Brasília, número 24, Julho a Dezembro de 2018, pp. 110-259.

En concreto, es difícil exponer el argumento de esta obra, pues incluso originalmente carecía de guión, pero en general, Carlos Ordóñez describe sobre Utopía lo siguiente:

La película plantea como tesis dramática la desnudez del absurdo imperante en nuestros países latinoamericanos, tomando como punto de partida el modus vivendi de los hondureños, rodeados de la miseria cultural, de la politiquería, del salvajismo, de lo bucólico, lo onírico. Esta película, incluso, bien tiene un dejo quijotesco, expuesto en el hecho de que, si existe trama, la trama es muy simple... la historia de Utopía es sólo la de dos personajes, Eduardo (Eduardo Bahr), y un vendedor (Fosi Bendeck), que buscan a un amigo por todo el país hasta que dan con la confirmación de que ha muerto... ${ }^{12}$.

Además de lo anterior, Carlos Ordóñez también distingue otros aspectos y escenas “del absurdo” que simbolizan elementos importantes de nuestra identidad y cultura política, como por ejemplo la escena de un político encerrado en un gallinero, otra escena de un pueblo hondureño donde se caga plátanos y otra más donde se exhibe el trueque de aceite de tiburón por una linterna. En general, todas estas escenas, por absurdas o irreales que parezcan a espectadores de otros contextos -como al público estadounidense o europeo-, en verdad suelen ser historias cotidianas en países como Honduras. En este sentido pues, la película Utopía linda entre esa "cinematografía del absurdo" y por supuesto con las temáticas que para esa década del setenta ya empezaban a explotar los autores del boom del "Realismo mágico" latinoamericano como Gabriel García Márquez, Carlos Fuentes y otros más.

12 Ibíd., p. 41. 
Artigo original

Hegemonia - Revista Eletrônica do Programa de Mestrado em Direitos Humanos, Cidadania e Violência/Ciência Política do Centro Universitário Unieuro

ISSN: 1809-1261

UNIEURO, Brasília, número 24, Julho a Dezembro de 2018, pp. 110-259.

\section{ILUSTRACIÓN 4}

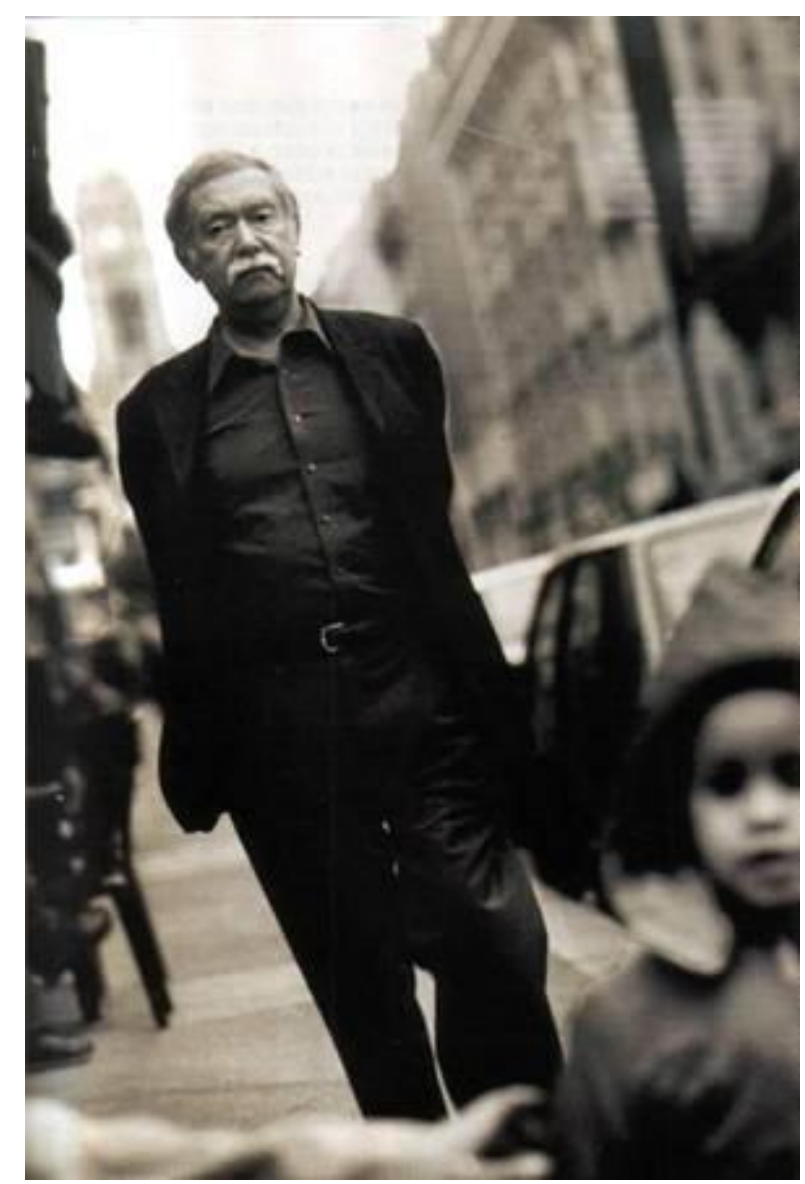

Raúl Ruíz, director de la película Utopía, paseando por París.

En todo caso, Utopía también parecía responder a un diálogo con las tendencias cinematográficas en boga en el resto de América Latina, especialmente con el llamado "Nuevo cine", una perspectiva cinematográfica de tendencia social, que proponía un cine crítico, realista, antiimperialista y revolucionario, divorciado de las prácticas monopólicas del cine de Hollywood. A este cine también se le llamó "cine de la pobreza" o "estética del hambre" según Glaubert Rocha; Julio García Espinoza lo denominó “cine imperfecto”13 y Octavio Getino y Fernando

\footnotetext{
${ }^{13}$ García Espinosa, Julio, "Por un cine imperfecto (Veinticinco años después)”, En: Revista Academia, pp. 49-54.
} 
Artigo original

Hegemonia - Revista Eletrônica do Programa de Mestrado em Direitos Humanos, Cidadania e Violência/Ciência Política do Centro Universitário Unieuro

ISSN: $1809-1261$

UNIEURO, Brasília, número 24, Julho a Dezembro de 2018, pp. 110-259.

Solanas lo llamaron "tercer cine"14, pero en general se conoció simplemente como "Nuevo cine latinoamericano".

\section{ILUSTRACIÓN 5}

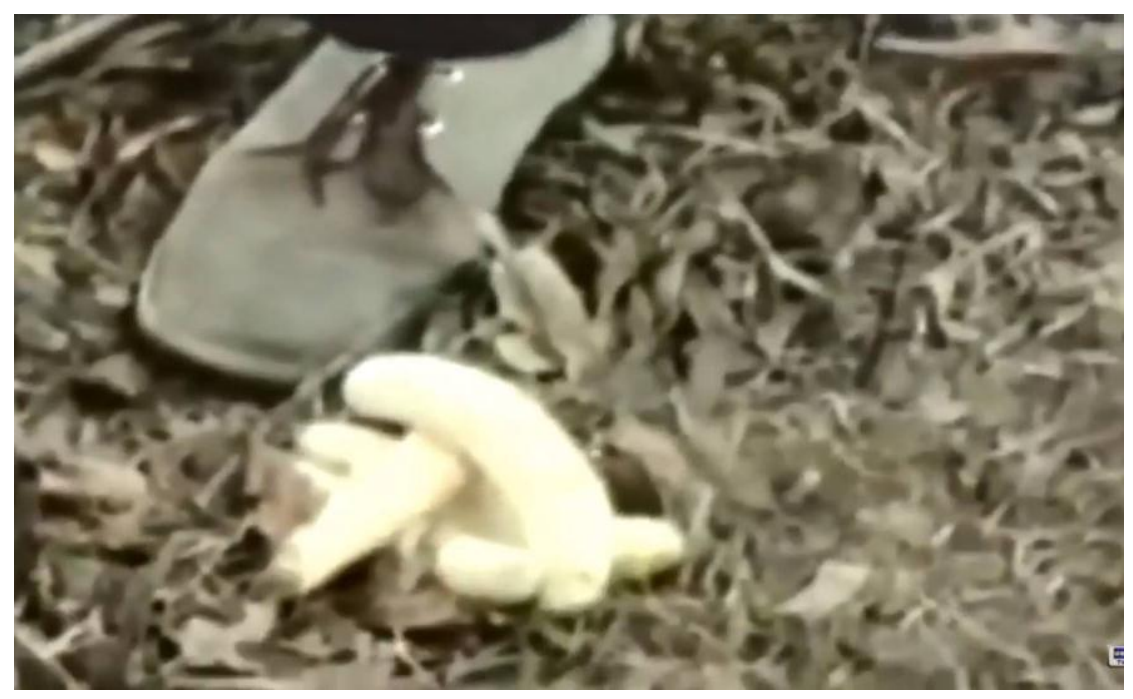

Fotograma de la película Utopía, donde se aprecia la escena del indígena hondureño defecando bananos. (Fuente: Película Utopía: www.youtube.com).

En suma, el filme Utopía, más allá de los cúmulos de facetas surrealistas planteadas en la cinta ya reiteradas por la crítica, plantea con esa escatológica escena inicial del indígena defecando bananos una abierta crítica contra la construcción discursiva peyorativa que el imperialismo norteamericano concibió para Honduras y otros países de la región al atribuirle el mote de "Banana Republic". No hay que olvidar las recientes declaraciones del presidente Donal Trump al referirse a El Salvador y otros países centroamericanos como "países de mierda". Es como si la escena dijera -parafraseando el verso del escritor hondureño Oscar Esquivel-: «De éste estiércol nacerá la flon»...

\footnotetext{
14 Getino, Octavio, Cine latinoamericano, México DF, Editorial Trillas, 1990.
} 
Artigo original

Hegemonia - Revista Eletrônica do Programa de Mestrado em Direitos Humanos, Cidadania e Violência/Ciência Política do Centro Universitário Unieuro

ISSN: 1809-1261

UNIEURO, Brasília, número 24, Julho a Dezembro de 2018, pp. 110-259.

Por otro lado, en lo que va del siglo XXI, varios procesos de carácter estructural, como la incidencia del narcotráfico, la expansión de la violencia, la entronización de las pandillas juveniles conocidas como "Maras" y la corrupción, han acentuado inestabilidad social y política que han evidenciado la fragilidad del Estado, por lo cual, varios cientistas sociales hasta afirman que Honduras es un "Estado fallido". Sin embargo, dos acontecimientos políticos han marcado de nuevo la visión de Honduras como la típica "Banana Republic". Desde luego, el primero fue el “Golpe de Estado” de 2009 contra el presidente constitucional José Manuel Zelaya Rosales; el segundo, fue el fraude electoral de noviembre de 2017, mediante el cual el oficialista y conservador Partido Nacional -liderado por el dictador Juan Orlando Hernández Alvarado, más conocido como JOH-, ejecutó un colosal fraude (reconocido por instancias como la OEA y los demás partidos de oposición) contra el virtual ganador de las elecciones, la "Alianza de Oposición contra la Dictadura”, liderada por Salvador Nasralla y el ex presidente Manuel Zelaya Rosales.

Estos dos episodios han mancillado la dignidad y la imagen del país a nivel regional e internacional, resucitando el estigma de Honduras como la típica "Banana Republic". Recientemente por ejemplo, a partir del fraude electoral, un artículo describía a Honduras como "el Jurassic Park de América Latina"15.

En suma, como afirma el Padre Melo (SJ), de nuevo se ha impuesto en Honduras la geopolítica imperial por sobre los dinamismos nacionales. De nuevo ha pesado en Honduras la lógica de la "Banana Republic". Los asuntos hondureños se definen sin el país, fuera del país y en contra del país. El Departamento de Estado y el Comando Sur decidieron cerrar filas en contra del peligro que para ellos supone un gobierno de centro-izquierda al mando de Salvador Nasralla y "Mel” Zelaya $^{16}$.

\footnotetext{
${ }^{15}$ Regalado, Roberto, Honduras: el Jurassic Park de América Latina, En: https://www.alainet.org/es/articulo/189722, (Consultado el 6 de enero del 2018).

16 Melo, Padre, Un fraude con sabor a Golpe de Estado con modalidad electoral, En: http:// radioprogresohn.net/elecciones/2017/12/30/un-fraude-con-sabor-a-golpe-de-estado-con-modalidadelectoral/, (Consultado el 6 de enero del 2018).
} 
Artigo original

Hegemonia - Revista Eletrônica do Programa de Mestrado em Direitos Humanos, Cidadania e Violência/Ciência Política do Centro Universitário Unieuro

ISSN: $1809-1261$

UNIEURO, Brasília, número 24, Julho a Dezembro de 2018, pp. 110-259.

\section{ILUSTRACIÓN 6}

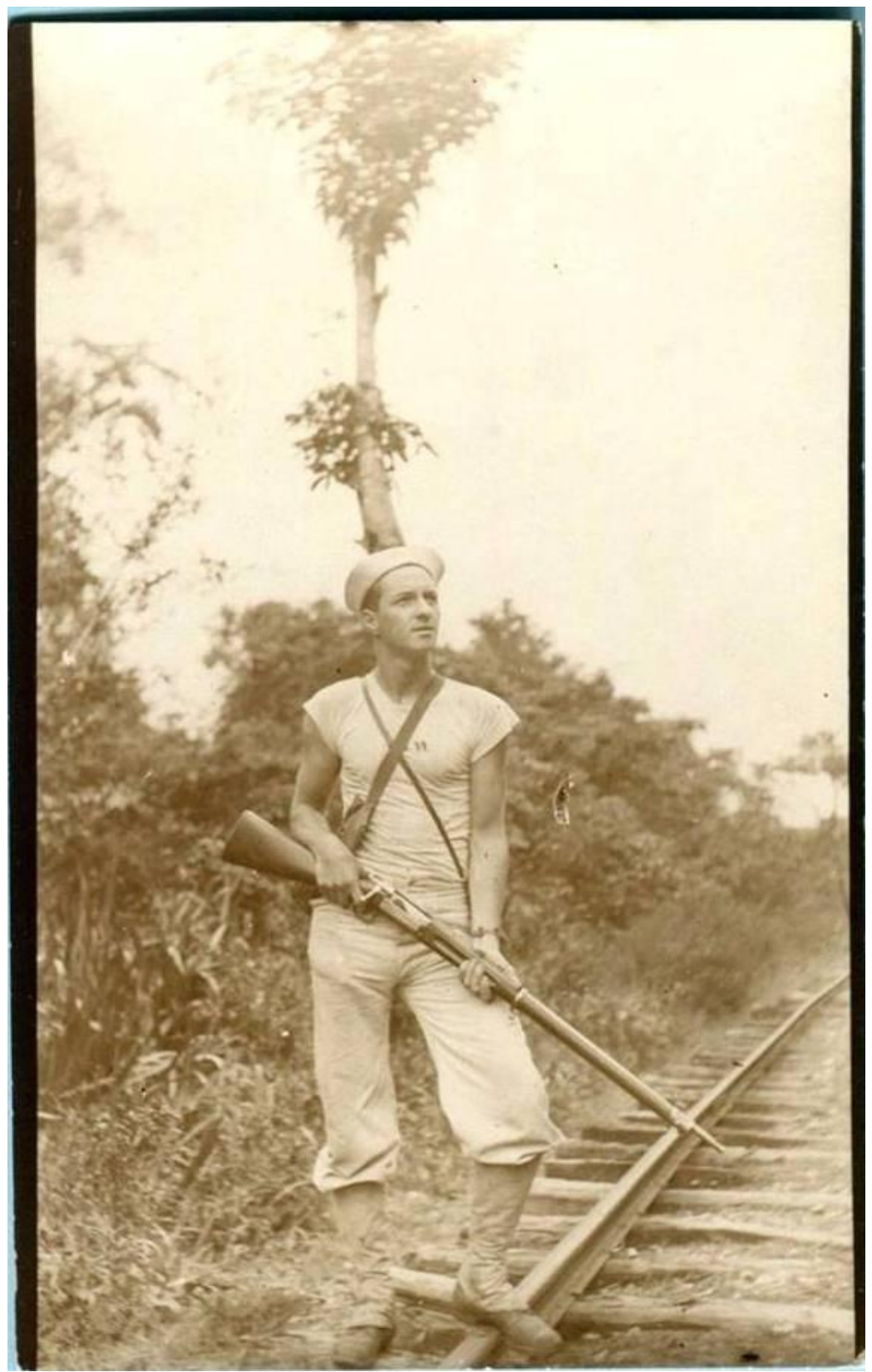

Un Marine estadounidense, apostado en la vía del tren hacia Puerto Cortés en 1911. Reiteradamente, desde esos iniciales años del siglo XX, el gobierno norteamericano enviaba misiones militares, a veces en visitas de cortesía, y en otras de atemorizamiento -con Marines y acorazados incluidos-, con la finalidad de mostrar su hegemonía militar, política y económica a nuestros países. (Archivo del poeta José González Paredes). 
Artigo original

Hegemonia - Revista Eletrônica do Programa de Mestrado em Direitos Humanos, Cidadania e Violência/Ciência Política do Centro Universitário Unieuro

ISSN: $1809-1261$

UNIEURO, Brasília, número 24, Julho a Dezembro de 2018, pp. 110-259.

3) La difusión del imaginario de la "Banana Republic" mediante Disneylandia

En los últimos años, varios cientistas sociales latinoamericanos se han dado a la tarea de estudiar y analizar la difusión de imaginarios y estereotipos sobre América Latina y los latinoamericanos difundidos por Walt Disney y su "marca" más conocida a nivel mundial: Disneylandia". En este sentido, como se verá más tarde, el propio Walt Disney visitó fugazmente Honduras, y por medio de una de sus historietas o Comic, parodió el imaginario hondureño de "Banana Republic" por antonomasia.

Uno de los medios de comunicación que más ligado ha estado a la vida de los latinoamericanos es el cine, ya que millones de personas acuden diariamente a los cines durante su tiempo de ocio. Sin embargo, al tiempo que las personas disfrutan frente a las pantallas de su tiempo libre, también llegan a conocer en ellos valores, tendencias, prácticas sociales, códigos, conductas, imágenes del mundo, etcétera. Se trata de conocimiento que en un determinado momento la audiencia puede llegar a interiorizar y poner en práctica en su vida cotidiana.

De acuerdo con los estudios culturales, los medios de comunicación masivos como la televisión o el cine transmiten una serie de mensajes hegemónicos en donde se defiende y se proyecta por encima de cualquier otra la ideología de las élites, además de que reproducen estereotipos,

${ }^{17}$ En este sentido, algunos de los estudios más relevantes sobre la influencia de los productos y personajes de Disneylandia en el mercado y consumo cultural en América Latina son los siguientes: para México: Aurrecoechea, Juan Manuel, "Paquetes de sorpresas. Disney, México y los Tres caballeros", En: Boletín Perfiles, México DF, Universidad Nacional Autónoma de México (UNAM), febrero de 2003, pp. 128-133; Maeda, Carla, "Entre princesas y brujas: Análisis de las representaciones de las protagonistas y antagonistas presentes en las películas de Walt Disney", En: Actas del III Congreso Internacional Latina de Comunicación Social (III CILCS), Monterrey, Universidad de la Laguna, 2011. Para el caso de Chile, un estudio pionero es: Purcell, Fernando, "Cine, propaganda y el mundo de Disney en Chile durante la Segunda Guerra Mundial”, En: Revista Historia, N 43, Vol. II, julio-diciembre 2010, pp. 487-522. 
Artigo original

Hegemonia - Revista Eletrônica do Programa de Mestrado em Direitos Humanos, Cidadania e Violência/Ciência Política do Centro Universitário Unieuro

ISSN: 1809-1261

UNIEURO, Brasília, número 24, Julho a Dezembro de 2018, pp. 110-259.

situación que ha sido evidenciada por algunos autores como Van Zoonen ${ }^{18}$, Espinar ${ }^{19}$, y Fandos y Martínez entre otros ${ }^{20}$.

Una de las compañías mediáticas que ha obtenido más éxito en la producción de películas dirigidas al público infantil es "Walt Disney", que ha producido cintas como Buscando a Nemo (2003), El rey león (1994), Aladdin (1994), Toy Story 2 (1999), La bella y la bestia (1991), y Monsters Inc (2001), que son obras cinematográficas ubicadas dentro del ranking de las 100 películas más taquilleras de la historia del $\operatorname{cine}^{21}$.

Entre los factores que contribuyen al gran éxito de Disney, sobresale el económico, ya que la empresa está valorada en 65,900 millones de dólares, los cuales provienen de las diversas ramas que forman el conglomerado: estudios de cine, parques temáticos, canales de televisión y "otros productos", entre los que se puede mencionar la venta de libros, revistas, comic, juegos interactivos, juguetes, productos de belleza, ropa, etcétera ${ }^{22}$.

Disney inició creando cortometrajes en donde aparecían como protagonistas algunos personajes a los que se ha denominado "animales humanoides", tal es el caso del ratón Mickey (1928), el perro Pluto (1930) y el pato Donald (1934). Sin embargo, también lanzó el primer largometraje de dibujos animados en la historia del cine, Blancanieves y los siete enanos (1937), mismo que obtuvo un gran éxito a nivel mundial ${ }^{23}$.

Las historias de Disney se han convertido además en un producto legitimado al interior de las familias a lo largo de los años, gracias a la imagen de inocencia que esta compañía vende en sus producciones $^{24}$.

Disney participa por lo tanto objetivando un mundo para la niñez, pero también para los adultos y para los países, construyendo una imagen distorsionada o estereotipada de la realidad social,

\footnotetext{
${ }^{18}$ Van Zoone, E., “The Women Movement' s and the Media: Constructing and Public Identity”, En: European Journal of Comunication, $\mathrm{N}^{\circ}$ 7, 1992, pp. 453-476.

${ }^{19}$ Espinar, E., "Estereotipos de género en los contenidos audiovisuales infantiles", En Revista Comunicar, $N^{\circ} 15$, 2007, pp. 129-135.

${ }^{20}$ Fandos, M., y Martínez M., “Estereotipos en el Comic”, En: Revista Comunicar, № 12, 1999, pp. 117-119.

21 OSCARZINE, Recuperado el 10 de abril de 2010 de Oscarzine: http://www.oscarzine.com/taquilla/top.htm

22 Maeda, Carla, "Entre princesas y brujas"... Op. cit., p. 3.

${ }^{23}$ Gubern, R., Historia del cine, Barcelona, Editorial Baber, 1995.

${ }^{24}$ Giroux, H., El Ratoncito Pérez: Disney o el fin de la inocencia, Madrid, Fundación German Sánchez Ruipérez, 2001.
} 
Artigo original

Hegemonia - Revista Eletrônica do Programa de Mestrado em Direitos Humanos, Cidadania e Violência/Ciência Política do Centro Universitário Unieuro

ISSN: 1809-1261

UNIEURO, Brasília, número 24, Julho a Dezembro de 2018, pp. 110-259.

por lo tanto es importante cuestionarse acerca de las consecuencias que ha acarreado en la construcción de imaginarios acerca de países del Tercer Mundo, y en particular de América Latina.

Efectivamente, ya desde la perspectiva de los "Estudios Culturales", se ha demostrado que en los medios masivos de comunicación no existen "mensajes inocentes", es decir, ningún texto mediático busca solamente proporcionar entretenimiento a la audiencia, sino que también transmiten estereotipos y diversos valores sociales y visiones del mundo y de la vida ${ }^{25}$.

Como afirma Carla Maeda, los contenidos manifiestos y latentes están presentes en todo tipo de mensajes mediáticos, y aunque es importante analizar los "contenidos serios", es decir los noticieros o algún tipo de programa que trate temas políticos y económicos, es aún más relevante tomar en cuenta los contenidos que tratan temas más suaves ya que a través de ellos pudieran estarse transmitiendo una gran cantidad de mensajes implícitos relacionados con los valores sociales y las actitudes básicas necesarias para interactuar sin problemas dentro de una comunidad.

Los mensajes de este tipo, están presentes, de acuerdo con los autores de esta teoría, como Dorfman y Mattelard incluso en programas tan triviales como las caricaturas de "Tom y Jerry" o "El Pato Donald", ya que aunque en apariencia son inofensivos, algunas investigaciones han encontrado que programas de este tipo transmiten la ideología dominante ${ }^{26}$.

Pero, ¿Cómo fue que Walt Disney empezó a acercarse a América Latina? La respuesta nos la explica el historiador chileno Fernando Purcell. El contexto histórico en que empezó a penetrar en la región fue el marco de la "II Guerra Mundial", cuando el gobierno de los Estados Unidos se debatía en contienda con la Alemania de Adolfo Hitler. Así, en 1941, se creó la "Motion Picture Society for the Americas" (MPSA), una sociedad instrumental creada en marzo de ese año por los distintos estudios de Hollywood y apoyada por el Departamento de Estado, con la finalidad de promover las buenas relaciones entre Estados Unidos y América Latina durante la

\footnotetext{
${ }^{25}$ Entre otros autores, puede consultarse a: Barbero, Jesús Martín, De los medios a las mediaciones: Comunicación, cultura y hegemonía, México DF, Ediciones Gili, 2ª edición, 1991; Morley, D., Televisión, Audiences and Cultural Studies, Londres, Routledge, 1992.

${ }^{26}$ Dorfman A., y Mattelard, A., Para leer al Pato Donald, México DF, Siglo XXI Editores, 1995.
} 
Artigo original

Hegemonia - Revista Eletrônica do Programa de Mestrado em Direitos Humanos, Cidadania e Violência/Ciência Política do Centro Universitário Unieuro

ISSN: 1809-1261

UNIEURO, Brasília, número 24, Julho a Dezembro de 2018, pp. 110-259.

Segunda Guerra Mundial27. La organización había sido establecida a instancias de una organización pública conocida como "Office of the Coordinator of Inter American Affairs" (OCIAA), organismo dirigido por Nelson Rockefeller, -quien también arribó a Honduras en el marco de sus funciones en ese proyecto- que funcionaba bajo la tutela del Departamento de Estado.

${ }_{27}$ Purcell, Fernando, “Cine, propaganda y el mundo de Disney en Chile...”, Op. Cit., pp. 487-488. 
Artigo original

Hegemonia - Revista Eletrônica do Programa de Mestrado em Direitos Humanos, Cidadania e Violência/Ciência Política do Centro Universitário Unieuro

ISSN: 1809-1261

UNIEURO, Brasília, número 24, Julho a Dezembro de 2018, pp. 110-259.

\section{ILUSTRACIÓN 7}

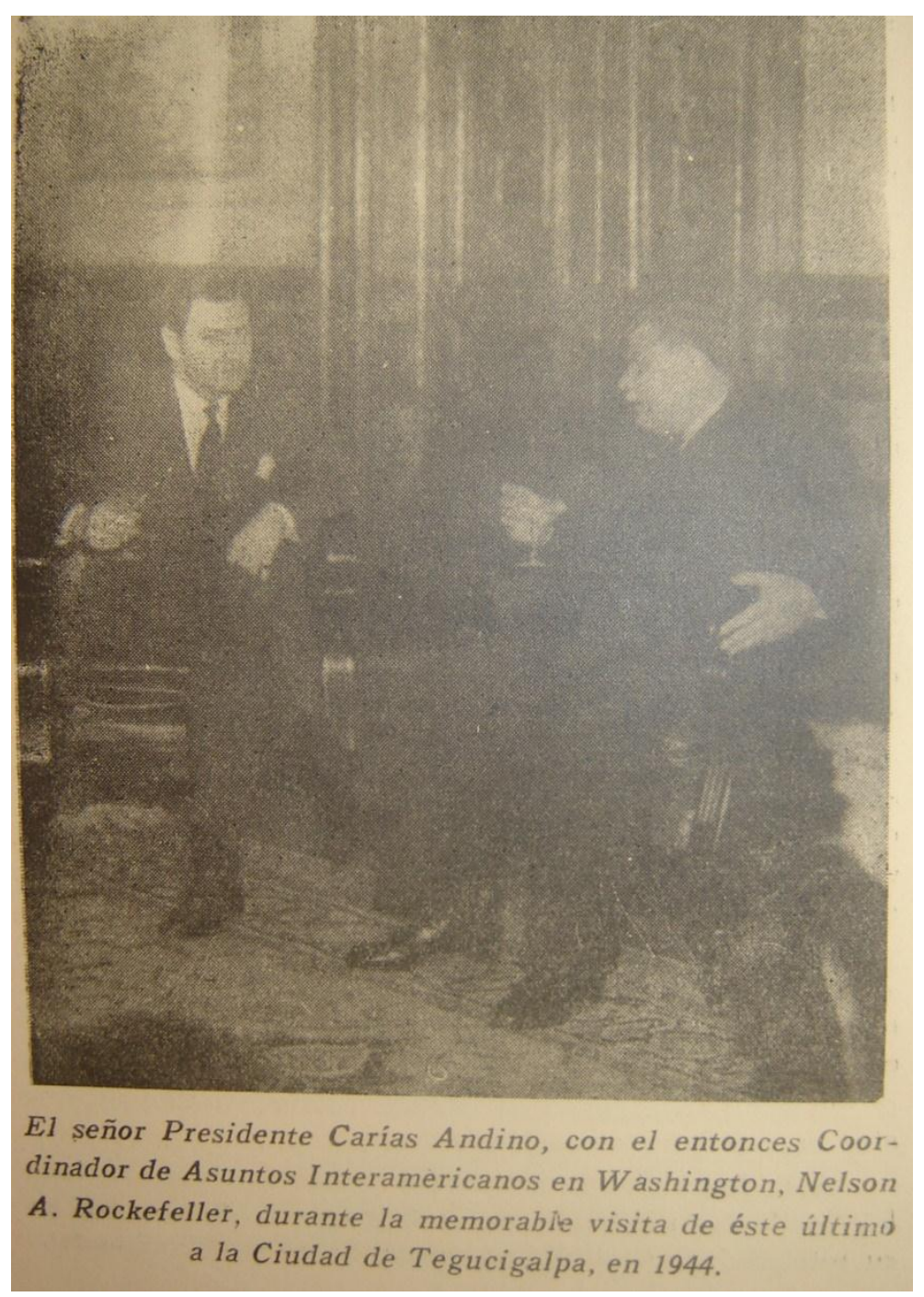

Visita de Nelson A. Rockefeller, Coordinador de Asuntos Interamericanos de Estados Unidos al presidente de Honduras, Tiburcio Carías Andino, en 1944. (Colección de Diario La Época, 1944, Hemeroteca Universitaria, UNAH).

Fue durante este grave conflicto mundial cuando la política del "Buen vecino" cobró una importancia estratégica mayor. Por ello el gobierno de Estados Unidos nombró a Nelson Rockefeller a cargo de la OCIAA, procurando que dicho organismo se encargase de articular una política de acercamiento cultural a nivel continental, lo que tenía un claro propósito 
Artigo original

Hegemonia - Revista Eletrônica do Programa de Mestrado em Direitos Humanos, Cidadania e Violência/Ciência Política do Centro Universitário Unieuro

ISSN: 1809-1261

UNIEURO, Brasília, número 24, Julho a Dezembro de 2018, pp. 110-259.

estratégico. Esta organización tuvo una serie de ámbitos de desarrollo, pero el cine ocupó un lugar privilegiado, lo que explica la creación de un departamento especializado en el tema: la "División fílmica" de la OCIAA, la cual se preocupó de censurar todo material ofensivo para Latinoamérica, evitar la distribución de películas que dieran una visión errada de la sociedad de Estados Unidos, promover la solidaridad hemisférica, producir cortometrajes que facilitaran el entendimiento interamericano y estimular la presencia de temáticas y música latinoamericana en las producciones hollywoodenses.

John Hay Whitney, quien había sido productor ejecutivo de la película "Lo que el viento se llevó", fue el primer encargado de la división fílmica de la OCIAA, puesto que ocupó hasta 1942, cuando pasó al área de inteligencia en la Fuerza Aérea, siendo reemplazado en junio de 1942 por Francis Alstock. Whitney se embarcó en un proyecto que buscaba esparcir los mensajes de libertad y democracia a todos los países latinoamericanos, el cual tenía un claro tenor propagandístico que no fue dirigido al público latinoamericano solamente, sino también al estadounidense. El desafío era mostrar películas sobre Estados Unidos y su gente a los habitantes de las repúblicas latinoamericanas, así como exhibir filmes de las actividades y experiencias de vida latinoamericanas en Estados Unidos. Este último punto era sensible, debido al predominio de ideas negativas sobre la región en el país del norte. El mejor ejemplo es el de una encuesta realizada en 1940, donde se pidió a ciudadanos estadounidenses escoger un número ilimitado de características de los habitantes de América Latina mencionadas espontáneamente, lo que explica que los porcentajes sumados, superaran el 100\%. Solo un 5\% de los encuestados consideró que los latinoamericanos eran "eficientes" y un 13\% que eran "honestos". Si bien es cierto las cifras se elevaban para considerarlos "imaginativos", alcanzando un 23\%, lo que prevaleció entre el 80\% de los consultados fue su característica racial: "de piel oscura". A esto se agrega el hecho de que un 41\% de las personas consultadas los consideraban "flojos" y un 47\% "emocionales". No es de extrañar entonces que la OCIAA intentara concentrar parte importante de sus esfuerzos en transformar las nociones que la sociedad estadounidense tenía sobre América Latina, utilizando el cine como herramienta privilegiada para aquello. Sin embargo, los 
Artigo original

Hegemonia - Revista Eletrônica do Programa de Mestrado em Direitos Humanos, Cidadania e Violência/Ciência Política do Centro Universitário Unieuro

ISSN: 1809-1261

UNIEURO, Brasília, número 24, Julho a Dezembro de 2018, pp. 110-259.

principales esfuerzos estuvieron direccionados a promover una imagen favorable de Estados Unidos en la región ${ }^{28}$.

Fue en este marco que Walt Disney comenzó a producir filmes propagandísticos, en asociación con entidades gubernamentales de Estados Unidos y Canadá, desde antes de diciembre de 1941, fecha en que Estados Unidos entró directamente al conflicto de la Segunda Guerra Mundial. Entre 1941 y 1946 los estudios Disney produjeron 28 "filmes educacionales", como se los denominaba, y 80 destinados al entrenamiento militar, además de 6 grandes producciones para la industria del entretenimiento. A esto hay que agregar la impresionante suma de 70 cortometrajes, de los cuales 6 fueron nominados al Oscar y dos lo obtuvieron (Der Fuhrer's Face y Lend a Paw). Cabe destacar que varias de las producciones destinadas a las salas de espectáculo fueron a la vez proyectos de propaganda producidos en conjunto con agencias gubernamentales, como es el caso de 3 de los 6 largometrajes estrenados durante la guerra: "Victory Through Air Power", "Saludos Amigos” y “Three Caballeros". Llaman la atención las últimas dos películas, por cuanto sus temáticas, así como varios de sus personajes, son latinoamericanos, lo que revela el grado de importancia que el gobierno y la industria fílmica le asignaron a América Latina durante el prolongado conflicto, con la finalidad de fortalecer, a través del cine, una solidaridad hemisférica que resultaba esencial en el contexto de un enfrentamiento que adquirió ribetes globales.

El propio Walt Disney viajó por lo tanto a América Latina en 1941, liderando un grupo de 18 personas, entre los que estaban el encargado de negocios John C. Rose, el director musical Charles Wolcott y varios dibujantes, productores y técnicos. El viaje del técnico en filmaciones John Walter Cutting a Brasil, que se inició el 6 de agosto de 1941 desde Miami, fue el inicio de un proyecto de gira que se prolongó hasta el miércoles 22 de octubre, con la llegada de los últimos profesionales de los estudios Disney de regreso a Estados Unidos. El equipo desarrolló actividades de producción y visitas en Brasil, Uruguay, Argentina, Chile, Bolivia, Perú, Ecuador,

${ }^{28}$ Ibíd., p. 493. 
Artigo original

Hegemonia - Revista Eletrônica do Programa de Mestrado em Direitos Humanos, Cidadania e Violência/Ciência Política do Centro Universitário Unieuro

ISSN: 1809-1261

UNIEURO, Brasília, número 24, Julho a Dezembro de 2018, pp. 110-259.

Colombia, Panamá, Guatemala, Honduras y México, en lo que se constituyó como el proyecto emblemático de Walt Disney durante la Segunda Guerra Mundial ${ }^{29}$.

En el caso de su estadía en Honduras, el "Diario El País" de Madrid dio cuenta de la visita de Walt Disney a Honduras ${ }^{30}$, con el fin de buscar parajes naturales para representarlos en sus películas. El creador de dibujos animados más famoso del mundo, al parecer particularmente se admiró de la catarata de Pulhapanzak, en las cercanías del Lago de Yojoa, una de las bellezas naturales del país.

Según esta nota del "Diario El País", esta joya natural ubicada en el departamento de Cortés, en las cercanías de la zona bananera, es la que aparecería en la película de Disney "El Libro de la Selva", la segunda película más comercial de Disney desde los tiempos de "Blancanieves".

Según la nota del "Diario El País", en la que se entrevista a Juli Capella, un prestigiado diseñador y arquitecto barcelonés, que cuenta su visita a Honduras hecha en 2006, el artista catalán manifiesta que Walt Disney habría viajado hasta Honduras para dibujar personalmente la catarata de Pulhapanzak y plasmarla después en "El Libro de la Selva", que por cierto no pudo ver porque falleció antes (1966) de su llegada a la pantalla grande (en 1967). El Libro de la Selva, también conocido como El Libro de las Tierras Vírgenes, fue escrito por el poeta y escritor hindú de origen británico Rudyard Kipling entre 1894 y 1895.

\footnotetext{
29 Ibíd., p. 510.

${ }^{30}$ Diario El País, Braun, Andrés, "La Catarata hondureña que inspiró a Walt Disney", Madrid, Sección El Viajero, sábado 13 de septiembre de 2008. También véase: Honduras is Great, Pulhapanzak inspiró a Walt Disney en "El Libro de la Selva”, tomado de: https://hondurasisgreat.com/pulhapanzak-walt-disney/, consultado el 1 de diciembre del 2017.
} 
Artigo original

Hegemonia - Revista Eletrônica do Programa de Mestrado em Direitos Humanos, Cidadania e Violência/Ciência Política do Centro Universitário Unieuro

ISSN: 1809-1261

UNIEURO, Brasília, número 24, Julho a Dezembro de 2018, pp. 110-259.

\section{ILUSTRACIÓN 8}

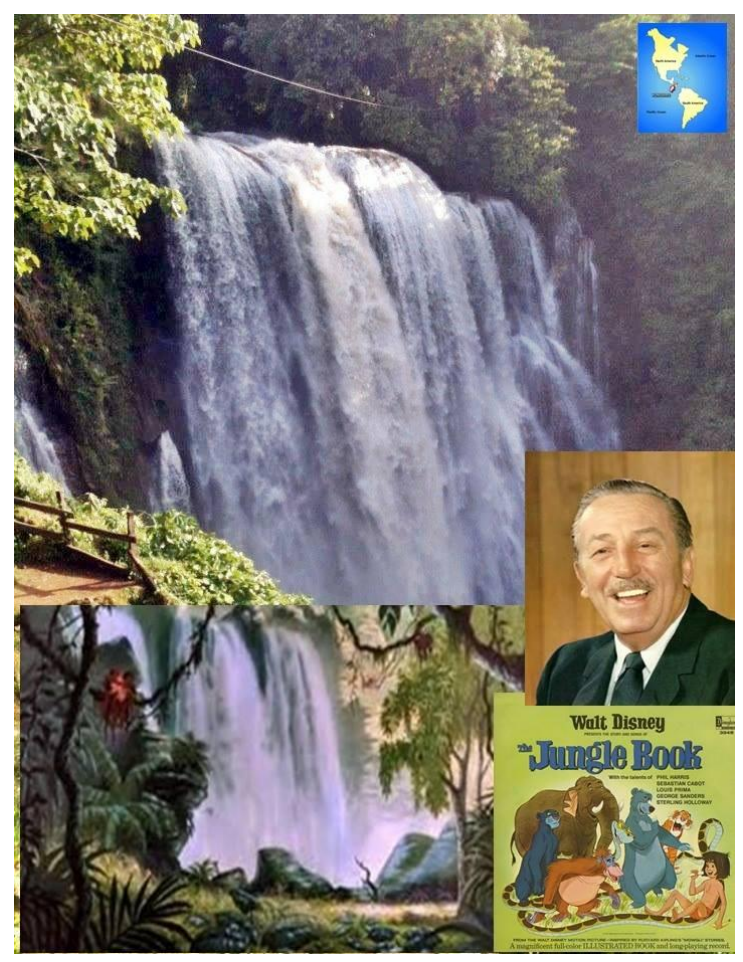

Estampas tomadas de la página de Facebook "Honduras is Great", donde se aprecia la catarata de Pulhapanzak en Honduras, y abajo, el recuadro de la Catarata representada en la película "El Libro de la Selva", de los Estudios

"Walt Disney".

Según Juli Capella, Walt Disney “era muy minucioso al documentarse, y por eso viajó hasta aquí para dibujar personalmente esta catarata que luego apareció en El libro de la selva".

Sin embargo, el hito más relevante de Walt Disney en la construcción de un imaginario discursivo sobre Honduras como emblemática "Banana Republic" lo difundió a través de la publicación de un número de "Comic" o "pasquín" como le llaman en Centroamérica, nada más y nada menos que en una de las historietas del famoso "Pato Donald".

Efectivamente, en los años sesenta, Walt Disney publicó una famosa historieta del Pato Donald denominada "Donald Duck: secret of Hondorica", más tarde publicada en español como "El Secreto de Hondorica". 
Artigo original

Hegemonia - Revista Eletrônica do Programa de Mestrado em Direitos Humanos, Cidadania e Violência/Ciência Política do Centro Universitário Unieuro

ISSN: $1809-1261$

UNIEURO, Brasília, número 24, Julho a Dezembro de 2018, pp. 110-259.

\section{ILUSTRACIÓN 9}

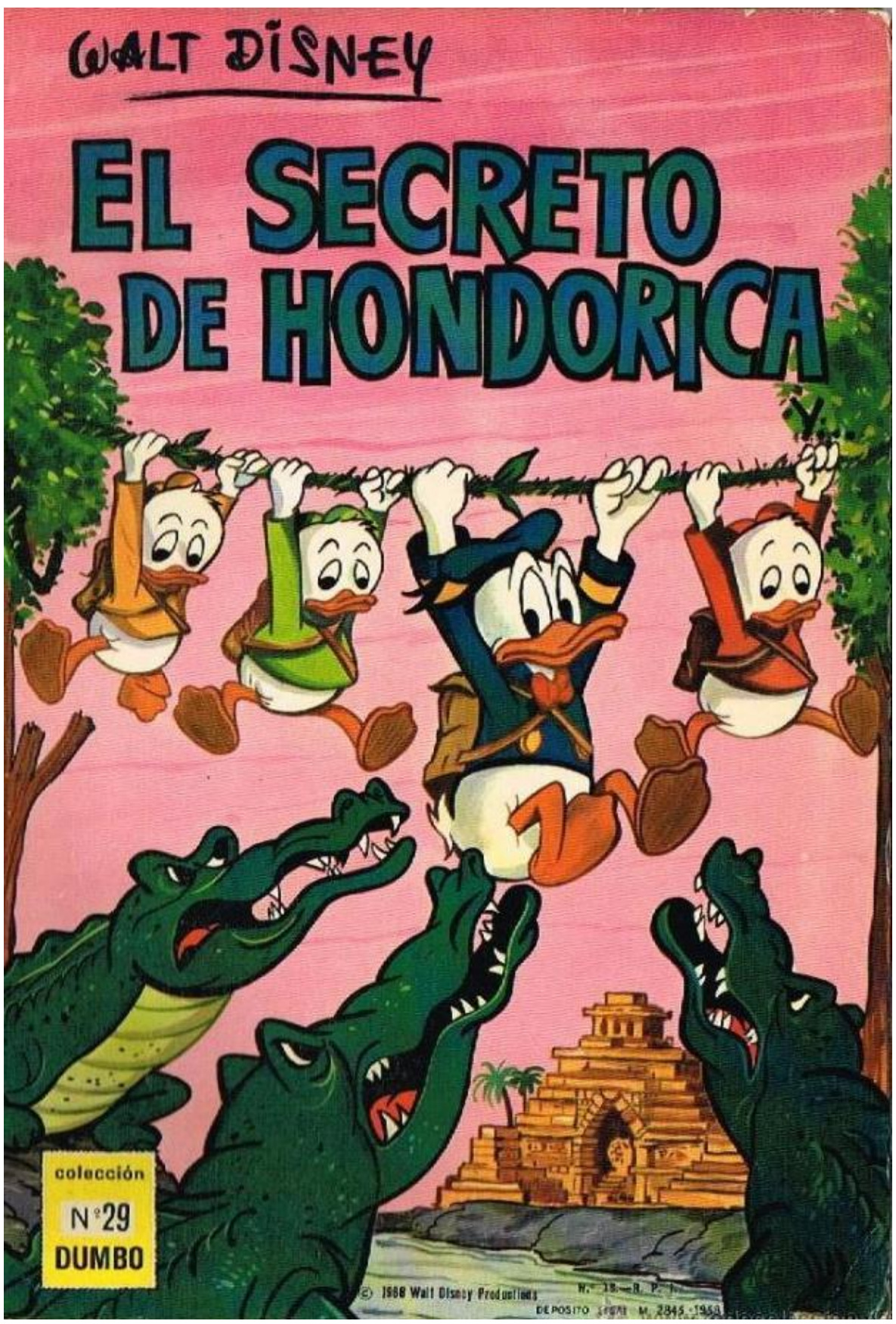

Portada en español de "El secreto de Hondorica", Barcelona, Colección Dumbo, N²9, 1964. Como se ve, la imagen denota inmediatamente una representación primitiva y bárbara del paisaje hondureño, rodeado de ruinas prehispánicas, y de fieras y tribus selváticas que ponen en peligro al Pato Donald y sus aventureros sobrinos. La típica imagen de la "Banana Republic". 
Artigo original

Hegemonia - Revista Eletrônica do Programa de Mestrado em Direitos Humanos, Cidadania e Violência/Ciência Política do Centro Universitário Unieuro

ISSN: 1809-1261

UNIEURO, Brasília, número 24, Julho a Dezembro de 2018, pp. 110-259.

Desde las primeras páginas del Comic se perciben los estereotipos e imágenes negativas y salvajes sobre los habitantes de Hondorica (es decir de los hondureños). Desde luego, en la primera gráfica, el Tío Mc Pato llama al Pato Donald y sus sobrinitos, y mostrándoles un mapa (en donde a todas señas se visualiza Honduras y Centroamérica), comienzan el diálogo. El Pato Donald, junto con sus sobrinos, le increpa:

-Para que nos has llamado si puede saberse, Tío Gilito?-

Tío Mc Pato les contesta:

-Tengo un trabajito para vosotros, Hijo. ¡Quiero que vayáis a un recado ahí, a Hondorica!-.

Y luego añade: -Se ha estrellado uno de mis aviones correos en el sitio marcado con una "X". Necesito que busquéis los restos y recuperéis unos papeles de mucho valor-.

Y perplejo, el Pato Donald le contesta: -Pero eso ni siquiera aparece en el mapa. ¡Es una zona sin civilizar!-.

Y luego añade: ¿¿Quieres que nos metamos en esa selva salvaje para buscar unos papeles viejos y a lo mejor mojados?-.

Y finalmente, los niños rematan diciendo: ¿¿Y qué nos dices de los salvajes?. ¿Nos atacarán?-.

A todas luces, estos pequeños diálogos nos inducen a ver una serie de estereotipos de carácter negativos pero muy tradicionales sobre las típicas "Banana Republic", las cuales, según el imaginario de los países anglosajones, están habitadas por bárbaros, por tribus salvajes, por paisajes selváticos abarrotados de fieras y de peligros, en suma, son países bárbaros e incivilizados a los cuales hay que domeñar y apropiar. La dicotomía e ideal imperialista entre civilización versus barbarie. 
Artigo original

Hegemonia - Revista Eletrônica do Programa de Mestrado em Direitos Humanos, Cidadania e Violência/Ciência Política do Centro Universitário Unieuro

ISSN: $1809-1261$

UNIEURO, Brasília, número 24, Julho a Dezembro de 2018, pp. 110-259.

\section{ILUSTRACIÓN 10}

EL JECERT QF HOHOOSRCA R. 27
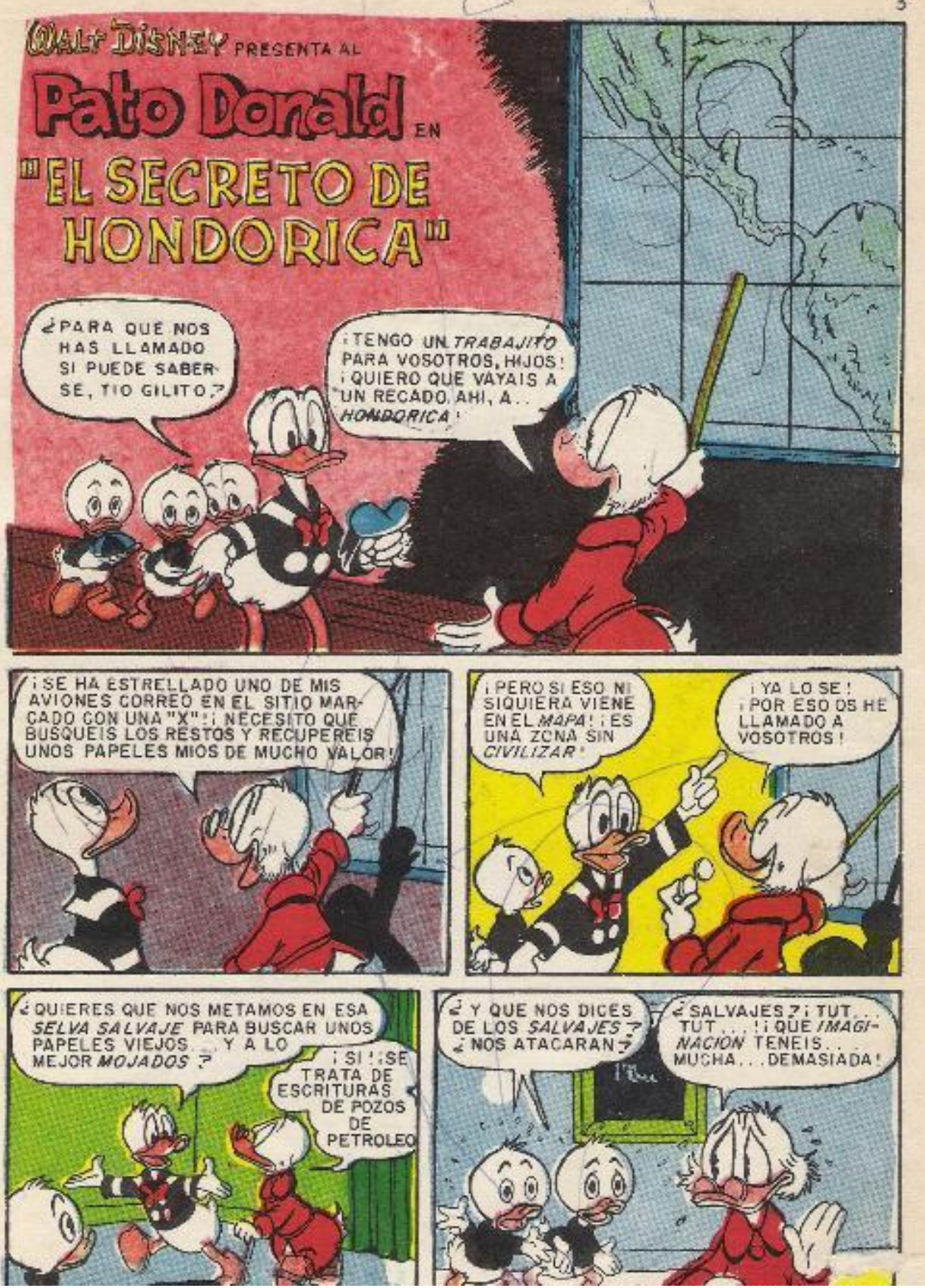

Primera página de la Historieta "Pato Donald en el secreto de Hondorica". 
Artigo original

Hegemonia - Revista Eletrônica do Programa de Mestrado em Direitos Humanos, Cidadania e Violência/Ciência Política do Centro Universitário Unieuro

ISSN: 1809-1261

UNIEURO, Brasília, número 24, Julho a Dezembro de 2018, pp. 110-259.

Julio Escoto estudió estas y otras representaciones de la "Banana Republic" en un artículo reciente $^{31}$, y nos argumenta que en estas historietas, Walt Disney nos retrata las historietas del Pato Donald, sus sobrinos y amigos, en una tierra exótica llamada "Hondorica" (deformación de la palabra Honduras); Hondorica queda al Este de San Banador, al Norte de Inca Blinca y no lejos de Brutonia.

Esta tierra es un paraíso cómico donde unos desorientados campesinos le dan la bienvenida al Pato Donald y sus tres bonitos sobrinos, así como graciosamente les entregan todos los tesoros que no supieron valorar. De este modo, Hondorica representa, en cuanto tal, una síntesis del concepto que los extranjeros tienen acerca de Centroamérica, y particularmente de Honduras, como epitome de la "Banana Republic".

En dicha tierra de Hondorica, las personas son como infantes a los que hay que enseñar el modo de operar en el mundo moderno y para lo que el Pato Donald luce ser la persona perfecta. En sus aventuras, el Pato Donald lleva pastillas de jabón a los desaseados hondoricas y "los salva del error" de la revolución, por lo cual acepta que le regalen lingotes de oro y bananas. Le enseña a los reyes cómo gobernar y a sus súbditos cómo obedecer. El niño de una ciudad norteamericana -Donald- es mucho más sabio que cualquiera de los habitantes de Hondorica.

Si esta caricatura de Honduras como "Hondorica" fuera un ejemplo aislado de las actitudes estadounidenses con respecto a América Latina o de Honduras, en realidad es mucho más que un chiste; en gran medida, es el imaginario que aún hoy en día tienen los norteamericanos y europeos de nuestros países. En realidad, este es sólo un caso de una serie de retratos o representaciones que han determinado no sólo cómo los extranjeros ven a Honduras, sino incluso cómo los hondureños se ven a sí mismos ${ }^{32}$.

\footnotetext{
31 Escoto, Julio, “Con ajenos ojos”, En: Revista Imaginación, San Pedro Sula, Centro Editorial, Etapa III, N 7, 2016, pp. $74-82$.

32 Ibíd., p. 74.
} 
Artigo original

Hegemonia - Revista Eletrônica do Programa de Mestrado em Direitos Humanos, Cidadania e Violência/Ciência Política do Centro Universitário Unieuro

ISSN: 1809-1261

UNIEURO, Brasília, número 24, Julho a Dezembro de 2018, pp. 110-259.

Efectivamente, en un país que carece de una cultura fuerte que le sirva de defensa, esta clase de "cultura de la denigración" es peligrosa pues tiende a volverse dominante. Y la fórmula para denigrar no es exclusiva de los pasquines, ya que también se repite en novelas, en libros de viajes, documentales, noticiarios, etcétera.

El paroxismo de este imaginario se materializó hace pocos años en una remota municipalidad del Departamento de Olancho, en el oriente de Honduras, donde las autoridades del municipio de Concordia construyeron el nuevo edificio de la municipalidad con un diseño que emula a "Disneylandia", tal como se ve en la siguiente ilustración:

\section{ILUSTRACIÓN 11}

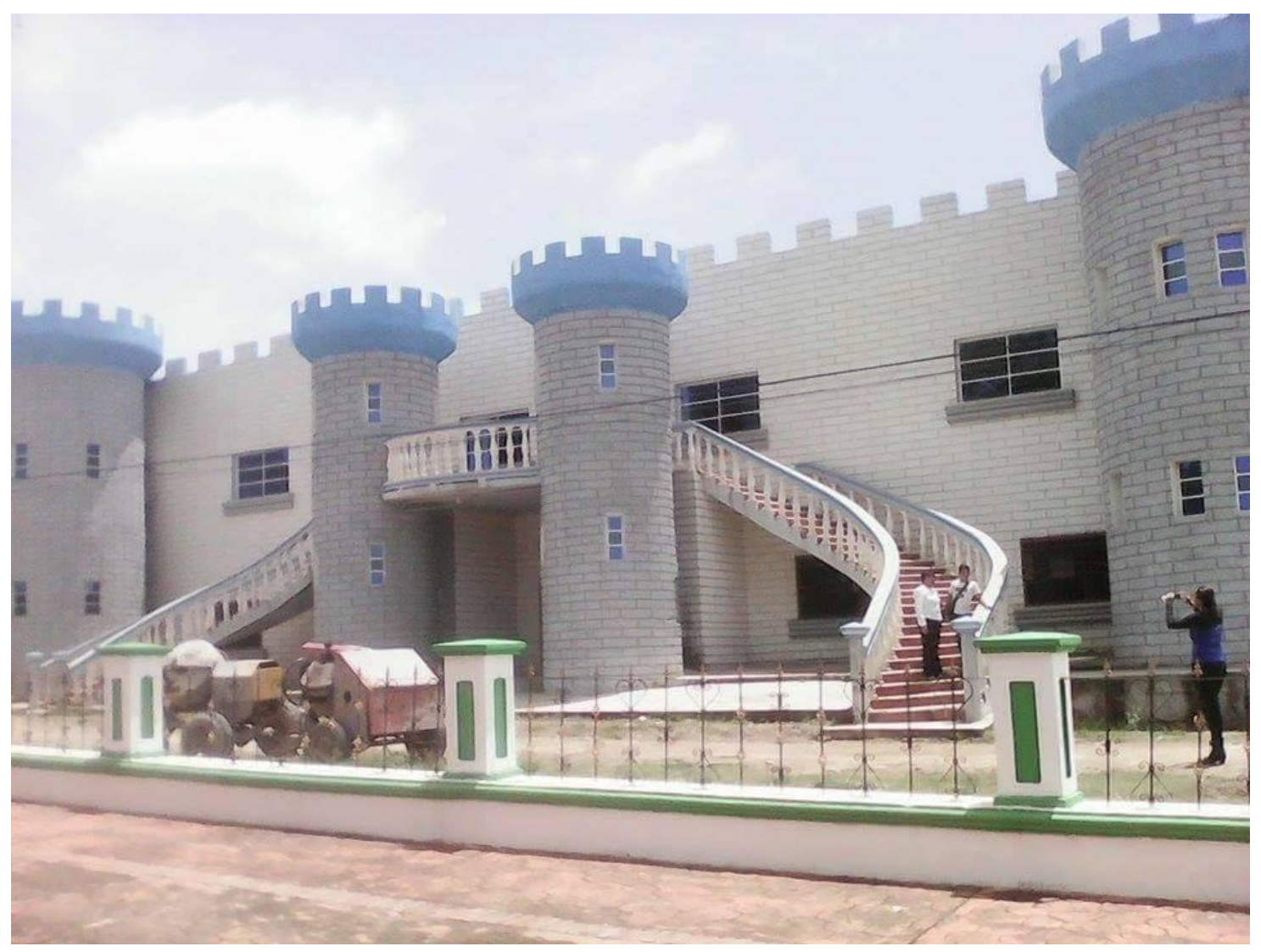

Fachada del edificio municipal de Concordia, Olancho, inspirada en el parque de atracciones de "Disneylandia".

(Foto descargada de la página de Facebook Honduras exaltada). 
Artigo original

Hegemonia - Revista Eletrônica do Programa de Mestrado em Direitos Humanos, Cidadania e Violência/Ciência Política do Centro Universitário Unieuro

ISSN: 1809-1261

UNIEURO, Brasília, número 24, Julho a Dezembro de 2018, pp. 110-259.

De este modo, comercialismo y comedia han distorsionado por lo tanto la percepción de Honduras y como resultado los hondureños se han convertido en víctimas de un "imperialismo cultural" semejante al denunciado por Franz Fanon. Todo pueblo colonizado -en otras palabras, cada gente en cuya alma ha sido cultivado un complejo de inferioridad que ocasiona la muerte de su propia cultura original- se encuentra a sí mismo, cara a cara, ante el lenguaje de la "nación civilizada", esto es con la cultura de la "madre patria". Y al colonizado se le extrae de su estatus de jungla sólo en proporción y según lo que adopte de los estándares de la "madre patria". De esta manera, esa ha sido la función de estos "repertorios discursivos" como los Comic o las películas de dibujos animados: intentar crear una "caricatura estereotipada" de nuestros pueblos que intente imponer la hegemonía cultural de los países imperialistas sobre nuestros pueblos y culturas.

\section{4) El Enclave Minero}

A continuación presentaremos brevemente el desarrollo histórico de los enclaves en Honduras y cómo su naturaleza, su dinámica histórica y su hegemonía en el país inspiraron la divulgación de un "imaginario bananero de la cultura hondureña" a través de las tarjetas postales.

La Reforma Liberal de Marco Aurelio Soto y Ramón Rosa de 1876 pretendió desarrollar una economía capitalista con énfasis en la agricultura. A ese efecto, el decreto para el fomento de la "Industria Agrícola" del 29 de abril de 1877 había marcado el inicio de una política para fomentar la producción cafetalera que tanto éxito había tenido en los demás países del área, así como de otros productos como caña de azúcar, cacao, añil y el banano. A pesar de lo anterior, en Honduras el cultivo del café no fructificó, a tal grado que en 1888 el café apenas representó el $0,5 \%$ del total de exportaciones del país.

De hecho con el fracaso del café, la producción minera pasó a ser el eje del proyecto económico hondureño. Los marcos legales para su explotación fueron plasmados en el Código de Minería, redactado en 1880 por el Gobierno de Soto. Desde 1878, el propio presidente entró en contacto con el empresario neoyorquino Washington Valentine con el propósito de fundar "La Rosario 
Artigo original

Hegemonia - Revista Eletrônica do Programa de Mestrado em Direitos Humanos, Cidadania e Violência/Ciência Política do Centro Universitário Unieuro

ISSN: 1809-1261

UNIEURO, Brasília, número 24, Julho a Dezembro de 2018, pp. 110-259.

Mining Company", constituida el 2 de diciembre de 1879 para explotar, por medio de una concesión el mineral de San Juancito, comenzando la extracción de minerales en el año de $1880^{33}$.

Tanto el presidente Soto como sus sucesores en la presidencia concibieron la estricta necesidad de estructurar un marco jurídico que facilitara la inversión de capitales extranjeros en la minería hondureña, debido a la carestía de capitales en el país, así como la falta de visión empresarial de las élites nacionales, por ello, los estadistas liberales establecieron una serie de concesiones por medio de las cuales las compañías extranjeras recibirían una serie de privilegios y facilidades para establecer sus capitales en el país.

De esa forma, el presidente Soto argumentará en 1883 que "las compañías extranjeras establecidas (Rosario Mining Company) demostrarán que con capitales suficientes, científica explotación, trabajo y perseverancia, el laboreo de las minas en la república puede dar todos los provechos de una gran industria nacional. Conocida por el extranjero... la riqueza mineral... espontáneamente Honduras recibirá una corriente fecunda de progreso y civilización...”. Justamente estas dos últimas palabras (progreso y civilización), son de las ideas centrales que intentaron ser explotadas y divulgadas a través de las tarjetas postales.

Un aspecto interesante en este proceso es que la economía minera, y como veremos más adelante, también la bananera, se desarrollaron a manera de "enclave" en el país. De ahí que las postales que se generaron en el marco y contexto de este proceso son bien interesantes porque perfilaron una parte de la historia contemporánea muy relevante para el país, pero también porque difundieron una imagen bastante estereotipada, y hasta cierto punto ubicua de este tema, pues de manera abrumadora, Honduras fue auto-representada -y vista por los extranjeros- como una típica "Banana Republic".

Por otro lado, a pesar que el presidente Soto y su ministro de guerra, Enrique Gutiérrez eran socios minoritarios de la "Rosario Mining Company", estos posteriormente vendieron sus

\footnotetext{
33 Taracena Ariola, Arturo, "Liberalismo y poder político en Centroamérica (1870-1929)", En: Historia General de Centroamérica, Madrid, FLACSO, Ediciones Siruela, p. 192.
} 
Artigo original

Hegemonia - Revista Eletrônica do Programa de Mestrado em Direitos Humanos, Cidadania e Violência/Ciência Política do Centro Universitário Unieuro

ISSN: 1809-1261

UNIEURO, Brasília, número 24, Julho a Dezembro de 2018, pp. 110-259.

acciones a la compañía, con lo cual, la explotación minera en el país quedó dominada totalmente por el capital norteamericano. Este hecho puede justificar en parte el actual subdesarrollo y atraso del país en relación a los demás países del área, ya que mientras en Honduras el capital norteamericano dominó por completo la inversión capitalista en el país, en los demás países de la región se fue constituyendo una burguesía nacional cafetalera desde ese tiempo. Por ello al no generarse una burguesía minera nacional, las élites económicas del país no pudieron competir nunca con la inversión extranjera. Las extraordinarias condiciones de las concesiones otorgadas a la "Rosario Mining Company" por parte del Estado de Honduras determinaron que muy poco de la riqueza productiva quedara en el país.

Los privilegios otorgados a la Rosario Mining Company en materia de exoneración de impuestos, franquicias aduaneras por importación de maquinaria y equipo, le permiten una rápida capitalización, recuperación de inversiones y considerables ganancias. En los 10 años siguientes a la obtención de su primera concesión logró un valor acumulado de $\$ 3,000,000$ en la producción de oro y plata. El auge de la minería fue extraordinariamente importante para el país en las 2 décadas finales del siglo XIX, donde representó un promedio del 50\% del total de exportaciones del país, es decir, la mitad del total de exportaciones del país estaba en manos de una sola empresa extranjera ${ }^{34}$.

A principios del siglo XX, se produjo un declive de los precios de los minerales en el mercado mundial debido a la abundante producción mundial y el abandono en la mayor parte de países del sistema monetario basado en la plata, los cuales adoptaron el patrón oro. Todos estos factores afectaron en su conjunto y de manera muy sensible el ritmo de crecimiento del sector minero en Honduras.

En cambio, desde la última década del siglo XIX, comenzaba a tener importancia en la costa norte de Honduras la producción en gran escala del banano. Estas tendencias del decaimiento de la minería y el auge de la agricultura eran ya claramente percibidas por los mismos liberales. Así Adolfo Zúñiga, un colaborador del presidente Luis Bográn le indicaba a éste en 1887: "...Me

34 Arancibia, Juan, Honduras: Un Estado nacional?, Tegucigalpa, Editorial Guaymuras, Colección Códices, $1^{\mathrm{a}}$ reimpresión, 1988, p. 35. 
Artigo original

Hegemonia - Revista Eletrônica do Programa de Mestrado em Direitos Humanos, Cidadania e Violência/Ciência Política do Centro Universitário Unieuro

ISSN: 1809-1261

UNIEURO, Brasília, número 24, Julho a Dezembro de 2018, pp. 110-259.

he convencido que estas tierras [la costa norte], son un tesoro más valioso que nuestras montañas minerales. Todo el arte consiste en no echar por la ventana ese tesoro" ${ }^{35}$.

En efecto, ya para principios del siglo XX la minería hondureña presentaba signos de su virtual estancamiento, mientras el sector agrícola, a través de la producción bananera en la costa norte comenzaba a convertirse en el nuevo eje de la economía primaria exportadora. Así, para el año de 1902 las exportaciones bananeras superaron por primera vez a las exportaciones mineras, las cuales desde 1880 hasta 1901 siempre habían representado un promedio del 50\% de exportaciones del país.

A partir de este momento y hasta hace pocas décadas, el banano constituyó el principal producto de exportación del país. En suma debemos expresar que el efecto de la minería dejó poco resultado positivo para el país, ya que a través del régimen concesionario se otorgó un sin fin de privilegios a la "Rosario Mining Company", eximiéndola del pago de todo impuesto establecido, por establecerse sobre su capital, sobre sus rentas y sobre sus propiedades, así como el privilegio de importar libre de todo gravamen, su maquinaria y materiales necesarios para su funcionamiento. El país a cambio, percibió una raquítica cantidad en concepto de impuestos, los cuales nunca dinamizaron el aparato económico nacional. Quizá de los pocos beneficios para los sectores sociales hondureños lo constituyó el hecho de la creación de fuentes de trabajo que generó la actividad productiva de la compañía minera, la cual, casi siempre osciló entre 1000 y 1500 personas.

Todos estos factores permitieron que a pesar del declive minero mundial a principios del siglo XX, la "Rosario Mining Company" continuara con la explotación de la mina de San Juancito hasta 1954, cuando ya prácticamente se había agotado la capacidad productiva de la mina, no sin antes haber iniciado en 1948 la explotación de un nuevo mineral en El Mochito, departamento de Santa Bárbara, al noroccidente del país.

${ }^{35}$ Murga Frassinetti, Antonio, Enclave y sociedad en Honduras, Tegucigalpa, Editorial Universitaria, 1985, p. 46. 
Artigo original

Hegemonia - Revista Eletrônica do Programa de Mestrado em Direitos Humanos, Cidadania e Violência/Ciência Política do Centro Universitário Unieuro

ISSN: 1809-1261

UNIEURO, Brasília, número 24, Julho a Dezembro de 2018, pp. 110-259.

En el caso de las postales del "enclave minero", presentamos solamente unas pocas, en vista que la mayoría de postales del enclave que recolectamos son más bien del "enclave bananero"; sin embargo, se podría decir que hay unas constantes o tópicos representados en estas postales del centro minero de la "Rosario Mining Company" en la comunidad de San Juancito. El primero es que las postales denotan la figura recurrente de representar el entorno del cerro de San Juancito atestado de las edificaciones que albergaban las oficinas administrativas del mineral, así como el conglomerado de casas que fueron configurando el poblado en donde arrancó la primera gran empresa capitalista de Honduras, conocido como "El Rosario" o "Mina de San Juancito". Con ello, se pretendía expresar el progreso y desarrollo que el país adquiría con la inversión extranjera. Es llamativo que estas fotos sean de tipo "panorámico", con el fin de resaltar todo el paisaje y espacio que la empresa iba "conquistando" a la montaña; asimismo, es interesante que en dichas postales "no aparezcan personas", ni los obreros (una nueva clase social surgida del enclave), ni tampoco los funcionarios norteamericanos; en este caso, la idea de visualizar monumentalmente el poblado minero era el objetivo fundamental de las postales, para denotar la llegada del progreso y la Modernidad. En segundo lugar, en las postales se puede apreciar alguna maquinaria moderna utilizada para la actividad minera, procedente del equipo importado por la empresa desde Estados Unidos, que remitía inmediatamente la idea de que se estaban introduciendo los elementos tecnológicos de la era de la "Revolución Industrial", y con ello, el sistema capitalista de producción.

\section{5) El Enclave Bananero}

El desarrollo del enclave bananero en Honduras ligó de manera definitiva al país al comercio capitalista internacional a principios del siglo XX, proceso que coincidió con la transición a una fase superior del capitalismo determinado por el aparecimiento del capital monopolista. Por otro lado, hacia finales del siglo XIX y principios del XX, la producción minera hondureña y mundial entró en receso y paralelamente comenzó a hacerse patente la creciente importancia de la producción y comercialización del banano en la costa norte del país. 
Artigo original

Hegemonia - Revista Eletrônica do Programa de Mestrado em Direitos Humanos, Cidadania e Violência/Ciência Política do Centro Universitário Unieuro

ISSN: 1809-1261

UNIEURO, Brasília, número 24, Julho a Dezembro de 2018, pp. 110-259.

En esta primera etapa, el control de la producción bananera estaba aún en manos de pequeños y medianos productores hondureños y extranjeros. No obstante, a principios del siglo XX, una serie de factores tanto internos como externos determinaron que la producción y comercialización del banano fuera absorbida totalmente por el capital norteamericano. El aumento del volumen de las embarcaciones, el desplazamiento más rápido de las mismas, la aparición del transporte refrigerado, la mayor demanda de bananos del mercado consumidor norteamericanos provocaron que a principios del siglo $\mathrm{XX}$, los comercializadores norteamericanos de bananos se convirtieron en plantadores directos en Honduras con lo cual se dio inicio al desarrollo del enclave bananero en Honduras $^{36}$.

En resumen, durante la primera etapa de la producción bananera en Honduras, las compañías bananeras solamente controlaban la comercialización de la fruta, mientras que eran los hondureños los que controlaban su cultivo y producción, sin embargo, desde principios del siglo XX las compañías norteamericanas pasaron a controlar la producción y comercialización del banano merced a la inversión de sus capitales en el establecimiento de compañías bananeras, lo cual también se vio favorecido por un amplio programa concesionario de parte del Estado de Honduras a dichos inversionistas americanos.

La primera compañía bananera norteamericana que se estableció en el país fue la "Vaccaro Brothers and Company" en 1899, durante el mandato del presidente Terencio Sierra, la cual obtuvo una ventajosa concesión para dedicarse al cultivo del banano en La Ceiba. Posteriormente, en 1911, Samuel Zemurray, que fue el empresario bananero que más incidió en la vida política y económica del país durante ese tiempo, organizó la "Cuyamel Fruit Company". Finalmente, en 1912, penetró en Honduras la "United Fruit Company" (UFCO), a través de sus subsidiarias, la "Tela Railroad Company" y la "Truxillo Railroad Company", con lo cual se consolidó el establecimiento del enclave bananero en el país.

\footnotetext{
${ }^{36}$ Posas, Mario, Luchas del movimiento obrero hondureño, San José de Costa Rica, Editorial Universitaria Centroamericana (EDUCA), 1981, p. 29.
} 
Artigo original

Hegemonia - Revista Eletrônica do Programa de Mestrado em Direitos Humanos, Cidadania e Violência/Ciência Política do Centro Universitário Unieuro

ISSN: 1809-1261

UNIEURO, Brasília, número 24, Julho a Dezembro de 2018, pp. 110-259.

Si bien la producción y comercialización de banano en gran escala se inició desde principios del siglo XX, es hasta la segunda década de ese siglo cuando dicho proceso alcanzó dimensiones importantes. De tal forma que para el año de 1924 Honduras se convirtió en el mayor exportador de banano del mundo, posición que mantuvo hasta el año de 1948. Según Kepner y Soothil, para el año de 1929 Honduras aportaba el 45,9\% del total de la producción mundial de banano.

Todo este éxito alcanzado por las compañías bananeras en Honduras respondió en gran parte a 2 factores: El régimen concesionario facilitado por el Estado de Honduras a los inversionistas americanos y el caudal de inversión de dichas compañías.

Las concesiones que otorgó el Estado a las compañías para que éstas se establecieran en Honduras fueron extremadamente generosas. En resumen, el régimen concesionario por lo general era el siguiente: uso gratuito de maderas y todo material existente en tierras nacionales para construcción de oficinas, bodegas y talleres para servicios de la ferrocarrilera de las compañías; exención de todo derecho fiscal o municipal establecido o que en lo sucesivo se establezca, importación libre para toda maquinaria, carros, herramientas, rieles y todo lo necesario para la producción bananera, pero quizá el más importante, el usufructo de tierras nacionales a cambio de la construcción de ferrocarriles. En cuanto al caudal de inversión norteamericana en las compañías bananeras, el monto representó en 1928, el 31\% del total de inversiones de los Estados Unidos en Centroamérica y Panamá.

De toda suerte, esta riqueza generada por las compañías bananeras era una "riqueza desnacionalizada", y a pesar que reportaba ciertos beneficios al país, la enorme cuantía de los recursos obtenidos de la producción y comercialización del banano eran reexportados a los Estados Unidos. Por esta razón es que Honduras recibió el apelativo de "Banana Republic" por antonomasia, imaginario que fue reproducido ampliamente en las tarjetas postales, tal como se verá en la sección que estamos reseñando.

De esa forma, las empresas transnacionales (mineras y bananeras) lograron controlar lo sustancial de la economía de Honduras, ya que aparte del control ejercido por ellas sobre los principales productos exportables del país, también controlaron el incipiente sector industrial y 
Artigo original

Hegemonia - Revista Eletrônica do Programa de Mestrado em Direitos Humanos, Cidadania e Violência/Ciência Política do Centro Universitário Unieuro

ISSN: 1809-1261

UNIEURO, Brasília, número 24, Julho a Dezembro de 2018, pp. 110-259.

comercial del país en ese tiempo. Así, las compañías transnacionales tuvieron bajo su control las principales fábricas del país, los ingenios azucareros, la producción eléctrica, las flotas que trasladaban el banano y el más importante aún: el de convertirse en prestamista de los gobiernos de ese entonces o ser los financistas de las guerras civiles en el país con el propósito de colocar presidentes que recompensaran y gratificaran sus necesidades económicas esenciales. Por todo lo anterior, las compañías transnacionales en virtud de su capacidad empresarial y de los capitales de que dispusieron, lograron copar el espacio económico del país a través de economías de enclave, es decir, dominando casi por completo el panorama económico, político y social del país.

\section{ILUSTRACIÓN 12}

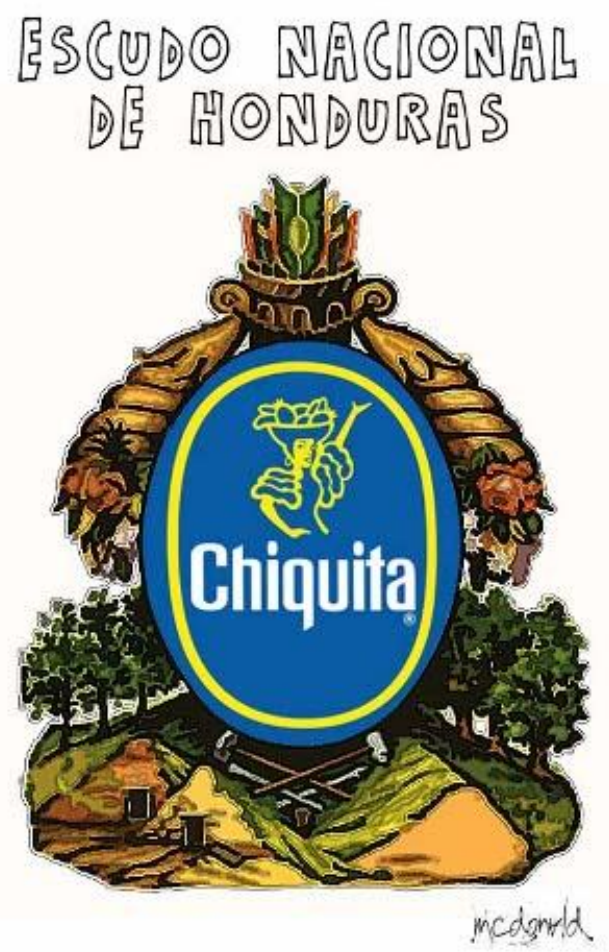

Dibujo del artista nacional Allan Mc Donald, que ilustra sin palabras el peso del enclave bananero en la historia hondureña, ironizando en este caso el "Escudo Nacional" y su lema de "República soberana e independiente" como una entelequia. 
Artigo original

Hegemonia - Revista Eletrônica do Programa de Mestrado em Direitos Humanos, Cidadania e Violência/Ciência Política do Centro Universitário Unieuro

ISSN: 1809-1261

UNIEURO, Brasília, número 24, Julho a Dezembro de 2018, pp. 110-259.

6) Los imaginarios de la "Banana Republic" en las tarjetas postales hondureñas

Con respecto a la temática de las postales bananeras, el repertorio es posiblemente de los más relevantes en la historia de las tarjetas postales hondureñas, en vista que fueron de las series más ampliamente reproducidas y difundidas, expresando por lo tanto una imagen bastante estereotipada del país como "Banana Republic".

Las imágenes son variadas y manifiestan varios significados que queremos resaltar. En primer lugar, hay un conjunto de postales que muestran simplemente los racimos de bananos; en estas imágenes el banano ocupa el sitio principal. Muchas de esas postales fueron mandadas imprimir por las mismas compañías bananeras, como la "Standard Fruit Company" y la "United Fruit Company" a través de sus subsidiarias la "Tela Railroad Company" y la "Truxillo Railroad Company" desde los años veinte hasta la segunda mitad del siglo XX. El objetivo era difundir propaganda del producto por excelencia que producían y exportaban las compañías fruteras, por lo tanto, son postales en donde el elemento humano -el obrero trabajador hondureño o “campeño"- está totalmente ausente. En este sentido, tal como analizó para el caso costarricense el historiador Enrique Camacho Navarro ${ }^{37}$, con estas postales de racimos de bananos se promocionaba la idea de un futuro esperanzador sustentado en los frutos tropicales. De este modo, mediante la lectura de postales en las que la temática gira alrededor del cultivo del banano, se puede evidenciar la existencia de un discurso visual que formularía una propuesta de imaginario en la cual los mensajes auguraban un futuro optimista y promisorio para Honduras a través de los bananos.

Este tipo de postales de racimos de bananos fueron tan recurrentes, que aún se imprimían a finales del siglo XX (como por ejemplo una editada por la "Librería Evangélica" de San Pedro Sula en los años setenta), o bien a principios del siglo XXI por la empresa IMAPRO de la ciudad

${ }^{37}$ Cfr. Camacho Navarro, Enrique, "Memorias de Costa Rica. Imaginarios en tarjetas postales", En: Revista Trinzunt, México DF, Centro de Investigaciones sobre América Latina y El Caribe, (UNAM), № 55, enero-junio del 2012, pp. 205-255. 
Artigo original

Hegemonia - Revista Eletrônica do Programa de Mestrado em Direitos Humanos, Cidadania e Violência/Ciência Política do Centro Universitário Unieuro

ISSN: 1809-1261

UNIEURO, Brasília, número 24, Julho a Dezembro de 2018, pp. 110-259.

de El Progreso, el corazón de la producción bananera, denotando el peso del banano como “imaginario de la nación” aún en la actualidad.

Este tópico de las "postales de racimos de bananos" era asimismo fundamental para las empresas fruteras como la UFCO y la "Standard" porque desde la primera mitad del siglo XX la producción de la mercancía se enfrentó al desafío de producir un mercado de consumo que fuera capaz de absorber niveles de producción de tipo industrial. Para hacer sostenibles altos niveles de producción, la empresa requirió de un público ávido del producto y del consumo.

Para producir el deseo de consumir bananas, la UFCO utilizó todas las herramientas propias de la "sociedad de masas" del siglo XX: los Medios de Comunicación de Masas inauguran inimaginables alternativas de llegar a grupos de población utilizando los progresos técnicos a través de un discurso publicitario adecuado a las necesidades de los consumidores y de la empresa. La UFCO generó así un aparato publicitario de primer nivel: afiches, dibujos animados, documentales, libros, música, personajes (el más eficaz fue sin duda el personaje de "Carmen Miranda" identificada también como "Chiquita Banana") y por supuesto tarjetas postales ${ }^{38}$.

Carmen Miranda, cantante brasileña identificada con "Chiquita Banana", será uno de estos claros estereotipos que trasciende largamente la estrategia mercantil de la UFCO, que más bien habla de una representación cultural creada, producida y difundida en los Estados Unidos. Esta imagen de los hondureños (y por extensión de los latinoamericanos) como personas eminentemente festivas, exóticas, lúdicas, sensualizadas y ociosas, es parte del "sistema de argumentos que autorizaba la presencia y producción cultural de los estadounidenses en el extranjero, así como de su Imperialismo"39, y que sobretodo consolidaba la identidad "del otro" en la diferencia y la lejanía, exotismo que establece una relación de poder entre ambas partes, al no tratarse de relaciones horizontales sino de una parte civilizada y productora frente a otra lúdica y festiva, en una caricaturización cultural y esencialización de la identidad latinoamericana. Como señalara

\footnotetext{
38 Silva Salinas, Camila, La United Fruit Company, construcción cultural del consumo y defensa armada del capital, En: http://debananasybatallas.blogspot.com/2007_12_01_archive.html, consultado 8/3/2017.

39 Véase: Salvatore, Ricardo, Imágenes de un imperio: Estados Unidos y las formas de representación de América Latina, Buenos Aires, Editorial Sudamericana, 2006, p. 27.
} 
Artigo original

Hegemonia - Revista Eletrônica do Programa de Mestrado em Direitos Humanos, Cidadania e Violência/Ciência Política do Centro Universitário Unieuro

ISSN: 1809-1261

UNIEURO, Brasília, número 24, Julho a Dezembro de 2018, pp. 110-259.

Edward Said para la relación de Oriente y Occidente, la visión del otro era una construcción preestablecida y en ese sentido, los occidentales, en este caso, los norteamericanos, ven lo que quieren ver, para describirlo, enseñarlo, colonizarlo y decidir sobre él ${ }^{40}$.

Por otro lado, el público al que se deseaba llegar era el ciudadano promedio de clase media norteamericano, cuyo nivel de ingresos le permitiera sostener un nivel de consumo constante. Para ello se utilizaba un "discurso de carácter pedagógico" que buscaba educar a la población en las bondades del consumo de bananas, destacando sus cualidades nutricionales, la rapidez y simpleza de su consumo, lo cual convertía al banano en un producto adecuado para toda la familia, en especial para los niños. Por otro lado, era necesario derribar prejuicios y mitos respecto al consumo de la banana, como por ejemplo, el que condenaba que las mujeres comieran plátanos en espacios públicos por una clara alusión sexual. Muy al contrario, la propaganda creada y difundida por la UFCO vio en las dueñas de casa de clase media uno de los personajes centrales hacia quienes dirigir su aparato publicitario, ya que a partir de la "conquista de las madres", se procuraba imponer el consumo al resto de la familia. En suma, la UFCO se preguntó a través de esa publicidad en afiches y tarjetas postales ¿Quién se comería los plátanos producidos en Honduras y América Central?. La respuesta que esperaban era que TODA Norteamérica -y desde luego el resto del mundo- ${ }^{41}$.

\footnotetext{
${ }^{40}$ Cfr. Said, Edward, Orientalismo, Madrid, Debate, 2002.

${ }^{41}$ Silva Salinas, Camila, La United Fruit Company... Op. Cit.
} 
Artigo original

Hegemonia - Revista Eletrônica do Programa de Mestrado em Direitos Humanos, Cidadania e Violência/Ciência Política do Centro Universitário Unieuro

ISSN: 1809-1261

UNIEURO, Brasília, número 24, Julho a Dezembro de 2018, pp. 110-259.

\section{ILUSTRACIÓN 13}

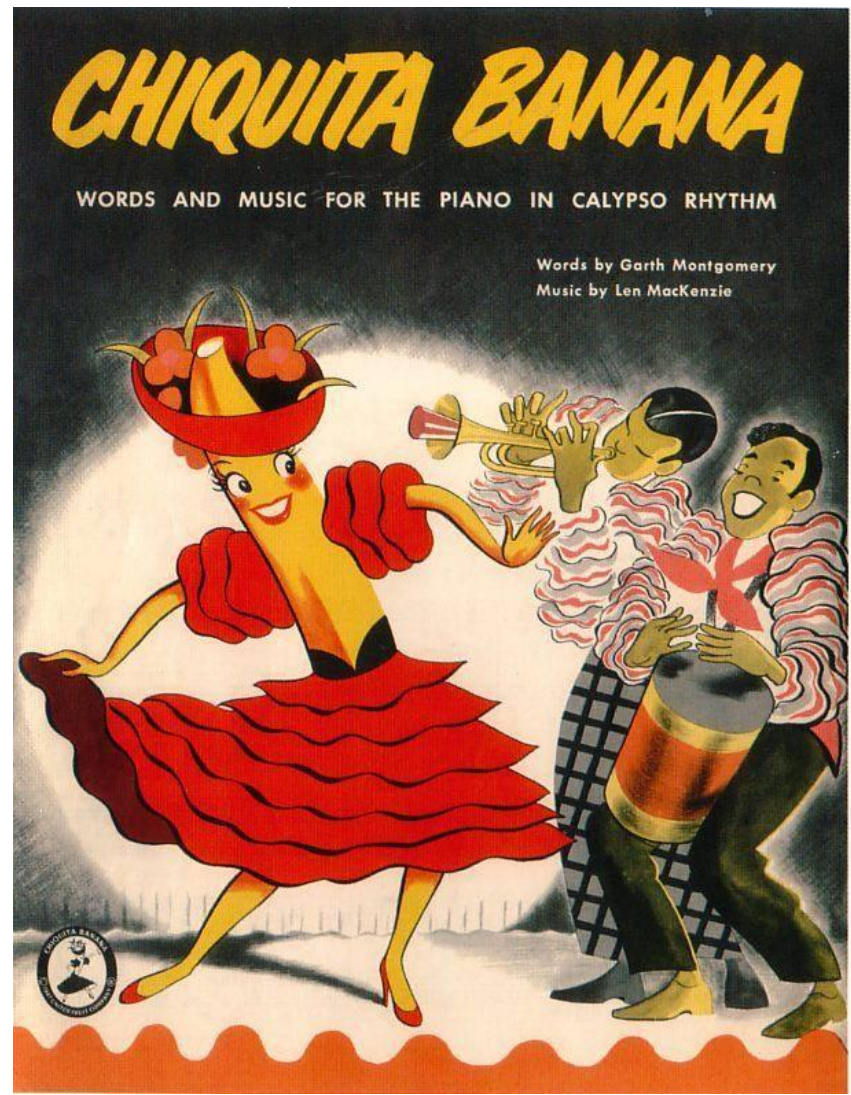

Carmen Miranda o "Chiquita Banana", uno de los personajes publicitarios clave de la UFCO para imponer el consumo del banano en Norteamérica y el mundo.

En el caso de la "sensualización” y "exotización" del cuerpo de las mujeres hondureñas habitantes de las regiones bananeras con la finalidad de explotar el mito del "Jardín del Edén" similar a la función erotizante de Carmen Miranda-, ha sido estudiado magistralmente por el historiador Kevin Colemán ${ }^{42}$, en una investigación sobre la obra del artista fotógrafo don Rafael Plateros, quien desarrolló su labor en la Ciudad de El Progreso. En dicho artículo, Coleman comparte una estampa de un fotógrafo anónimo que trabajaba para la reconocida y popular revista Life Magazine, quien tomó un fotografía de una muchacha indígena hondureña (la Eva “tentada" la llamó el artista), cubriéndose con una hoja de banano gigantesca (ver figura 11.

\footnotetext{
${ }^{42}$ Coleman, Kevin, "Una óptica igualitaria: Autorretratos, construcción del ser y encuentro Homo-social en una plantación bananera de Honduras", En: Revista Diálogos: Revista Electrónica de Historia, San José de Costa Rica, Universidad de Costa Rica (UCR), Escuela de Historia, Vol. 16, № 2, julio-diciembre de 2015, pp. 123-164.
} 
Artigo original

Hegemonia - Revista Eletrônica do Programa de Mestrado em Direitos Humanos, Cidadania e Violência/Ciência Política do Centro Universitário Unieuro

ISSN: 1809-1261

UNIEURO, Brasília, número 24, Julho a Dezembro de 2018, pp. 110-259.

\section{ILUSTRACIÓN 14}

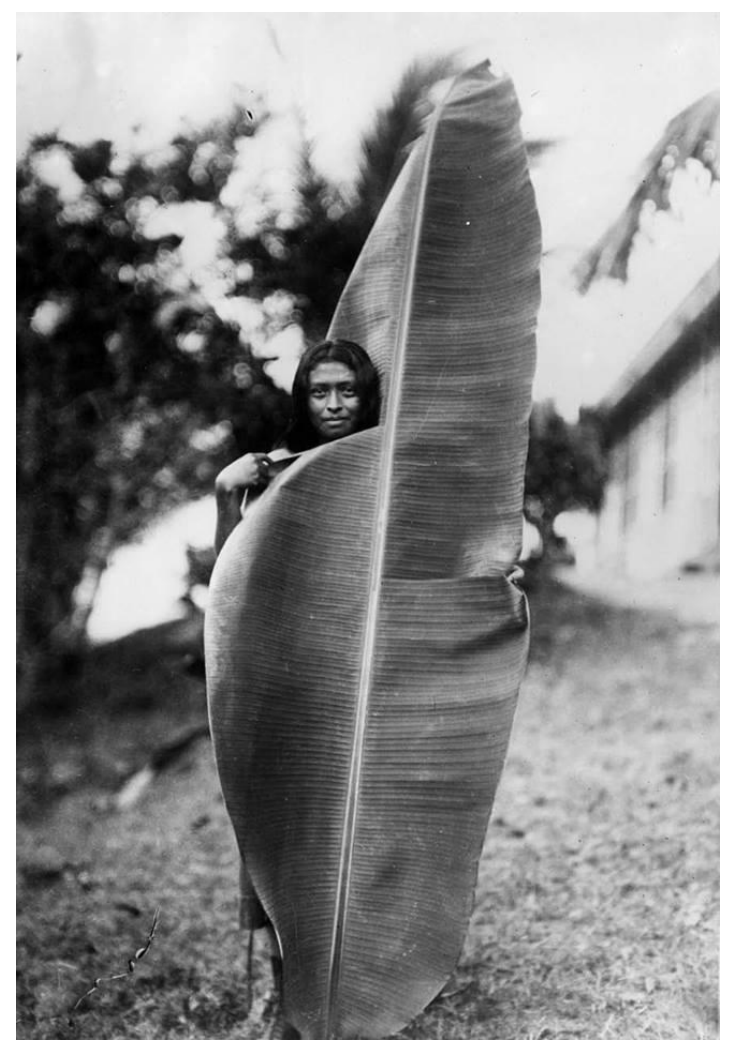

"La Eva tentada", subtitulada a pie de foto como "Jardín del Edén”, fotografía de autor desconocido publicada en Time Life, descargada de los archivos de "Getty Images".

La revista Life fue pionera en el periodismo fotográfico y para 1938 tenía una circulación masiva de aproximadamente 80,000 suscriptores, con unas ventas adicionales de ejemplares al menudeo que alcanzaban el millón de copias ${ }^{43}$. Según Coleman, los tropos que guían esta "representación" del "Jardín de Edén hondureño" son la vergüenza de esconder el cuerpo ante los ojos del Otro. La hoja vertical se convierte en esa foto en un significante divisorio de la vergüenza y del órgano sexual masculino que visualmente intercepta el cuerpo de la mujer. Empero, la "vergüenza" es parcial y artificial en la medida en que la imagen ha sido claramente producida por el fotógrafo con la aparente complicidad y consentimiento del sujeto. La escala de la hoja de banano y la mujer que se utiliza para demostrar el aspecto "gigante" de esa hoja acentúan la proeza de la horticultura estadounidense, ofreciendo otro ejemplo del poder de la United Fruit Company en

${ }^{43}$ Ibíd., p. 151. 
Artigo original

Hegemonia - Revista Eletrônica do Programa de Mestrado em Direitos Humanos, Cidadania e Violência/Ciência Política do Centro Universitário Unieuro

ISSN: 1809-1261

UNIEURO, Brasília, número 24, Julho a Dezembro de 2018, pp. 110-259.

Centroamérica. Es posible imaginar la reacción de algunos lectores estadounidenses: “¡Una sola hoja de banano empequeñece a esta dama de piel oscura!”.

Esta fotografía tomada por Life no era claramente un autorretrato y se tomó para los ojos de los espectadores estadounidenses. La mujer era un objeto para la vista de esos estadounidenses y calzaba dentro de los estereotipos que los estadounidenses tenían sobre los centroamericanos a inicios del siglo XX. Esta mujer es, para parafrasear a Homi Bhabha, un objeto apropiado "de una cadena de mando colonialista", una versión autorizada de la otredad ${ }^{44}$. Esta visión estadounidense del "Paraíso" indica que la imagen busca retratar la "belleza" y la "inocencia" no de una sola persona, sino de un lugar y un pueblo (antes del pecado original). Y si la joven es de hecho un reflejo del país entero, entonces Honduras es "exótica, modesta, inocente y posiblemente curiosa" respecto de quien la mira. Aún así, también es precavida y no quiere revelarse completamente. Por tanto, estamos en presencia de una bien arreglada alegoría de las relaciones entre Estados Unidos y Honduras, una recreación de la mirada dominante estadounidense y de "la Honduras" que los norteamericanos deseaban ver: la "Banana Republic"45.

La "Banana Republic" se transpone del país al texto y al ícono. Las relaciones capitalistas y neocoloniales no se codifican solamente de forma visual en este espécimen botánico y antropológico; fueron repetidas e intensificadas cuando el fotógrafo se iba con su negativo. Es muy probable que la modelo no recibiera ni dinero, ni una copia de la imagen. En su lugar, la foto fue vendida a la revista, donde se unió a una sucesión de imágenes y textos que los lectores compraron y que ahora se pueden rentar en la compañía “Getty Images” por $\$ 331$. Esa foto se volvió parte de una más amplia gama de imágenes paisajísticas que alimentaron el apetito estadounidense por las aventuras imperialistas ${ }^{46}$.

\footnotetext{
${ }^{44}$ Bhabha, Homi, The Location of Culture, Estados Unidos, Routledge, 2003.

45 Coleman, Kevin, “Una óptica igualitaria...”, Op. Cit., p. 150.

46 Ibíd., p. 150.
} 
Artigo original

Hegemonia - Revista Eletrônica do Programa de Mestrado em Direitos Humanos, Cidadania e Violência/Ciência Política do Centro Universitário Unieuro

ISSN: 1809-1261

UNIEURO, Brasília, número 24, Julho a Dezembro de 2018, pp. 110-259.

Finalmente, Coleman señala que a pesar de los mensajes explícitamente transmitidos por decisión del editor del pie de página de la foto y por los arreglos hechos por el fotógrafo de los participantes representados, es posible realizar una lectura no intencionada y antiimperialista de esta imagen. Mientras que la "naturaleza" y la "inocencia perdida" son significados intencionados, comunicados textual y visualmente, al mirarlos más detalladamente nos damos cuenta de que esos significados se contradicen por efecto de la casa o el edificio, que intencionalmente aparecen difusos por el uso de una toma más abierta de la fotografía. Incluso, aunque esas construcciones aparecen difusas, los bordes cuadrados y los aleros del techo sugieren la presencia de la "modernidad" y niegan la interpretación intencional de un "Jardín del Edén" o de una comunidad indígena "natural". Otro detalle que pone en problemas la mirada imperialista es la presencia de un pedacito de la enagua de la mujer asomándose en la parte de abajo de la hoja: jella no es una "india" desnuda, sino que tiene ropa!. Estos detalles subrayan la naturaleza artificial de este hecho fotográfico, y revelan involuntariamente que la imagen fue hecha para los ojos estadounidenses, que querían ver una particular Honduras "tribal". Así, lo que vemos y lo que un astuto espectador en 1925 podía mirar, es el proceso de creación de la ideología cultural que suscribió las actividades de las compañías fruteras estadounidenses en Centroamérica.

Por otro lado, un segundo eje temático de las tarjetas postales del enclave bananero serán las imágenes que exponen el proceso del ciclo de producción, desde la cosecha y corte de bananos por parte de los obreros o “campeños" (a quienes se denominaba como "cortadores"), quienes realizaban una dura faena cortando la fruta con machete, para luego acarrear el banano en carretas de mulas o de bueyes, hasta bodegas de los campos bananeros o "fincas" donde eran empacadas, y luego depositadas en los ferrocarriles para después conducirlas hasta los muelles por un ejército de "cargadores" que subían los bananos a los barcos de la "Gran Flota Blanca" en muelles como Puerto Cortés, Tela, La Ceiba y Trujillo en el litoral Caribe hondureño. Esta serie denotaba un gran proceso de "racionalización" de la producción en el sentido "weberiano" del término.

Finalmente, hay un tercer tópico temático en el cual se ve la impronta de la cultura norteamericana estampada y trasplantada a los espacios y territorios de la Costa norte hondureña, 
Artigo original

Hegemonia - Revista Eletrônica do Programa de Mestrado em Direitos Humanos, Cidadania e Violência/Ciência Política do Centro Universitário Unieuro

ISSN: 1809-1261

UNIEURO, Brasília, número 24, Julho a Dezembro de 2018, pp. 110-259.

manifestada en la arquitectura de los poblados bananeros; de este modo, en San Pedro Sula, La Lima, Puerto Cortés, El Progreso, Tela, La Ceiba, Olanchito y Trujillo se ven espacios urbanos construidos (o mejor reconstruidos) al estilo de la arquitectura victoriana del sur de los Estados Unidos (especialmente de la zona de Lousiana y del Medio Oeste norteamericano), con casas y edificaciones de madera y techos de zinc, fabricadas en Estados Unidos y reenviadas a Honduras para ser ensambladas in situ ${ }^{47}$.

Los efectos sociales de la presencia de estas empresas fruteras en Honduras fueron profundos, modificando la vida cotidiana en las plantaciones y los patrones culturales de las sociedades locales. Las plantaciones se extendieron profusamente entre 1900 y 1930, época en que la producción de bananas alcanzó mayor relevancia.

La primera reacción a la presencia norteamericana provino de parte de los mismos sujetos que vivían en contacto directo con la bananera en los enclaves de las Compañías. La introducción del modo de producción capitalista modificó las prácticas económicas de los pequeños campesinos y comunidades indígenas de la región, estableciendo un nuevo concepto de trabajo remunerado con efectos a nivel social.

Los trabajadores de las compañías, asentados en enclaves habitacionales especialmente construidos para ellos, llamados en Honduras "barracones" -separados de las "zonas residenciales americanas"-, carecían por lo general de los mismos servicios con que se dotaba a los funcionarios "gringos"; esto llevó a la mano de obra de los "campeños" hondureños (indígenas y mestizos en su mayoría), así como a los inmigrantes negros de habla ingleses arribados desde Jamaica a reivindicar sus derechos a través de huelgas, plantones y otras formas de protesta casi siempre reprimidas por las fuerzas de choque de las compañías y por las fuerzas represivas del Estado hondureño.

${ }^{47}$ Este tema ha sido ampliamente estudiado por Daniela Navarrete. Cfr. Diversidad patrimonial de las ciudades en Honduras, Tegucigalpa, Instituto Hondureño de Antropología e Historia (IHAH), Colección Centros Históricos, 2008. 
Artigo original

Hegemonia - Revista Eletrônica do Programa de Mestrado em Direitos Humanos, Cidadania e Violência/Ciência Política do Centro Universitário Unieuro

ISSN: 1809-1261

UNIEURO, Brasília, número 24, Julho a Dezembro de 2018, pp. 110-259.

Es entre estos trabajadores que la UFCO comenzó a ser conocida como la "Prisión verde" (en alusión a la novela de Ramón Amaya Amador $^{48}$ ), y que para los obreros simbolizó en ocasiones la oportunidad de sobrevivir con un trabajo, pero en otros momentos implicó un verdadero infierno o prisión: era la compañía la que daba trabajo, vivienda, salud, educación; y también imponía a mano dura el orden, control, vigilancia y castigo. En este sentido, las fruteras llegaron a operar como un "Estado paralelo", un "Estado dentro de otro Estado", en cuanto cumplía funciones que los gobiernos locales eran incapaces de cumplir por múltiples motivos. Mientras tanto, para los funcionarios, administradores y trabajadores gringos especializados, la compañía recreó la "sociedad norteamericana original", creando verdaderas ciudades separadas del resto (conocidas como la "zona americana"), que permitieran a sus funcionarios la mantención de un tren de vida similar al que vivían en Estados Unidos.

Asimismo, en este mismo eje temático, exponemos un conjunto de tarjetas postales que expresan la idea de una especie de "misión civilizadora" de las compañías bananeras en Honduras, a través de imágenes que representan los "adelantos" y la "Modernidad" que son introducidos a Honduras por medio de una serie de prácticas culturales diversas y representativas de la Modernidad: arquitectura de estilo "art nouveau", sobre todo el estilo "art deco", así como una gama de nuevas diversiones como "carreras de caballos", los deportes norteamericanos como el "béisbol”, el "golf”; servicios modernos como los ferrocarriles (quizás el símbolo máximo de la Modernidad), automóviles, muelles, barcos (de nuevo la Gran Flota Blanca), avenidas y bulevares asfaltados, puentes de hierro (símbolo de la Revolución Industrial), "hospitales", "escuelas bilingües", "tiendas de raya" o "comisariatos", productos enlatados, "hoteles", "bares", "cervecerías", "restaurantes".

En este sentido, la producción de bananas se planteó por parte de las transnacionales en “términos civilizadores", lo cual se visualizó a través de las tarjetas postales, destacando el progreso que la UFCO estaba introduciendo en Honduras y los países centroamericanos, al impulsar "polos de desarrollo" en la región. Como parte de los esfuerzos por consolidar un mercado interno, se desarrolló por medio de la publicidad y de las tarjetas postales una serie de

48 Véase: Amaya Amador, Ramón, Prisión verde, El Progreso, Editorial Ramón Amaya Amador, 26ª edición, 2010. 
Artigo original

Hegemonia - Revista Eletrônica do Programa de Mestrado em Direitos Humanos, Cidadania e Violência/Ciência Política do Centro Universitário Unieuro

ISSN: 1809-1261

UNIEURO, Brasília, número 24, Julho a Dezembro de 2018, pp. 110-259.

propaganda interna que difundía el "sentido civilizador" de la presencia de Estados Unidos en el panorama regional del istmo. De este modo, se difundieron millares de postales que transmitían este "discurso civilizador y modernizador", que intentaba potenciar el mercado interno y generar una "imagen positiva" en la opinión pública, en cuanto la empresa "estaba supuestamente cumpliendo y aportando en la misión nacional" de lograr el desarrollo y la Modernidad ante el resto del mundo. Por su parte, cuando las postales eran remitidas al exterior -especialmente a los Estados Unidos y a Europa-, se pretendía plasmar con ellas un referente para que los anglosajones percibieran la magnitud del progreso que traía la UFCO en estos territorios antes dominados por la "barbarie".

Efectivamente, la parafernalia y estética moderna que se visualizaba en las postales de temática bananera (con los paisajes urbanos modernizados al estilo del sur de los Estados Unidos), en que se ilustraban estampas de calles y bulevares asfaltados, edificios de arquitectura moderna, ferrocarriles, automóviles, hoteles, restaurantes, diversiones modernas como el béisbol o el golf, etcétera, pretendían referir que las compañías bananeras habían llegado no solamente a subyugar y dominar los espacios selváticos de la costa norte hondureña, sino también, que habían llegado a "civilizar" el cuerpo de los hondureños, insinuando que habitaban por tanto en la "barbarie".

De esta forma, en la medida que las compañías fruteras extendieron sus intereses económicos en Honduras, simultáneamente construyeron una verdadera "geografía del poder", legitimada mediante la cultura, en cuanto "la comunidad mercantil ya sabía que ese modo de proceder, esa forma de construcción del imperio informal (la apropiación violenta), era un hecho consumado, por tanto, era también necesario una incorporación intelectual de los nuevos territorios al universo cultural y social norteamericano. Es decir, era necesario legitimar y hegemonizar su discurso, su propia interpretación de las relaciones de poder con los países, cuya conjugación más eficiente fue la conformación de una "hegemonía cultural e intelectual" sobre la representación del "otro latinoamericano" como un sujeto por civilizar. En síntesis, la idea era 
Artigo original

Hegemonia - Revista Eletrônica do Programa de Mestrado em Direitos Humanos, Cidadania e Violência/Ciência Política do Centro Universitário Unieuro

ISSN: 1809-1261

UNIEURO, Brasília, número 24, Julho a Dezembro de 2018, pp. 110-259.

implantar la Modernidad y la impronta cultural norteamericana, en otras palabras, "americanizar" o "agringar" al país".

Finalmente, a pesar de la gravitación negativa que ha tenido el apelativo de "Banana Republic" sobre Honduras, tenemos que matizar que la realidad social e histórica del país es mucho más compleja que esa imagen anodina de "republiqueta bananera" que ha querido atribuírsele al país; Honduras es más compleja y diversa; a lo largo de su historia, intelectuales, artistas y personajes populares se rebelaron contra la penetración del imperialismo y de las compañías bananeras, lucharon contra las injusticias generadas por la instalación de ese capitalismo extractivista importado con el enclave bananero; prueba de ello fueron las gestas patrióticas de Froylán Turcios en 1924 cuando enfrentó la invasión de los Marines yanquis en Tegucigalpa, la gran huelga bananera de 1954 o las luchas de los movimientos campesinos, sindicales, magisteriales y estudiantiles, y más recientemente el movimiento indígena liderado por la inmolada compatriota lenca Bertita Cáceres. A la memoria de todos esos patriotas que creyeron que Honduras es y debe ser más que una "Banana Republic" va dedicado también este ensayo. Que el mundo entero sepa entonces que ha habido y hay hondureños y hondureñas que resisten y defienden con dignidad la soberanía y el derecho del Estado de Honduras a ser una república libre, soberana e independiente...

A continuación, para complementar el análisis teórico con el visual, pasamos a compartir las postales elegidas para intentar explicar el mito de la "Banana Republic" en Honduras a través de las tarjetas postales.

${ }^{49}$ Salvatore, Ricardo, Imágenes de un imperio... Op. Cit., p. 94. 
Artigo original

Hegemonia - Revista Eletrônica do Programa de Mestrado em Direitos Humanos, Cidadania e Violência/Ciência Política do Centro Universitário Unieuro ISSN: $1809-1261$

UNIEURO, Brasília, número 24, Julho a Dezembro de 2018, pp. 110-259.

POSTAL 1

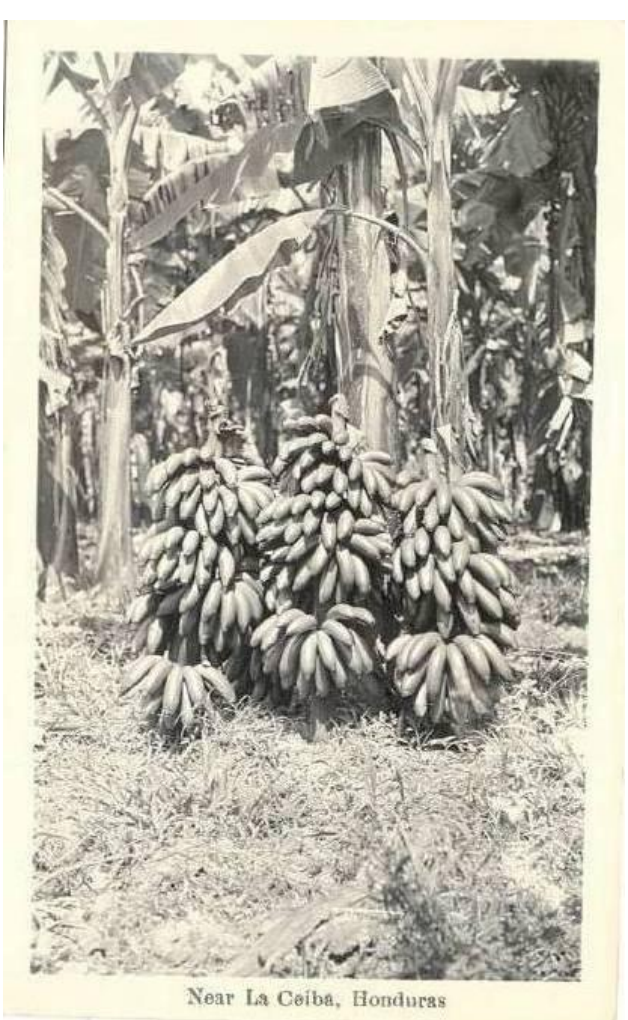

Tarjeta postal impresa por encargo de la "Standard Fruit Company", de finales de los años veinte. Este tipo de postales muestran simplemente los racimos de bananos, como si per sé el banano fuera un "personaje" dotado de ser; en estas imágenes el banano ocupa el sitio principal. El objetivo era difundir propaganda del producto por excelencia que producían y exportaban las compañías fruteras, por lo tanto, son postales en donde el elemento humano -el obrero trabajador hondureño o "campeño"- está totalmente ausente. 
Artigo original

Hegemonia - Revista Eletrônica do Programa de Mestrado em Direitos Humanos, Cidadania e Violência/Ciência Política do Centro Universitário Unieuro ISSN: $1809-1261$

UNIEURO, Brasília, número 24, Julho a Dezembro de 2018, pp. 110-259.

POSTAL 2

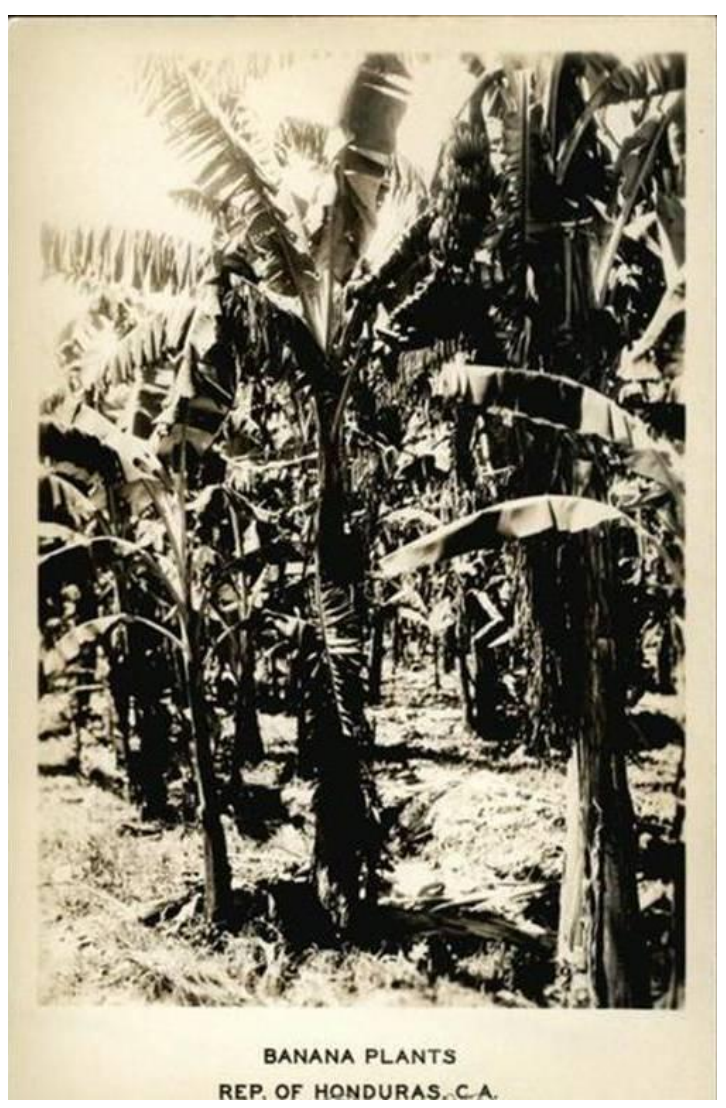

Otra tarjeta postal perteneciente a una serie que publicó en los años treinta la "United Fruit Company", a través de su subsidiaria en Honduras, la "Truxillo Railroad Company", en la que nuevamente se asigna protagonismo a racimos de bananos, resaltando con ello el imaginario del banano como lo más connotativo de las representaciones sociales del mundo de las compañías fruteras en Centroamérica. Ello contribuyó por lo tanto a forjar una imagen de Honduras como "Banana Republic". 


\section{Artigo original}

Hegemonia - Revista Eletrônica do Programa de Mestrado em Direitos Humanos, Cidadania e Violência/Ciência Política do Centro Universitário Unieuro ISSN: 1809-1261

UNIEURO, Brasília, número 24, Julho a Dezembro de 2018, pp. 110-259.

\section{POSTAL 3}

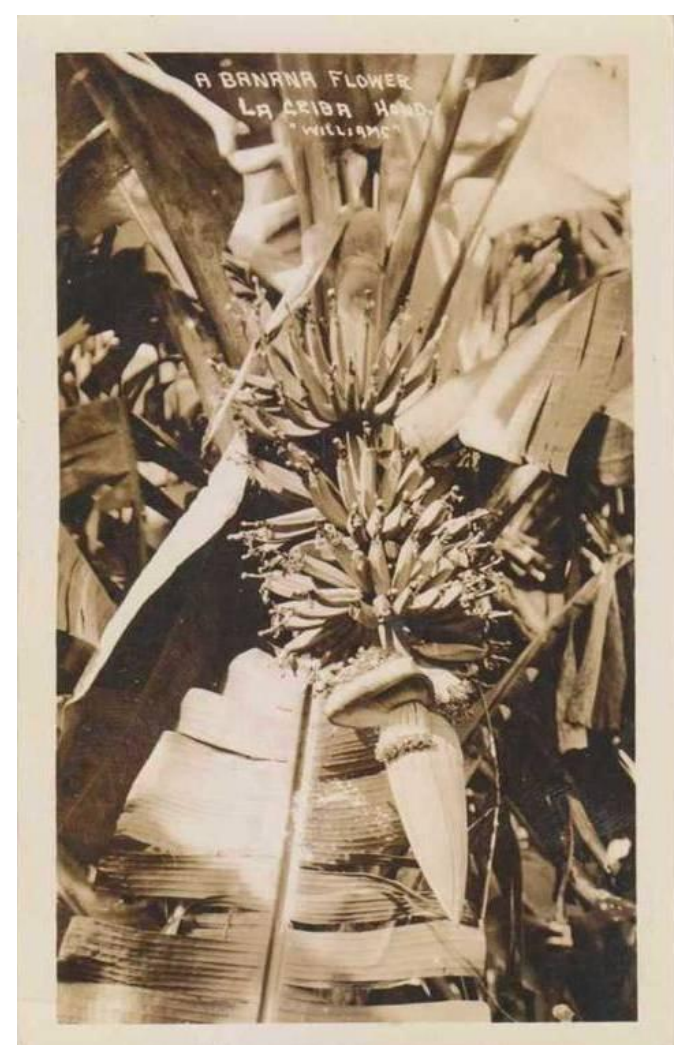

Otra magnífica fotografía de los años cuarenta, obra del emblemático artista fotógrafo de origen jamaiquino, Teodhore Williams, quien vivió en La Ceiba, Atlántida, y se convirtió quizás en el principal documentalista visual de la época en la costa norte. Como se observa, se reitera la estampa de los racimos de bananos como emblemas del paisaje y rostro del territorio donde se asentaron las compañias transnacionales fruteras. 
Artigo original

Hegemonia - Revista Eletrônica do Programa de Mestrado em Direitos Humanos, Cidadania e Violência/Ciência Política do Centro Universitário Unieuro ISSN: $1809-1261$

UNIEURO, Brasília, número 24, Julho a Dezembro de 2018, pp. 110-259.

POSTAL 4

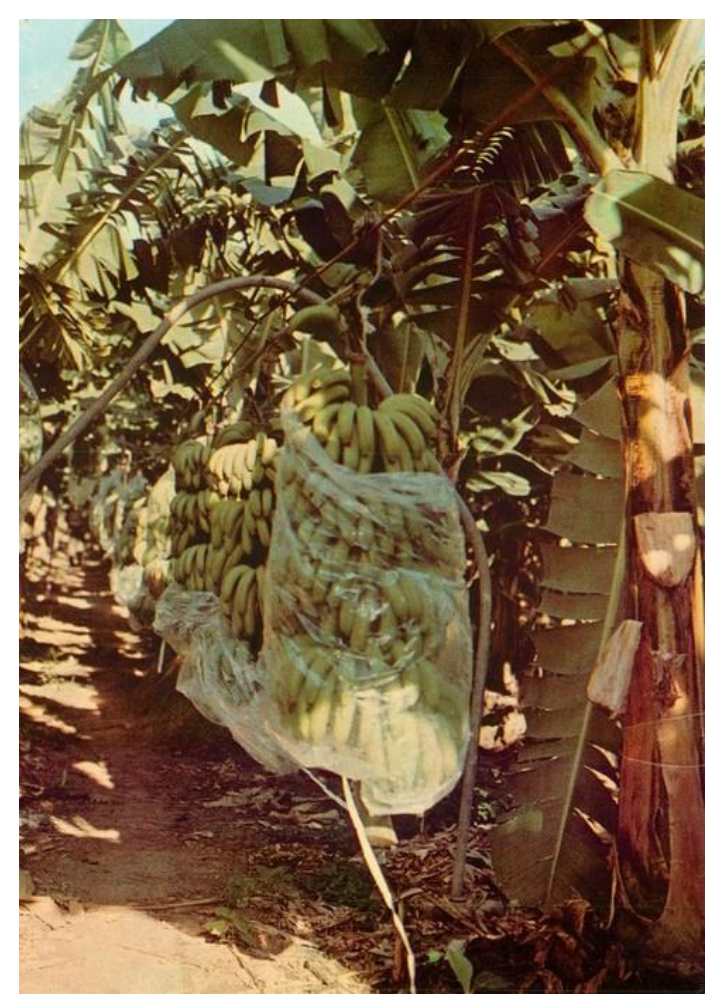

Racimo de banano de la "Finca Omonita", en el departamento de Cortés, en esta tarjeta postal publicada por la "Librería Evangélica" de San Pedro Sula en 1978. Es interesante advertir la fuerza del banano como "imaginario de la nación" y como metáfora de la "Banana Republic", aún ya bien avanzado el siglo XX, como en esta tarieta publicada en los años setenta. 
Artigo original

Hegemonia - Revista Eletrônica do Programa de Mestrado em Direitos Humanos, Cidadania e Violência/Ciência Política do Centro Universitário Unieuro ISSN: $1809-1261$

UNIEURO, Brasília, número 24, Julho a Dezembro de 2018, pp. 110-259.

POSTAL 5

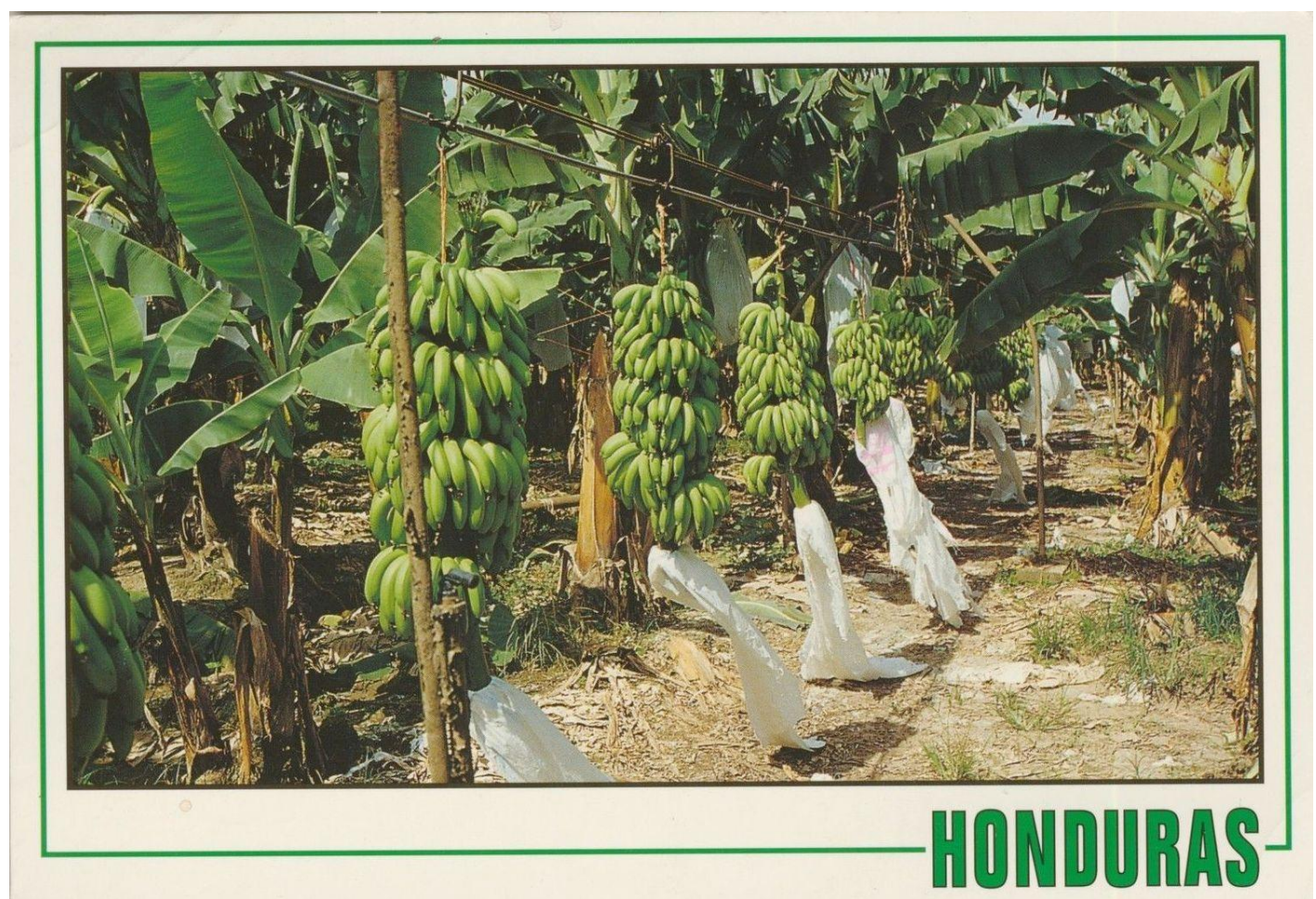

De manera interesante, esta tarjeta postal impresa por la "IMAPRO" de la ciudad de El Progreso, Yoro, publicó esta postal de racimos de bananos en los años noventa del siglo recién pasado. Como se ha visto en esta secuencia de imágenes, desde los años veinte hasta el presente, una de las imágenes emblemáticas de representación del paisaje bananero ha sido una foto o estampa de racimos o matas de bananos, configurando en gran medida la imagen de Honduras como una "Banana Republic". 
Artigo original

Hegemonia - Revista Eletrônica do Programa de Mestrado em Direitos Humanos, Cidadania e Violência/Ciência Política do Centro Universitário Unieuro ISSN: $1809-1261$

UNIEURO, Brasília, número 24, Julho a Dezembro de 2018, pp. 110-259.

POSTAL 6

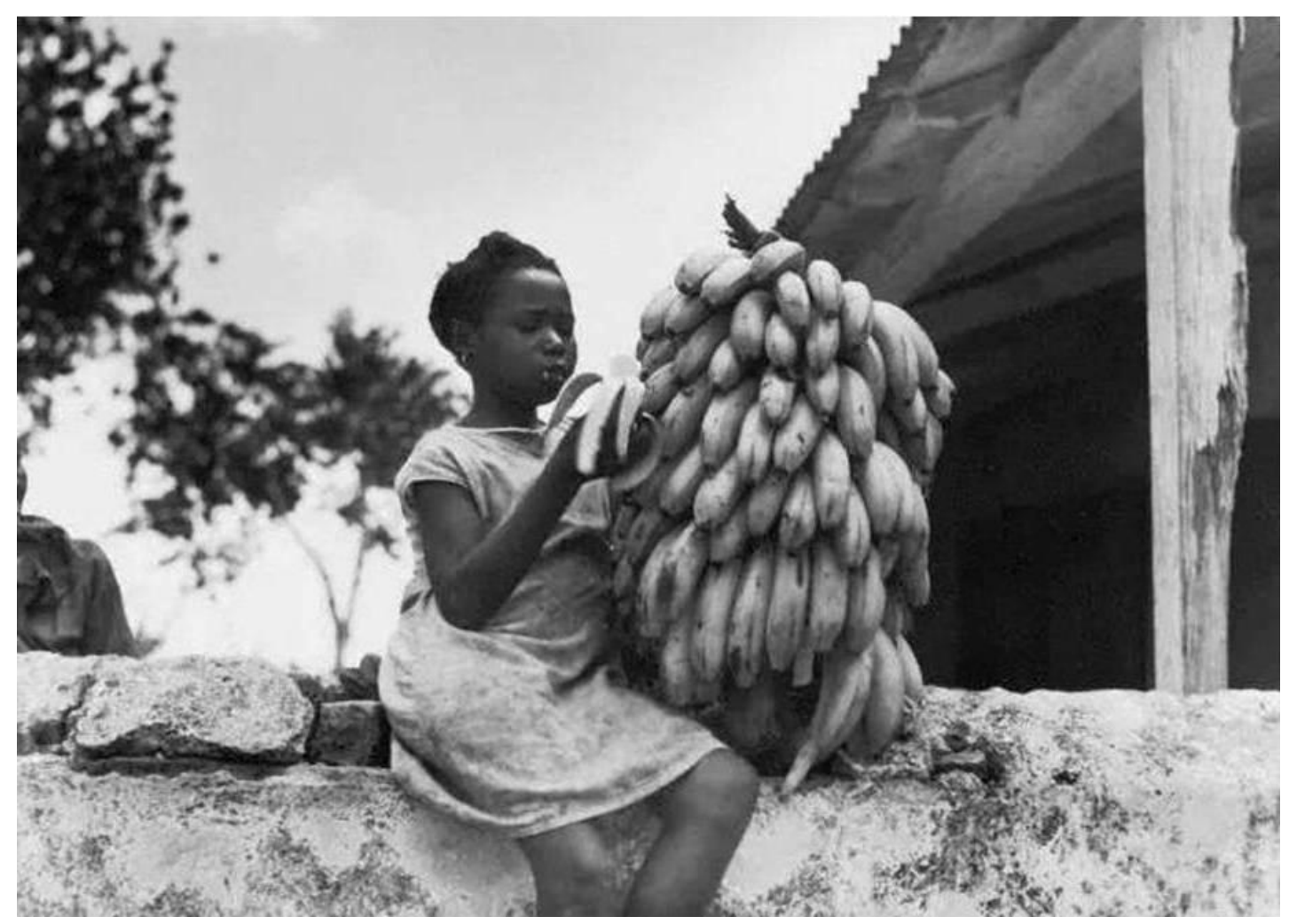

Sensacional postal de una niña Garífuna comiendo bananas en las cercanías de La Ceiba, en los años cuarenta. Los Garífunas fueron uno de los pueblos que aportaron una mano de obra fundamental para la industria bananera, siendo copartícipes con los mestizos y los Negros Ingleses del proletariado obrero de las Bananeras. De hecho, los plátanos y bananos son un consumo esencial en la dieta de los Garífunas hondureños. Esta postal, a diferencia de las anteriores, es de las primeras que muestra a la fruta del banano asociada con la cultura de la costa norte hondureña. 
Artigo original

Hegemonia - Revista Eletrônica do Programa de Mestrado em Direitos Humanos, Cidadania e Violência/Ciência Política do Centro Universitário Unieuro ISSN: $1809-1261$

UNIEURO, Brasília, número 24, Julho a Dezembro de 2018, pp. 110-259.

\section{POSTAL 7}

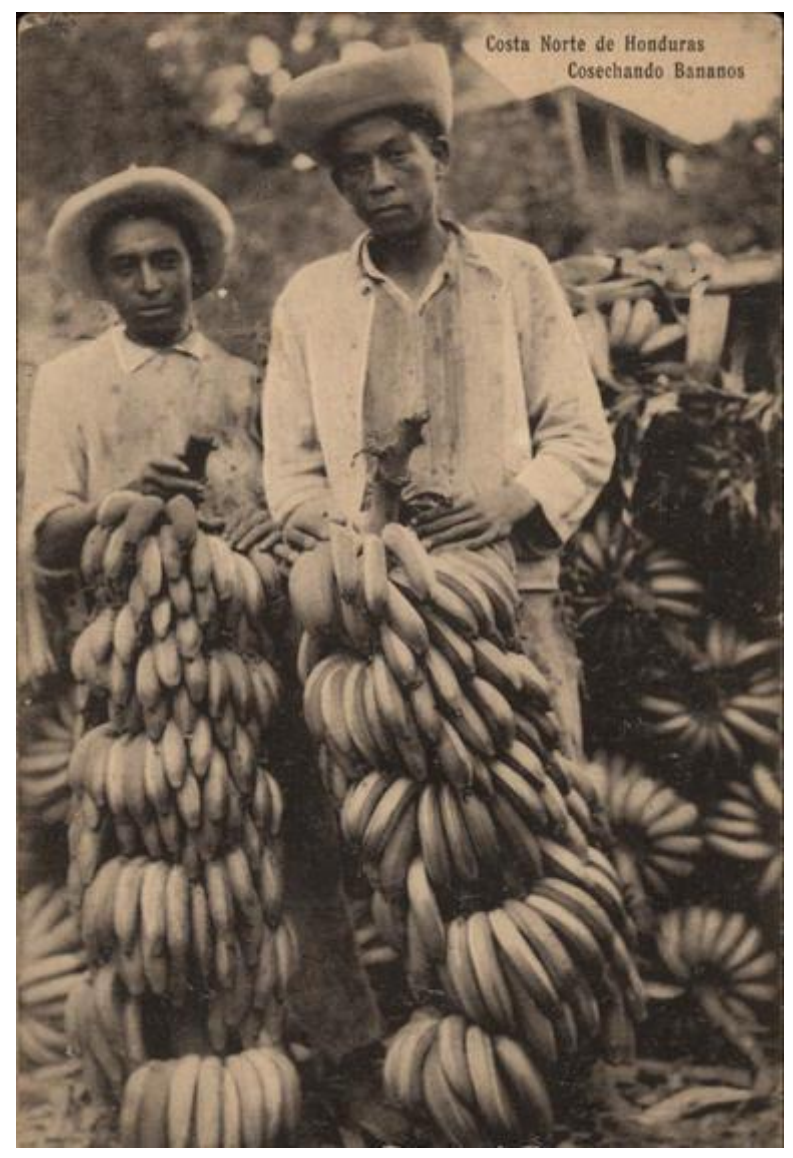

Interesante postal, obra del artista fotógrafo de origen italiano Carmelo Celano, de 1921, quien vivió y publicó postales en Puerto Cortés, en donde se intenta plasmar el binomio bananas/campeños en armonía, expresando de cierta manera el imaginario de que las compañías bananeras se instalaban en estas "Banana Republic" para aportar al trabajo y desarrollo de estos tropicales países. 
Artigo original

Hegemonia - Revista Eletrônica do Programa de Mestrado em Direitos Humanos, Cidadania e Violência/Ciência Política do Centro Universitário Unieuro ISSN: 1809-1261

UNIEURO, Brasília, número 24, Julho a Dezembro de 2018, pp. 110-259.

\section{POSTAL 8}

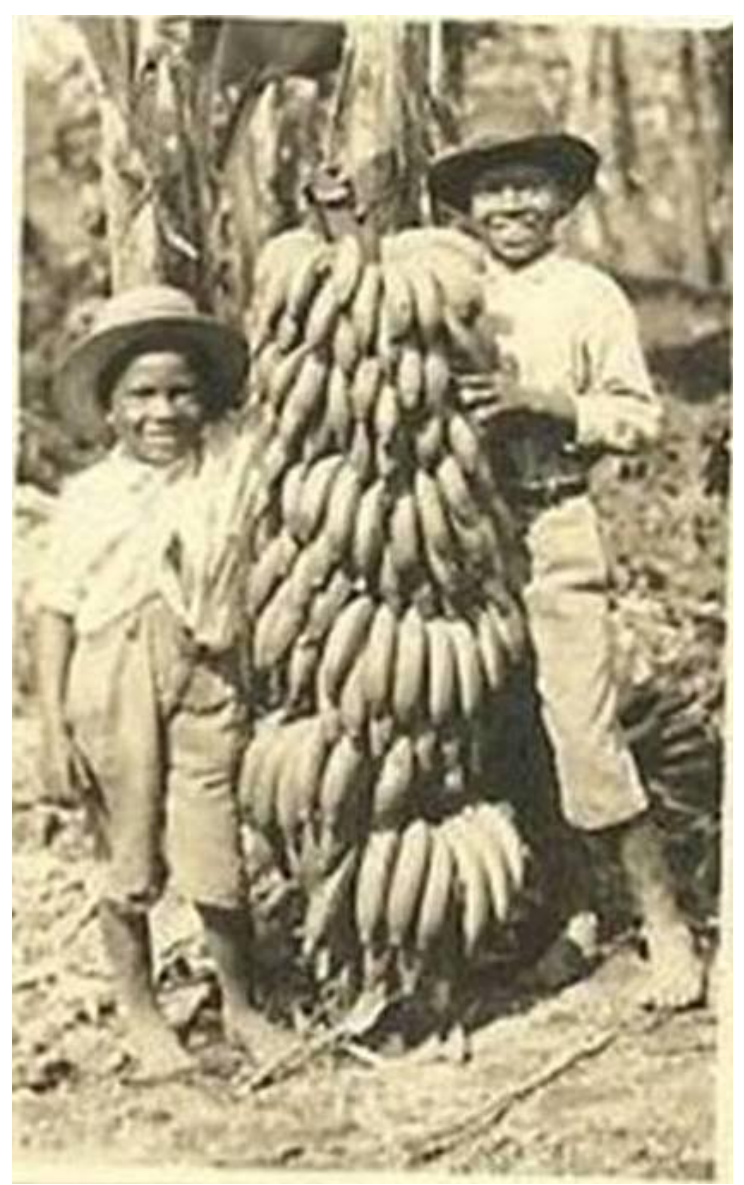

Tarjeta postal de 1930, donde se observa a dos sonrientes niños hondureños, orgullosos de posar con un racimo de bananas. En otras palabras, esta postal intentaba comunicar: ¡Esta es la tierra que produce las bananas del mundo!. 


\section{Artigo original}

Hegemonia - Revista Eletrônica do Programa de Mestrado em Direitos Humanos, Cidadania e Violência/Ciência Política do Centro Universitário Unieuro ISSN: 1809-1261

UNIEURO, Brasília, número 24, Julho a Dezembro de 2018, pp. 110-259.

\section{POSTAL 9}

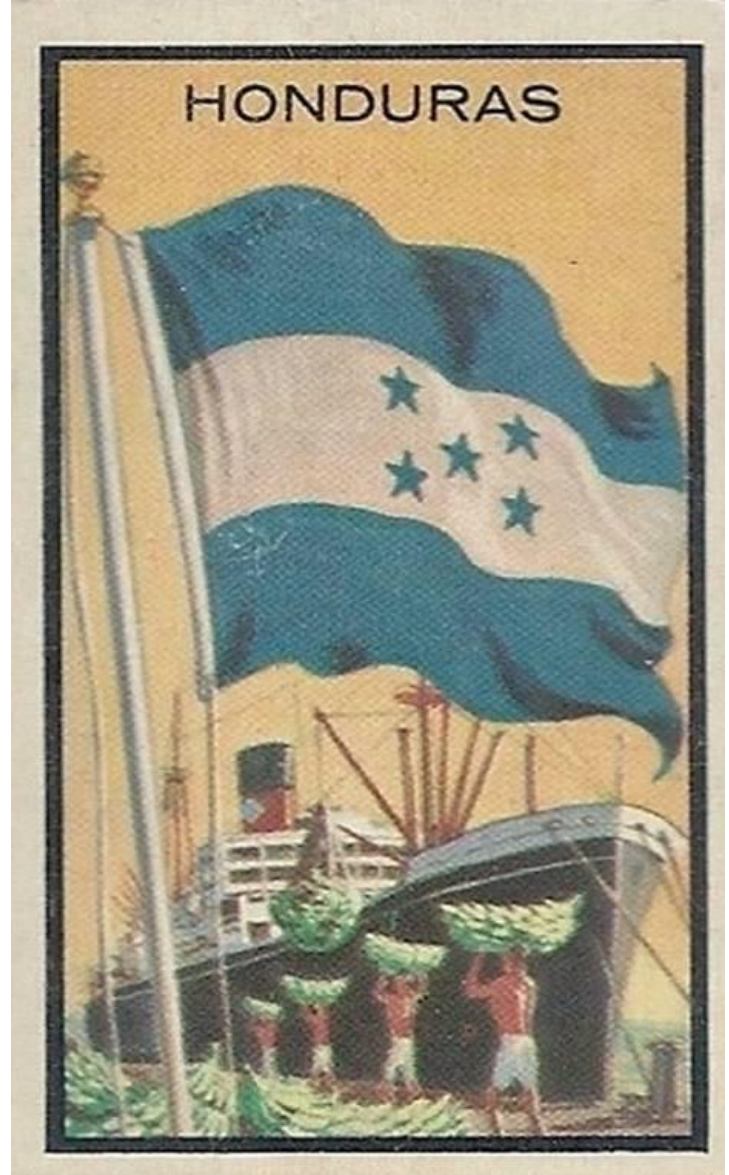

Cromo o vista publicada en España, en 1950, parte de una serie de estampas del mundo que se intercambiaban por la compra de productos, y que también circulaban como postales remitidas por correo, y que retrata explícitamente a Honduras como una "Banana Republic". Esa era sin duda la imagen más generalizada de Honduras en Europa por aquellos años. 
Artigo original

Hegemonia - Revista Eletrônica do Programa de Mestrado em Direitos Humanos, Cidadania e Violência/Ciência Política do Centro Universitário Unieuro ISSN: $1809-1261$

UNIEURO, Brasília, número 24, Julho a Dezembro de 2018, pp. 110-259.

POSTAL 10

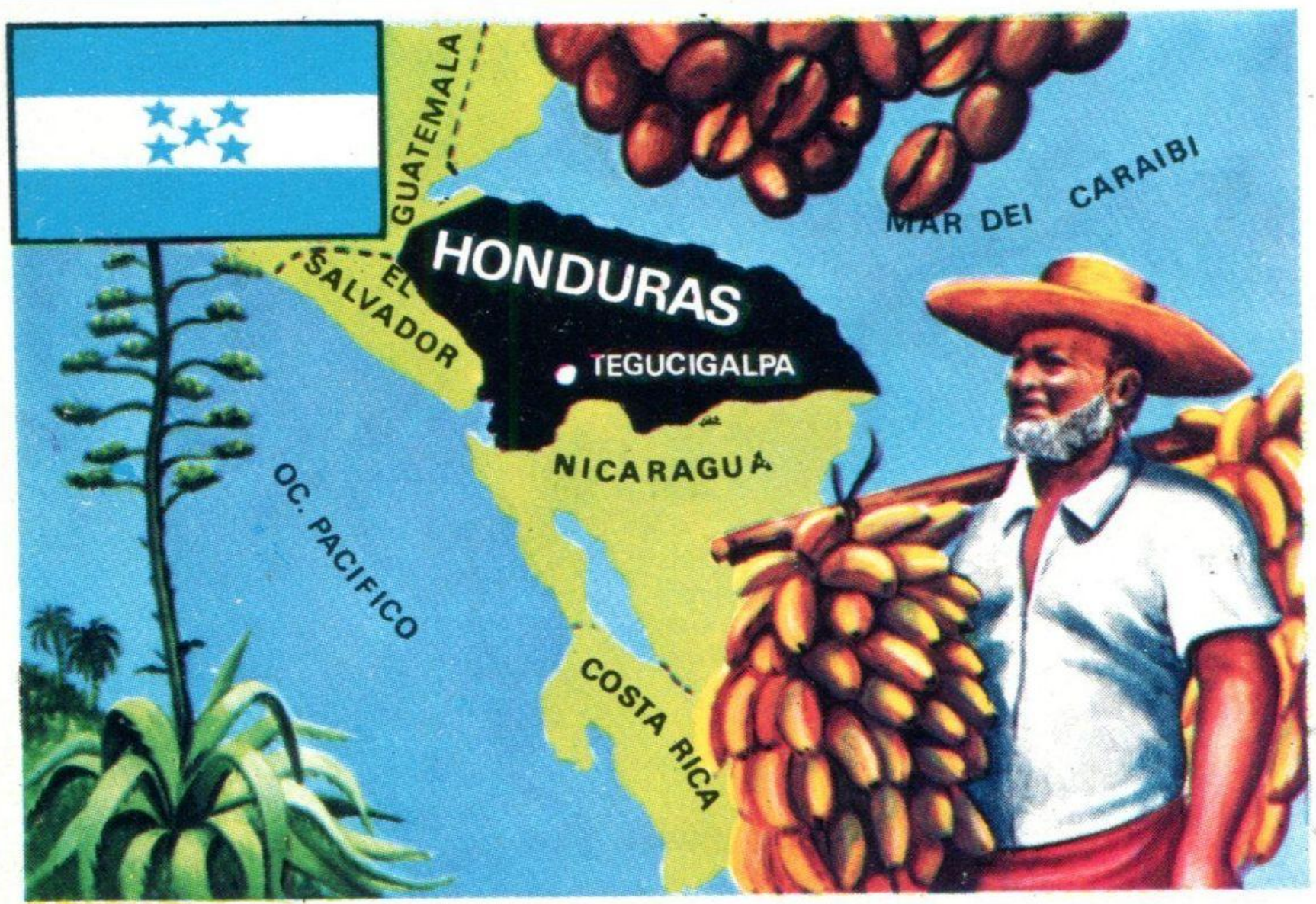

Otro cromo publicado en España en los años sesenta, que igualmente representa a Honduras como un "país bananero", además de mestizo. 


\section{Artigo original}

Hegemonia - Revista Eletrônica do Programa de Mestrado em Direitos Humanos, Cidadania e Violência/Ciência Política do Centro Universitário Unieuro ISSN: 1809-1261

UNIEURO, Brasília, número 24, Julho a Dezembro de 2018, pp. 110-259.

\section{POSTAL 11}

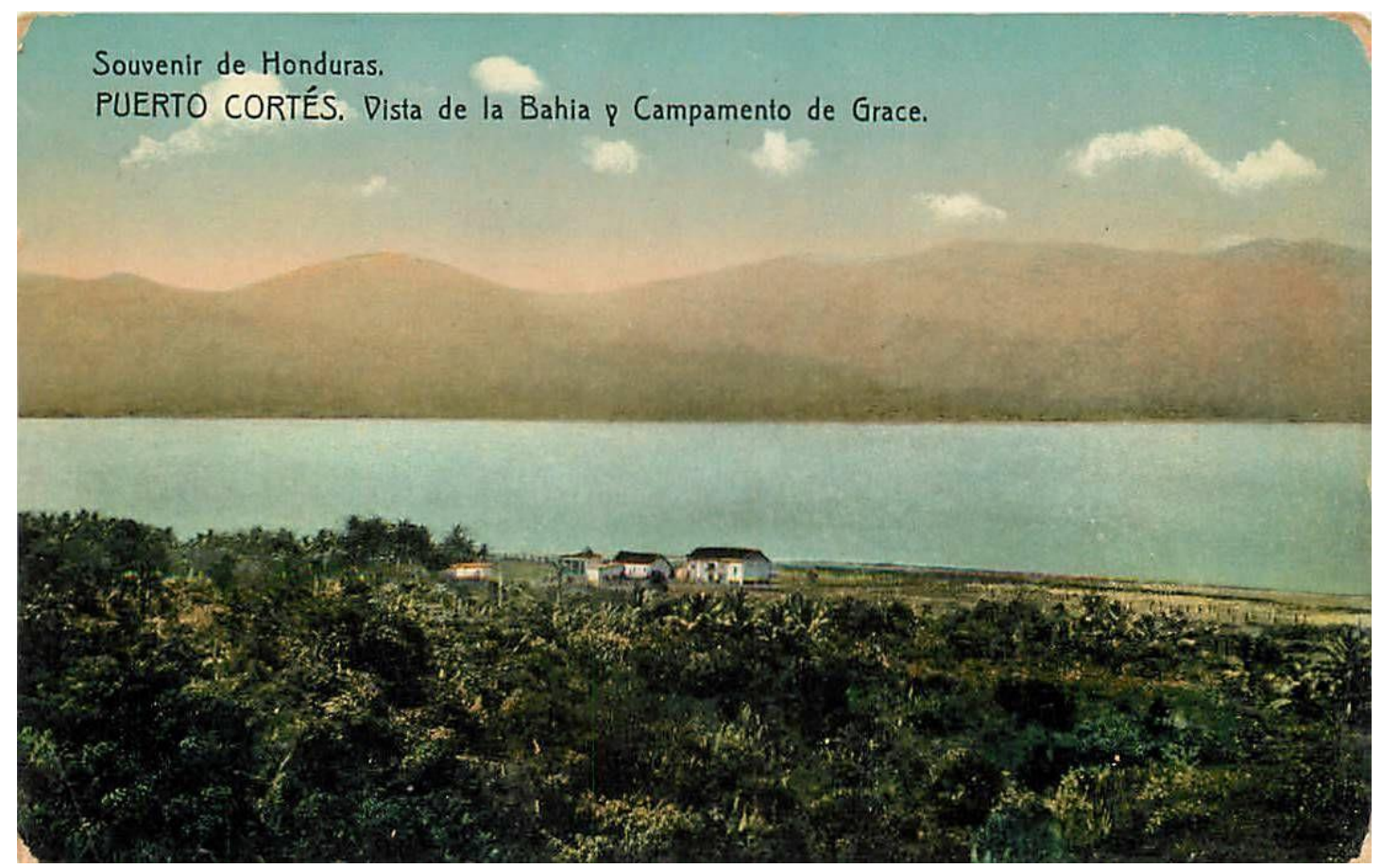

Hermosa postal coloreada, de principios del siglo XX, obra del artista fotógrafo hondureño don Rafael Ugarte, posiblemente el primer fotógrafo hondureño profesional, quien documentó el paisaje y territorio hondureño como pocos autores, y que ilustra la zona bananera de Puerto Cortés, con la vista de la Bahía y el "Campamento Grace". El exuberante paisaje, contrasta con la arquitectura de las casas de los "Company Town", al estilo norteamericano, con casas de madera y techos de zinc. Igualmente, la geografía costeña se va ampliando con toponimias gringas y anglicismos, como este "Campamento Grace". Parte de la labor de los enclaves y de la imposición de la "Banana Republic" por parte de las compañías extranjeras era producir este traslape de objetos culturales. 
Artigo original

Hegemonia - Revista Eletrônica do Programa de Mestrado em Direitos Humanos, Cidadania e Violência/Ciência Política do Centro Universitário Unieuro ISSN: $1809-1261$

UNIEURO, Brasília, número 24, Julho a Dezembro de 2018, pp. 110-259.

\section{POSTAL 12}

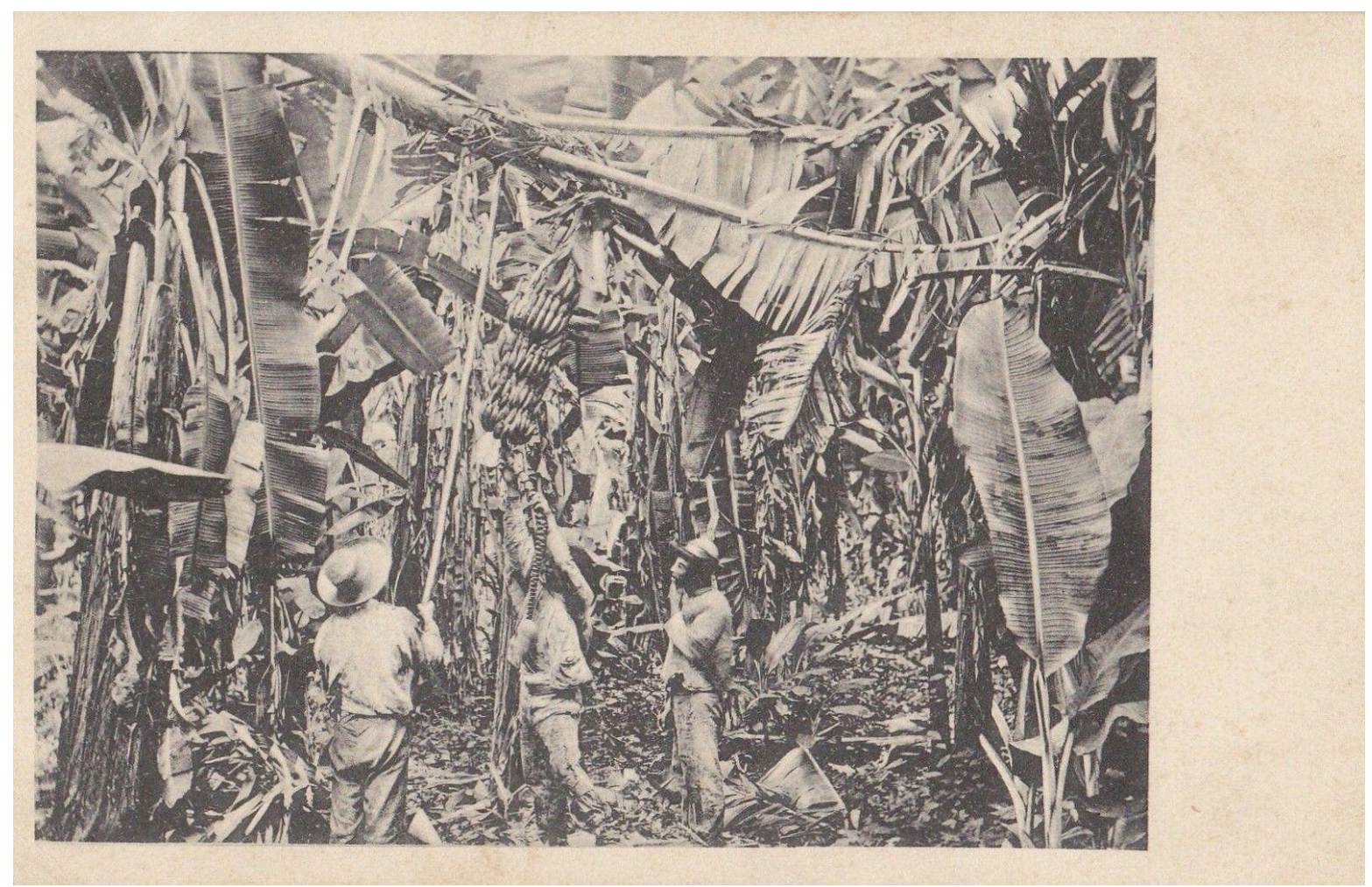

Tarjeta postal de la década de 1910, donde ya aparece una de las imágenes más recurrentes en las postales de temática bananera: el proceso de produc ción de la fruta conocida desde entonces en Honduras como "Oro verde". En este caso, se ve a obreros indígenas y afrodescendientes en la labor del corte de los racimos, para posteriormente trasladarlos a lomo de mulas o de bueyes a los vagones de los ferrocarriles, y de ahí a los muelles, y de los muelles hacia los puertos de Norteamérica y del resto del mundo. Con estas representaciones se quería dar cabal idea del racional proceso de producción implantado por las bananeras, al estilo weberiano. 
Artigo original

Hegemonia - Revista Eletrônica do Programa de Mestrado em Direitos Humanos, Cidadania e Violência/Ciência Política do Centro Universitário Unieuro ISSN: 1809-1261

UNIEURO, Brasília, número 24, Julho a Dezembro de 2018, pp. 110-259.

\section{POSTAL 13}

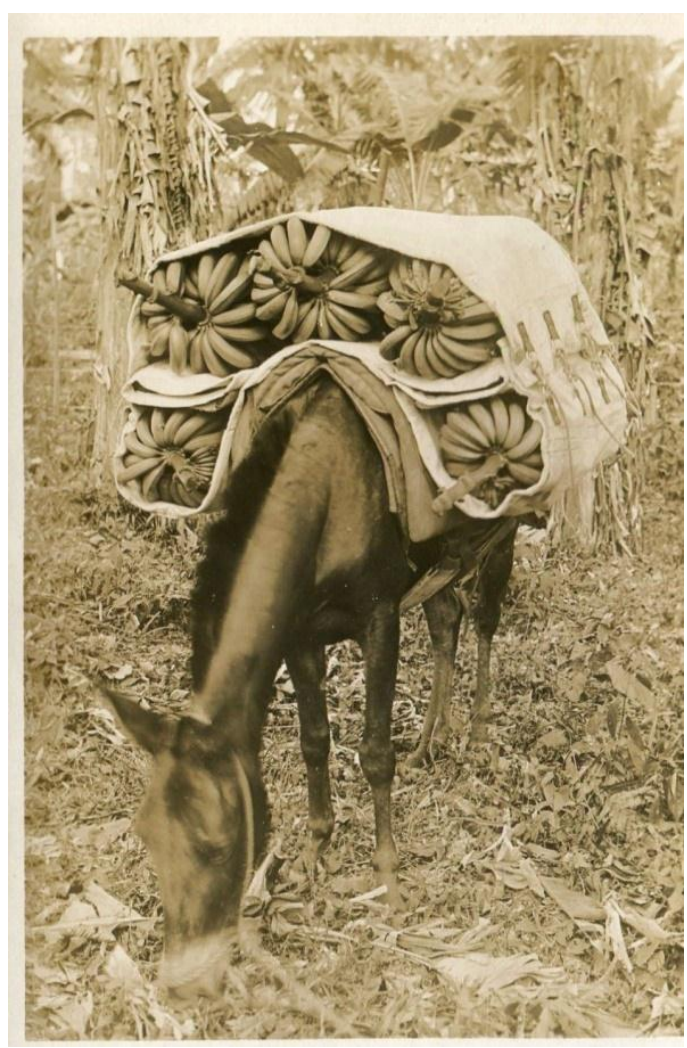

Extraordinaria y cotidiana postal de los años treinta, en que se ve a una mula cargando bananas. Esta escena que plasma algo tan sencillo como a la acémila cargando la fruta, nos da cuenta del importante papel que jugaban estos animales en el proceso de recolección y traslado de la fruta desde las fincas a los vagones de los ferrocarriles y luego a los puertos de salida. 
Artigo original

Hegemonia - Revista Eletrônica do Programa de Mestrado em Direitos Humanos, Cidadania e Violência/Ciência Política do Centro Universitário Unieuro ISSN: 1809-1261

UNIEURO, Brasília, número 24, Julho a Dezembro de 2018, pp. 110-259.

POSTAL 14

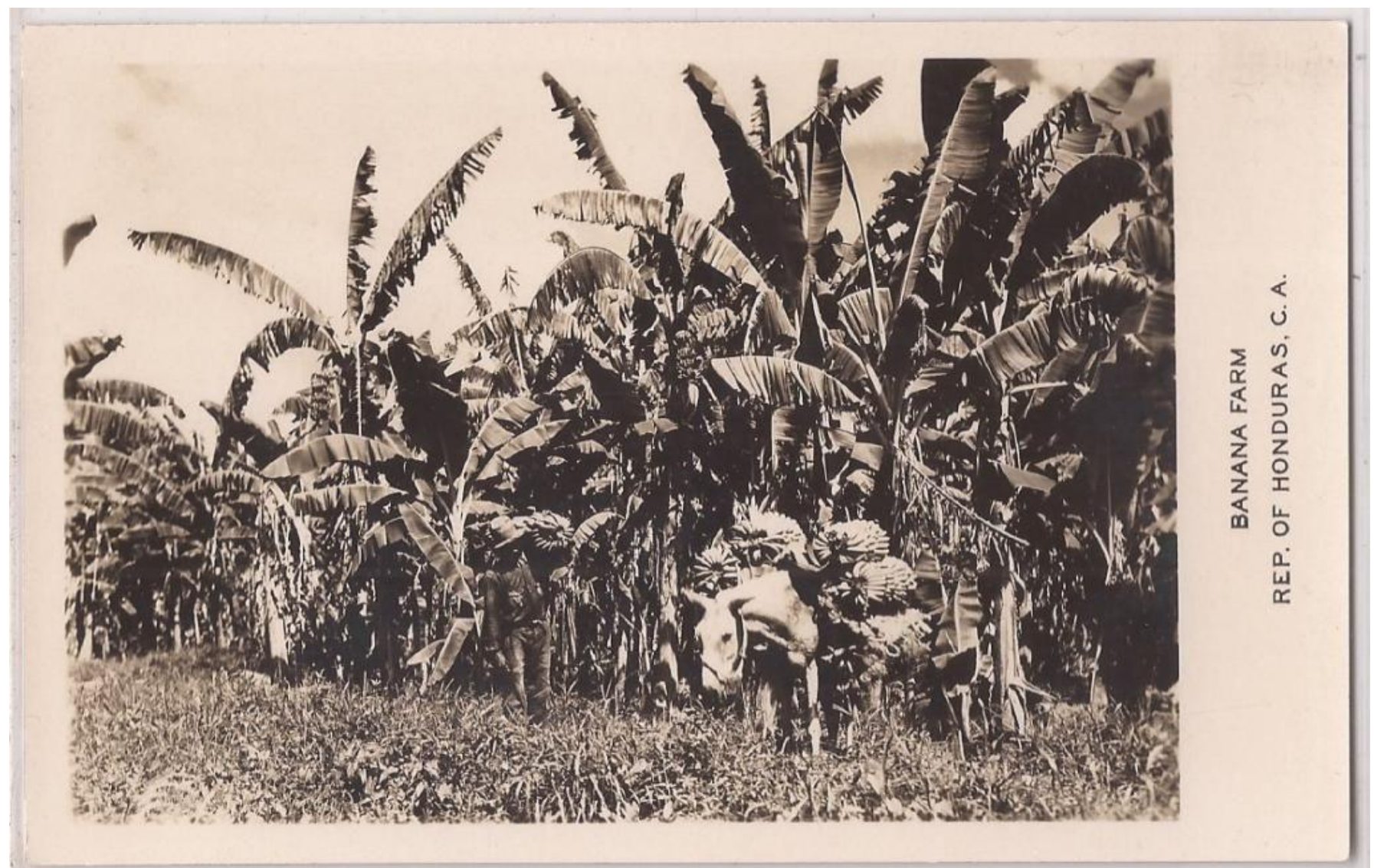

Hermosa postal de los años treinta de las series reproducidas por encargo de la "United Fruit Company", a través de sus subsidiarias la “Tela Railroad Company" y la “Truxillo Railroad Company", que ilustra a un campeño llevando sobre sus hombros un racimo de bananos para colocarlos sobre una mula, que luego trasladará el banano hacia los vagones del tren. 
Artigo original

Hegemonia - Revista Eletrônica do Programa de Mestrado em Direitos Humanos, Cidadania e Violência/Ciência Política do Centro Universitário Unieuro ISSN: $1809-1261$

UNIEURO, Brasília, número 24, Julho a Dezembro de 2018, pp. 110-259.

\section{POSTAL 15}

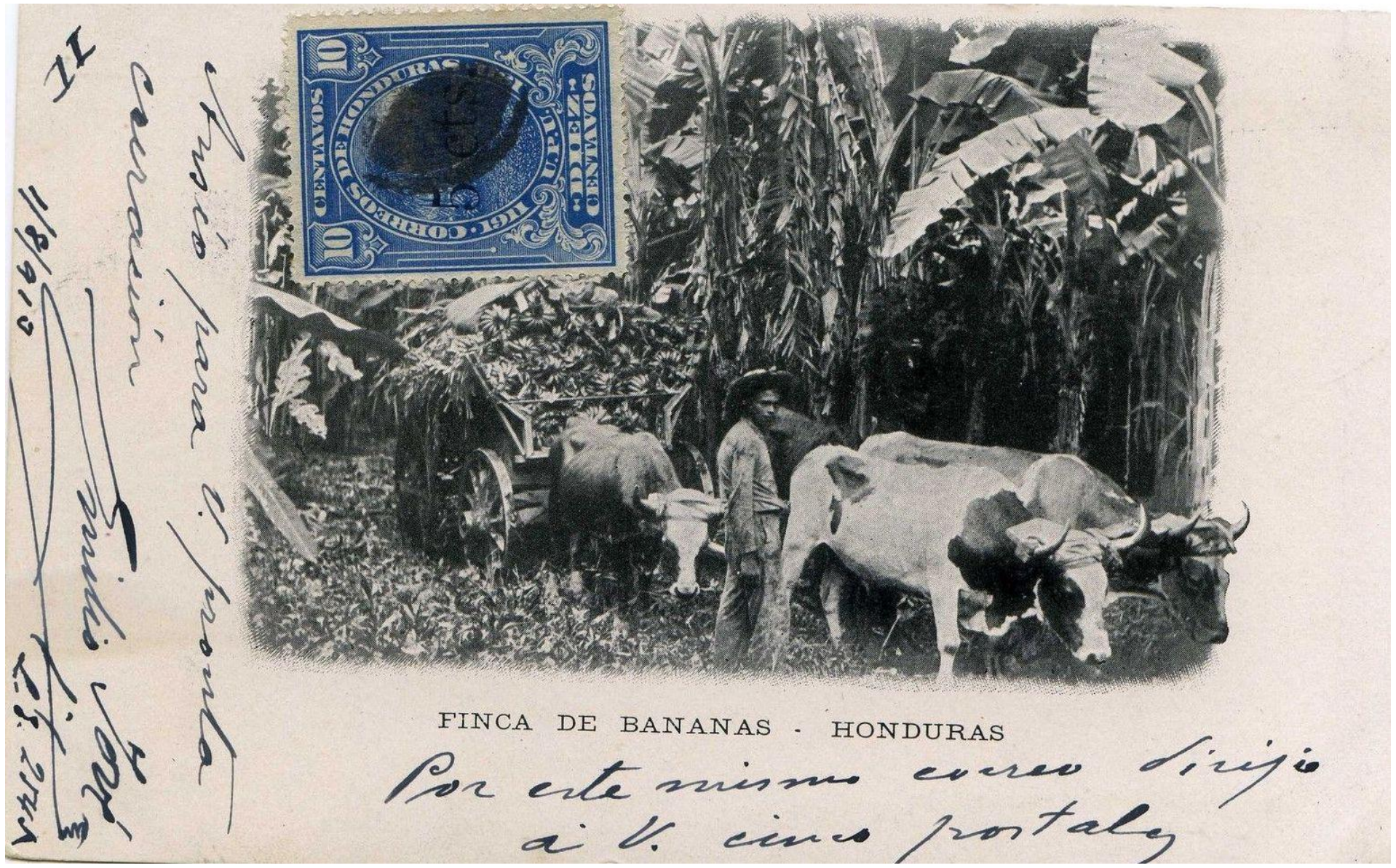

Bella postal, obra del fotógrafo alemán C. Maier -quien residió en San Pedro Sula a principios del siglo XX-, titulada "Finca de bananas-Honduras", remitida el 1 de agosto de 1910 hacia Norteamérica, con el solidario mensaje de "Ansío para su persona curación", en la que se observa a un arriero con una yunta de bueyes trasladando bananas hacia el ferrocarril, que llevará posteriormente la fruta a los muelles. 
Artigo original

Hegemonia - Revista Eletrônica do Programa de Mestrado em Direitos Humanos, Cidadania e Violência/Ciência Política do Centro Universitário Unieuro ISSN: 1809-1261

UNIEURO, Brasília, número 24, Julho a Dezembro de 2018, pp. 110-259.

\section{POSTAL 16}

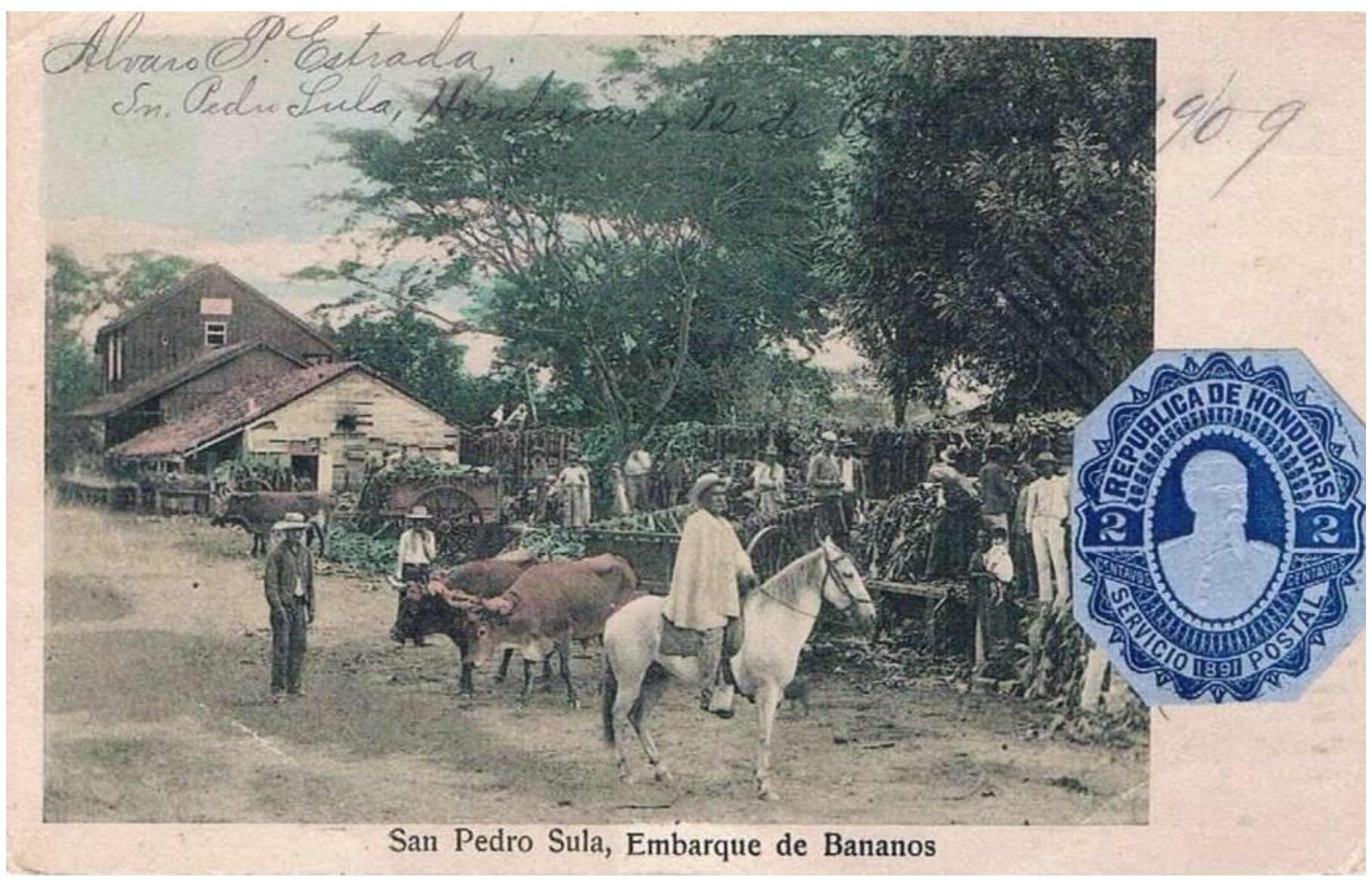

Otra interesante postal coloreada, digna de portada, remitida en 1909 por el famoso Álvaro Pérez Estrada (un importante intelectual de la época), que ilustra una finca bananera de San Pedro Sula, en donde se aprecia la arquitectura introducida en los "Company Town", así como el trabajo de los obreros, el transporte de la fruta y el trabajo de los "Mandadores de Fincas" (en el centro, montado a caballo). 
Artigo original

Hegemonia - Revista Eletrônica do Programa de Mestrado em Direitos Humanos, Cidadania e Violência/Ciência Política do Centro Universitário Unieuro ISSN: $1809-1261$

UNIEURO, Brasília, número 24, Julho a Dezembro de 2018, pp. 110-259.

POSTAL 17

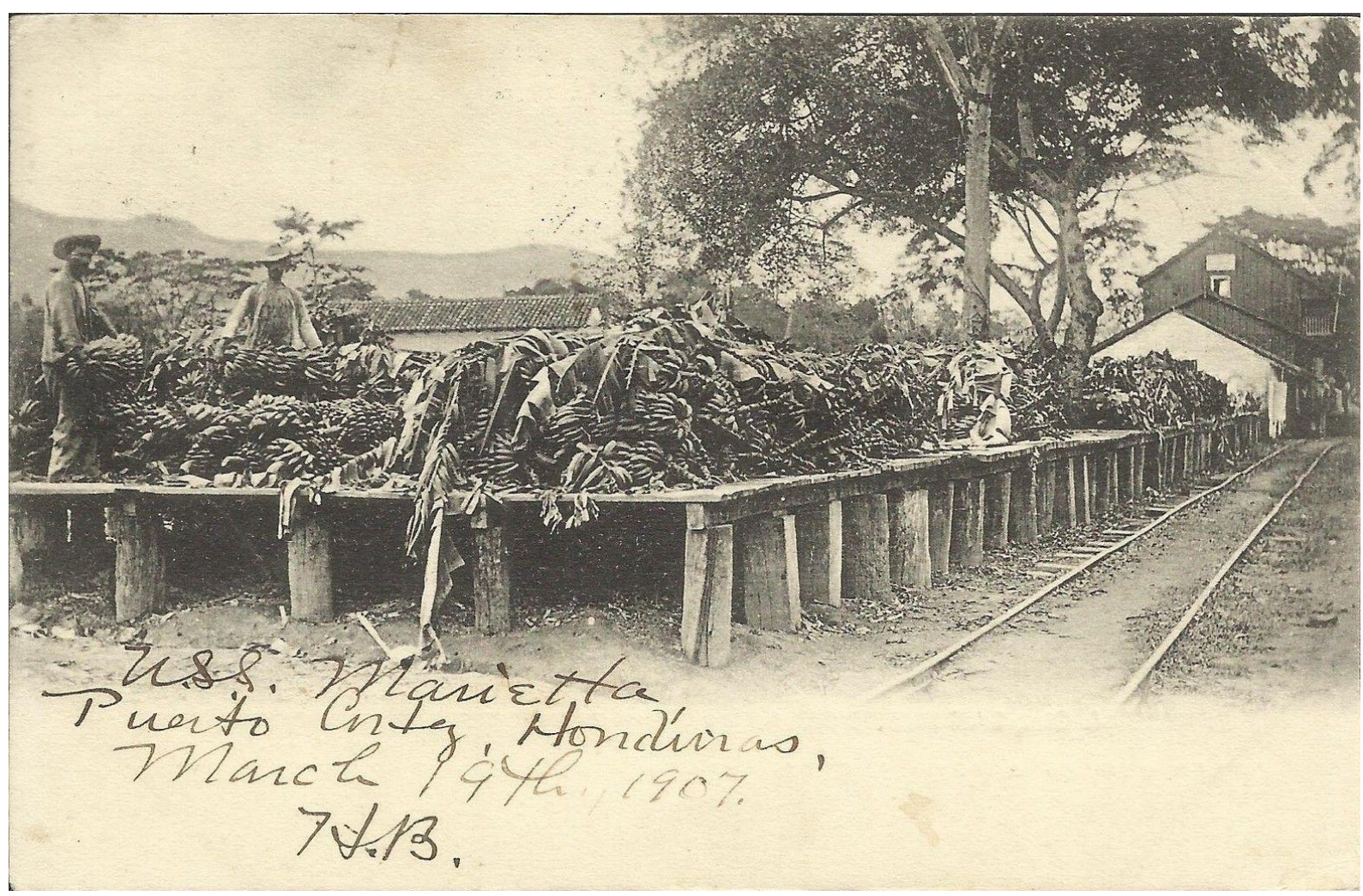

Postal de 1907, editada por el artista fotógrafo J. A. Doubleday, un importante artista visual que vivió en Honduras durante las dos primeras décadas del siglo XX, posiblemente uno de los principales documentalistas de la región bananera de Honduras, que ilustra una escena más del proceso productivo de las bananeras: un par de obreros juntando, ordenando y clasificando los racimos de bananos junto a la vía del ferrocarril en Puerto Cortés, que luego serán embalados y subidos al muelle para ser exportados. 
Artigo original

Hegemonia - Revista Eletrônica do Programa de Mestrado em Direitos Humanos, Cidadania e Violência/Ciência Política do Centro Universitário Unieuro ISSN: $1809-1261$

UNIEURO, Brasília, número 24, Julho a Dezembro de 2018, pp. 110-259.

POSTAL 18

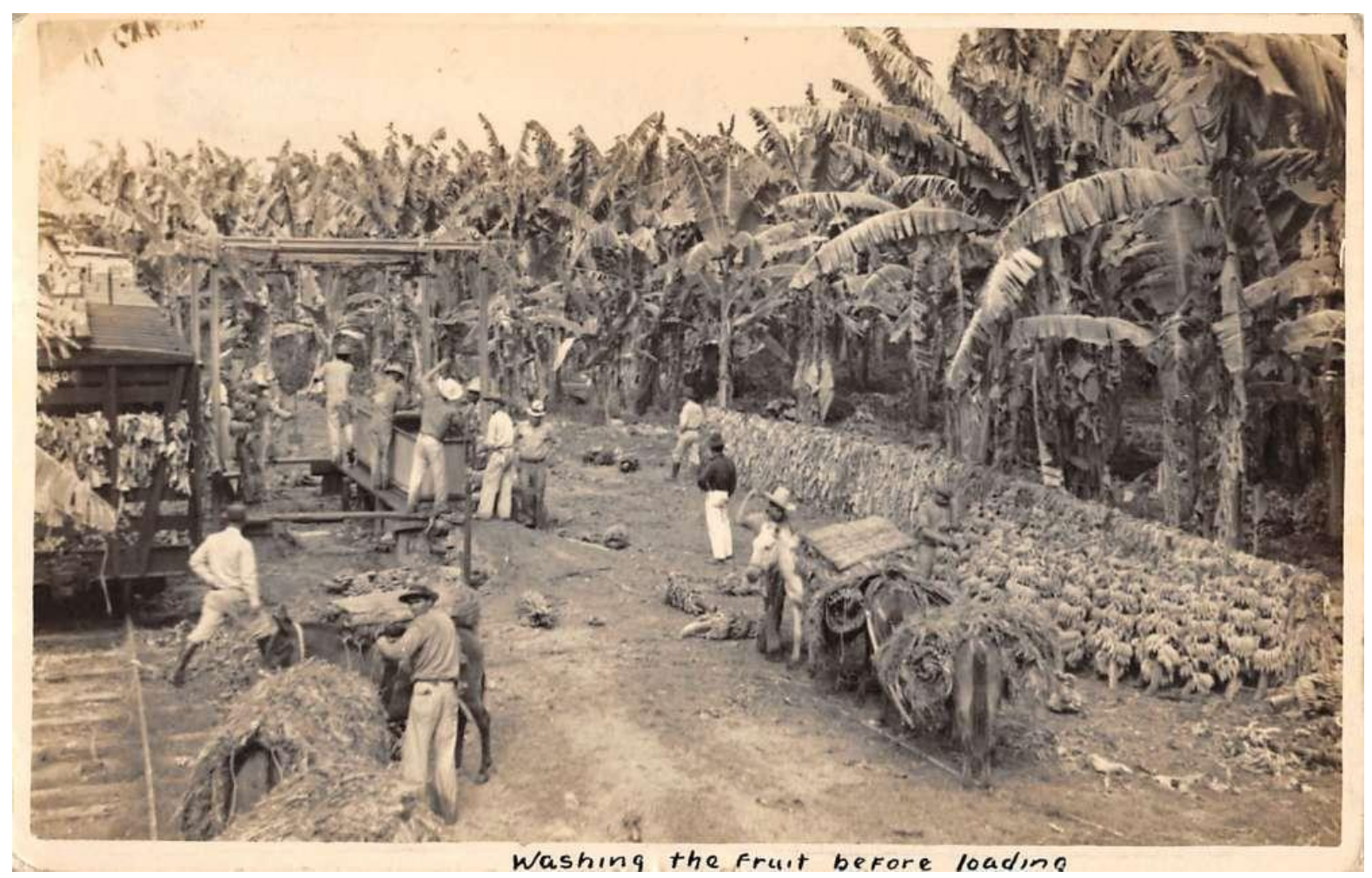

Otra sugestiva postal de los años veinte, titulada "Washinf the Fruit Before Loading”, que muestra otras interesantes facetas del proceso productivo que fue innovando la compañía bananera: además del trabajo de los obreros y de las mulas, se ve también un sistema más mecanizado -al estilo del fordismo- con la introducción de sistemas mecánicos de cables, llamados "Cable vías", para el traslado de los bananos a los ferrocarriles, con el fin de que la fruta se dañara menos y se incrementaran los estándares de calidad del banano. 
Artigo original

Hegemonia - Revista Eletrônica do Programa de Mestrado em Direitos Humanos, Cidadania e Violência/Ciência Política do Centro Universitário Unieuro ISSN: $1809-1261$

UNIEURO, Brasília, número 24, Julho a Dezembro de 2018, pp. 110-259.

POSTAL 19

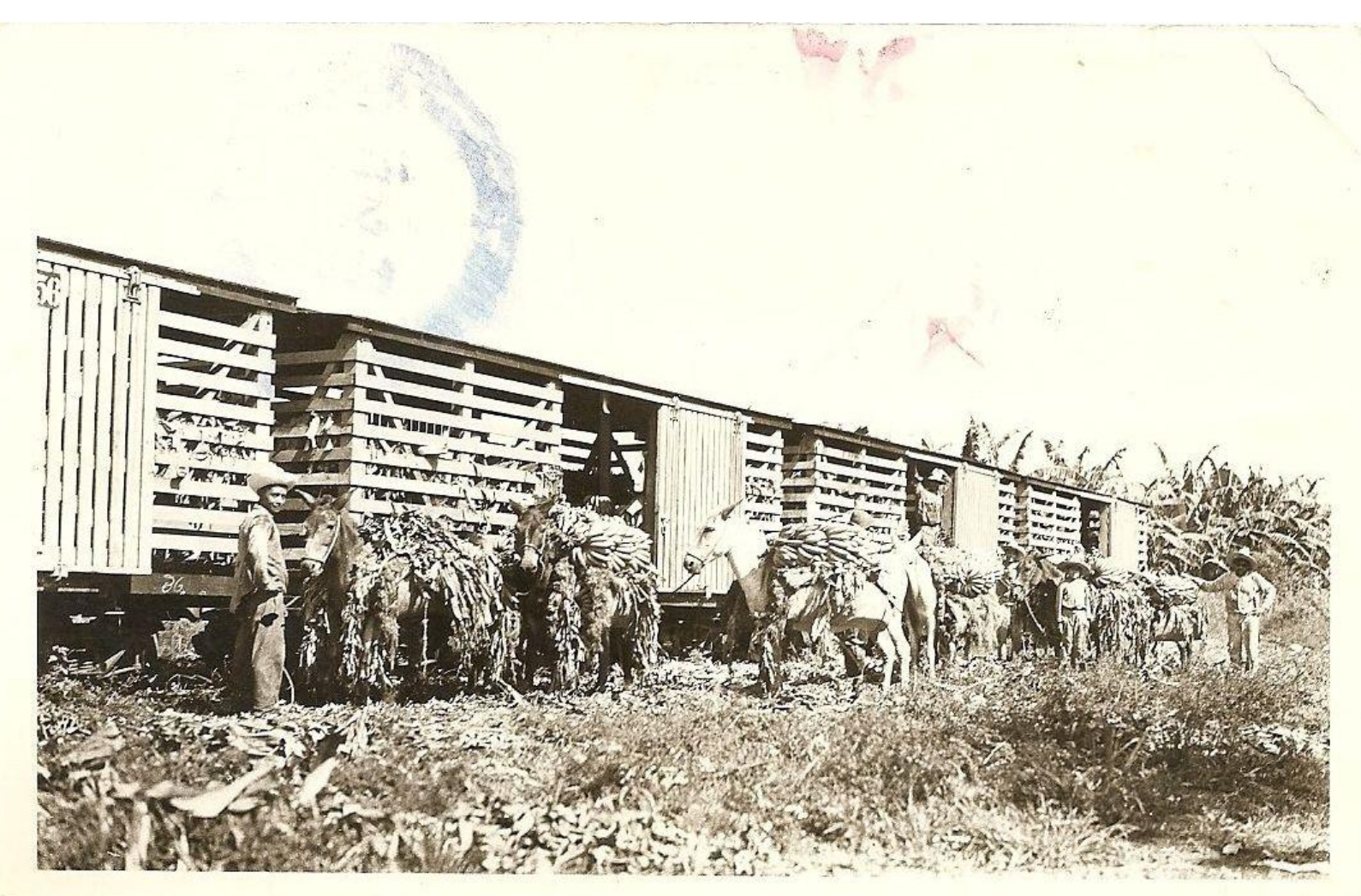

Postal de los años treinta, editada como parte de las series de la "UFCO" que ya hemos citado antes, que detalla el importante momento en que un obrero "mulero" lleva la fruta hasta los vagones del ferrocarril, para luego ser trasladados a los muelles. Como se ve, el proceso era largo y complejo, pero a la vez rápido y eficiente, tal como el capitalismo industrial de la época exigía para la satisfacer la demanda mundial. Este proceso incorporó de lleno al país en la dinámica capitalista mundial, pero bajo el régimen de economía de enclave. 
Artigo original

Hegemonia - Revista Eletrônica do Programa de Mestrado em Direitos Humanos, Cidadania e Violência/Ciência Política do Centro Universitário Unieuro ISSN: 1809-1261

UNIEURO, Brasília, número 24, Julho a Dezembro de 2018, pp. 110-259.

POSTAL 20

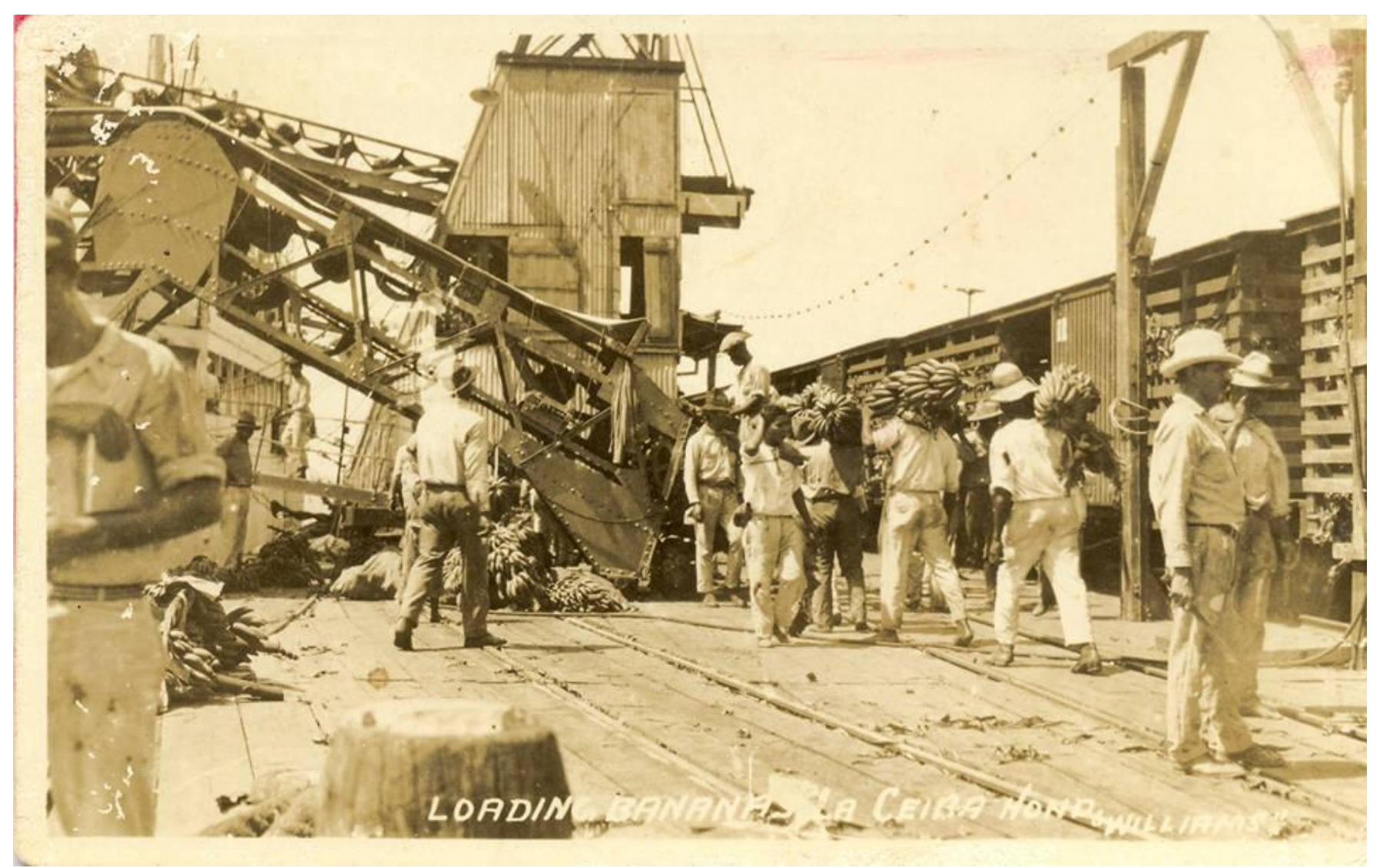

Espectacular postal de 1930, del fotógrafo Williams, ya citado antes, que retrata con lujo uno de los momentos más relevantes del ciclo productivo de las bananeras: la llegada de los ferrocarriles con la fruta al muelle, y el traslado de los racimos por obreros especializados, los famosos "muelleros", que cargan a lomo y pasan la fruta de los vagones a los barcos anclados en el puerto, las legendarias embarcaciones conocidas como "la Gran Flota Blanca". 
Artigo original

Hegemonia - Revista Eletrônica do Programa de Mestrado em Direitos Humanos, Cidadania e Violência/Ciência Política do Centro Universitário Unieuro ISSN: 1809-1261

UNIEURO, Brasília, número 24, Julho a Dezembro de 2018, pp. 110-259.

POSTAL 21

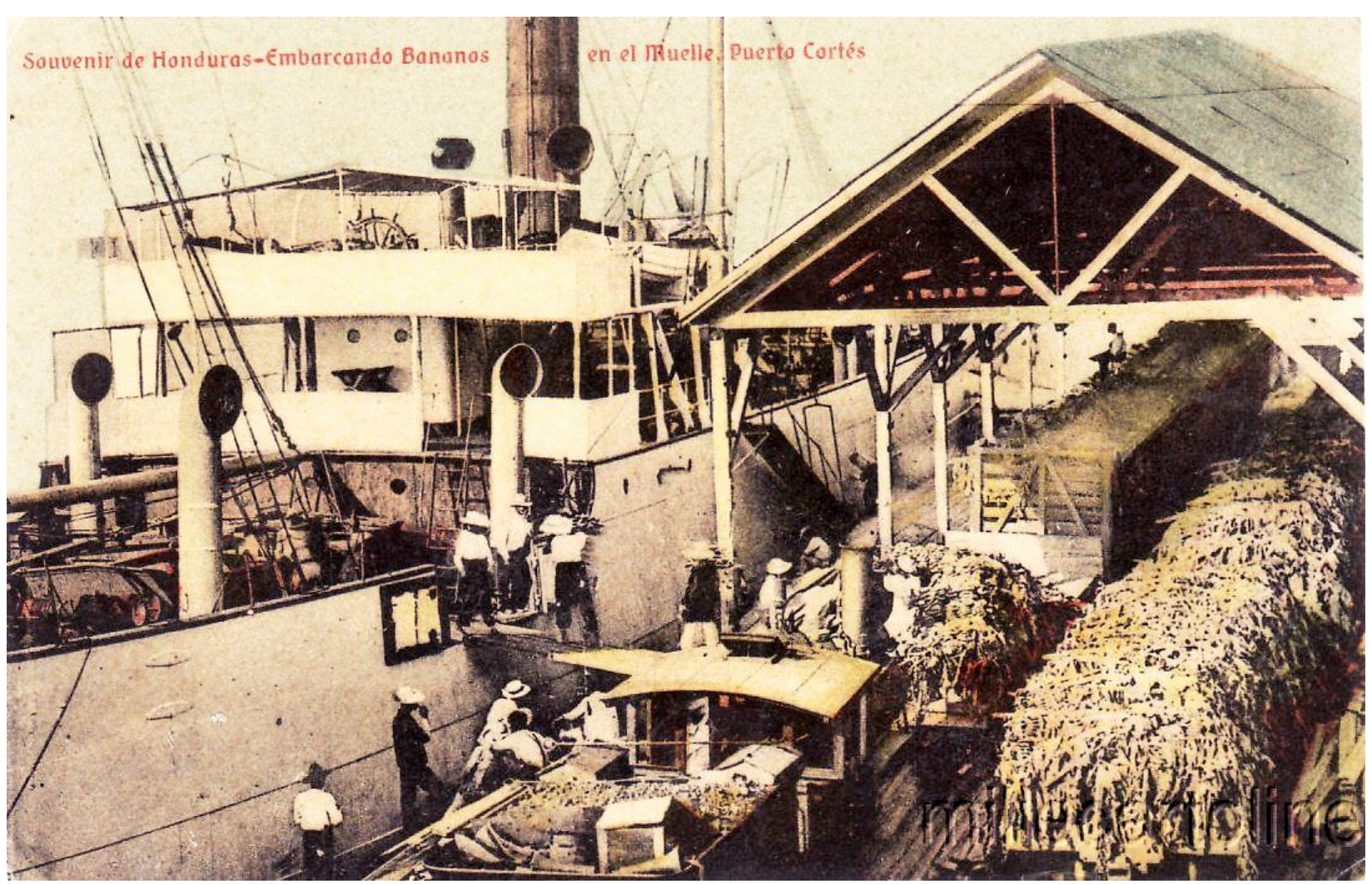

Fascinante postal coloreada de los años veinte, titulada "Souvenir de Honduras: embarcando bananas en el muelle de Puerto Cortés", que ilustra el proceso de embarques de bananos en las galeras y bodegas de los colosales barcos de la "Gran Flota Blanca". Nótese que las racimos aún no se empacaban en las cajas de hoy en día, sino que iban embalados para su protección con matas secas del mismo banano. 


\section{Artigo original}

Hegemonia - Revista Eletrônica do Programa de Mestrado em Direitos Humanos, Cidadania e Violência/Ciência Política do Centro Universitário Unieuro ISSN: $1809-1261$

UNIEURO, Brasília, número 24, Julho a Dezembro de 2018, pp. 110-259.

\section{POSTAL 22}

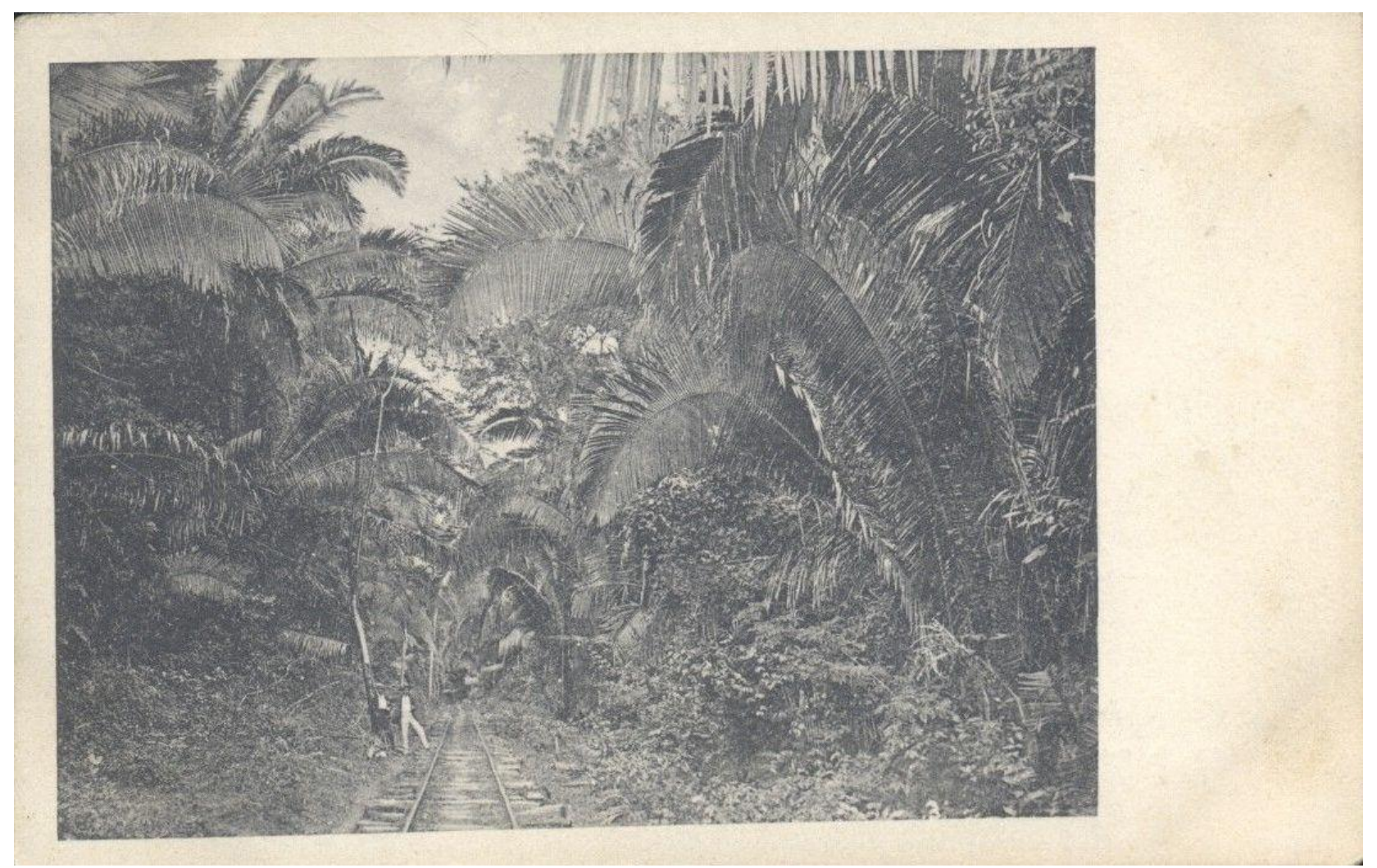

Esta postal, obra del alemán C. Maier, de 1915, titulada "Jungle of Honduras", es un testimonio elocuente de la construcción del imaginario de "Banana Republic" a través de las tarjetas postales. En este caso, como se ve, el artista fotógrafo en una toma amplia y panorámica, intenta destacar en primer lugar el imponente paisaje de la selva, la cual es "vencida" por la llegada de las líneas férreas del ferrocarril y por tanto del pujante capitalismo de las compañías fruteras; en contraposición, los dos personajes masculinos aparecen empequeñecidos ante la frondosidad de la manigua y los bananales. 
Artigo original

Hegemonia - Revista Eletrônica do Programa de Mestrado em Direitos Humanos, Cidadania e Violência/Ciência Política do Centro Universitário Unieuro ISSN: $1809-1261$

UNIEURO, Brasília, número 24, Julho a Dezembro de 2018, pp. 110-259.

POSTAL 23

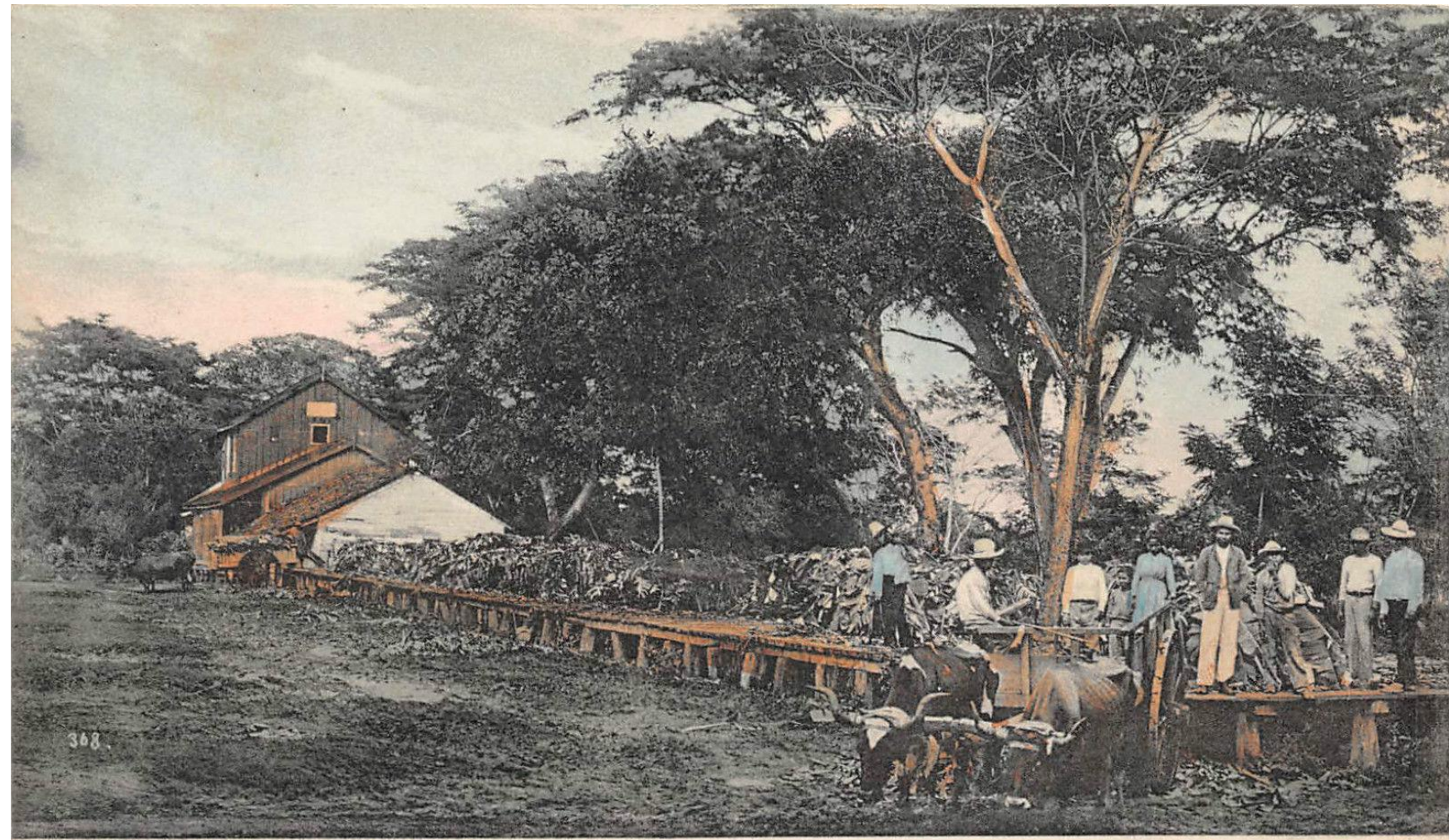

ACARREO DE BANANOS. - SAN PEDRO SULA. HONDURAS.

Editor: R. Ugarte. Foto.

Postal coloreada, obra del artista fotógrafo hondureño don Rafael Ugarte, titulada "Acarreo de bananos", en la que un grupo de campeños posan viendo a la cámara mientras preparan una yunta de bueyes para trasladar los bananos. Ugarte testimonia con estas fotos perfectamente arregladas y planificadas por el artista, la vida cotidiana de los obreros en las fincas bananeras. 
Artigo original

Hegemonia - Revista Eletrônica do Programa de Mestrado em Direitos Humanos, Cidadania e Violência/Ciência Política do Centro Universitário Unieuro ISSN: $1809-1261$

UNIEURO, Brasília, número 24, Julho a Dezembro de 2018, pp. 110-259.

\section{POSTAL 24}

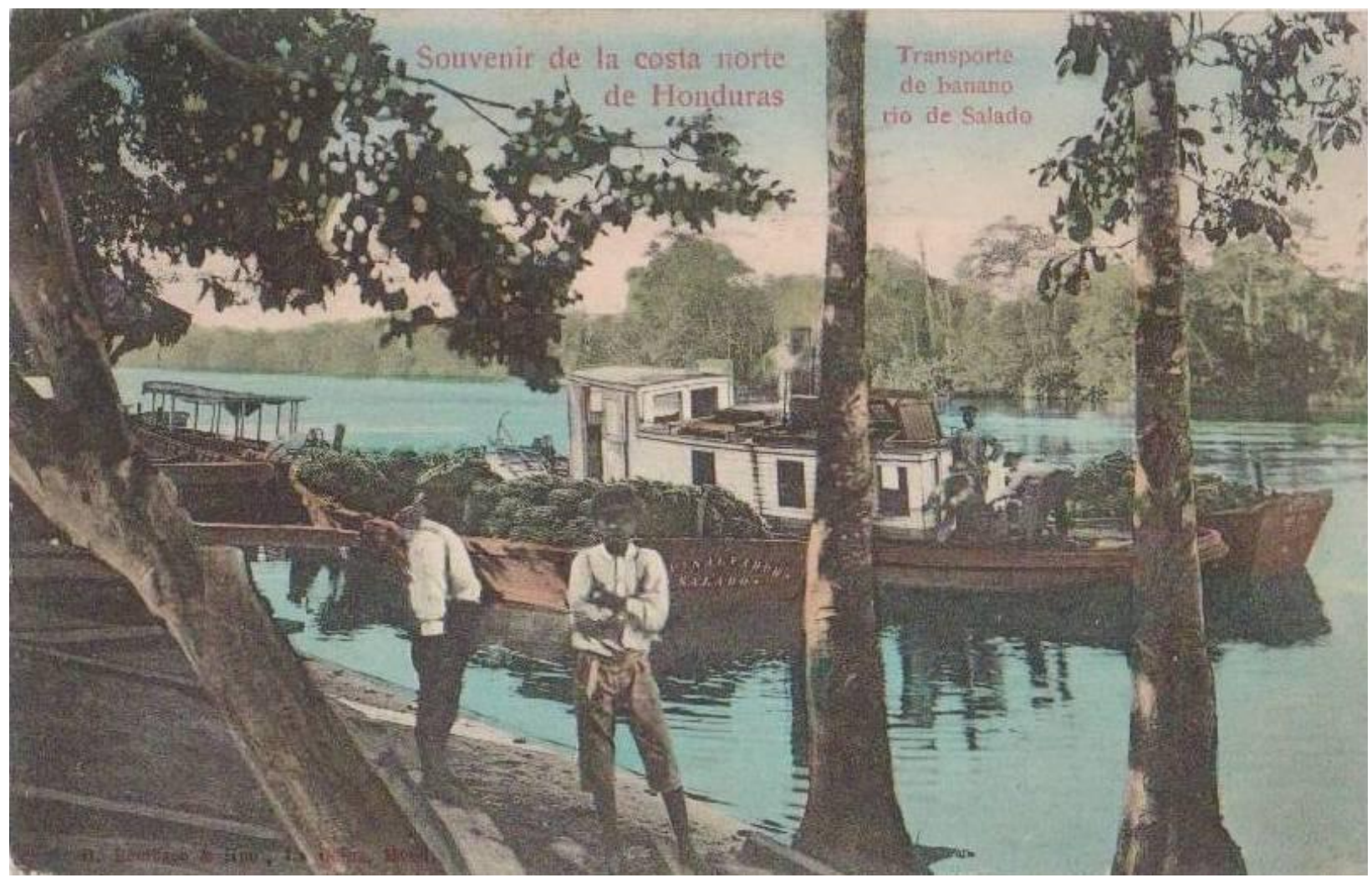

Un par de niños posiblemente Garífunas, posan con garbo en esta hermosa postal coloreada, editada por E. Bombace \& Hno., un inmigrante de origen italiano que se afincó en La Ceiba que fundó una casa comercial llamada "Bazar Italiano", y que publicó una amplia gama de postales del mundo bananero de la ciudad de La Ceiba, centro neurálgico de la "Standard Fruit Company". En este caso, se destaca el traslado de bananos que se hacía en esa región a través de ríos y canales, como se aprecian las goletas acarreando los bananos a través del Río Cuero y Salado, hoy en día un importante parque natural y refugio de vida silvestre de la zona. 
Artigo original

Hegemonia - Revista Eletrônica do Programa de Mestrado em Direitos Humanos, Cidadania e Violência/Ciência Política do Centro Universitário Unieuro ISSN: $1809-1261$

UNIEURO, Brasília, número 24, Julho a Dezembro de 2018, pp. 110-259.

POSTAL 25

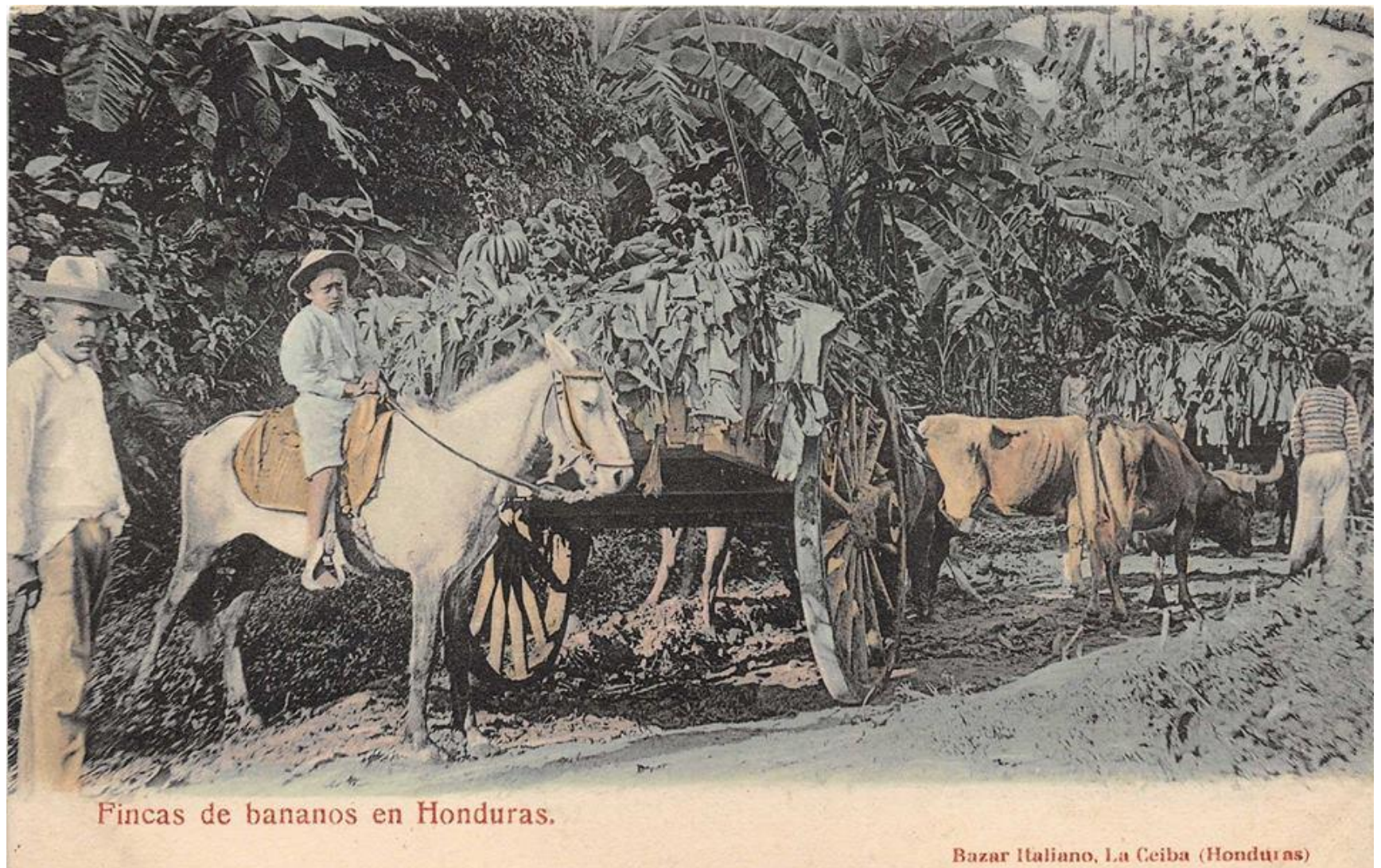

Otra bella postal, digna de una portada, editada por E. Bombace \& Hno., titulada "Finca de bananos en Honduras", en donde se aprecia en primer plano a un niño montando brioso un caballo junto al encargado de conducir las cargas de bananos en las carretas tiradas por bueyes (posiblemente el padreo abuelo del niño); esta estampa evidentemente fue "montada" al efecto por el artista fotógrafo, con el fin de ilustrar la parte del sistema de acarreos y las condiciones de trabajo de los campeños. 
Artigo original

Hegemonia - Revista Eletrônica do Programa de Mestrado em Direitos Humanos, Cidadania e Violência/Ciência Política do Centro Universitário Unieuro ISSN: 1809-1261

UNIEURO, Brasília, número 24, Julho a Dezembro de 2018, pp. 110-259.

\section{POSTAL 26}

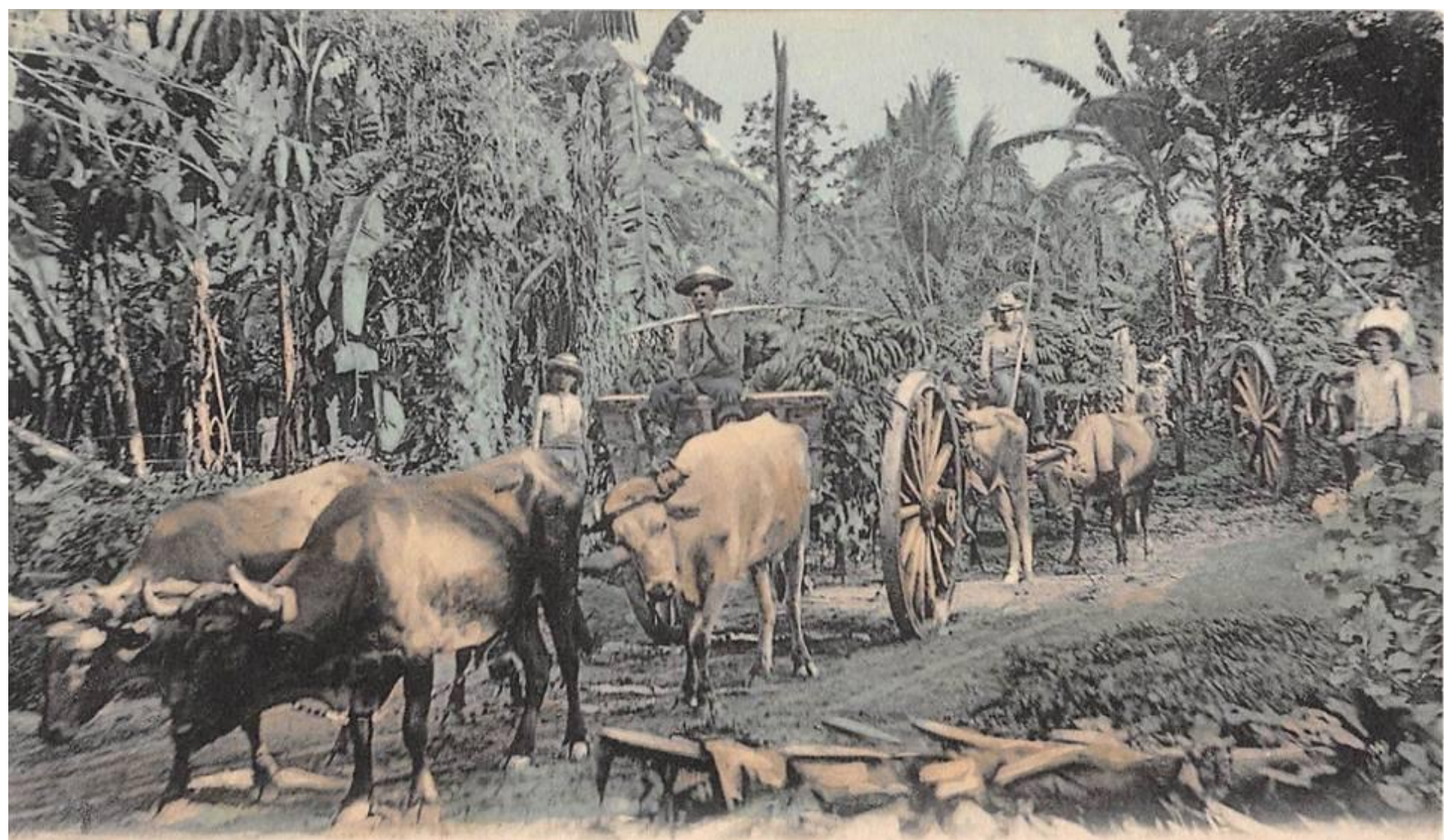

Pinca de bananos en Honduras.

Bnzar Italiano, La Ceiba (Honduraa)

Otra postal similar a las anteriores editada por H. Bombace \& y Hno., que retrata el arduo trabajo del acarreo de bananos a través de los senderos de las fincas bananeras por medio de carretas tiradas por bueyes. 
Artigo original

Hegemonia - Revista Eletrônica do Programa de Mestrado em Direitos Humanos, Cidadania e Violência/Ciência Política do Centro Universitário Unieuro ISSN: 1809-1261

UNIEURO, Brasília, número 24, Julho a Dezembro de 2018, pp. 110-259.

POSTAL 27

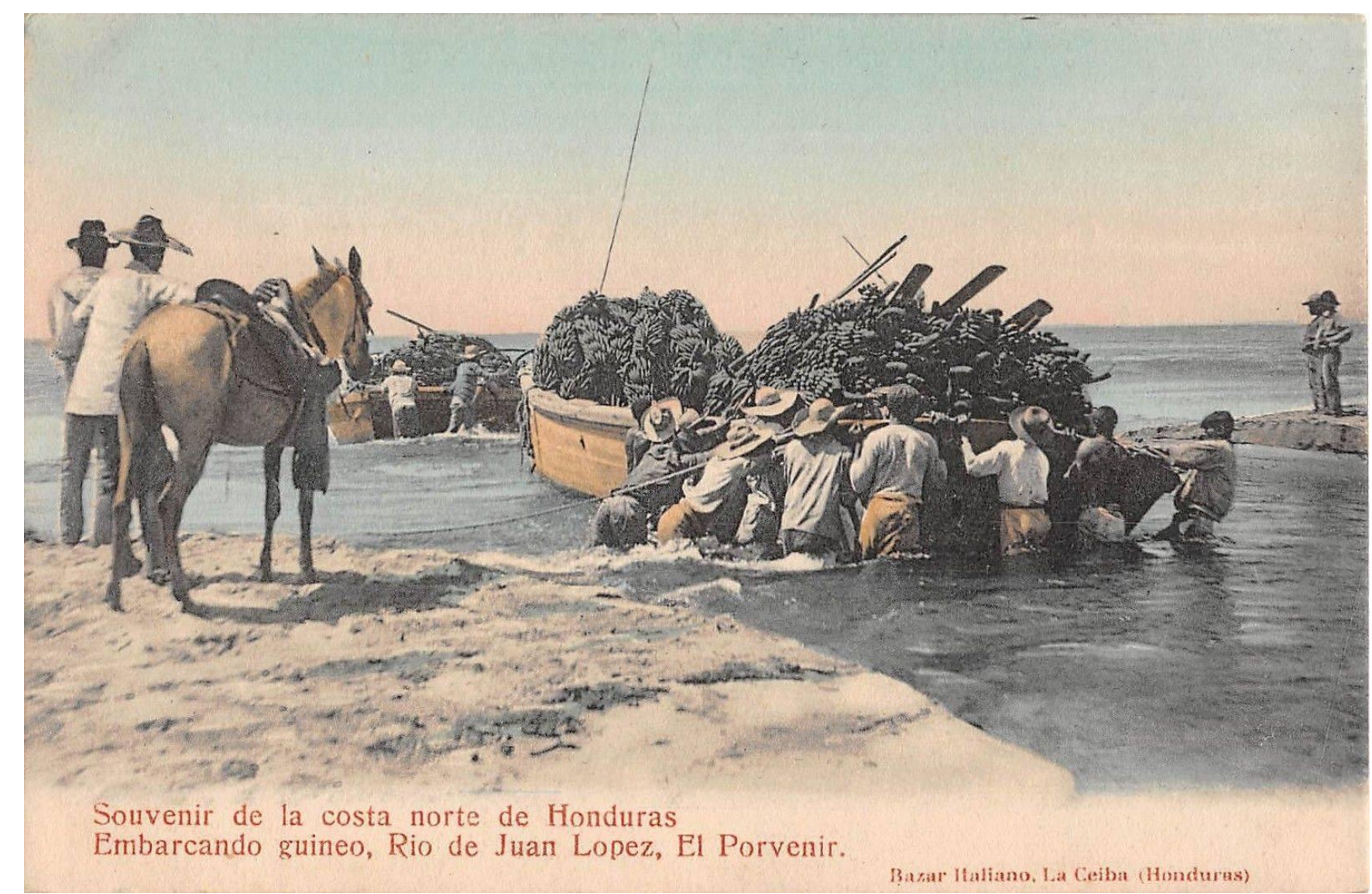

Otra postal más de la serie editada por E. Bombace \& Hno., en la que se ilustra el complicado trabajo que implicaba la llegada de los bananos a las costas. Como se ve, una vez que los bananos eran acarreados desde las fincas y llegaban a la playa, en ocasiones era necesario subirlos en lanchas y desde ahí llevarlos a los barcos que no podían atracar en puerto debido a las temporadas de lluvias. 
Artigo original

Hegemonia - Revista Eletrônica do Programa de Mestrado em Direitos Humanos, Cidadania e Violência/Ciência Política do Centro Universitário Unieuro ISSN: $1809-1261$

UNIEURO, Brasília, número 24, Julho a Dezembro de 2018, pp. 110-259.

\section{POSTAL 28}

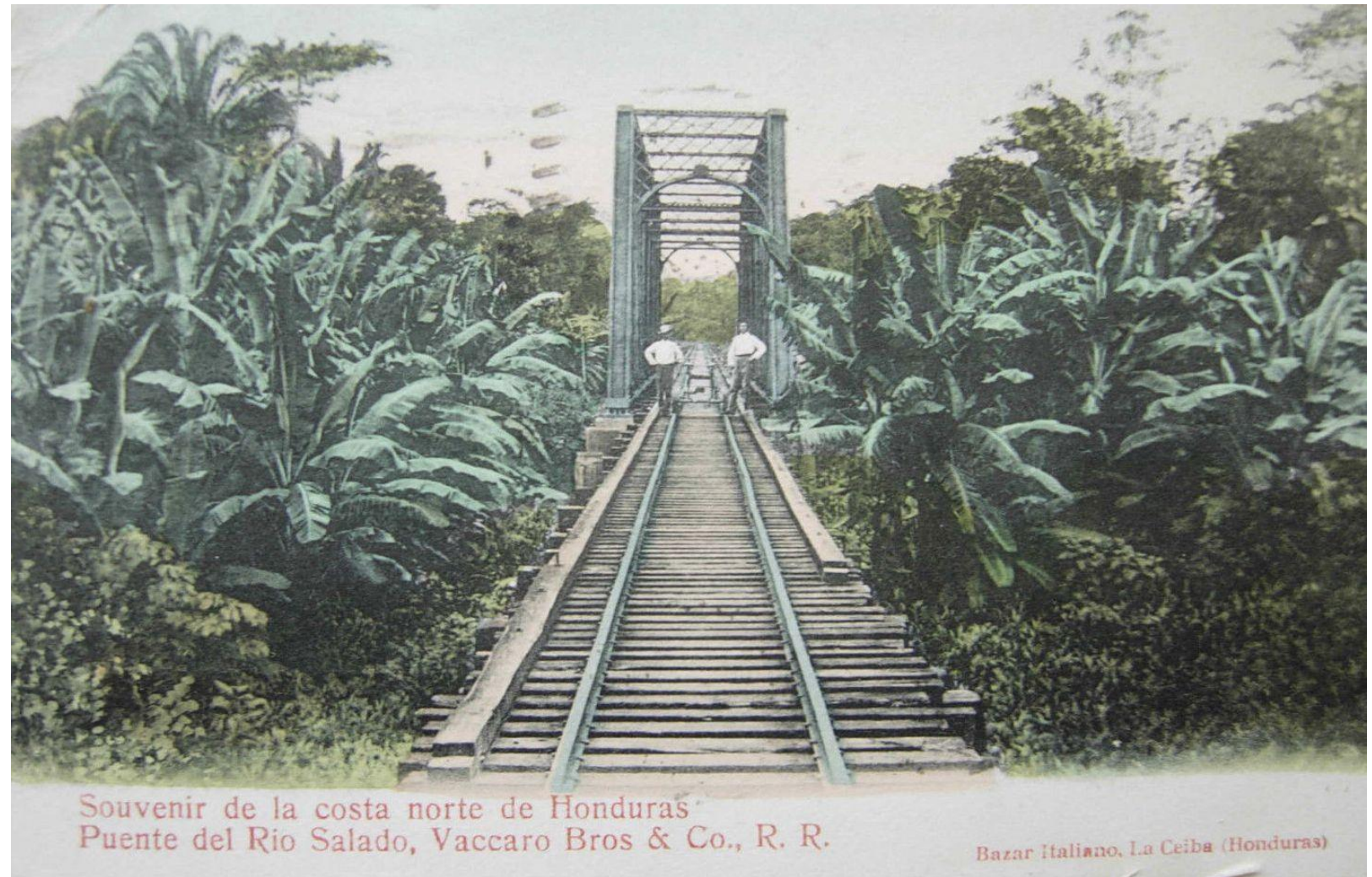

Interesante postal coloreada editada por el "Bazar Italiano" de La Ceiba, que ilustra en primer plano un puente de hierro sobre el cual posan un par de trabajadores de la "Vaccaro Brother Company", posteriormente conocida como "Standard Fruit Company", y a las orillas las extensas plantaciones de bananos. La llegada de los ferrocarriles y de los puentes de hierro, símbolos principales de la Revolución Industrial, marcaron parte de la llegada de la Modernidad a Honduras, y ese mensaje era relevante expresarlo por medio de tarjetas postales que mostraran la pujanza de las compañías fruteras y la instalación del mito de la "Banana Republic". 
Artigo original

Hegemonia - Revista Eletrônica do Programa de Mestrado em Direitos Humanos, Cidadania e Violência/Ciência Política do Centro Universitário Unieuro ISSN: 1809-1261

UNIEURO, Brasília, número 24, Julho a Dezembro de 2018, pp. 110-259.

\section{POSTAL 29}

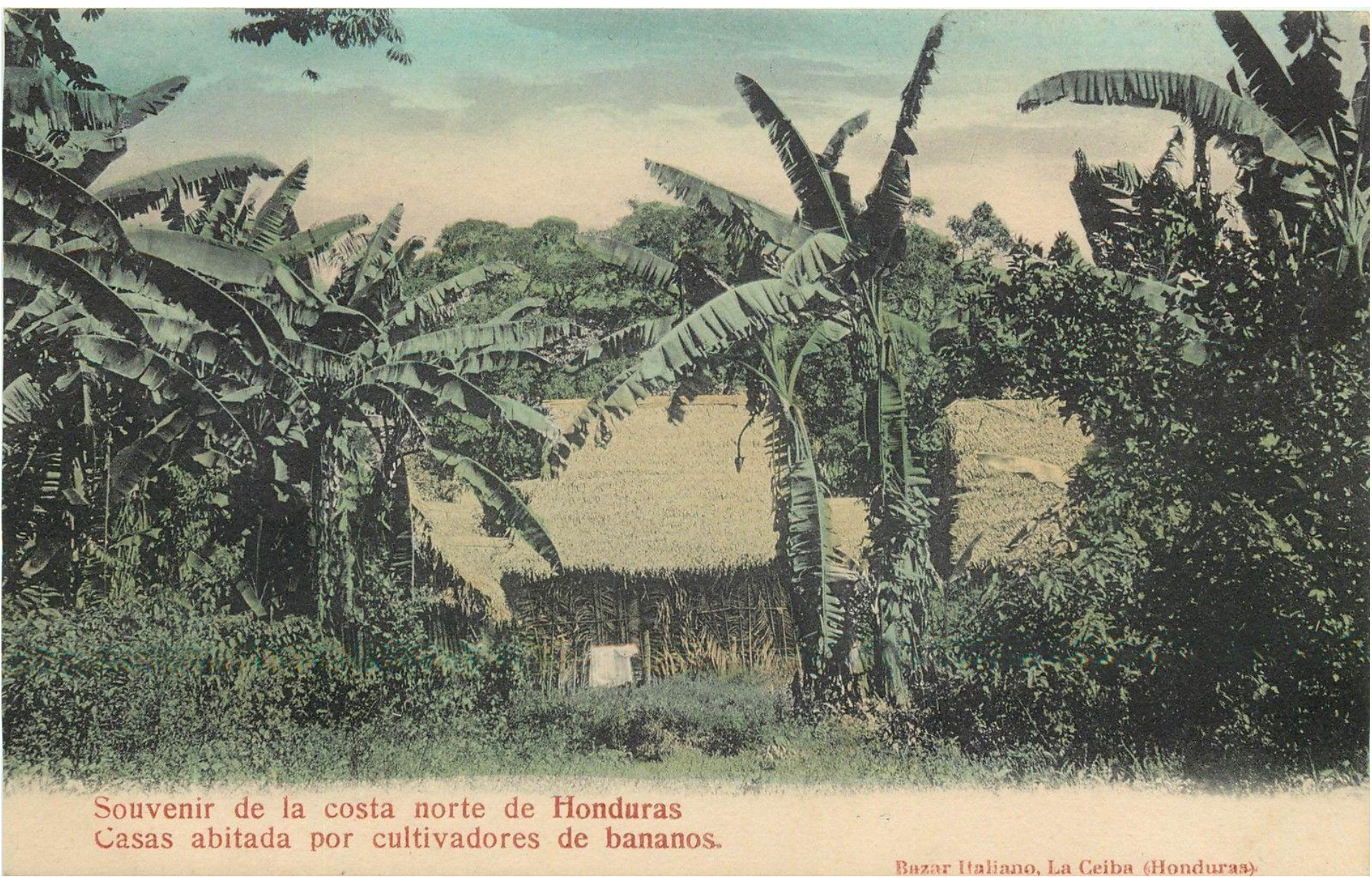

Otra postal más de la serie editada por el "Bazar Italiano" de E. Bombace \& Hno., que representa una típica finca de bananos cercana a La Ceiba, Honduras. 
Artigo original

Hegemonia - Revista Eletrônica do Programa de Mestrado em Direitos Humanos, Cidadania e Violência/Ciência Política do Centro Universitário Unieuro ISSN: $1809-1261$

UNIEURO, Brasília, número 24, Julho a Dezembro de 2018, pp. 110-259.

POSTAL 30

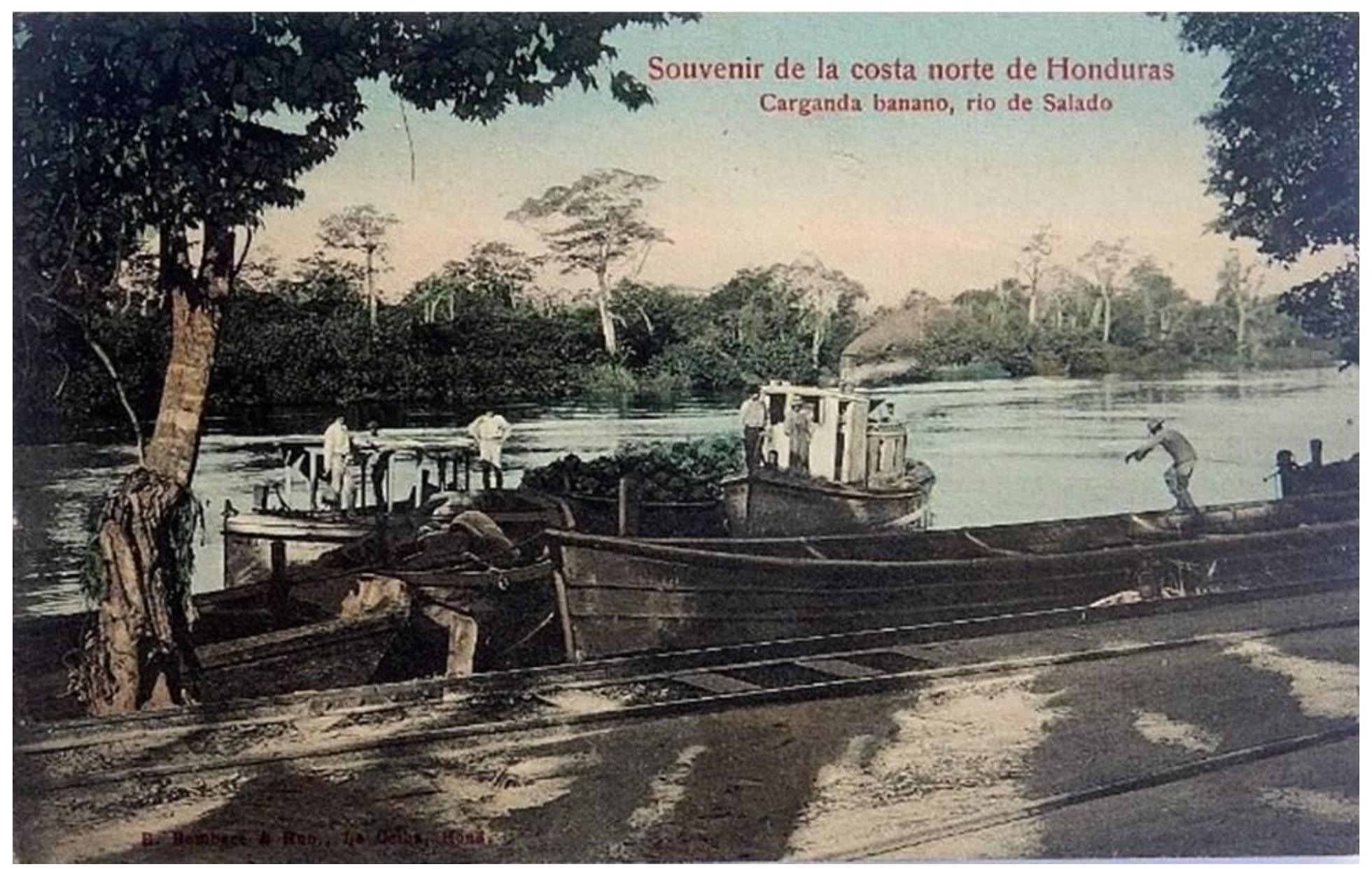

Otra postal del acarreo de bananas a través del Río Cuero y Salado, en las cercanías de La Ceiba. La vía férrea yace en la ribera del río, y los obreros cargan los racimos desde las lanchas hacia las goletas que llevarán a puerto la preciada fruta. 
Artigo original

Hegemonia - Revista Eletrônica do Programa de Mestrado em Direitos Humanos, Cidadania e Violência/Ciência Política do Centro Universitário Unieuro ISSN: $1809-1261$

UNIEURO, Brasília, número 24, Julho a Dezembro de 2018, pp. 110-259.

\section{POSTAL 31}

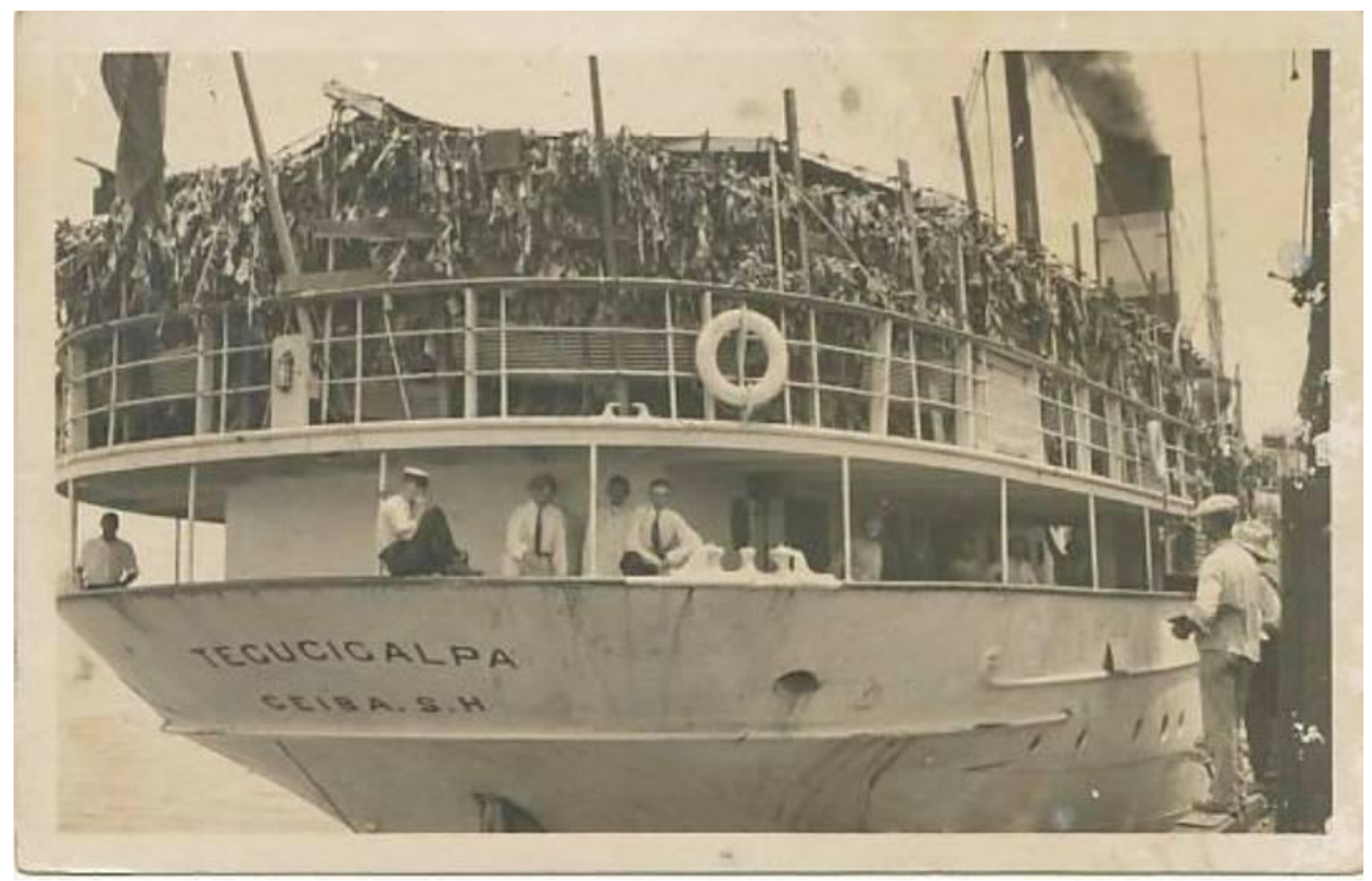

Hermosa postal de los años veinte de la "Goleta Tegucigalpa", una de las que acarreaba bananas hacia el puerto de La Ceiba. Como se ve, las compañías transnacionales pusieron a disposición todo tipo de transportes para hacer totalmente eficiente la exportación de bananos. 
Artigo original

Hegemonia - Revista Eletrônica do Programa de Mestrado em Direitos Humanos, Cidadania e Violência/Ciência Política do Centro Universitário Unieuro ISSN: $1809-1261$

UNIEURO, Brasília, número 24, Julho a Dezembro de 2018, pp. 110-259.

\section{POSTAL 32}

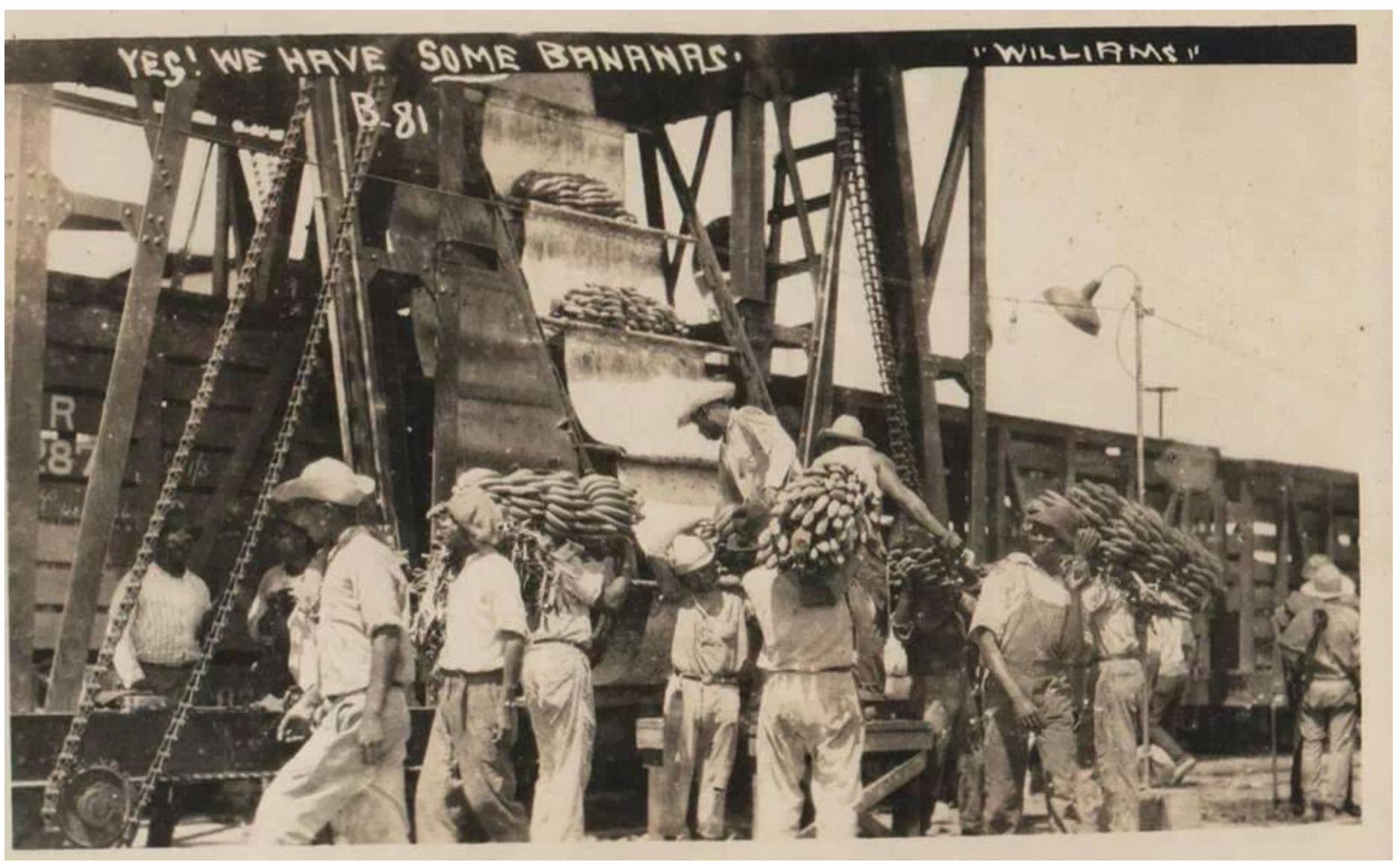

Postal de los años veinte, obra del fotógrafo Teodhore Williams, donde un grupo de obreros de las bananeras, los legendarios "muelleros", cargan bananas sobre sus espaldas para subir los racimos a los barcos de la "Gran Flota Blanca". 
Artigo original

Hegemonia - Revista Eletrônica do Programa de Mestrado em Direitos Humanos, Cidadania e Violência/Ciência Política do Centro Universitário Unieuro ISSN: 1809-1261

UNIEURO, Brasília, número 24, Julho a Dezembro de 2018, pp. 110-259.

POSTAL 33

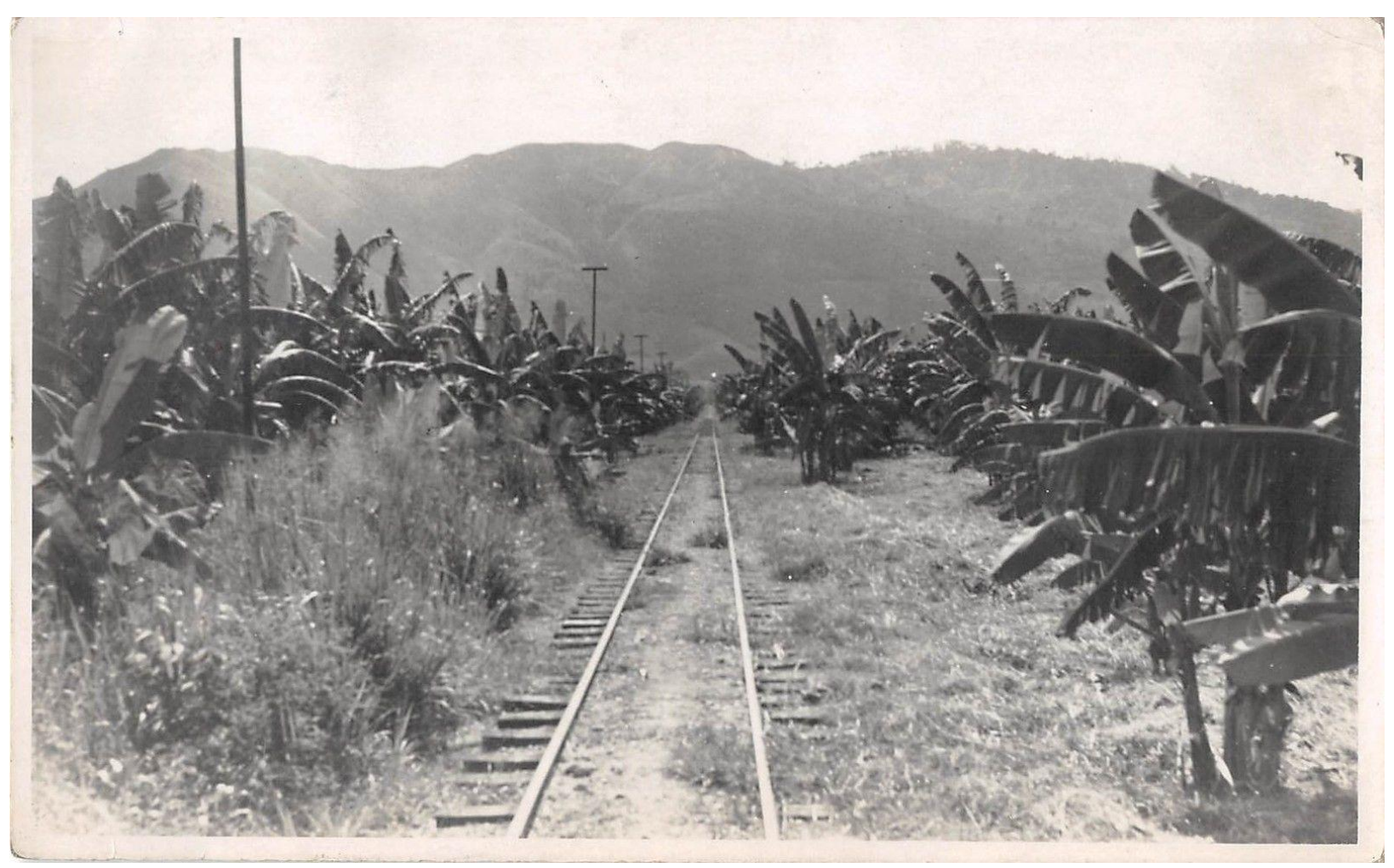

Esta postal, obra de Theodore Williams, que sencillamente ilustra una vía férrea atravesando campos de cultivo o "bananales" como se les llamaba en Honduras, tiene una potente carga simbólica: muestra cómo las compañías bananeras se imponían sobre la selva y la manigua del trópico centroamericano, era expresar la dicotomía entre "civilización y barbarie". En esa antítesis, el ferrocarril -símbolo esencial de la Revolución Industrial- pretendía mostrar el arribo de la Modernidad a estas tierras antes yermas y bárbaras. 
Artigo original

Hegemonia - Revista Eletrônica do Programa de Mestrado em Direitos Humanos, Cidadania e Violência/Ciência Política do Centro Universitário Unieuro ISSN: 1809-1261

UNIEURO, Brasília, número 24, Julho a Dezembro de 2018, pp. 110-259.

\section{POSTAL 34}

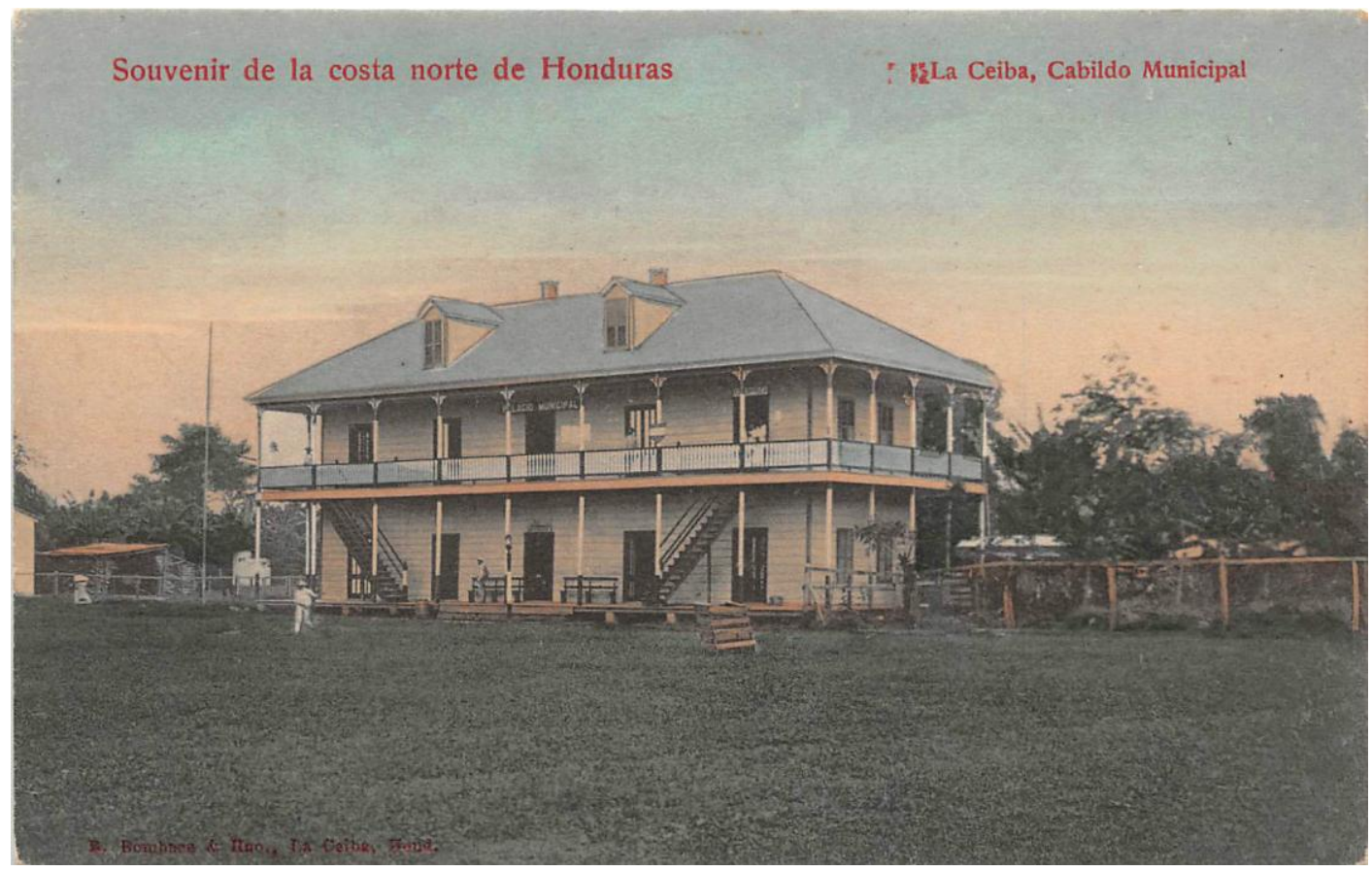

La llegada de las bananeras marcó también la trasplantación de elementos culturales norteamericanos a las regiones bananeras de Honduras, como se aprecia en esta tarjeta postal editada por "E. Bombace \& Hno", donde se aprecia el edificio del antiguo Cabildo Municipal de La Ceiba, construido en la típica arquitectura del sur de los Estados Unidos, de tipo victoriana, con materiales de madera y láminas de zinc, en contraste a la arquitectura tradicional de los pueblos del interior heredada de la Colonia, de casas de adobe o piedra y tejas. Estos nuevos edificios de los centros urbanos bananeros fueron copiados al estilo de la arquitectura de las zonas originarias de los funcionarios de las compañías fruteras, como Nueva Orléans, Mobile o Alabama. Con ello, se provocaron interesantes transformaciones culturales, como la formación de los "Company Town". 
Artigo original

Hegemonia - Revista Eletrônica do Programa de Mestrado em Direitos Humanos, Cidadania e Violência/Ciência Política do Centro Universitário Unieuro ISSN: $1809-1261$

UNIEURO, Brasília, número 24, Julho a Dezembro de 2018, pp. 110-259.

POSTAL 35

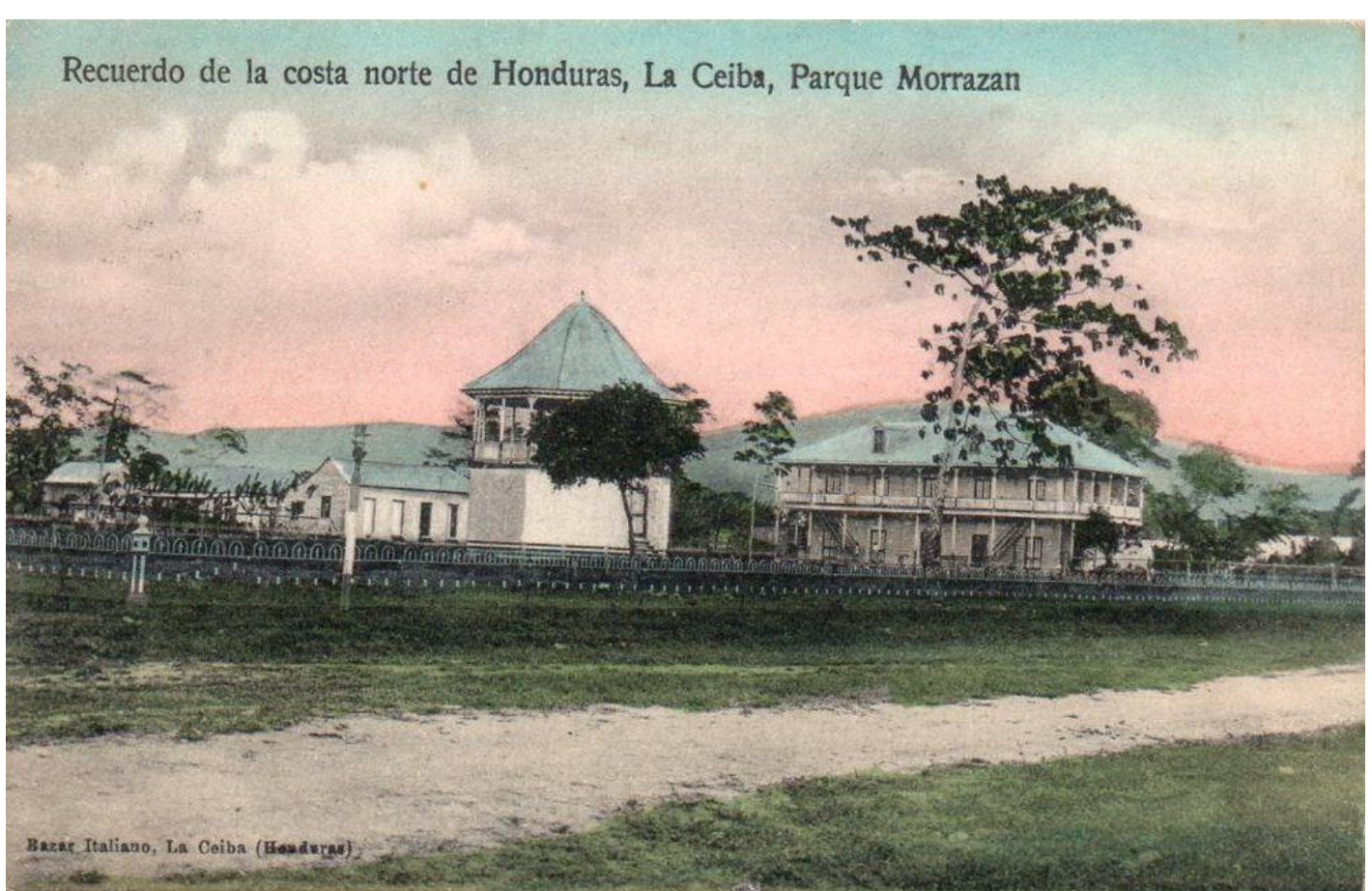

Hermosa estampa del "Parque Morazán" a principios del siglo XX de la ciudad de La Ceiba, con su quiosco y su verja de hierro, elementos estéticos copiados de los espacios públicos y parques europeos y norteamericanos de la "Belle Epoque", con lo cual se pretendía dar un "toque de modernidad" a los espacios públicos de los centros bananeros para transmitir la idea de "Modernidad". 


\section{Artigo original}

Hegemonia - Revista Eletrônica do Programa de Mestrado em Direitos Humanos, Cidadania e Violência/Ciência Política do Centro Universitário Unieuro ISSN: 1809-1261

UNIEURO, Brasília, número 24, Julho a Dezembro de 2018, pp. 110-259.

\section{POSTAL 36}

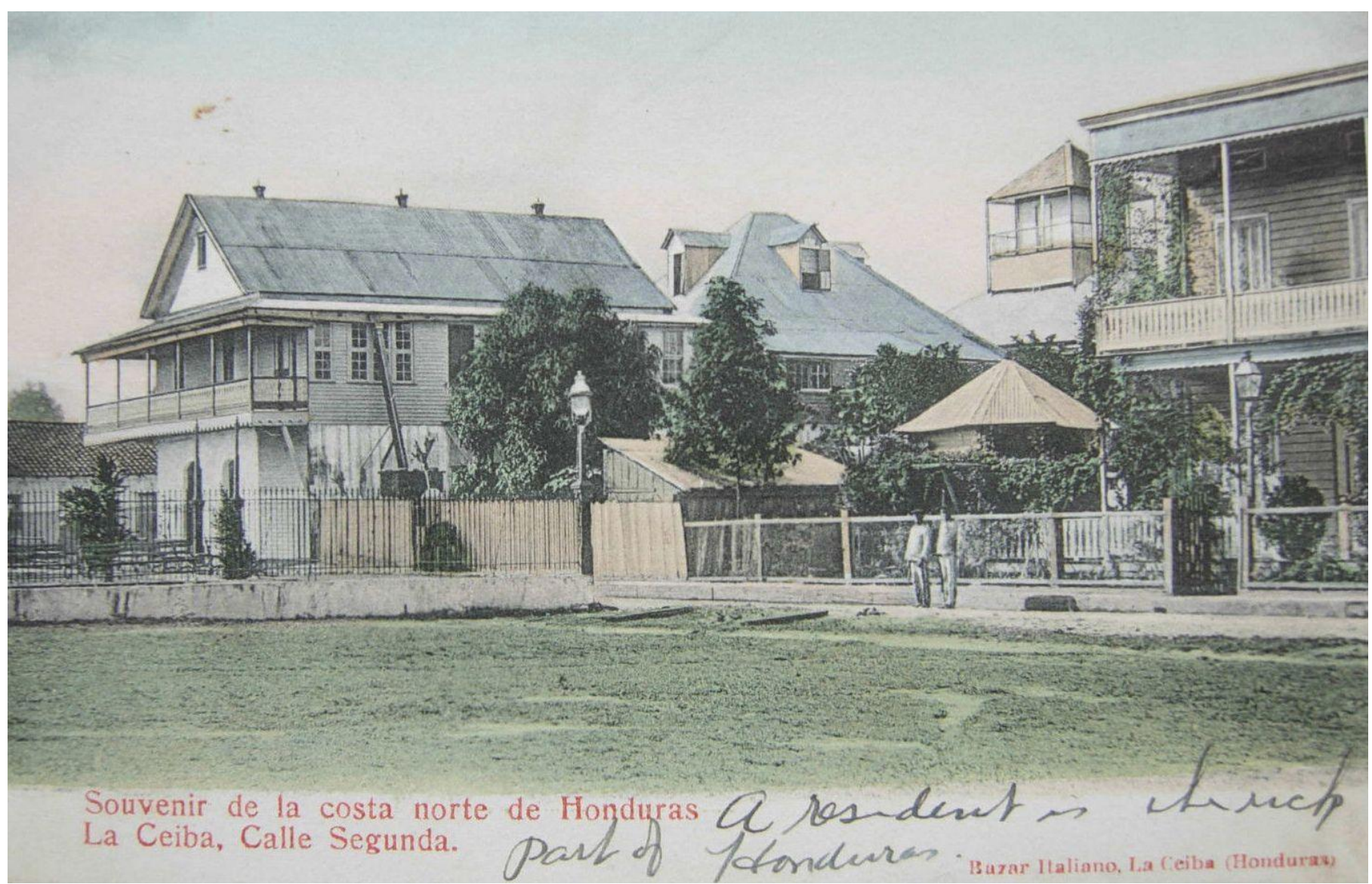

Otra espectacular tarjeta postal de los años veinte editada por el "Bazar Italiano" de un conjunto de casas en una avenida de La Ceiba, en cuya acera posan dos guardias o serenos; el estilo arquitectónico delata inmediatamente la influencia de la arquitectura de estilo victoriano que se impuso en los "Company Town". 
Artigo original

Hegemonia - Revista Eletrônica do Programa de Mestrado em Direitos Humanos, Cidadania e Violência/Ciência Política do Centro Universitário Unieuro ISSN: $1809-1261$

UNIEURO, Brasília, número 24, Julho a Dezembro de 2018, pp. 110-259.

\section{POSTAL 37}

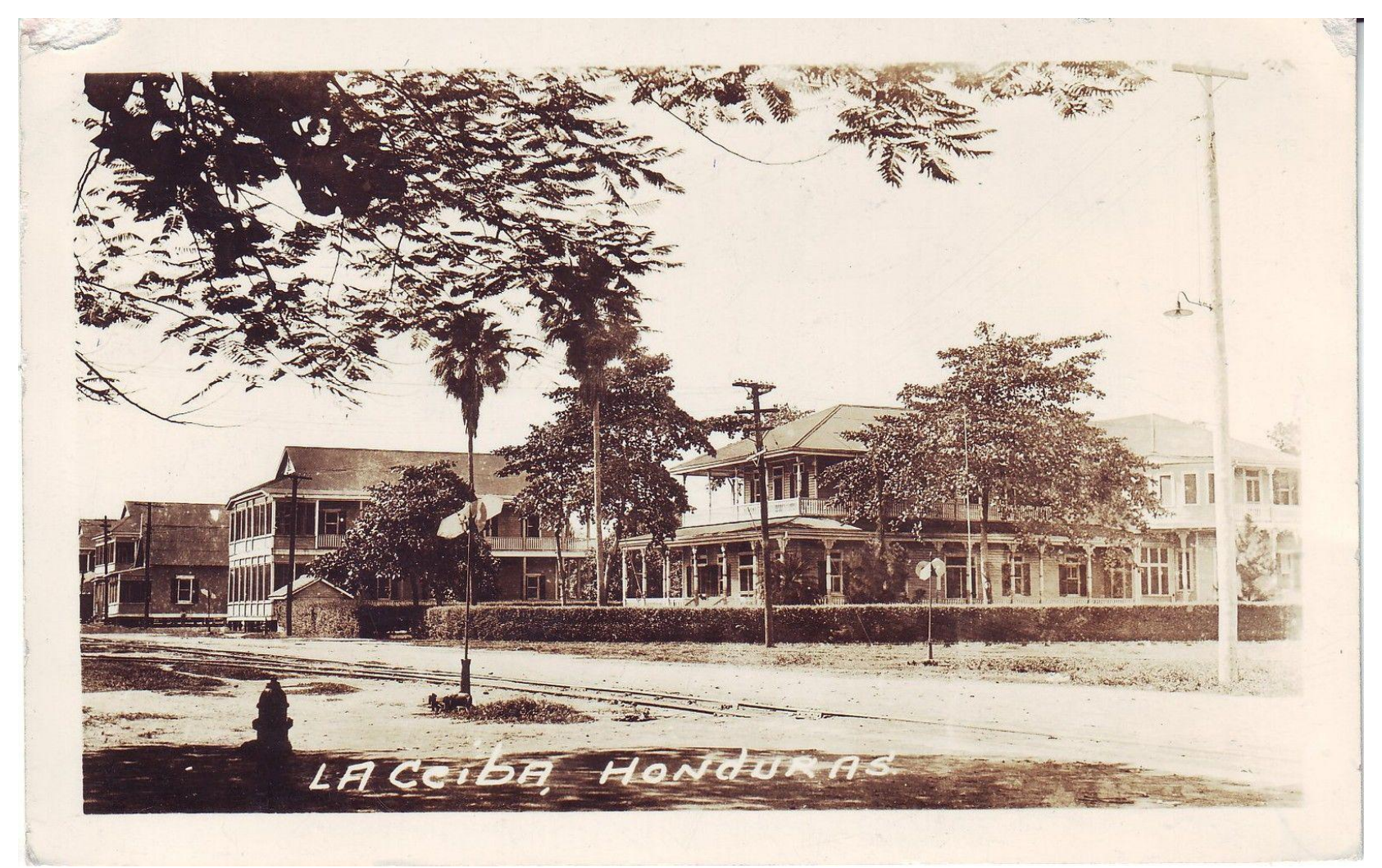

Postal de la década de los treinta, que ilustra una avenida de la ciudad puerto de La Ceiba, con hermosas casas y mansiones de madera y techos de zinc, que resalta de nuevo la idea de la trasplantación de la arquitectura del sur de los Estados Unidos a la costa norte de Honduras. 
Artigo original

Hegemonia - Revista Eletrônica do Programa de Mestrado em Direitos Humanos, Cidadania e Violência/Ciência Política do Centro Universitário Unieuro ISSN: 1809-1261

UNIEURO, Brasília, número 24, Julho a Dezembro de 2018, pp. 110-259.

POSTAL 38

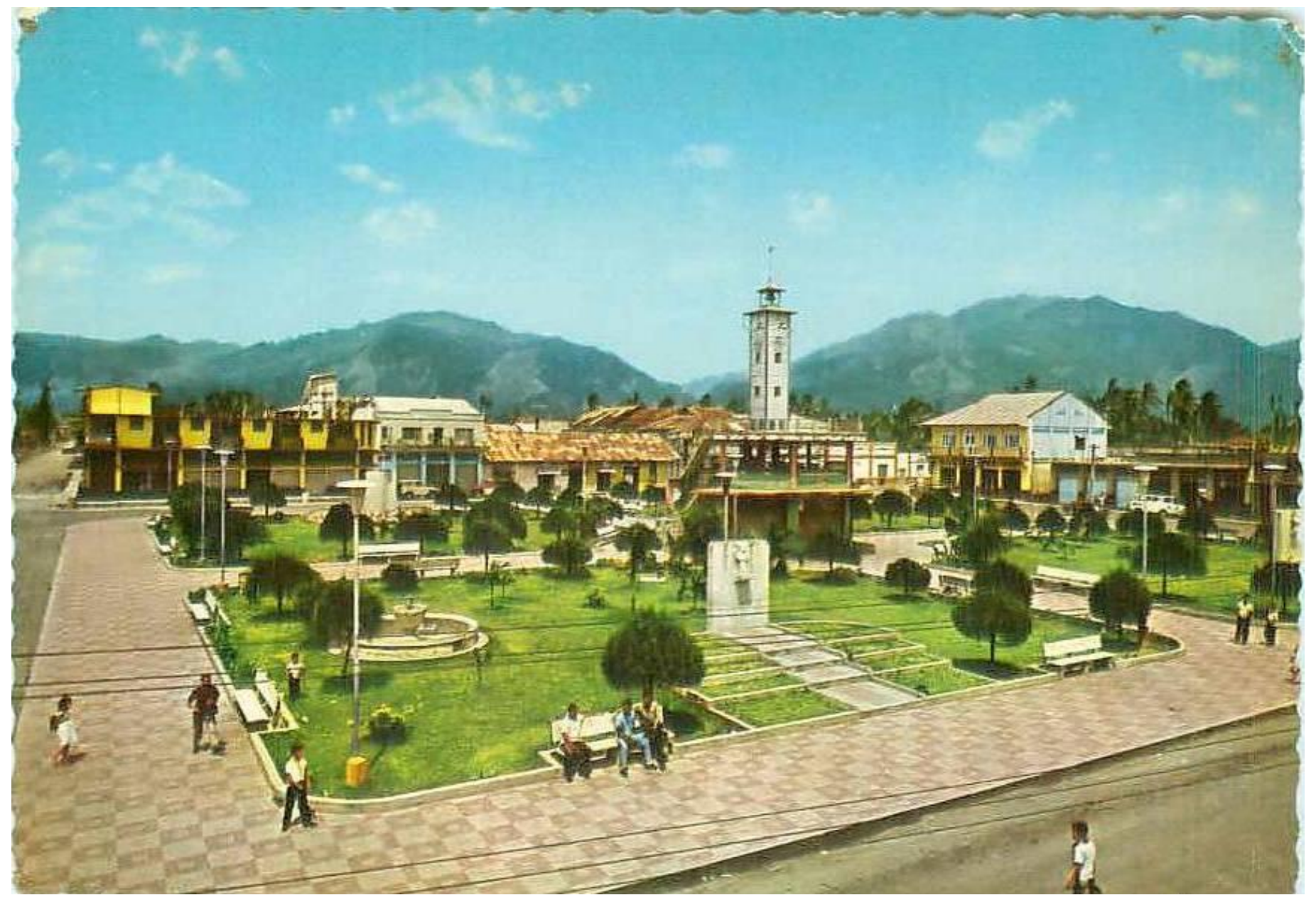

Parque central de la ciudad de El Progreso, en el departamento de Yoro, en esta hermosa postal de los años sesenta, que recrea la influencia de la arquitectura estadounidense especialmente en la Iglesia de madera. 
Artigo original

Hegemonia - Revista Eletrônica do Programa de Mestrado em Direitos Humanos, Cidadania e Violência/Ciência Política do Centro Universitário Unieuro ISSN: $1809-1261$

UNIEURO, Brasília, número 24, Julho a Dezembro de 2018, pp. 110-259.

POSTAL 39

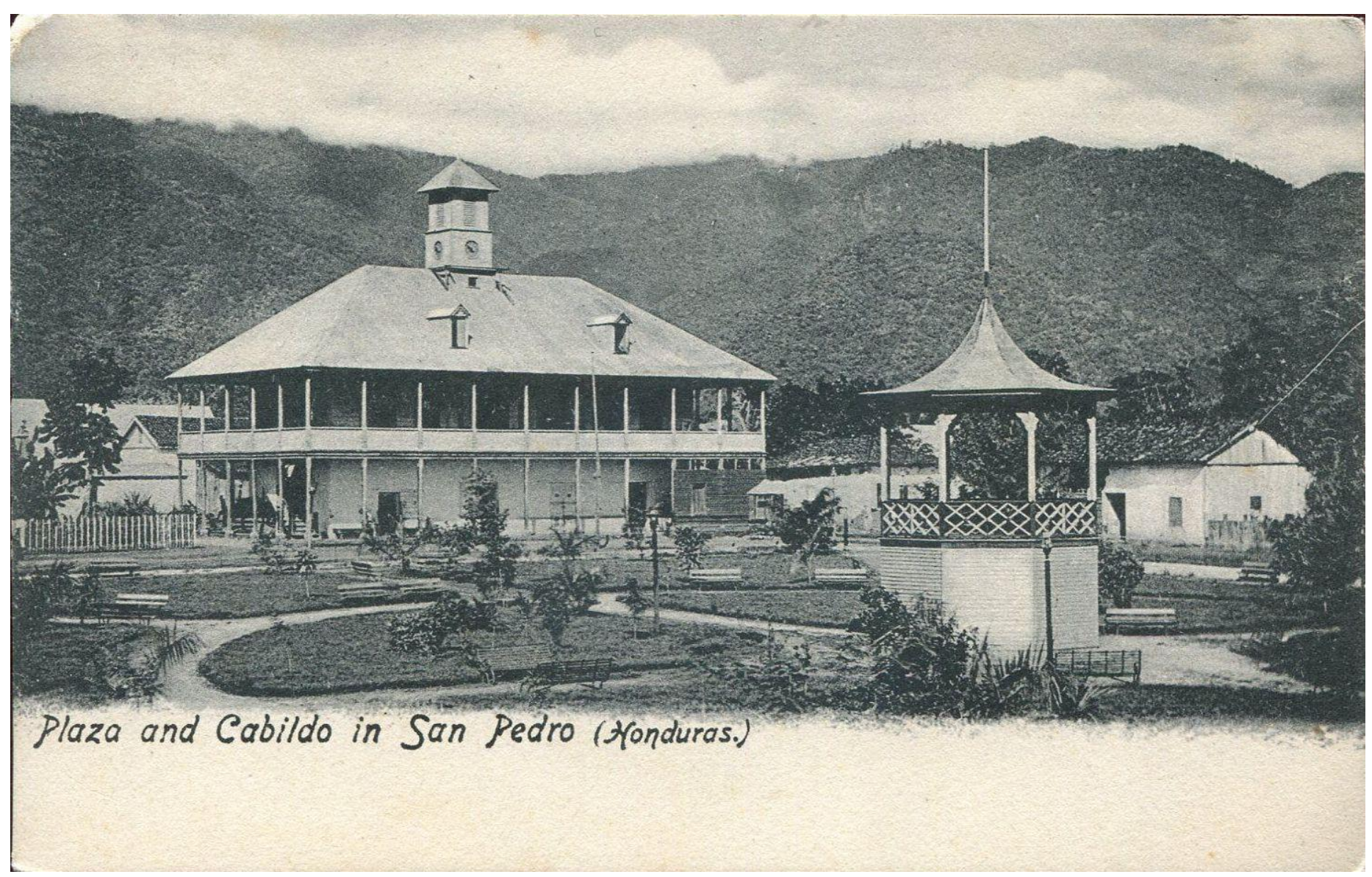

Hermosa postal de la plaza y el cabildo de San Pedro Sula, en esta hermosa postal de 1908 obra del norteamericano J. A. Doubleday. En ella se reflejan las tendencias de la influencia de la arquitectura norteamericana, sobre todo en el diseño del edificio del antiguo cabildo (sin duda importado de EEUU), así como en la estructura de la plaza, con tendencia a la moda de los parques ajardinados y el quiosco de estilo francés. 
Artigo original

Hegemonia - Revista Eletrônica do Programa de Mestrado em Direitos Humanos, Cidadania e Violência/Ciência Política do Centro Universitário Unieuro ISSN: $1809-1261$

UNIEURO, Brasília, número 24, Julho a Dezembro de 2018, pp. 110-259.

POSTAL 40

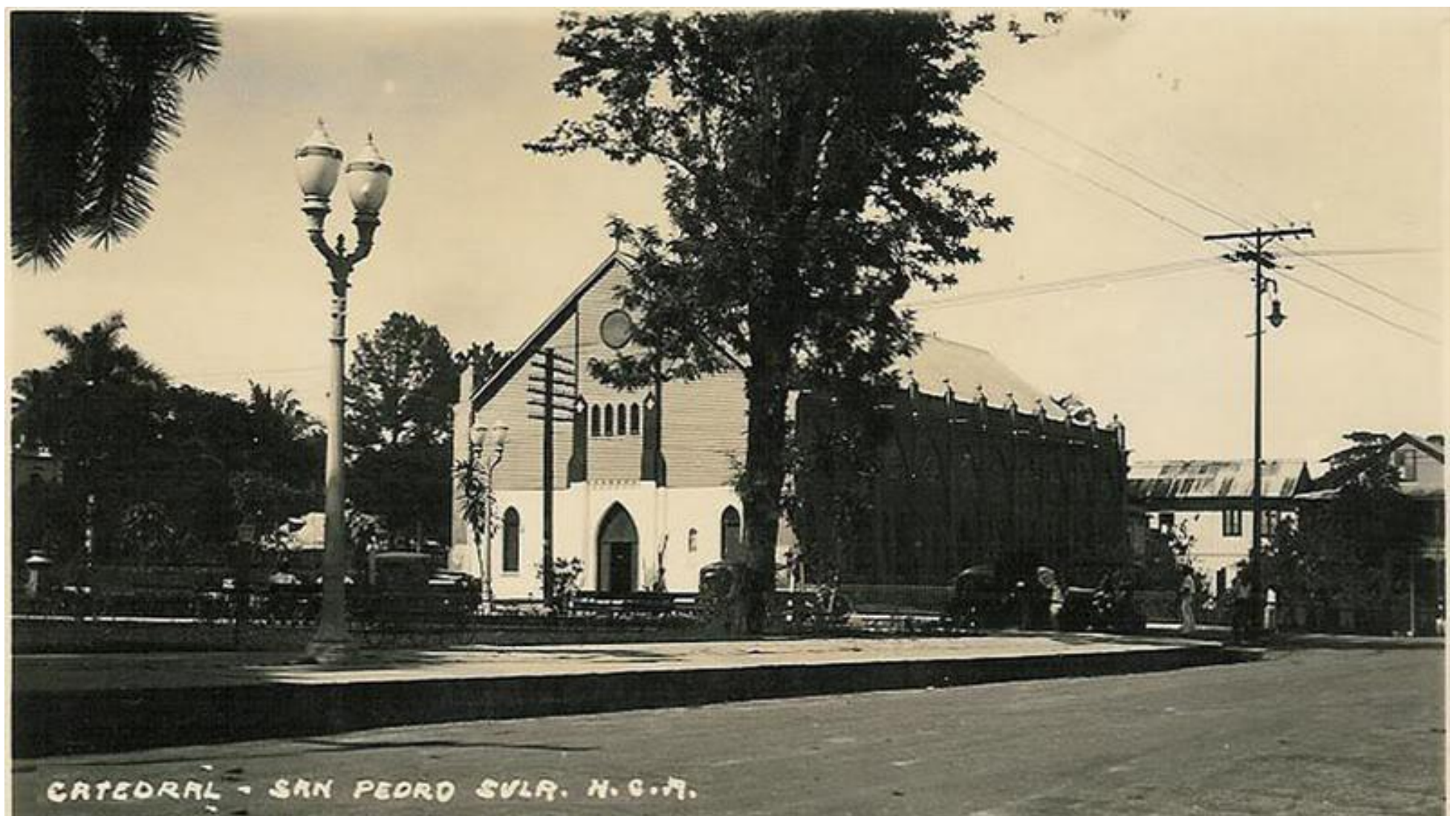

Extraordinaria y elegante tarjeta postal de la antigua Catedral de San Pedro Sula, que muestra la influencia de las iglesias neogóticas estadounidenses, especialmente reflejadas en el pórtico y en los ventanales laterales, rematados en arcos ojivales. Dicha iglesia, que fue la segunda que tuvo la ciudad, fue demolida y en su lugar se construyó la actual catedral monumental que ostenta con orgullo la "Ciudad de los Zorzales". 
Artigo original

Hegemonia - Revista Eletrônica do Programa de Mestrado em Direitos Humanos, Cidadania e Violência/Ciência Política do Centro Universitário Unieuro ISSN: 1809-1261

UNIEURO, Brasília, número 24, Julho a Dezembro de 2018, pp. 110-259.

Postal 41

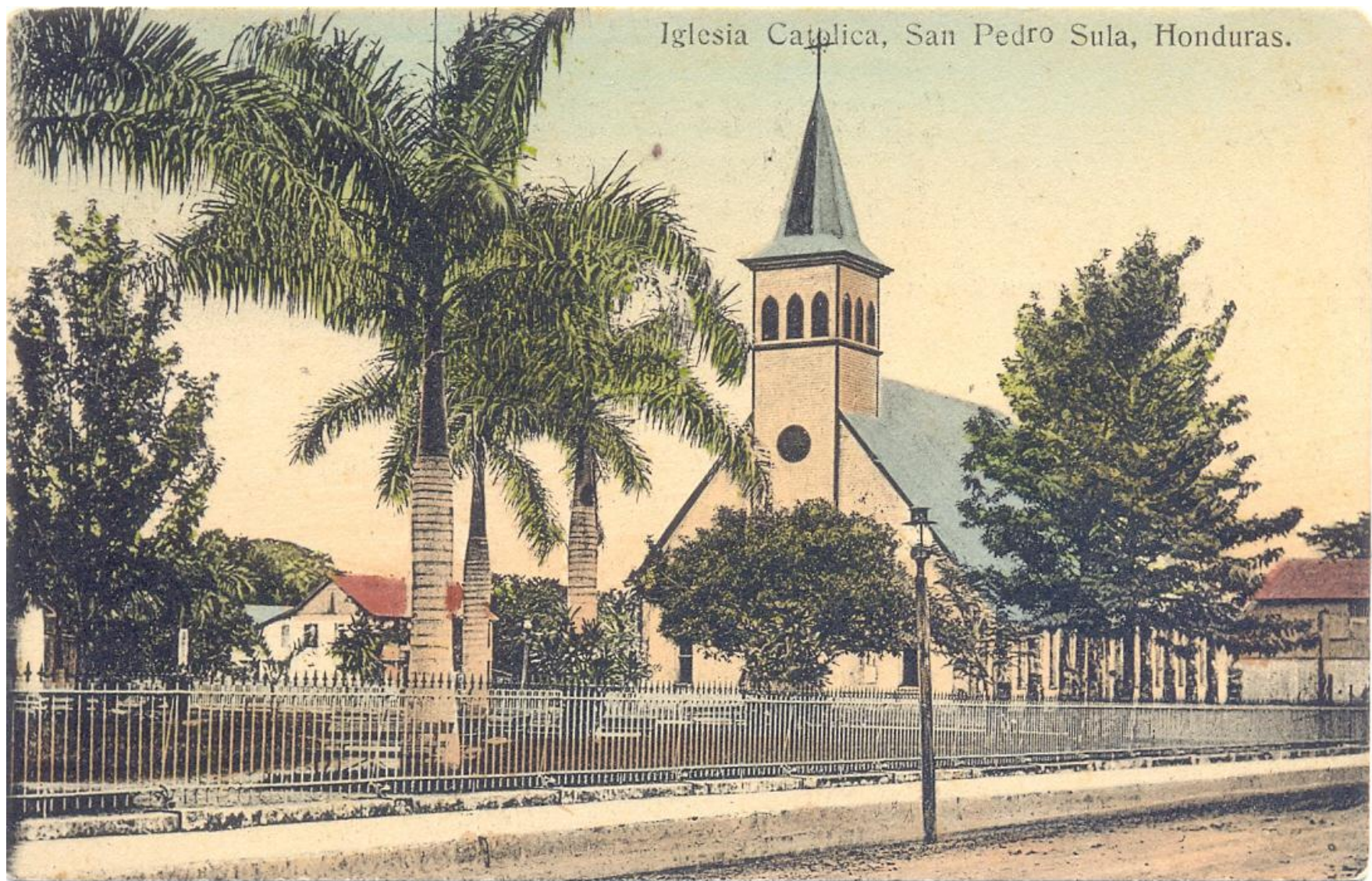

Bellísima postal coloreada de la década de 1910 de la “catedral de San Pedro Sula”, y en primer plano, la elegante verja de hierro importada de Inglaterra. 
Artigo original

Hegemonia - Revista Eletrônica do Programa de Mestrado em Direitos Humanos, Cidadania e Violência/Ciência Política do Centro Universitário Unieuro ISSN: 1809-1261

UNIEURO, Brasília, número 24, Julho a Dezembro de 2018, pp. 110-259.

POSTAL 42

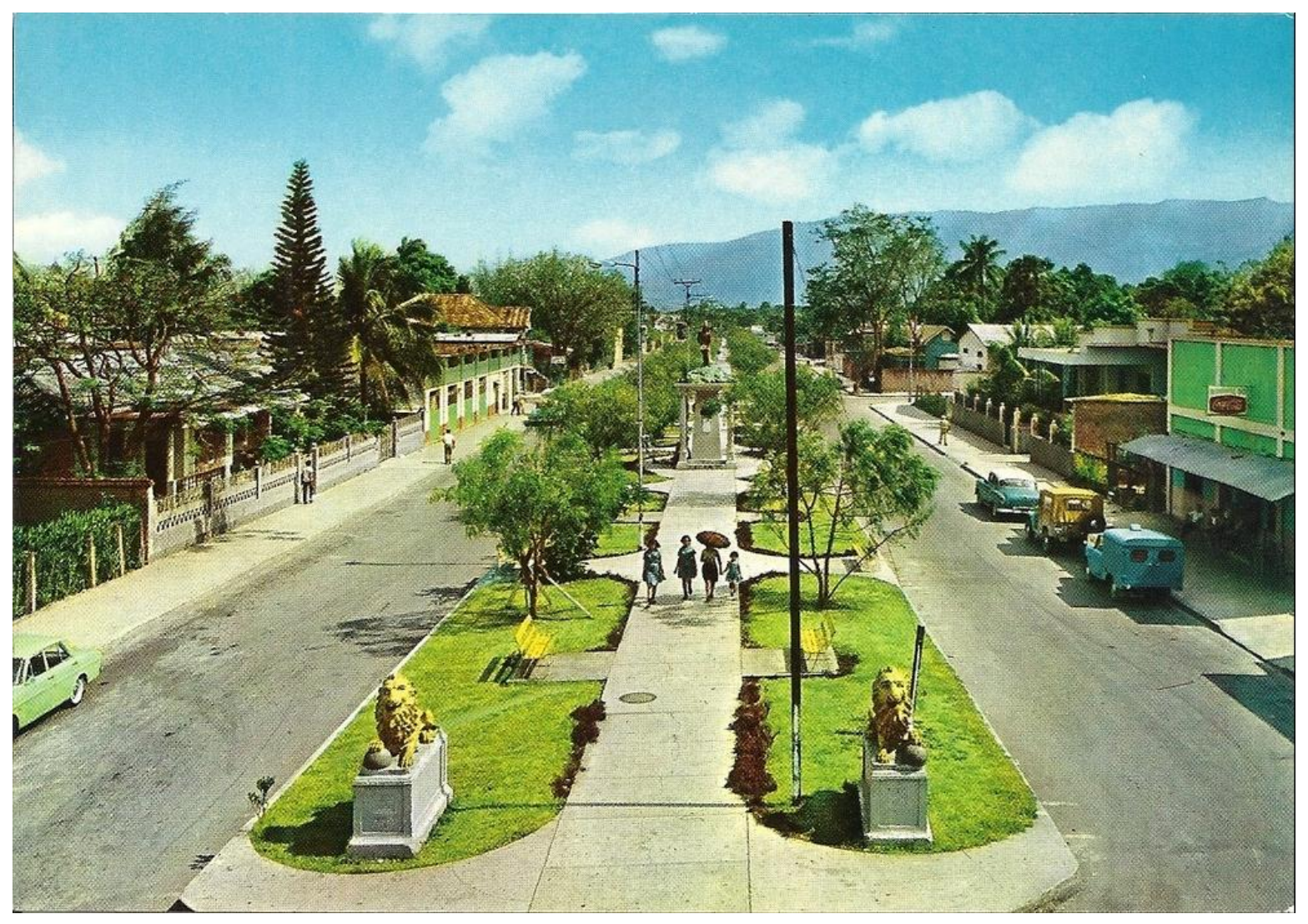

Esta es una de las tarjetas postales más hermosas de los territorios de influencia bananera. Es una estampa de la famosa "Avenida de Los Leones" o "Avenida Lempira" de San Pedro Sula, que nos recrea el ordenado bulevar como lugar de paseo, y en el centro la estatua del legendario héroe Lempira, donada por la colonia palestina en 1936 con motivo del cuarto centenario de fundación de la ciudad. El entorno urbano nos recuerda los elegantes paseos de ciudades del sur de los Estados Unidos, como Nueva Orléans. 
Artigo original

Hegemonia - Revista Eletrônica do Programa de Mestrado em Direitos Humanos, Cidadania e Violência/Ciência Política do Centro Universitário Unieuro ISSN: $1809-1261$

UNIEURO, Brasília, número 24, Julho a Dezembro de 2018, pp. 110-259.

\section{POSTAL 43}

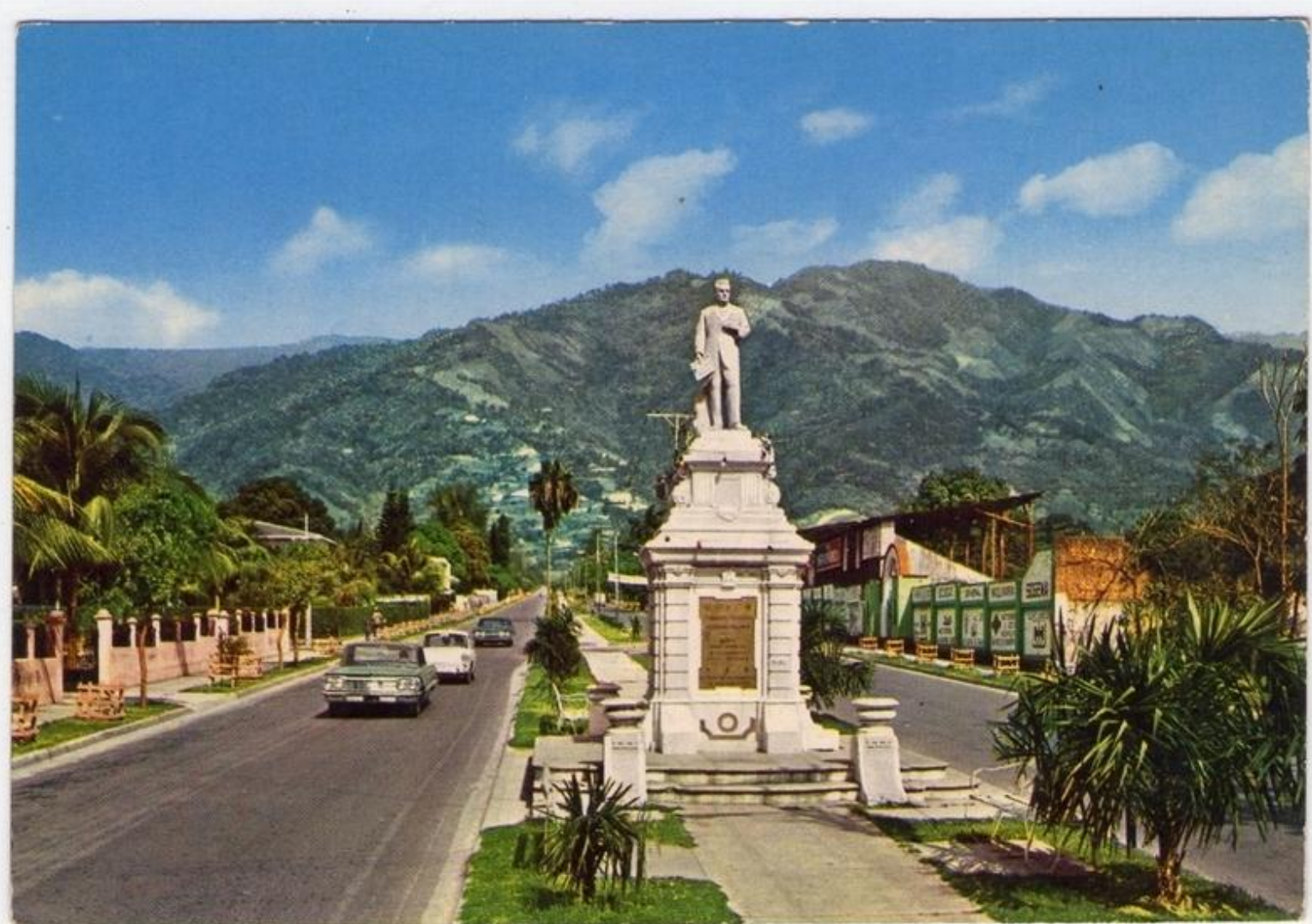

Otra bellísima postal de los años sesenta de la primera calle de San Pedro Sula, o "Bulevar Morazán", que ilustra en primer plano la elegante estatua de Francisco Morazán erigida en 1921 con motivo del "Primer centenario de la Independencia", y al fondo, la sierra del Merendón un tanto deforestada. Estos nuevos bulevares y espacios públicos daban cuenta de la progresiva modernización urbana de las ciudades de la costa norte de Honduras a partir de la llegada de las compañías fruteras. 
Artigo original

Hegemonia - Revista Eletrônica do Programa de Mestrado em Direitos Humanos, Cidadania e Violência/Ciência Política do Centro Universitário Unieuro ISSN: 1809-1261

UNIEURO, Brasília, número 24, Julho a Dezembro de 2018, pp. 110-259.

\section{POSTAL 44}

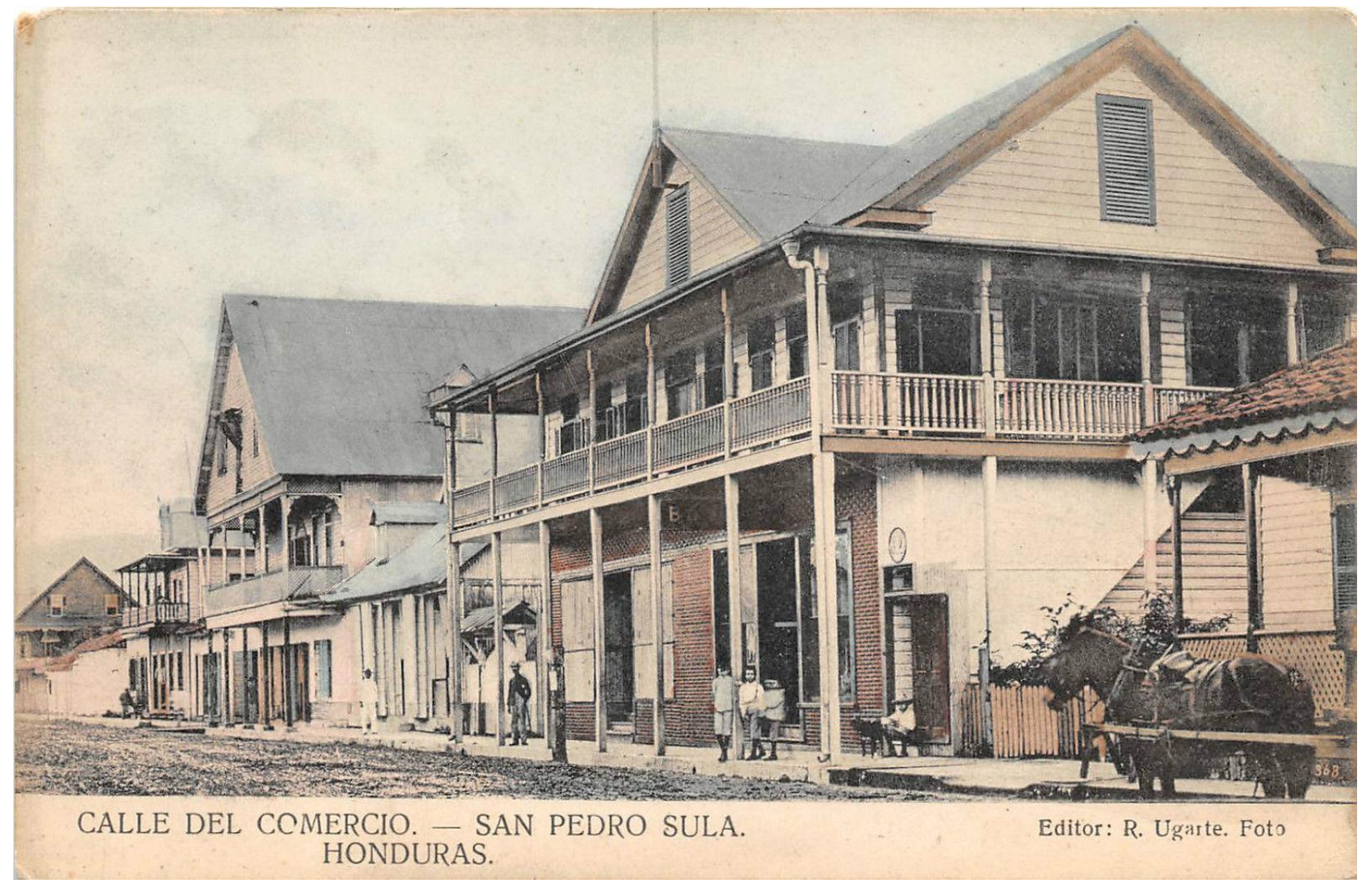

Una atractiva postal de la Calle del Comercio de San Pedro Sula, de la primera década del siglo XX, editada por don Rafael Ugarte, donde se aprecia en detalle las casas de estilo arquitectónico estadounidense, construidas de madera y techos de zinc, con corredores y terrazas para paliar el calor tropical, parecidas a las que se ven en las "películas de vaqueros". 
Artigo original

Hegemonia - Revista Eletrônica do Programa de Mestrado em Direitos Humanos, Cidadania e Violência/Ciência Política do Centro Universitário Unieuro ISSN: $1809-1261$

UNIEURO, Brasília, número 24, Julho a Dezembro de 2018, pp. 110-259.

POSTAL 45

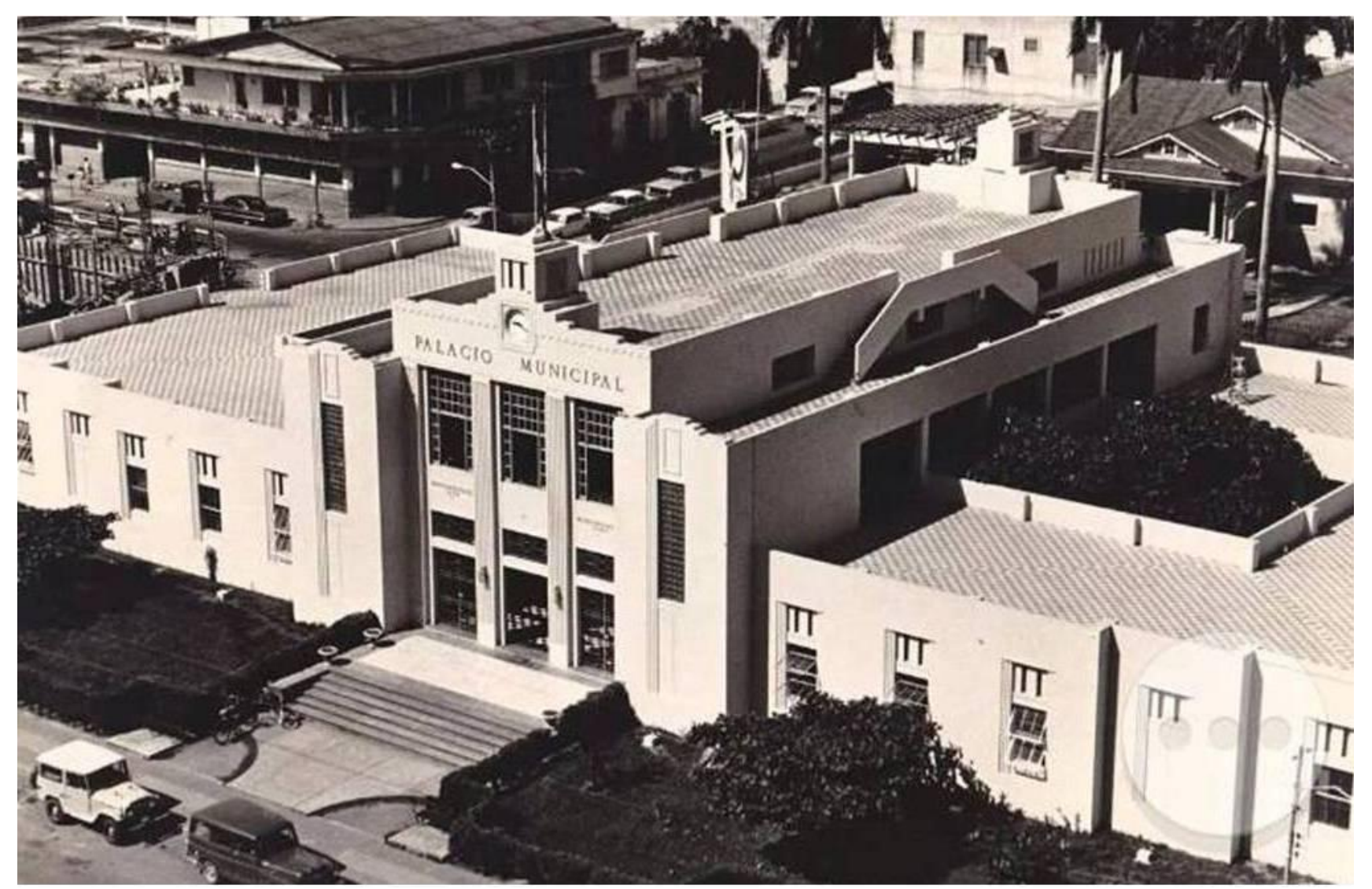

Elegante tarjeta postal aérea de los años sesenta, del "Palacio Municipal” de San Pedro Sula, de estilo Art Deco, construido en los años cuarenta, que denota la influencia de ese estilo arquitectónico especialmente desarrollado en el sur de los Estados Unidos, sobre todo en la ciudad de Miami. 
Artigo original

Hegemonia - Revista Eletrônica do Programa de Mestrado em Direitos Humanos, Cidadania e Violência/Ciência Política do Centro Universitário Unieuro ISSN: $1809-1261$

UNIEURO, Brasília, número 24, Julho a Dezembro de 2018, pp. 110-259.

POSTAL 46

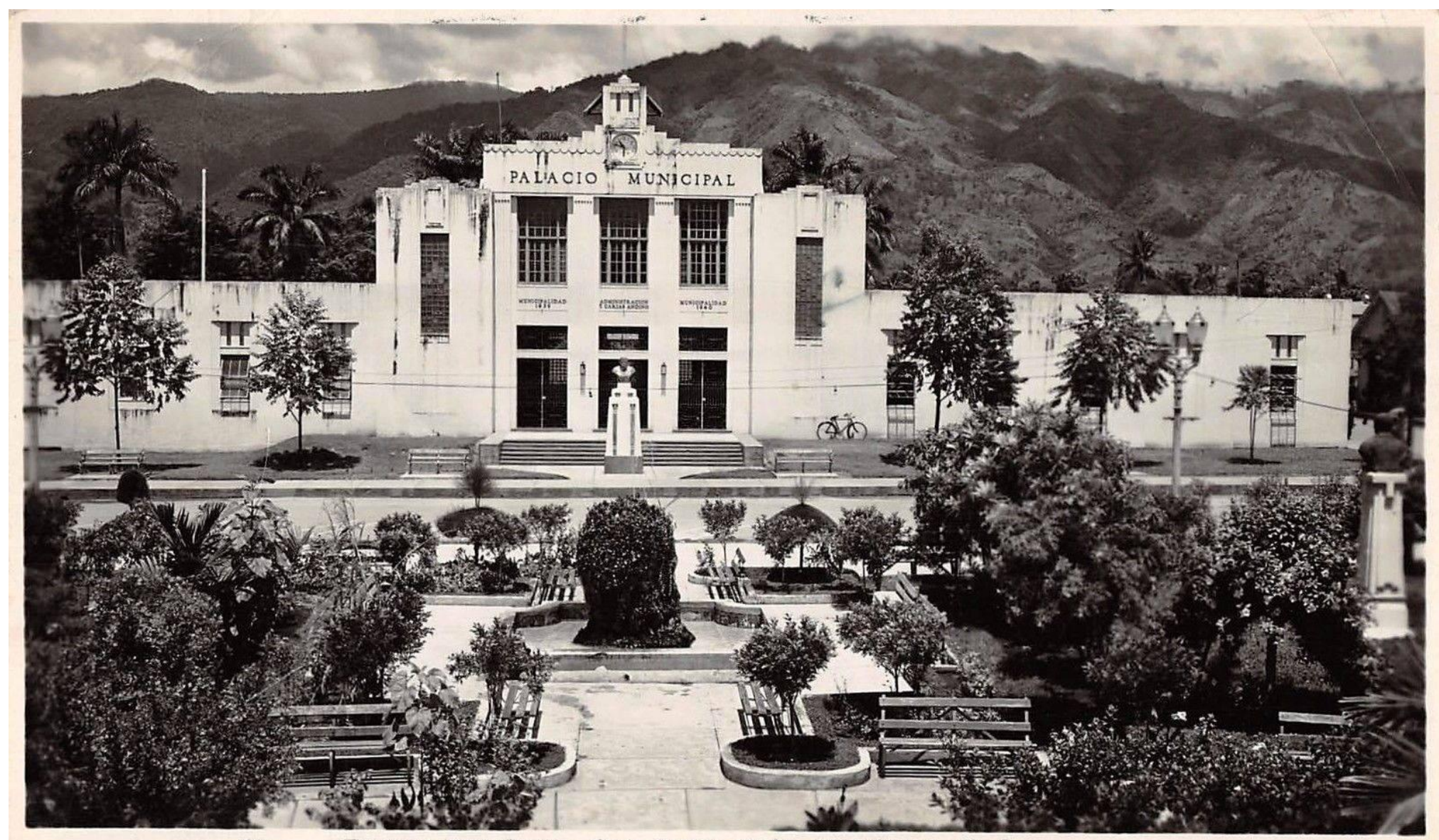

13

Parque Barahona, San Pedro Sula, Honduras, C. A.

Otra postal de 1950 del "Palacio Municipal" de San Pedro Sula, y en primer plano el "Parque Barahona" o "Parque Central", que nos ilustra la llegada de la arquitectura estilo "Art Deco" a la costa norte de Honduras. 
Artigo original

Hegemonia - Revista Eletrônica do Programa de Mestrado em Direitos Humanos, Cidadania e Violência/Ciência Política do Centro Universitário Unieuro ISSN: $1809-1261$

UNIEURO, Brasília, número 24, Julho a Dezembro de 2018, pp. 110-259.

POSTAL 47

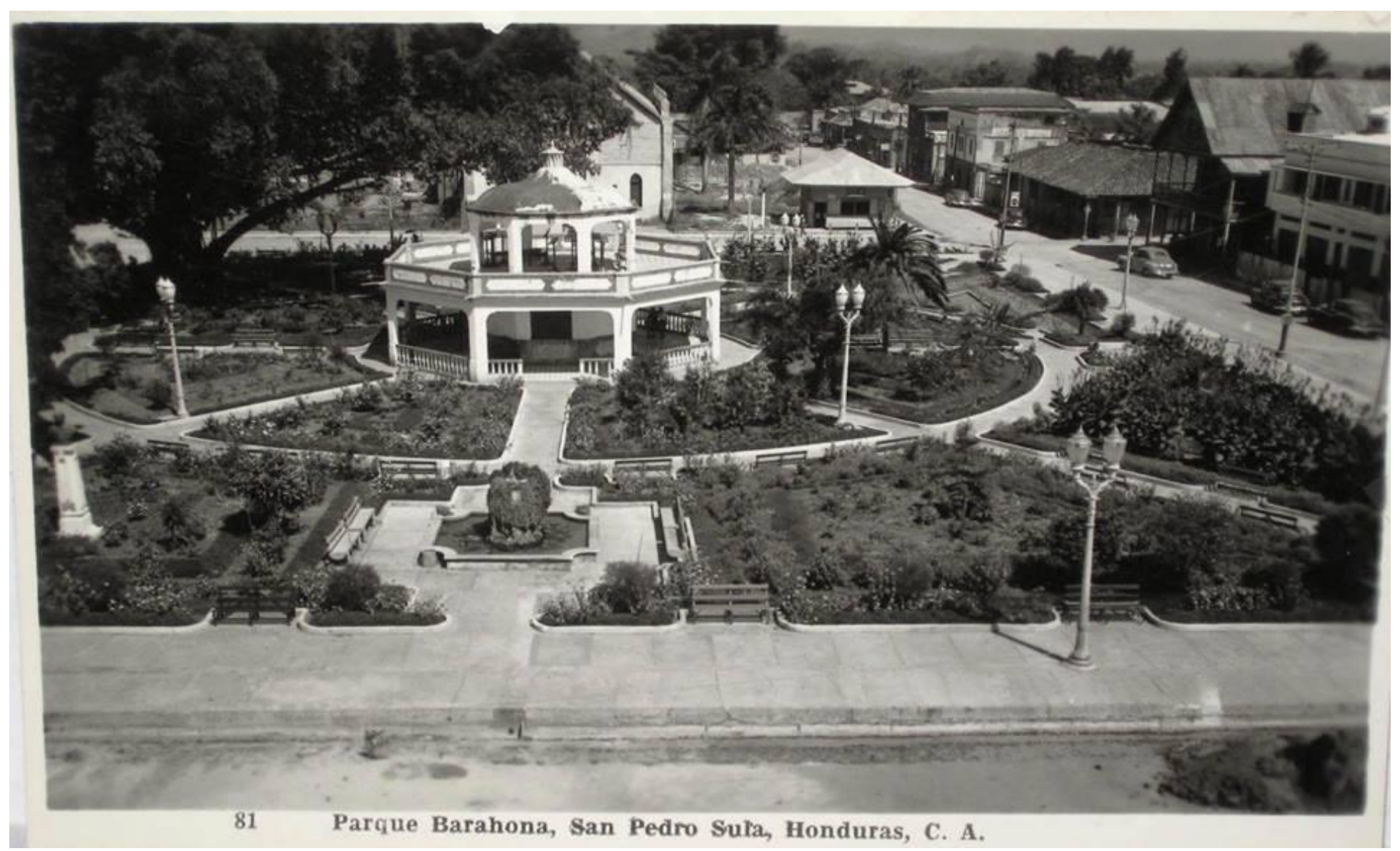

Otro plano del "Parque Barahona" y del elegante quiosco en 1950, que nos refleja el orden y ornato que se imponía en estas ciudades que pretendían emular a la ciudades norteamericanas de la cuales llegaba el capital y las modas. 
Artigo original

Hegemonia - Revista Eletrônica do Programa de Mestrado em Direitos Humanos, Cidadania e Violência/Ciência Política do Centro Universitário Unieuro ISSN: $1809-1261$

UNIEURO, Brasília, número 24, Julho a Dezembro de 2018, pp. 110-259.

\section{POSTAL 48}

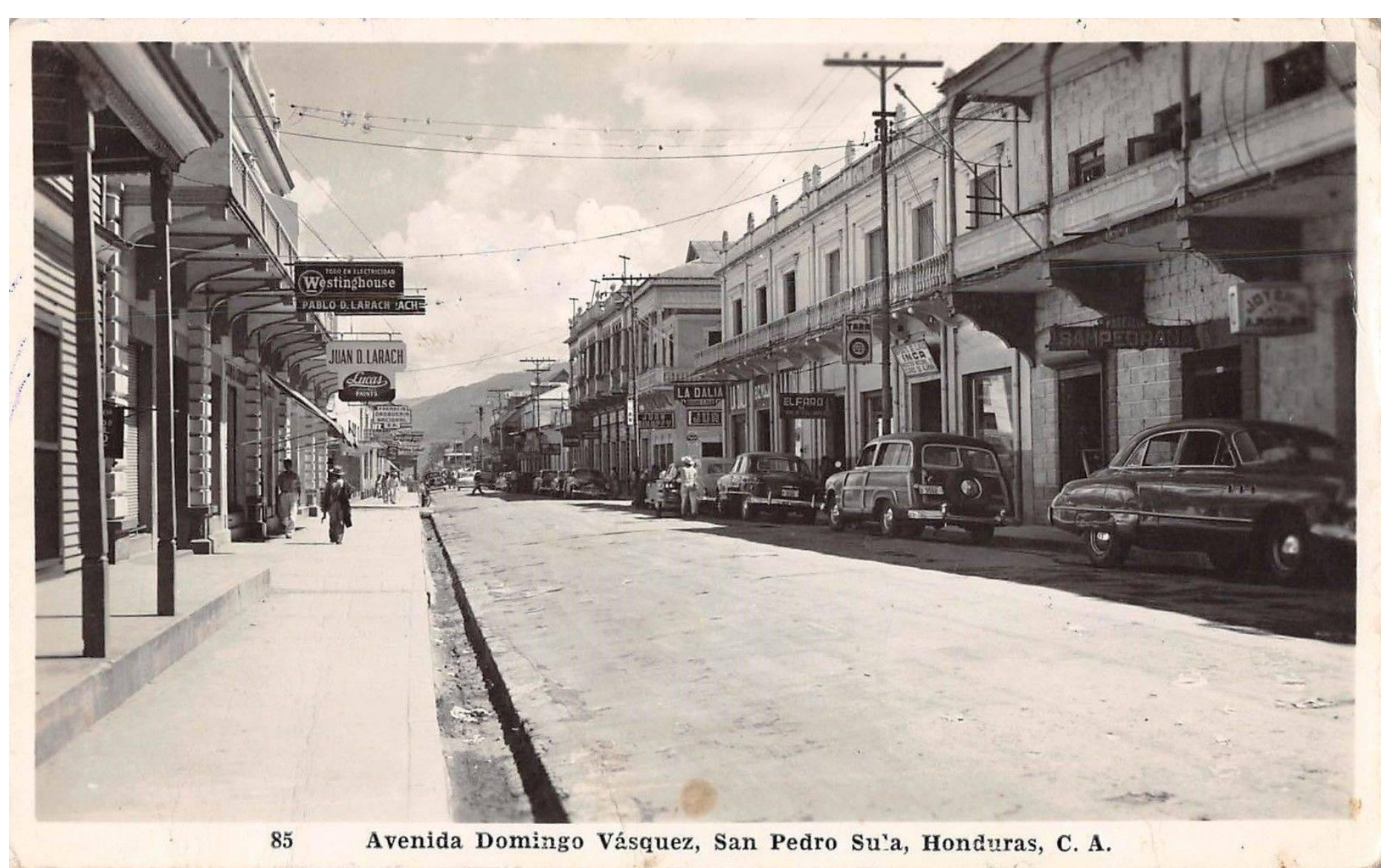

Estampa de la "Avenida Domingo Vásquez" de San Pedro Sula de la década de los sesenta, donde se aprecia el pujante comercio en las múltiples tiendas y comercios de la zona. 
Artigo original

Hegemonia - Revista Eletrônica do Programa de Mestrado em Direitos Humanos, Cidadania e Violência/Ciência Política do Centro Universitário Unieuro ISSN: $1809-1261$

UNIEURO, Brasília, número 24, Julho a Dezembro de 2018, pp. 110-259.

POSTAL 49

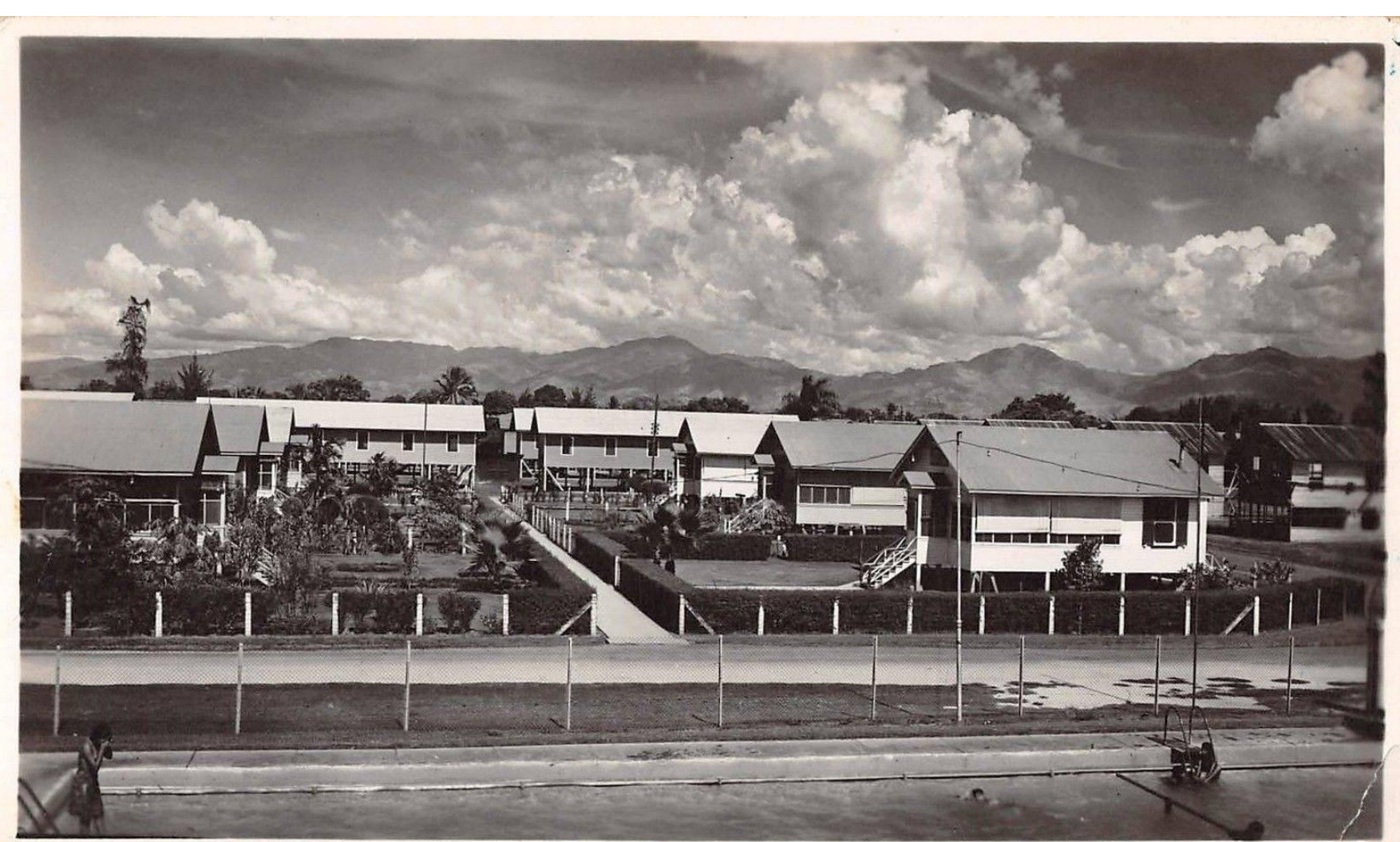

9

Vista Farcial de la Lima, Fonduras, C. A.

Esta postal es sumamente sugestiva: nos ilustra en primer plano un conjunto de casas de la Lima, Cortés, uno de los asientos importantes de la "United Fruit Company" en las cercanías de San Pedro Sula. Las casas de madera y construidas sobre polines, debido a las inundaciones, pertenecían a los funcionarios hondureños intermedios, por tanto, gozaban de mayores comodidades que las casas más modestas de los "campeños", conocidas como "barracones". 
Artigo original

Hegemonia - Revista Eletrônica do Programa de Mestrado em Direitos Humanos, Cidadania e Violência/Ciência Política do Centro Universitário Unieuro ISSN: $1809-1261$

UNIEURO, Brasília, número 24, Julho a Dezembro de 2018, pp. 110-259.

POSTAL 50

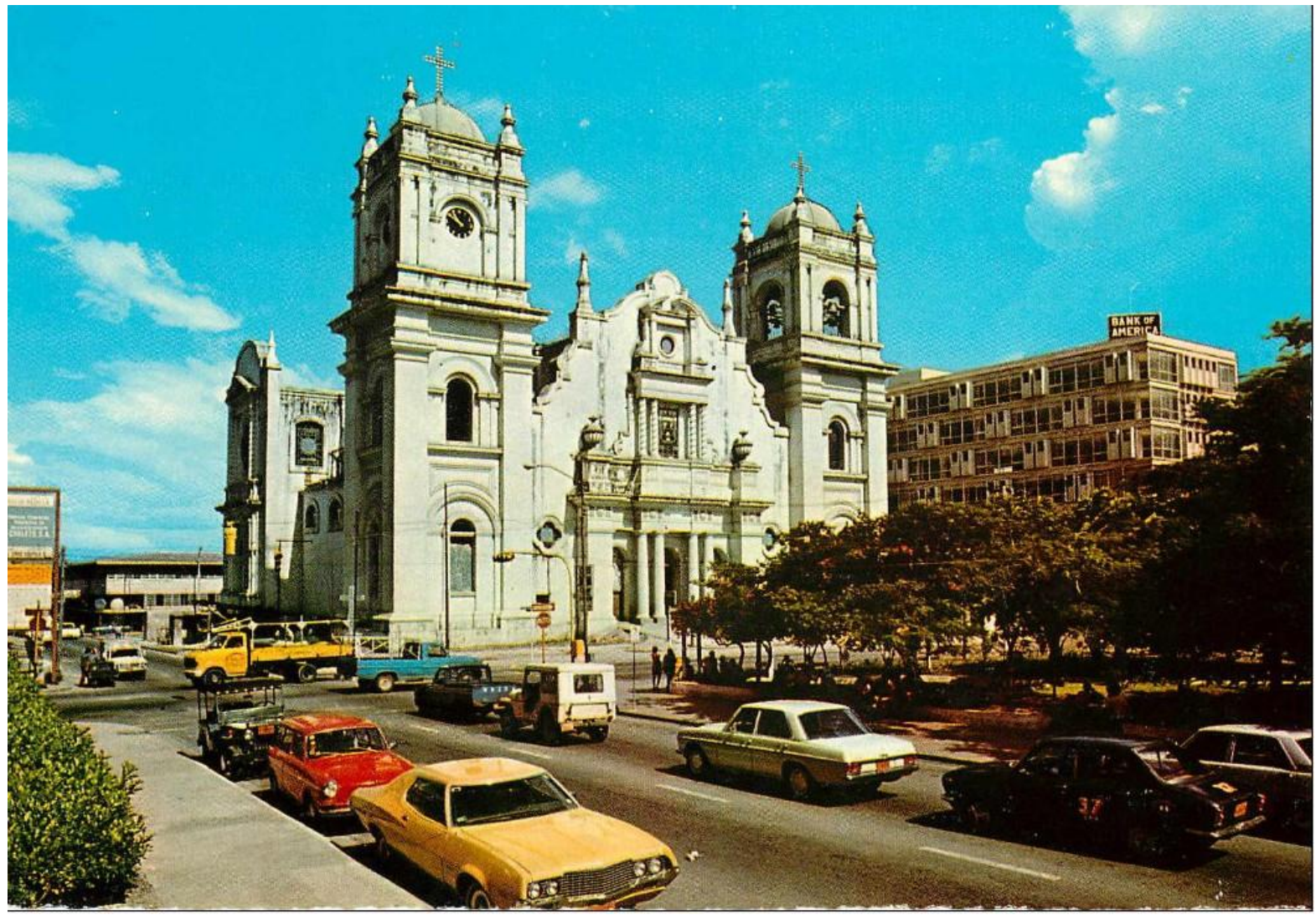

Bellísima postal de los años sesenta de la "Catedral de San Pedro Sula, construida a finales de los años cincuenta. Creemos que mediante esta monumental construcción de estilo neoclásico, los habitantes y autoridades de la ciudad pretendieron rescatar la herencia colonial de la urbe, para tratar de confrontarla contra la apabullante arquitectura de estilo norteamericano que pulula por toda la localidad. Efectivamente, desde su construcción, se ha convertido en un importante referente e icono artístico y patrimonial de la "Ciudad Industrial". 
Artigo original

Hegemonia - Revista Eletrônica do Programa de Mestrado em Direitos Humanos, Cidadania e Violência/Ciência Política do Centro Universitário Unieuro ISSN: $1809-1261$

UNIEURO, Brasília, número 24, Julho a Dezembro de 2018, pp. 110-259.

POSTAL 51

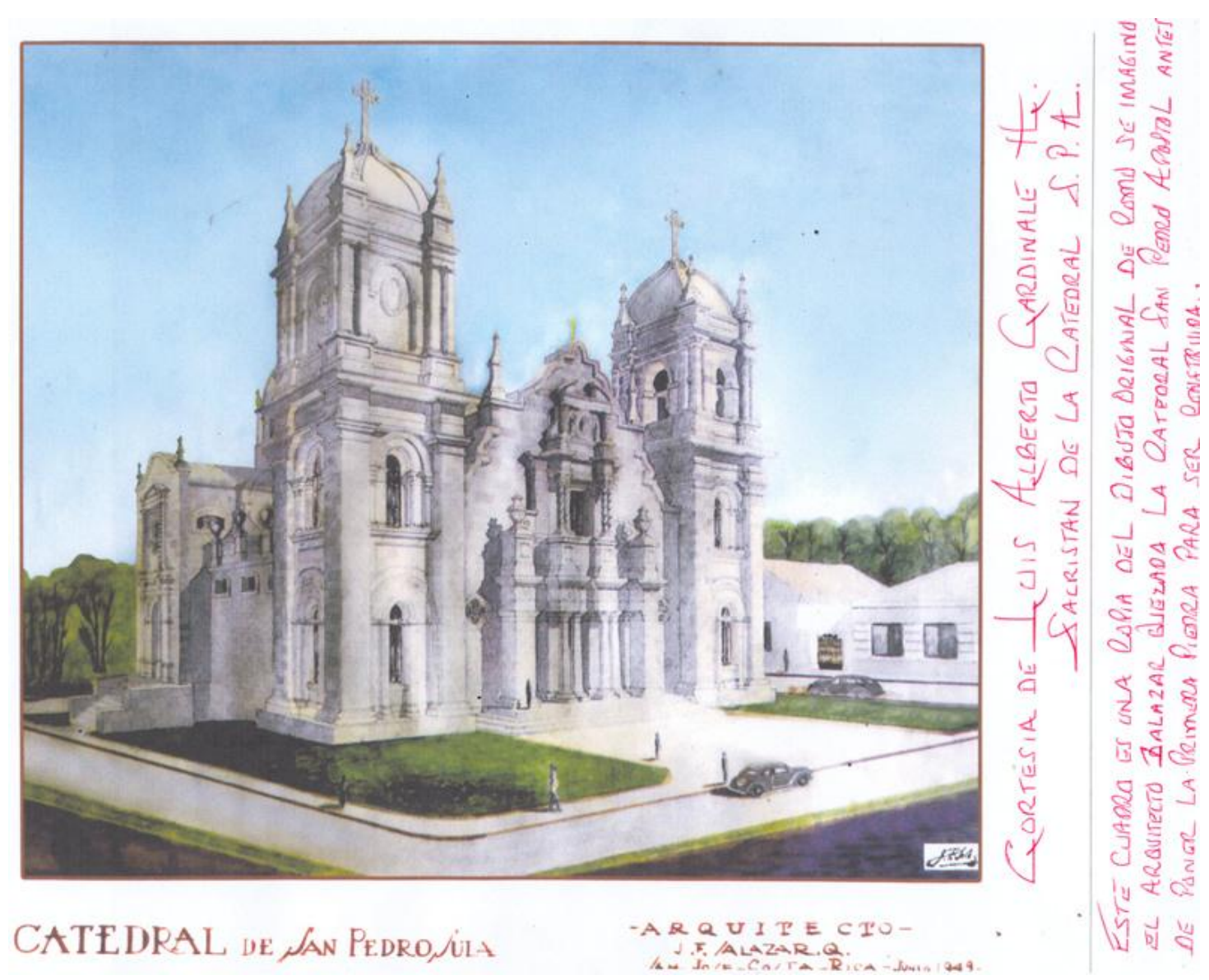

Tarjeta postal de 1965, con la estampa del diseño original de la Catedral de San Pedro Sula, obra del arquitecto Salazar, y que fue remitida por el sacristán de la catedral. 
Artigo original

Hegemonia - Revista Eletrônica do Programa de Mestrado em Direitos Humanos, Cidadania e Violência/Ciência Política do Centro Universitário Unieuro ISSN: $1809-1261$

UNIEURO, Brasília, número 24, Julho a Dezembro de 2018, pp. 110-259.

\section{POSTAL 52}

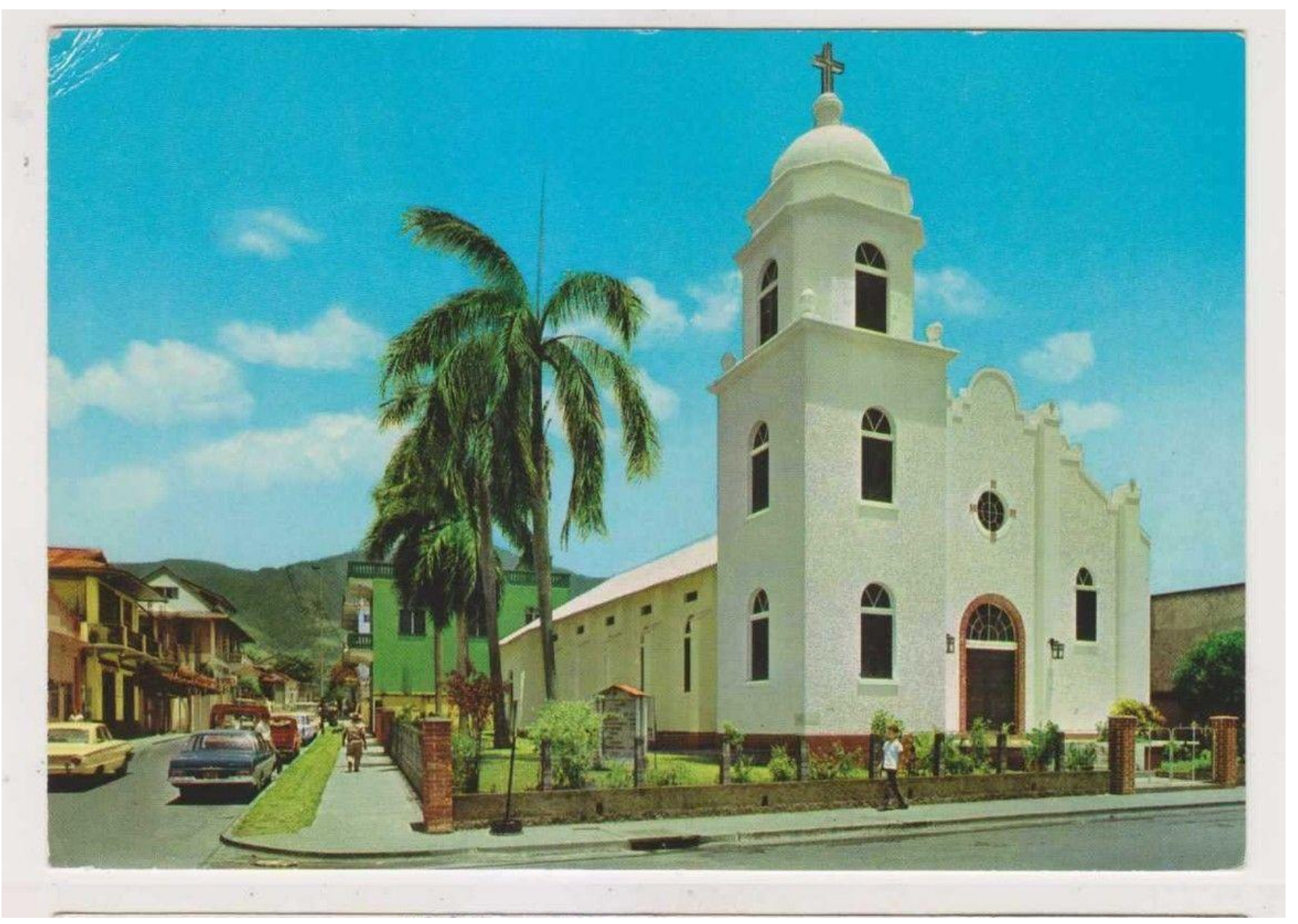

Bellísima postal de los años sesenta de la "Iglesia Evangélica" de San Pedro Sula, que nos permite ver dos detalles importantes: en primer lugar, de nuevo la influencia arquitectónica norteamericana, y en segundo lugar, la llegada de la denominación protestante a un país que antes de la "Banana Republic" era enteramente católico. 
Artigo original

Hegemonia - Revista Eletrônica do Programa de Mestrado em Direitos Humanos, Cidadania e Violência/Ciência Política do Centro Universitário Unieuro ISSN: $1809-1261$

UNIEURO, Brasília, número 24, Julho a Dezembro de 2018, pp. 110-259.

POSTAL 53

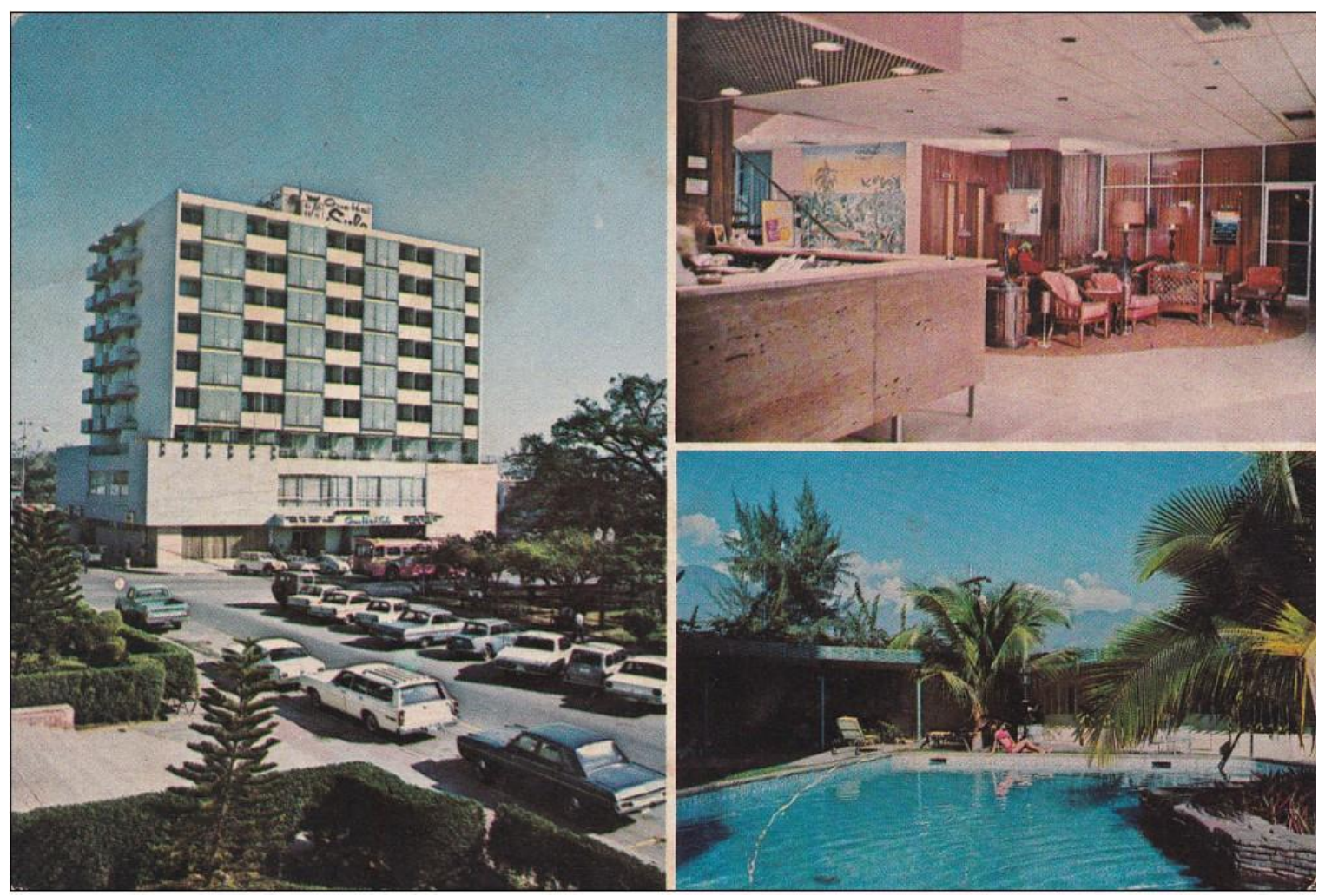

Tarjeta postal de inicios de los años setenta, que en tres estampas nos muestra uno de los iconos arquitectónicos impulsados con la modernización urbana de mediados del siglo XX: el legendario "Gran Hotel Sula", posiblemente el primer edificio de grandes dimensiones construido en la ciudad. La postal nos ilustra el repunte que empezó a alcanzar la actividad turística en esos años, así como los cómodos y confortables servicios ofertados, como la zona de bar y restaurante, así como la piscina, todo lo cual invitaba a los extranjeros a visitar los nuevos atractivos turísticos de la "Banana Republic" hondureña. 
Artigo original

Hegemonia - Revista Eletrônica do Programa de Mestrado em Direitos Humanos, Cidadania e Violência/Ciência Política do Centro Universitário Unieuro ISSN: 1809-1261

UNIEURO, Brasília, número 24, Julho a Dezembro de 2018, pp. 110-259.

POSTAL 54

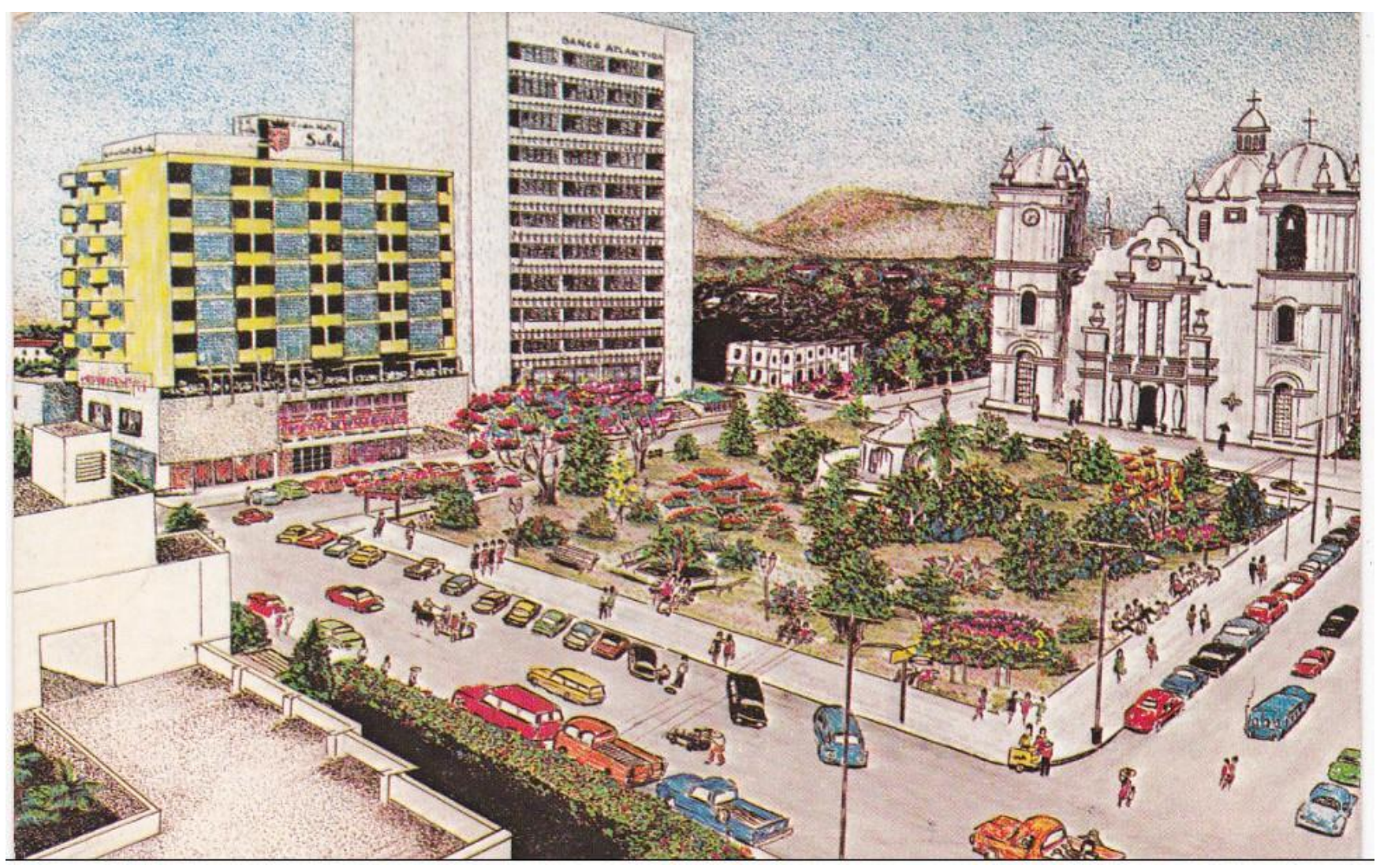

Otra postal en diseño de dibujo de los años ochenta, que expone el mismo espacio del "Gran Hotel Sula", pero ahora acompañado de otro símbolo arquitectónico que denotaba la modernización urbana: el edificio del "Banco Atlántida", por muchos años el edificio más alto de la ciudad. Al lado derecho se observa la imponente catedral, y en primer plano el "Parque Barahona", atestado de vehículos y peatones que reiteraban la gran actividad urbana de San Pedro Sula. 
Artigo original

Hegemonia - Revista Eletrônica do Programa de Mestrado em Direitos Humanos, Cidadania e Violência/Ciência Política do Centro Universitário Unieuro ISSN: 1809-1261

UNIEURO, Brasília, número 24, Julho a Dezembro de 2018, pp. 110-259.

\section{POSTAL 55}

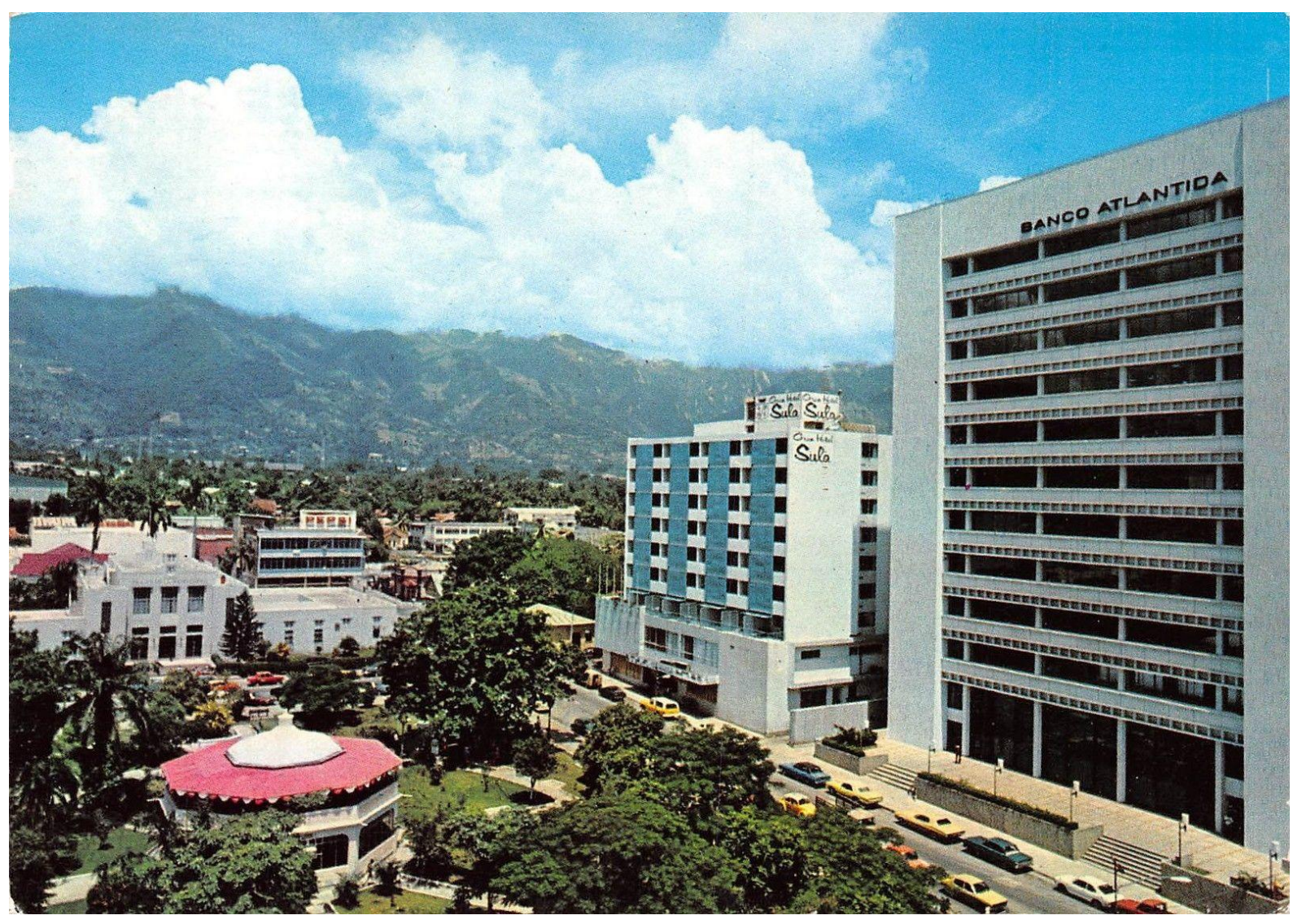

Una postal más de los años ochenta del mismo espacio público: el "Gran Hotel Sula”, el edificio del "Banco Atlántida” y el "Parque Central”. Hacia esos años, San Pedro Sula, influenciada por la febril actividad de las compañías bananeras, se mostraba como la ciudad más pujante de Honduras y Centroamérica. 
Artigo original

Hegemonia - Revista Eletrônica do Programa de Mestrado em Direitos Humanos, Cidadania e Violência/Ciência Política do Centro Universitário Unieuro ISSN: $1809-1261$

UNIEURO, Brasília, número 24, Julho a Dezembro de 2018, pp. 110-259.

POSTAL 56

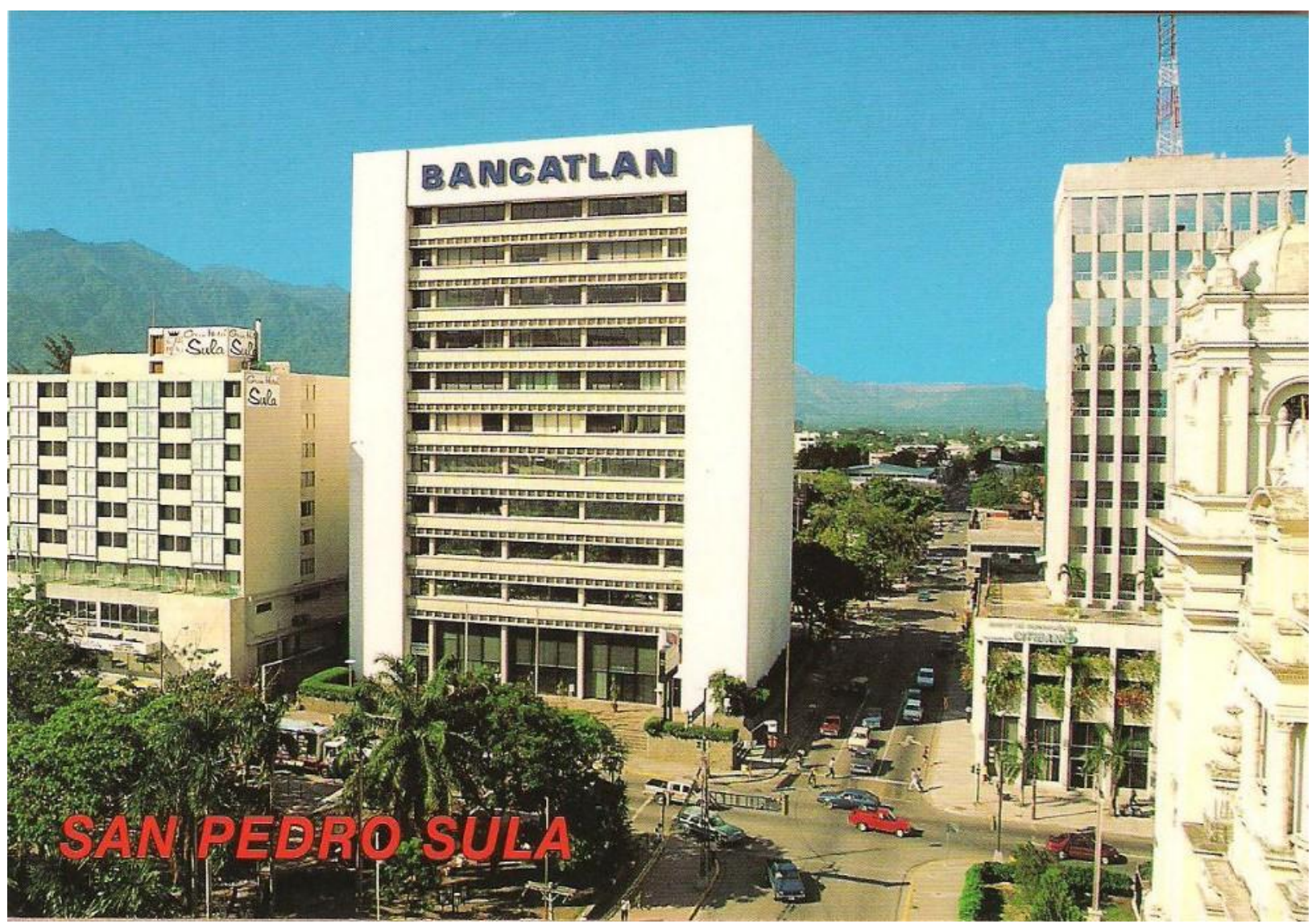

Postal de los años noventa, que retrata nuevamente la expansión urbana de San Pedro Sula como la ciudad más importante del circuito bananero hondureño. 
Artigo original

Hegemonia - Revista Eletrônica do Programa de Mestrado em Direitos Humanos, Cidadania e Violência/Ciência Política do Centro Universitário Unieuro ISSN: 1809-1261

UNIEURO, Brasília, número 24, Julho a Dezembro de 2018, pp. 110-259.

\section{POSTAL 57}

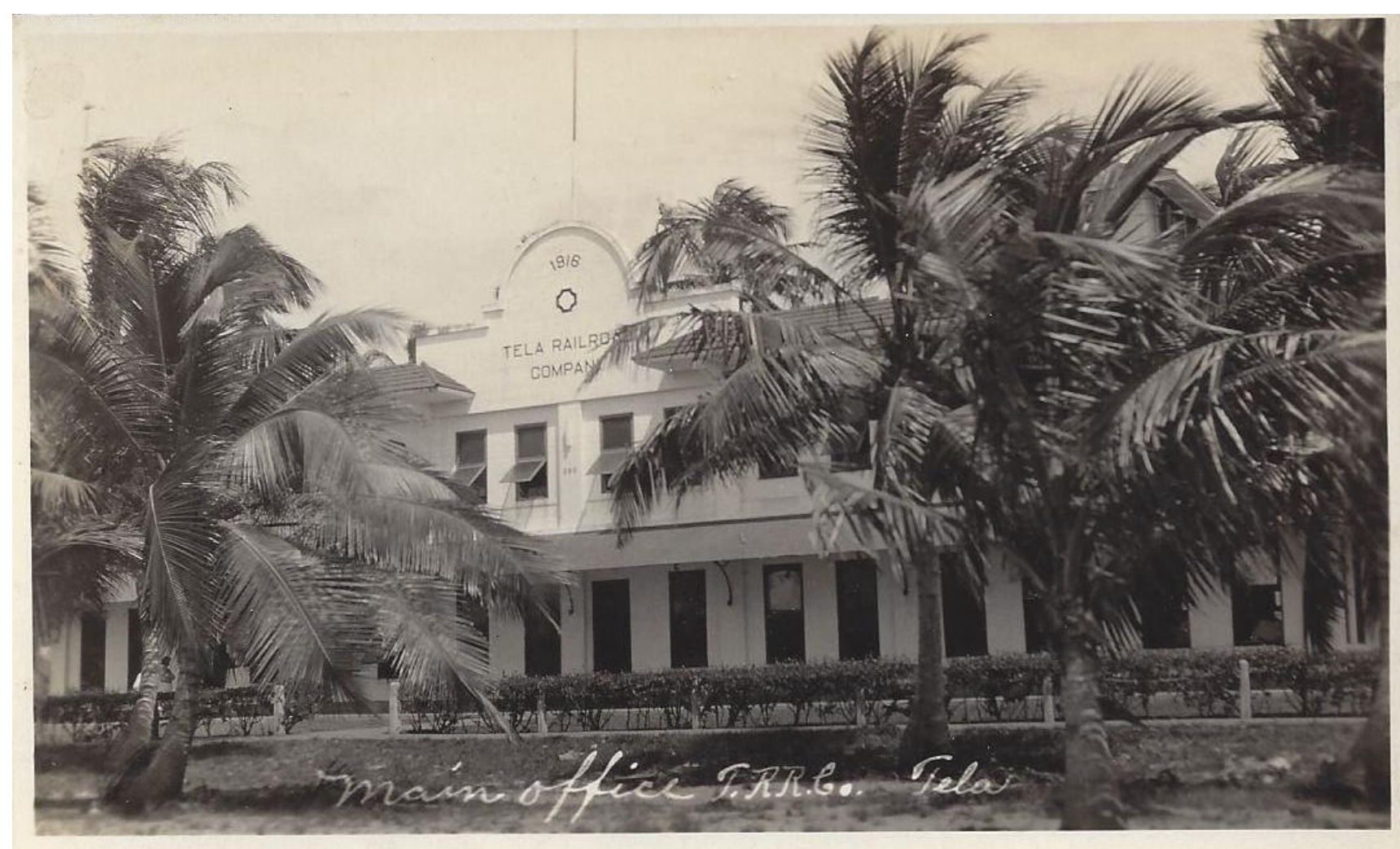

Tarjeta postal de los años treinta del edificio principal de la "Tela Railroad Company", una de las subsidiarias de la "United Fruit Company" en Honduras. Construido en 1916 en estilo "Art Deco", este edificio, recién remodelado y convertido en "Museo de la Historia Bananera" de la ciudad portuaria, fue el epicentro de la actividad administrativa de dicha empresa en Honduras. Ahí se introdujo el sistema de contabilidad y administración de empresas moderna en el país, y en gran medida ahí se fraguó el destino político y económico de la nación. 
Artigo original

Hegemonia - Revista Eletrônica do Programa de Mestrado em Direitos Humanos, Cidadania e Violência/Ciência Política do Centro Universitário Unieuro ISSN: $1809-1261$

UNIEURO, Brasília, número 24, Julho a Dezembro de 2018, pp. 110-259.

POSTAL 58

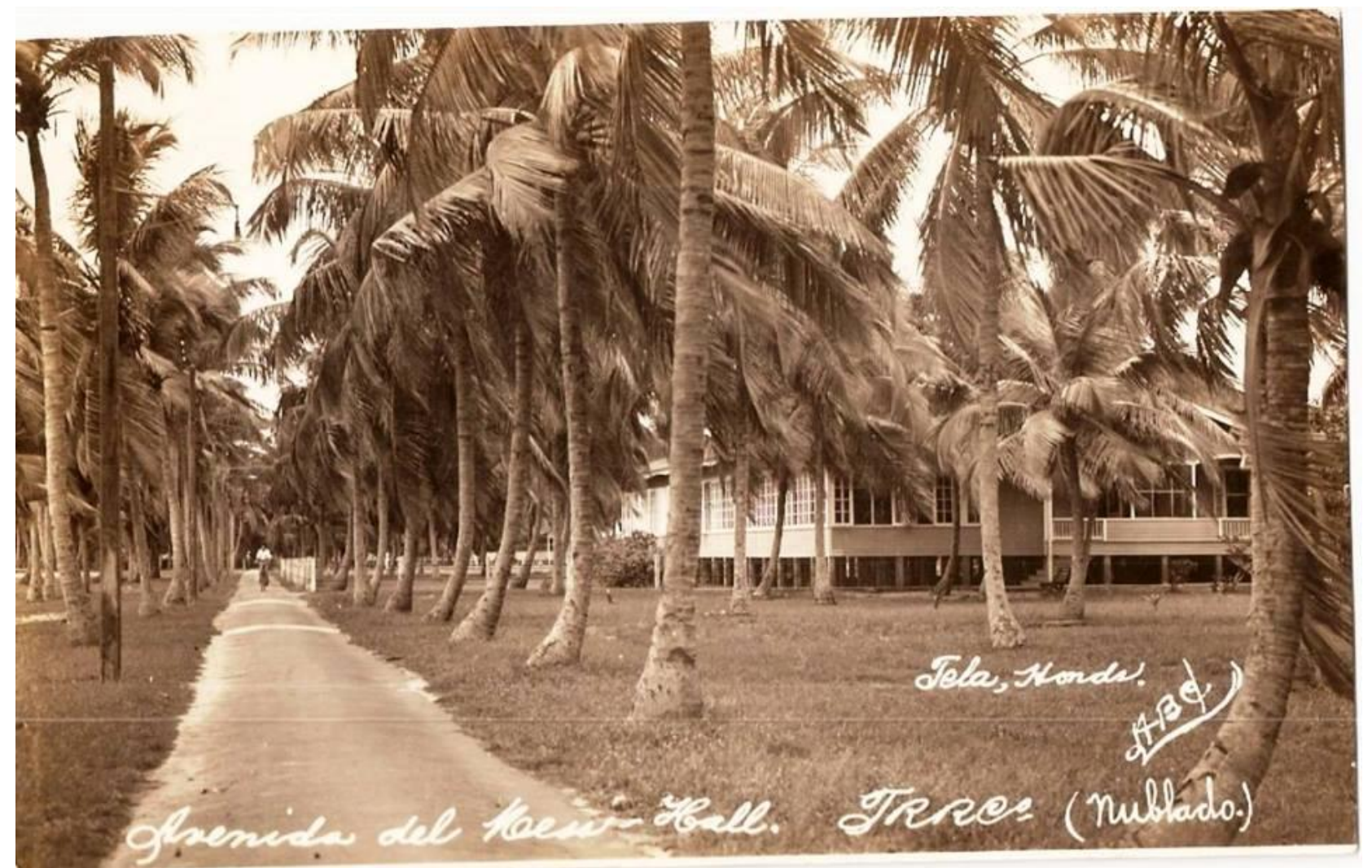

Bella estampa de los años cuarenta de la zona residencial americana de la "Tela Railroad Company", en la ciudad de Tela, con las hermosas cabañas de los funcionarios de la compañía, cuidadosamente engramadas y adornadas con exóticas palmeras, que evoca los "Company Town” de zonas colonizadas por anglosajones, como Hawai o la India. 
Artigo original

Hegemonia - Revista Eletrônica do Programa de Mestrado em Direitos Humanos, Cidadania e Violência/Ciência Política do Centro Universitário Unieuro ISSN: $1809-1261$

UNIEURO, Brasília, número 24, Julho a Dezembro de 2018, pp. 110-259.

POSTAL 59

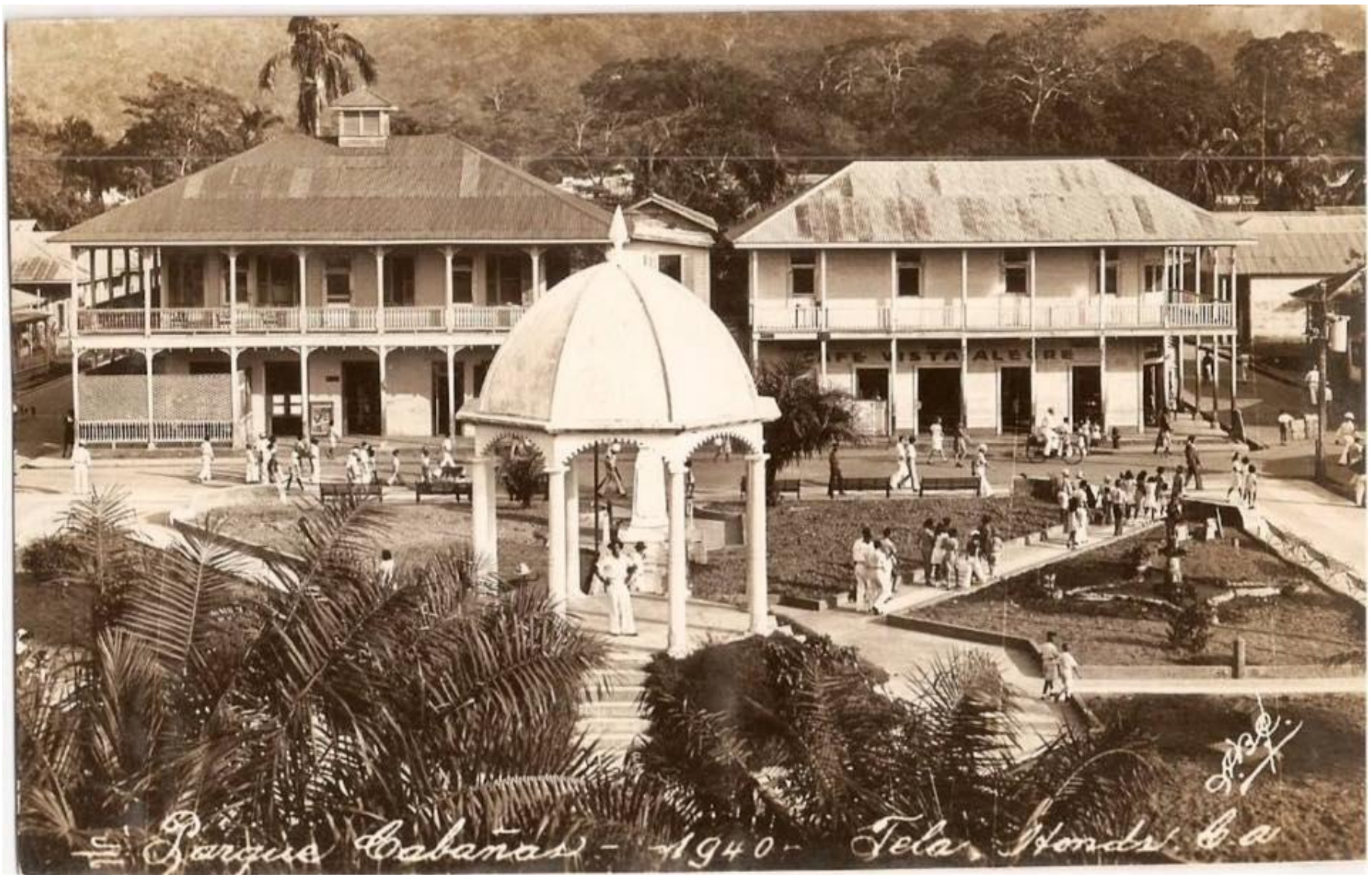

Hermosa tarjeta postal del "Parque Cabañas" de la ciudad de Tela, en 1940, la cual nos permite nuevamente apreciar el modelo arquitectónico introducido por las compañías norteamericanas en la zona. 


\section{Artigo original}

Hegemonia - Revista Eletrônica do Programa de Mestrado em Direitos Humanos, Cidadania e Violência/Ciência Política do Centro Universitário Unieuro ISSN: 1809-1261

UNIEURO, Brasília, número 24, Julho a Dezembro de 2018, pp. 110-259.

\section{POSTAL 60}

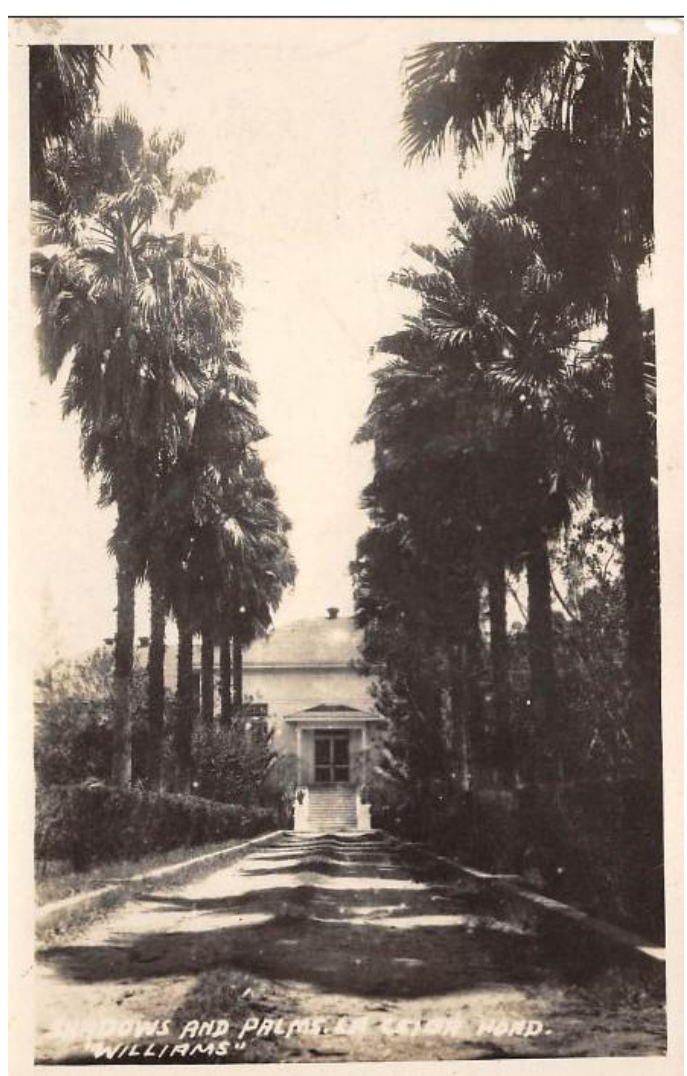

Importante tarjeta postal de los años cuarenta, obra del fotógrafo Arnold Teodhore Williams, de la elegante y señorial mansión de los hermanos Vaccaro en la ciudad de La Ceiba, los fundadores de la "Standard Fruit Company". Como se puede admirar, la residencia es una copia del estilo de las mansiones señoriales de Nueva Orleáns de donde procedían los Vaccaro-, en estilo palacete, antecedida por una avenida de palmeras, jardineras y arriates, como en las casas de los esclavistas del sur de los Estrados Unidos. 
Artigo original

Hegemonia - Revista Eletrônica do Programa de Mestrado em Direitos Humanos, Cidadania e Violência/Ciência Política do Centro Universitário Unieuro ISSN: 1809-1261

UNIEURO, Brasília, número 24, Julho a Dezembro de 2018, pp. 110-259.

POSTAL 61

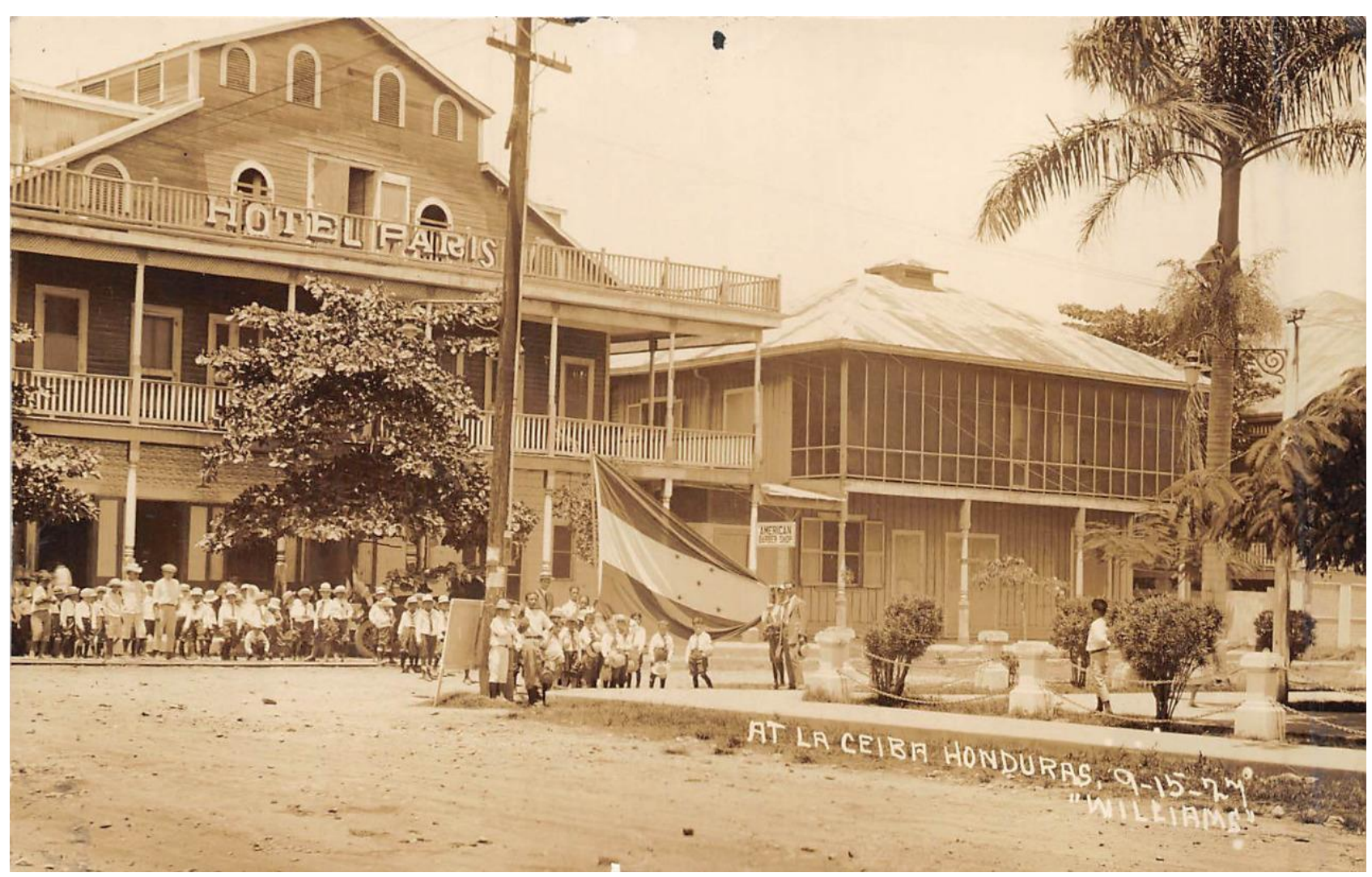

Otra Espléndida tarjeta postal de 1927, editada por el fotógrafo Arnold Teodhore Williams, que muestra un acto cívico de unos escolares hondureños que portan la bandera hondureña un 15 de septiembre, y al fondo el histórico edificio que albergaba el histórico "Hotel París", frente al "Parque Central" de la ciudad de La Ceiba, Atlántida, de estilo arquitectónico norteamericano. 


\section{Artigo original}

Hegemonia - Revista Eletrônica do Programa de Mestrado em Direitos Humanos, Cidadania e Violência/Ciência Política do Centro Universitário Unieuro ISSN: 1809-1261

UNIEURO, Brasília, número 24, Julho a Dezembro de 2018, pp. 110-259.

POSTAL 62

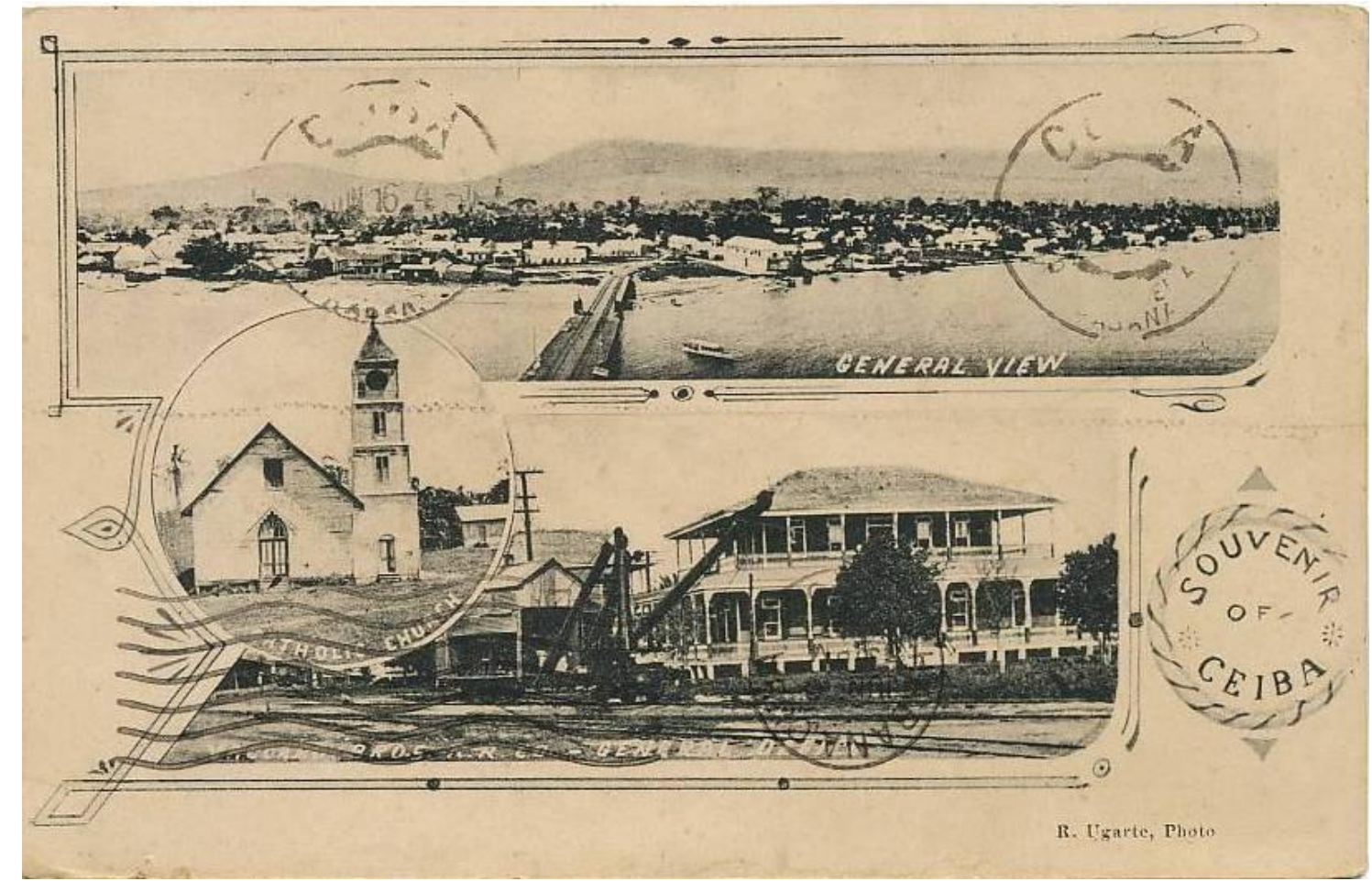

Encantadora tarjeta postal en collage de distintas escenas urbanas de la Ciudad de la Ceiba, la "Novia de Honduras", editada en 1908 por el fotógrafo hondureño don Rafael Ugarte. Se aprecian en la escena superior una panorámica aérea del muelle de la ciudad portuaria, y abajo, la antigua parroquia de la ciudad y el viejo edificio del Palacio Municipal. Esta ciudad puerto se convirtió en epicentro de la actividad bananera en Honduras desde finales del siglo XIX, y estaba más conectada con Nueva Orleáns que con la misma Tegucigalpa. De alguna manera, esta ciudad marcó grandemente el apelativo e imaginario de "Banana Republic" atribuido a Honduras en el extranjero. 


\section{Artigo original}

Hegemonia - Revista Eletrônica do Programa de Mestrado em Direitos Humanos, Cidadania e Violência/Ciência Política do Centro Universitário Unieuro ISSN: 1809-1261

UNIEURO, Brasília, número 24, Julho a Dezembro de 2018, pp. 110-259.

\section{POSTAL 63}

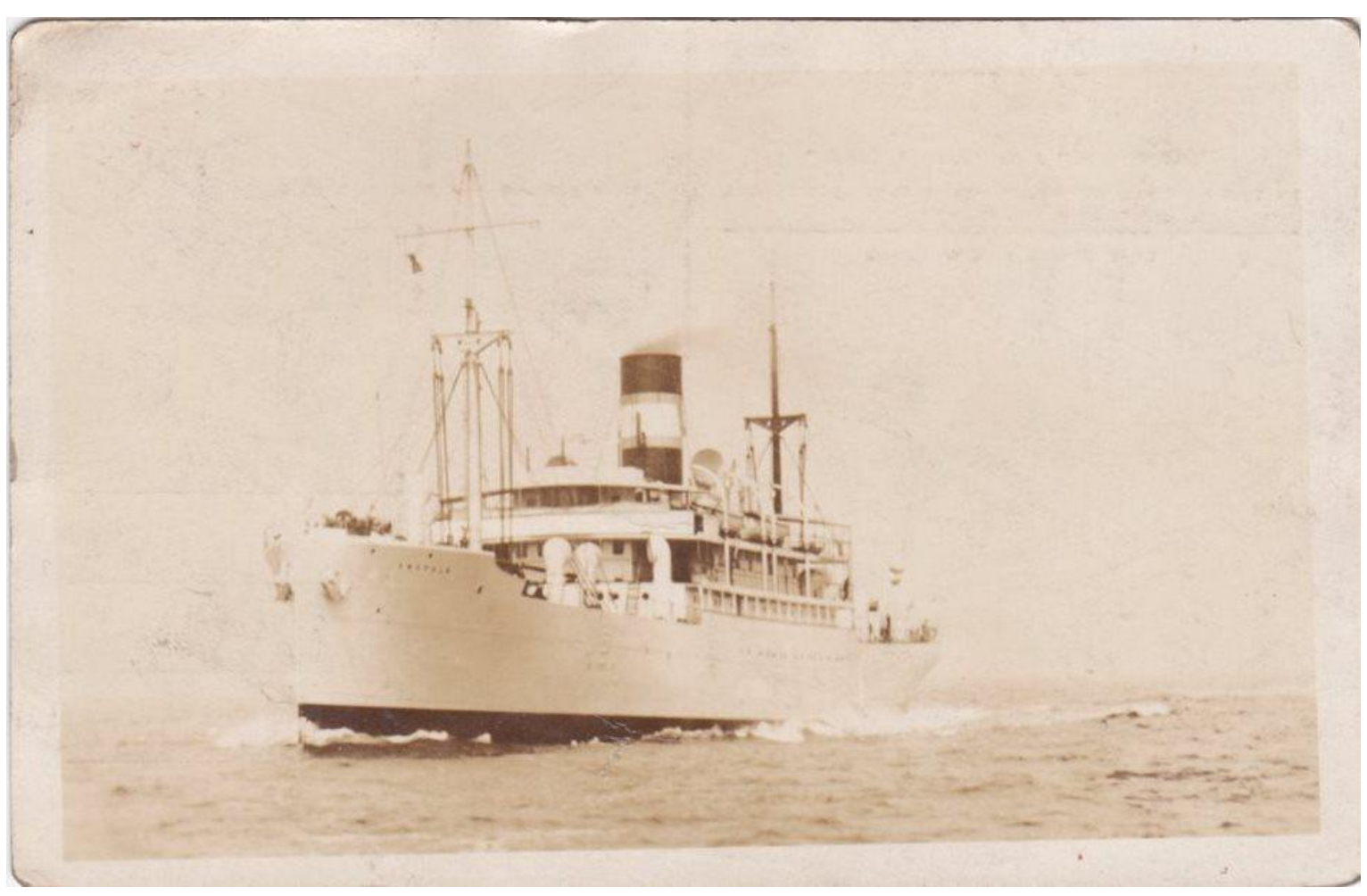

Un barco carguero de bananos, perteneciente a la flota de la "Standard Fruit Company", conocida como la "Vaccaro Line", en esta tarjeta postal editada por dicha empresa en 1925. Era tan trascendental el papel de los barcos, que incluso eran protagonistas de la portada de una tarjeta postal, para mostrar a toda la población del planeta que estas embarcaciones eran las que lograban el prodigio de llevar las bananas a todo el mundo. La postal fue remitida desde La Ceiba hasta Chicago, curiosamente escrita en italiano, lo que nos recuerda el cosmopolitismo y modernización que se experimentaba en estas zonas de influencia de la "Banana Republic". 


\section{Artigo original}

Hegemonia - Revista Eletrônica do Programa de Mestrado em Direitos Humanos, Cidadania e Violência/Ciência Política do Centro Universitário Unieuro ISSN: 1809-1261

UNIEURO, Brasília, número 24, Julho a Dezembro de 2018, pp. 110-259.

\section{POSTAL 64}

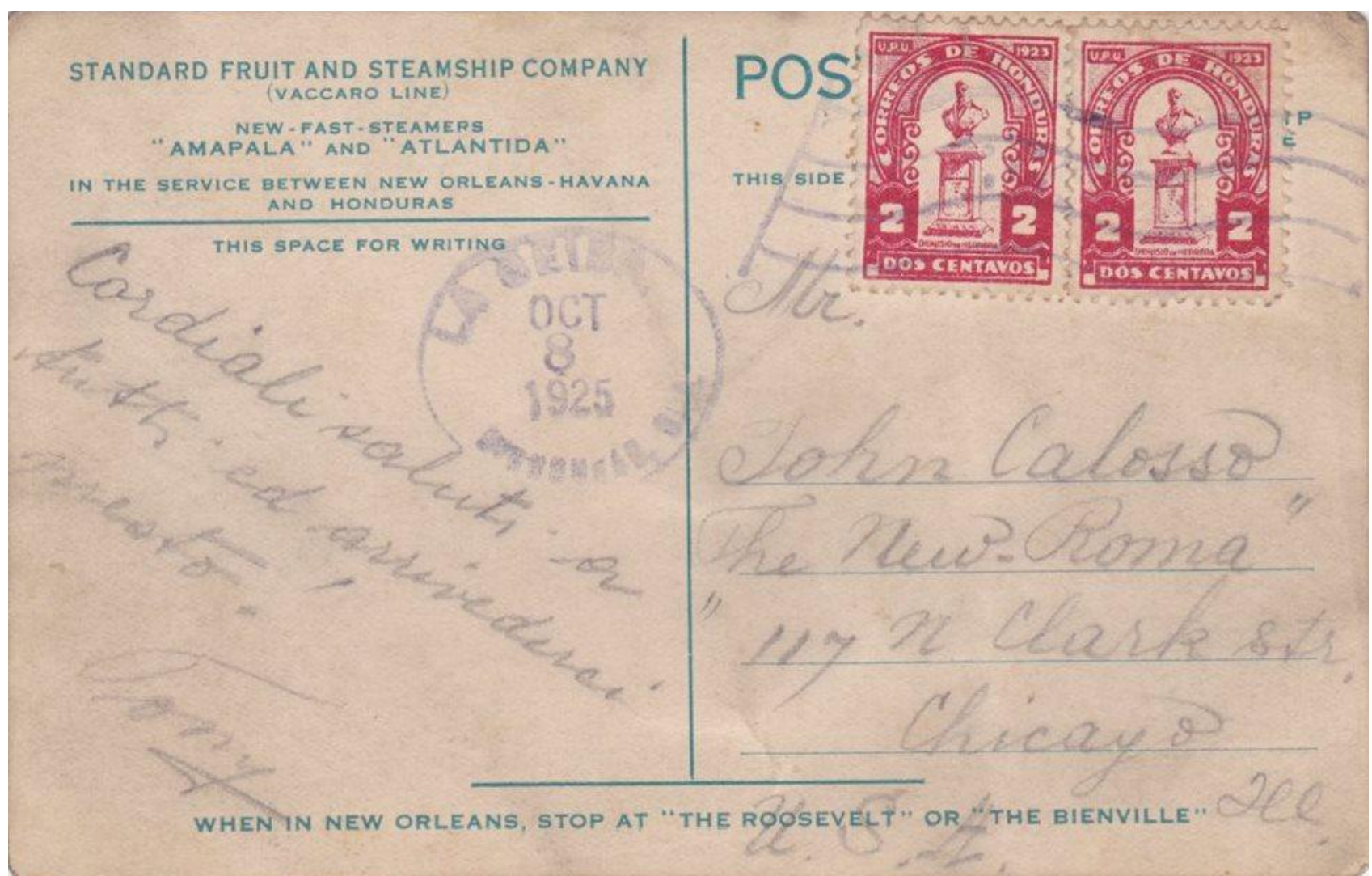

Reverso de la anterior tarjeta postal del barco carguero de bananos, donde se aprecian los datos de remisión de la tarjeta postal, así como los datos editoriales que ratifican que las compañías bananeras imprimían tarjetas postales con fines publicitarios y de propaganda de sus empresas, con el fin de transmitir imaginarios provechosos de las fruteras. 


\section{Artigo original}

Hegemonia - Revista Eletrônica do Programa de Mestrado em Direitos Humanos, Cidadania e Violência/Ciência Política do Centro Universitário Unieuro ISSN: 1809-1261

UNIEURO, Brasília, número 24, Julho a Dezembro de 2018, pp. 110-259.

\section{POSTAL 65}

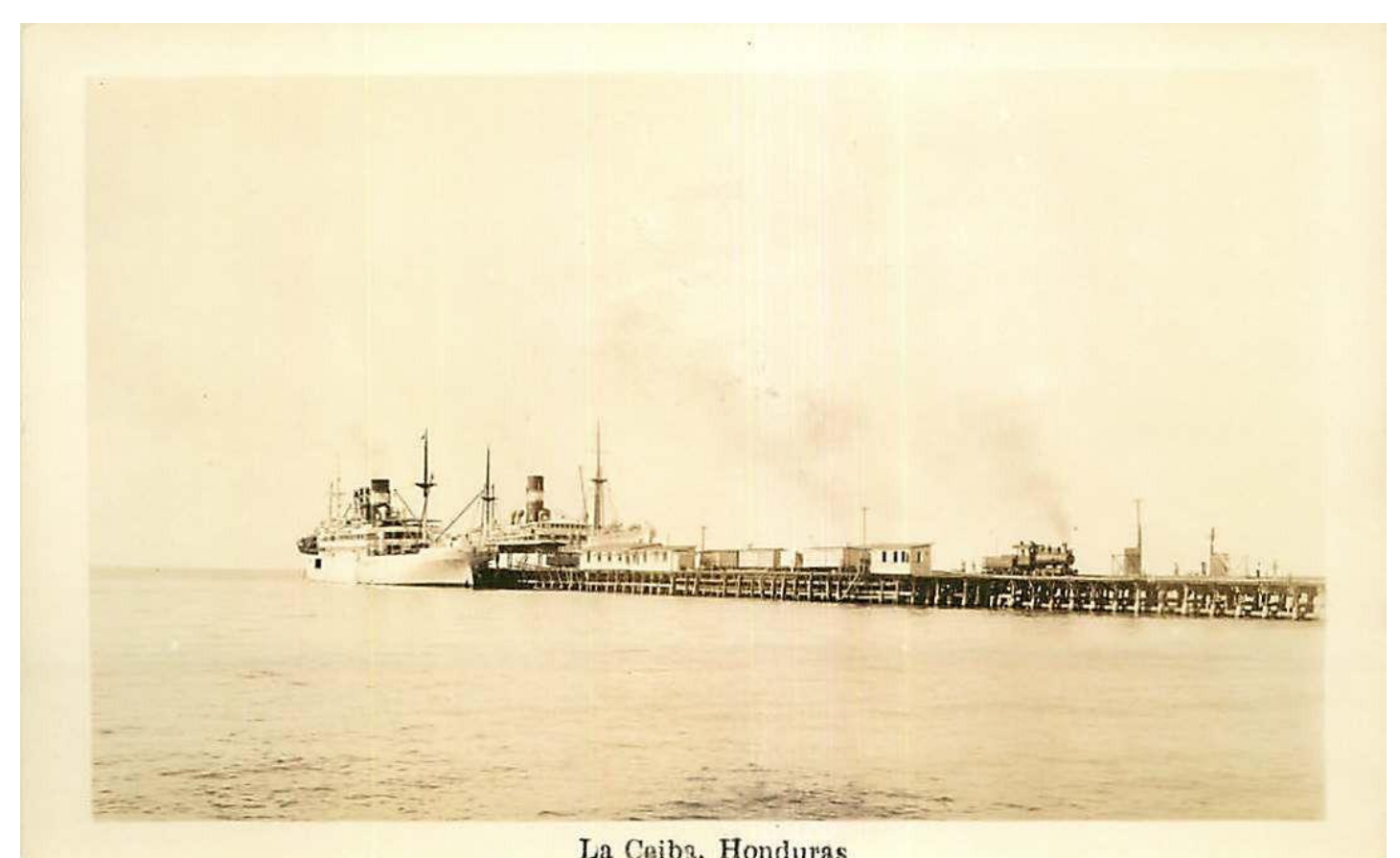

Elegante postal del antiguo muelle del Puerto de La Ceiba, durante décadas puerta de entrada de Honduras al comercio y exportación de bananos al resto del mundo, adonde arriban los barcos de la "Vaccaro Line" y de la legendaria "Flota Blanca" de la UFCO. La ida y venida de estos barcos traía los artefactos de la modernidad a Honduras (modas, aparatos modernos, libros, películas, vehículos, motocicletas, máquinas), pero igualmente se "llevaba" la riqueza más preciada: la producción de frutas (especialmente bananas, pero también piñas, naranjas, mangos), a costos bajísimos que solamente acrecentaban las ganancias y plusvalía de las empresas extranjeras, esquilmando a obreros y a la hacienda pública del Estado de Honduras, es decir, configurando con esa dialéctica la formación de la llamada "Banana Republic". 
Artigo original

Hegemonia - Revista Eletrônica do Programa de Mestrado em Direitos Humanos, Cidadania e Violência/Ciência Política do Centro Universitário Unieuro ISSN: $1809-1261$

UNIEURO, Brasília, número 24, Julho a Dezembro de 2018, pp. 110-259.

POSTAL 66

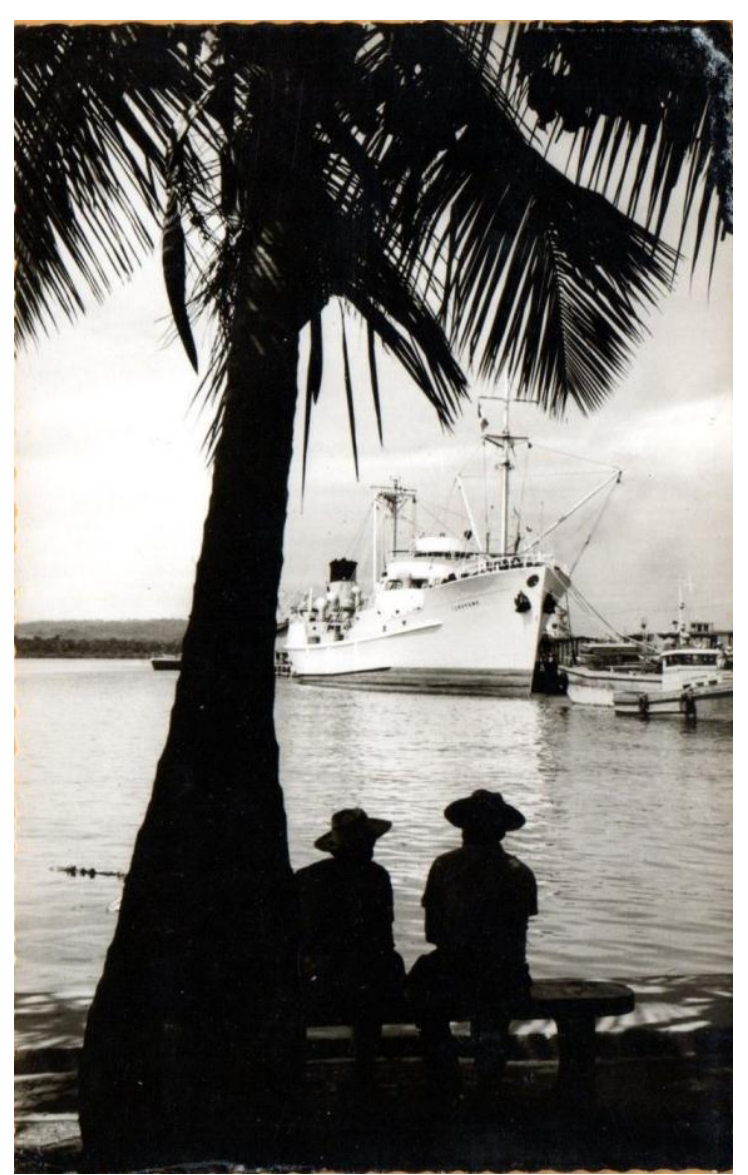

Sensacional y nostálgica tarjeta postal de dos campeños tomando la sombra en unos cocoteros frente al muelle de La Ceiba, en el que se perfila un colosal barco de las compañías. 
Artigo original

Hegemonia - Revista Eletrônica do Programa de Mestrado em Direitos Humanos, Cidadania e Violência/Ciência Política do Centro Universitário Unieuro ISSN: $1809-1261$

UNIEURO, Brasília, número 24, Julho a Dezembro de 2018, pp. 110-259.

\section{POSTAL 67}

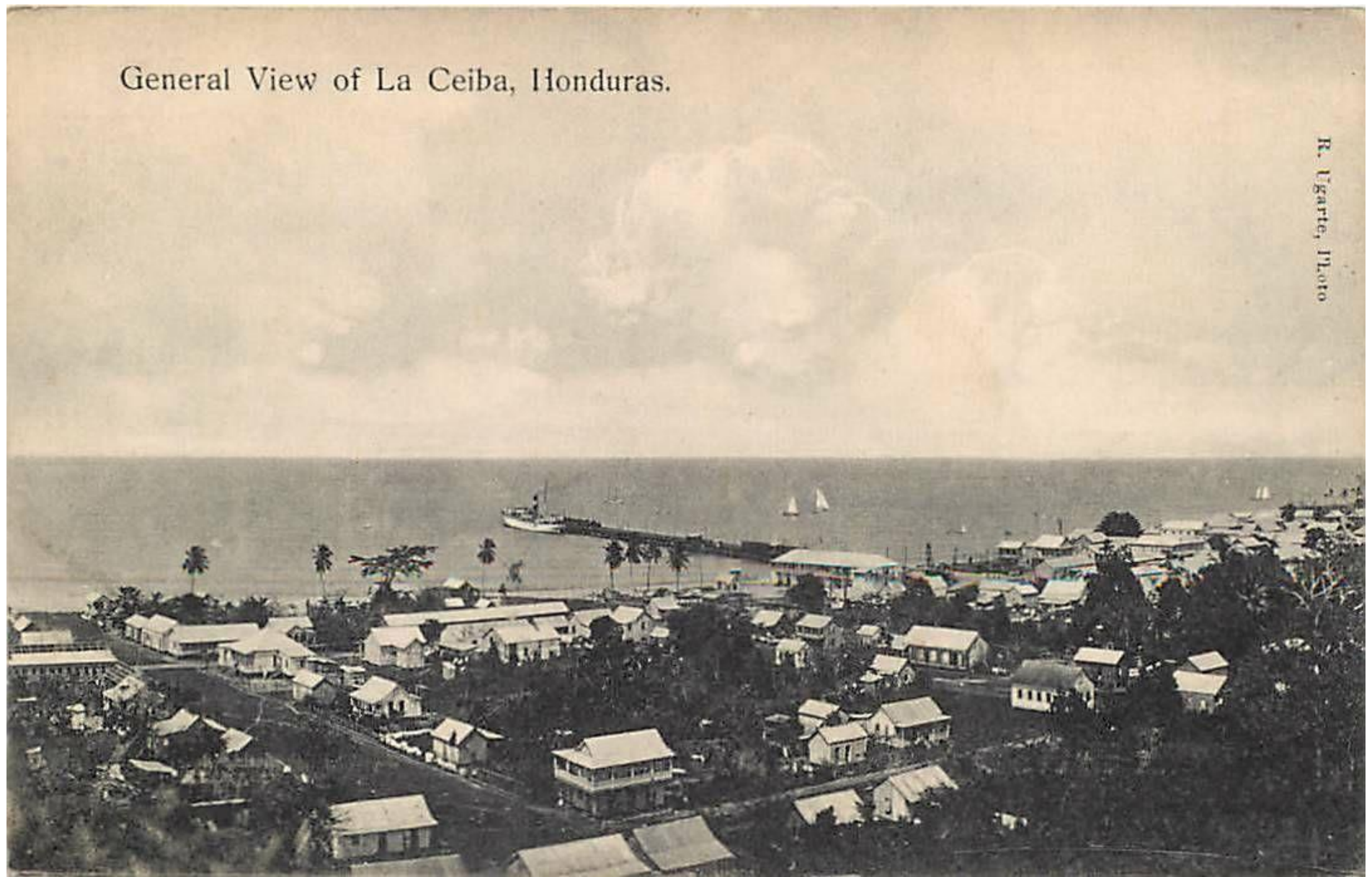

Bella postal panorámica del muelle y puerto de la Ciudad de La Ceiba, editada por el artista fotógrafo hondureño don Rafael Ugarte, de 1910. Se aprecian las construcciones de casas de madera y techos de zinc, y al fondo, uno de los barcos de la compañía. 
Artigo original

Hegemonia - Revista Eletrônica do Programa de Mestrado em Direitos Humanos, Cidadania e Violência/Ciência Política do Centro Universitário Unieuro ISSN: $1809-1261$

UNIEURO, Brasília, número 24, Julho a Dezembro de 2018, pp. 110-259.

\section{POSTAL 68}

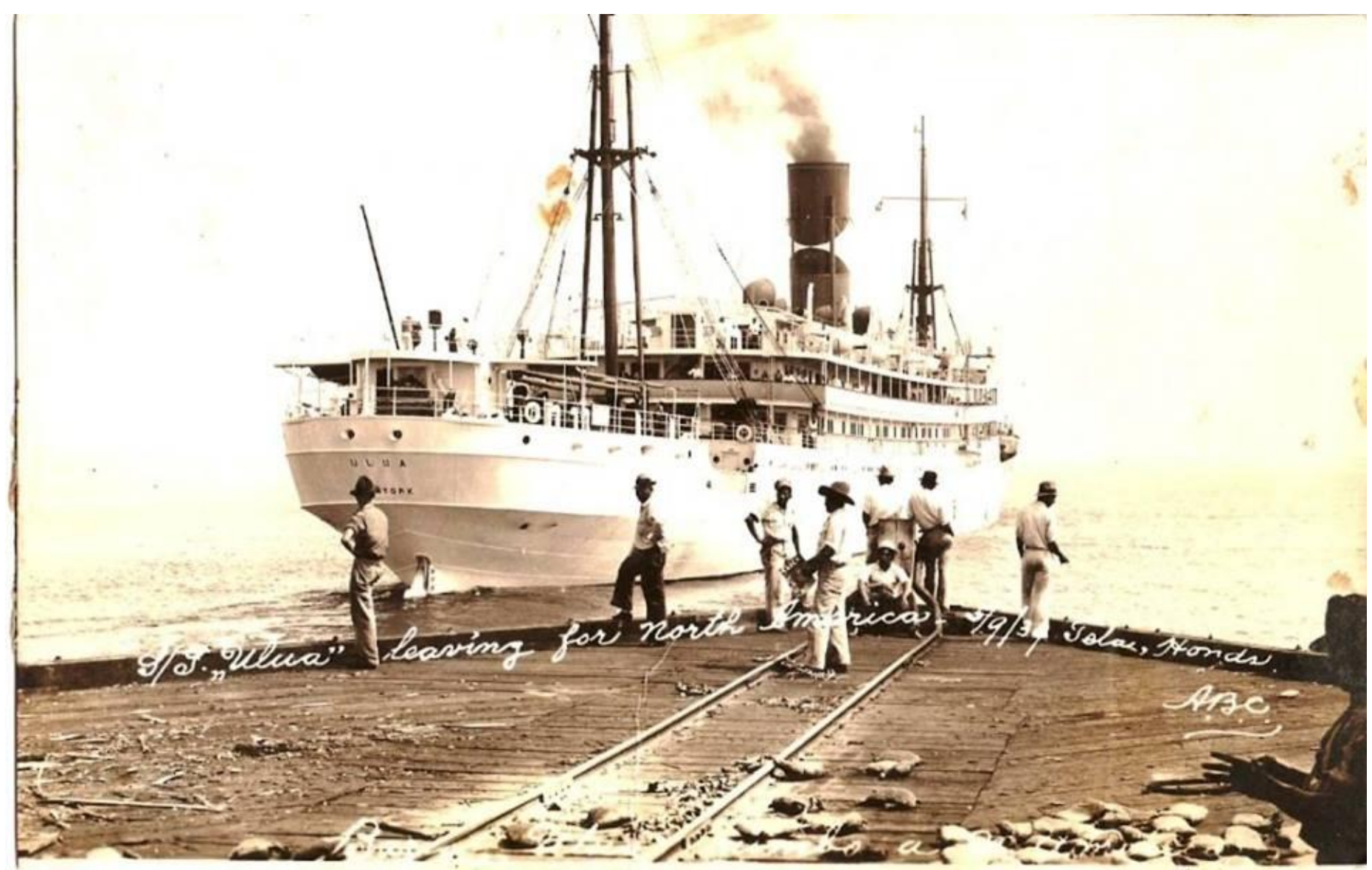

El barco "Ulúa" de la Tela Railroad Company, anclado en el muelle de la ciudad bananera de Tela, y en primer plano, un grupo de obreros esperando comenzar labores de carga y descarga, en 1934, en esta hermosa postal. Los barcos fueron uno de los artefactos más palpables y representativos de la llegada de la "Modernidad" a las "Banana Republic". 


\section{Artigo original}

Hegemonia - Revista Eletrônica do Programa de Mestrado em Direitos Humanos, Cidadania e Violência/Ciência Política do Centro Universitário Unieuro ISSN: 1809-1261

UNIEURO, Brasília, número 24, Julho a Dezembro de 2018, pp. 110-259.

\section{POSTAL 69}

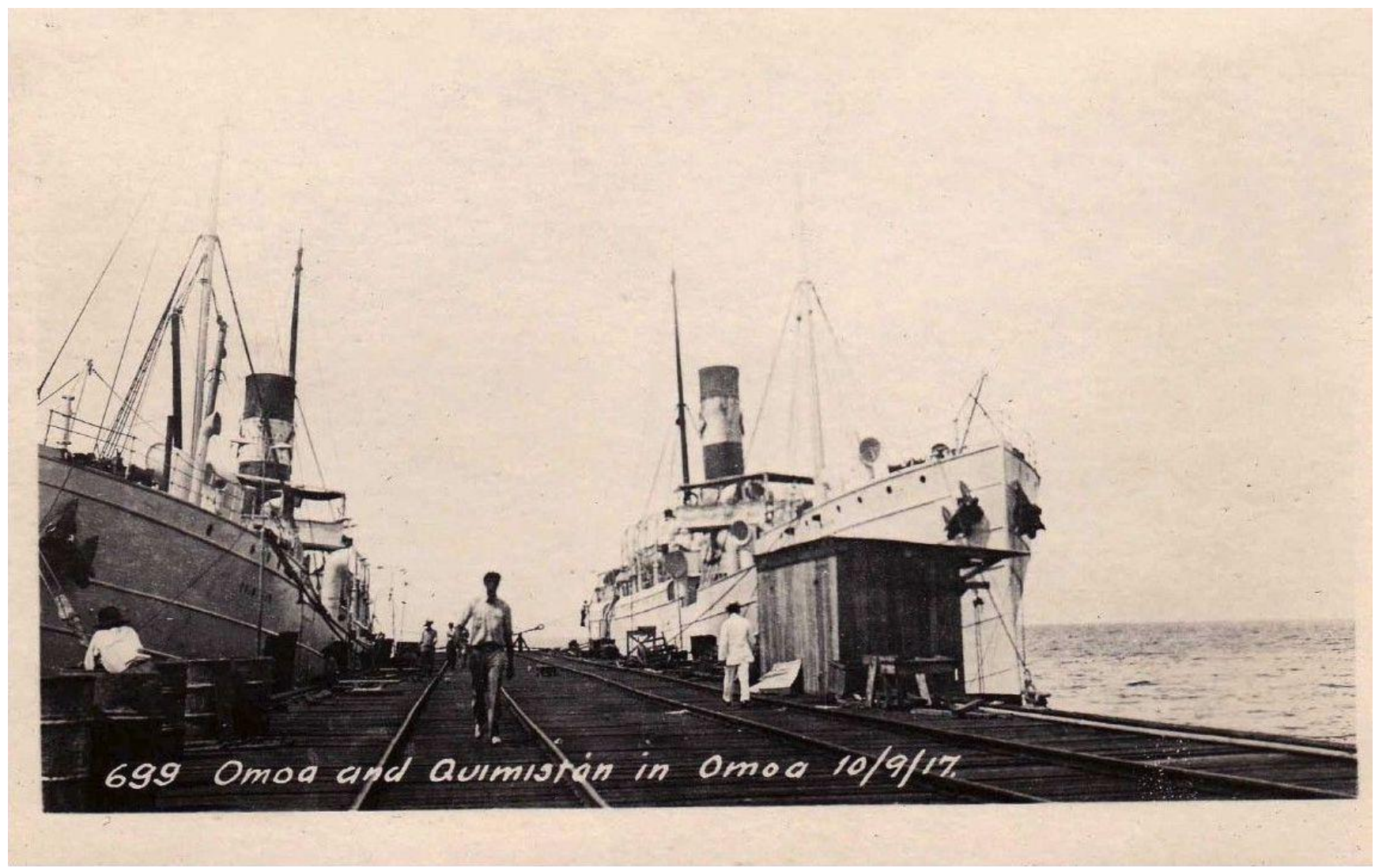

En esta otra postal de 1917, los barcos "Omoa" y "Quimistán" anclados en el muelle de Puerto Cortés. Estos barcos fueron los que llevaron el banano a todo el mundo, y convirtieron a esa fruta en la más consumida y comercializada a nivel mundial en la primera mitad del siglo XX. 
Artigo original

Hegemonia - Revista Eletrônica do Programa de Mestrado em Direitos Humanos, Cidadania e Violência/Ciência Política do Centro Universitário Unieuro ISSN: $1809-1261$

UNIEURO, Brasília, número 24, Julho a Dezembro de 2018, pp. 110-259.

\section{POSTAL 70}

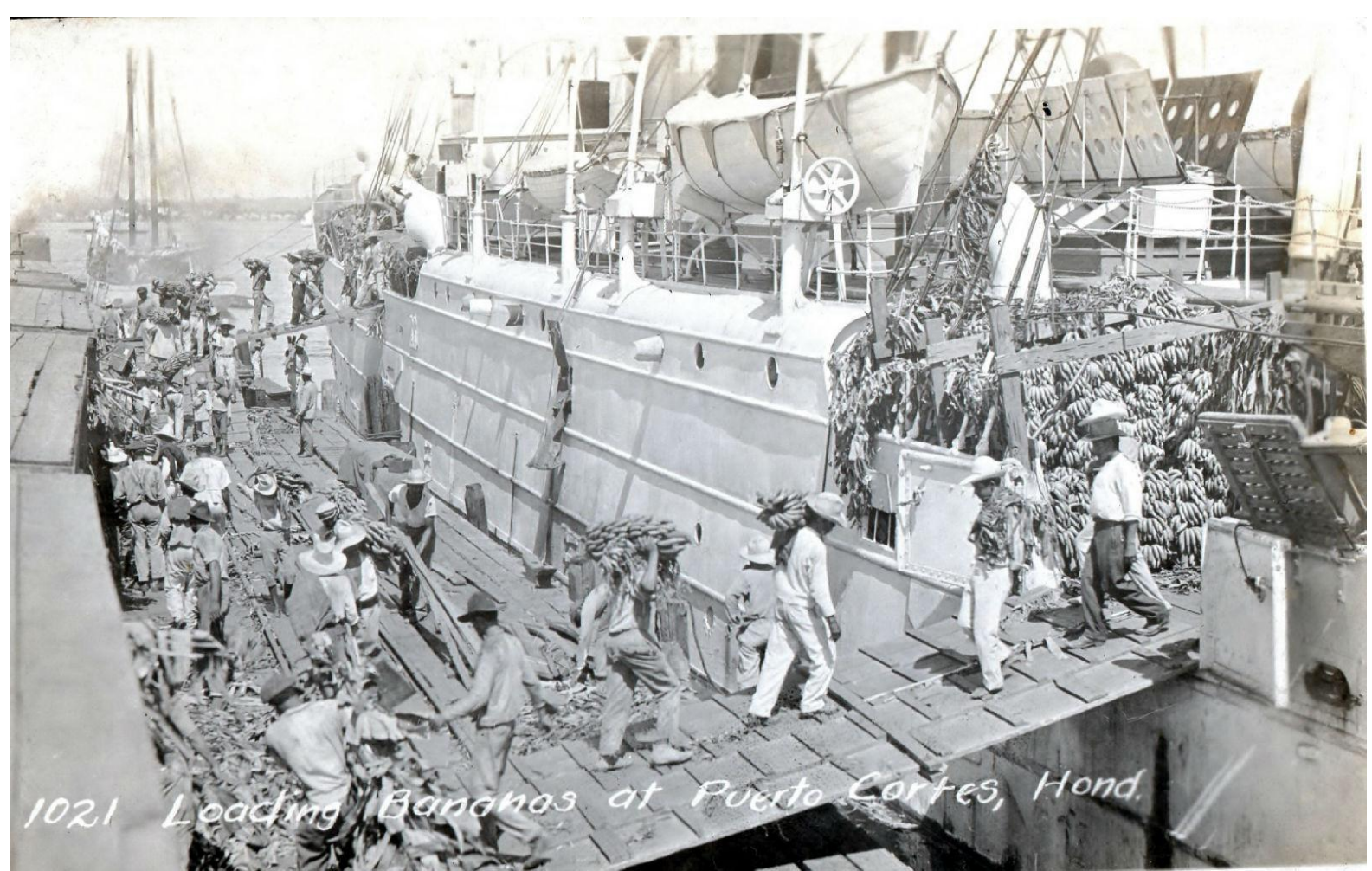

Una postal de las más hermosas: obreros cargando bananos en un barco en el muelle de Puerto Cortés en 1925 . Esta faena de cargar los bananos desde los vagones del ferrocarril hasta las bodegas de los barcos era de las más extenuantes y agotadoras, y las condiciones laborales verdaderamente precarias, por eso fue en los muelles que

se fraguaron la mayoría de protestas y huelgas bananeras. Esa fue una de las respuestas reivindicadoras de los hondureños en contra de la cultura hegemónica de "Banana Republic" impuesta por las compañías transnacionales. 


\section{Artigo original}

Hegemonia - Revista Eletrônica do Programa de Mestrado em Direitos Humanos, Cidadania e Violência/Ciência Política do Centro Universitário Unieuro ISSN: 1809-1261

UNIEURO, Brasília, número 24, Julho a Dezembro de 2018, pp. 110-259.

\section{POSTAL 71}

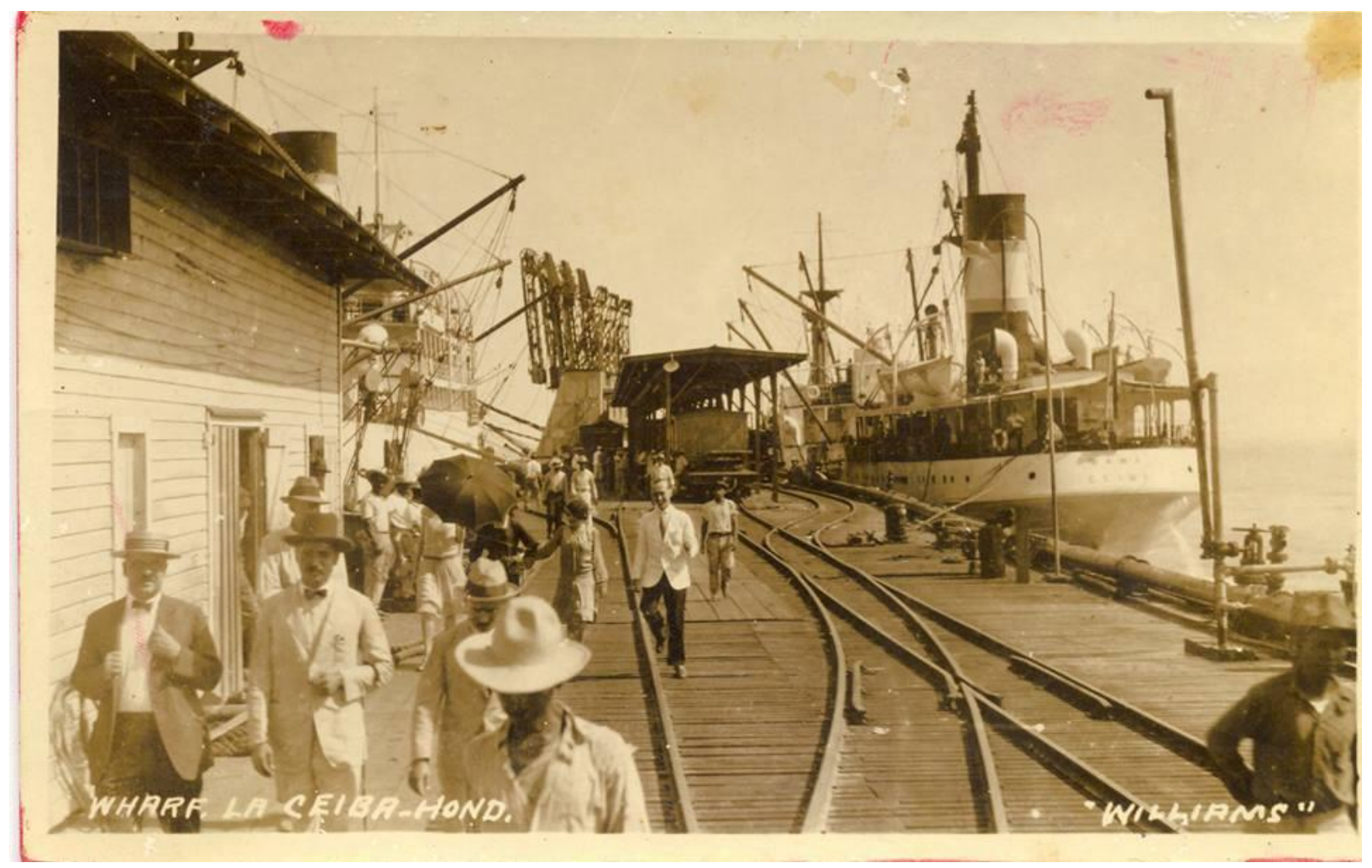

Otra bellísima postal de los años veinte, obra del inmejorable artista fotógrafo Arnold Teodhore Williams, que ilustra un momento relevante y protocolario: la llegada de funcionarios norteamericanos, impecablemente vestidos con traje y corbata y sobreros de galleta y de panamá, desafiando el infernal calor tropical de la costa norte hondureña. Estos modos de vestir y prácticas culturales eran necesarias para imponer no solamente la etiqueta, sino también para hacer valer los modos y usos culturales hegemónicos de la cultura anglosajona a los nativos de las "Banana Republic". 
Artigo original

Hegemonia - Revista Eletrônica do Programa de Mestrado em Direitos Humanos, Cidadania e Violência/Ciência Política do Centro Universitário Unieuro ISSN: $1809-1261$

UNIEURO, Brasília, número 24, Julho a Dezembro de 2018, pp. 110-259.

\section{POSTAL 72}

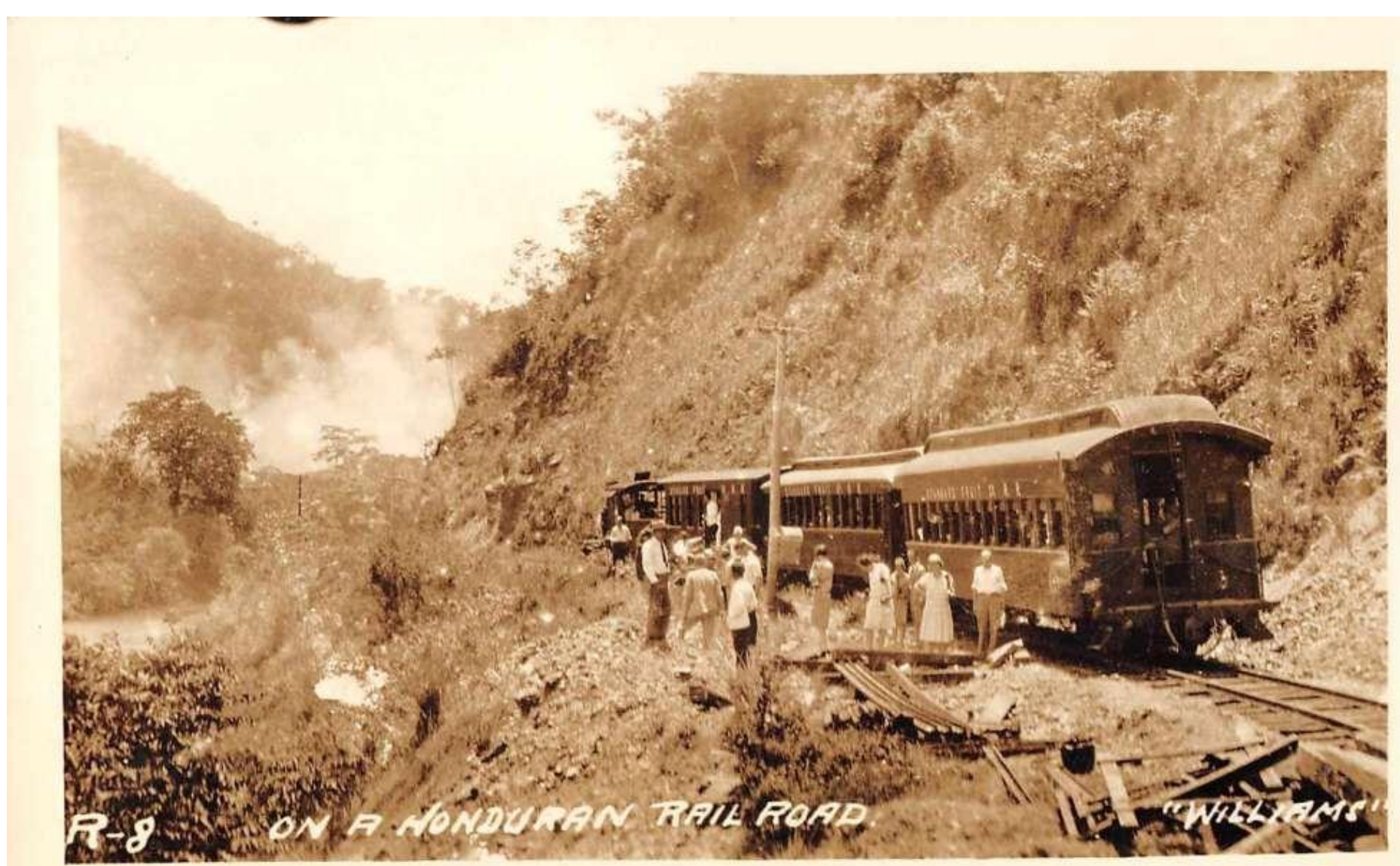

Curiosa y peculiar tarjeta postal de un descarrilamiento de un tren de la "Standard Fruit Company" en las cercanías de La Ceiba, obra del artista fotógrafo Arnold Teodhore Williams. 
Artigo original

Hegemonia - Revista Eletrônica do Programa de Mestrado em Direitos Humanos, Cidadania e Violência/Ciência Política do Centro Universitário Unieuro ISSN: $1809-1261$

UNIEURO, Brasília, número 24, Julho a Dezembro de 2018, pp. 110-259.

\section{POSTAL 73}

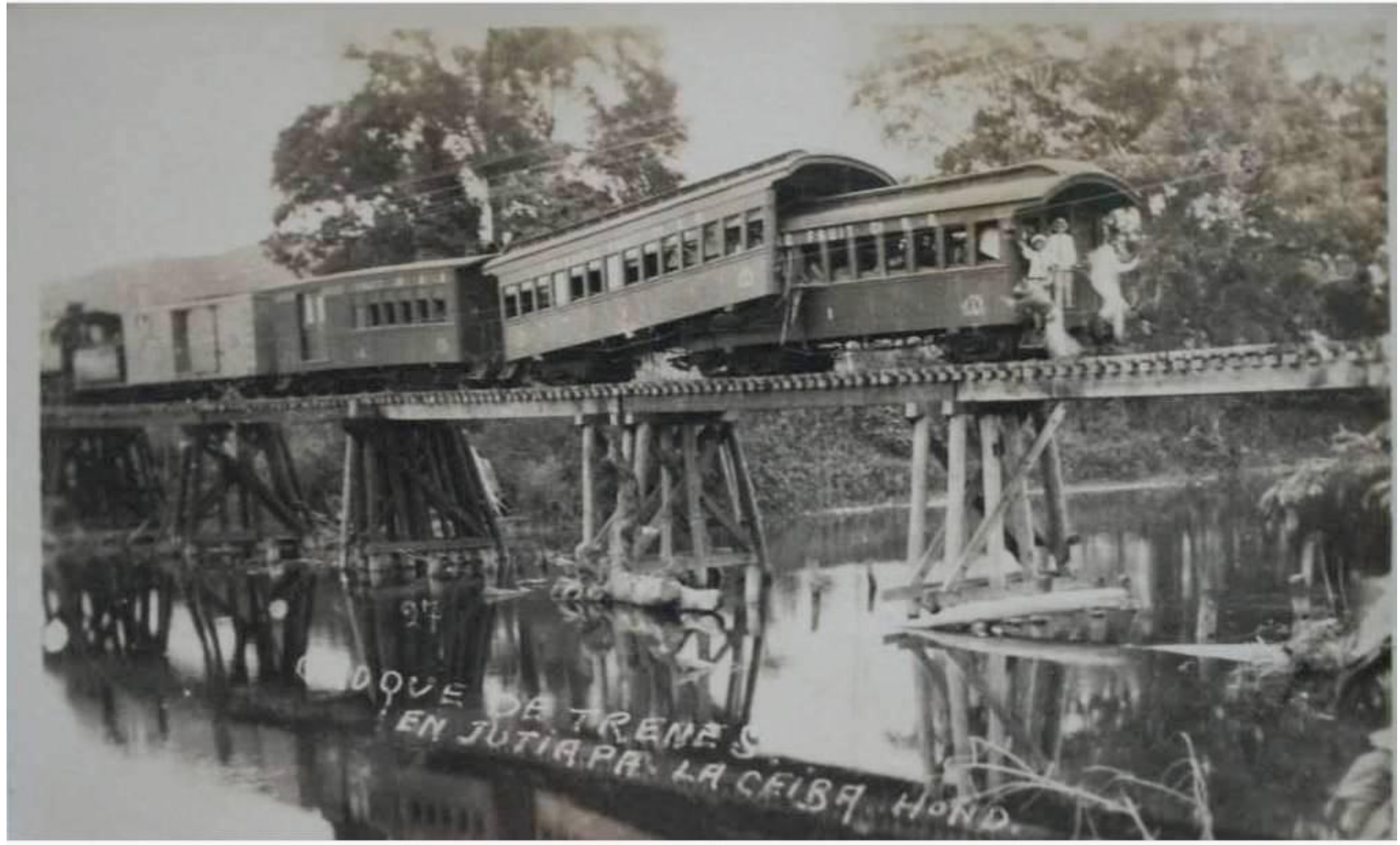

Otra interesante e insólita tarjeta postal titulada "Choque de trenes en Jutiapa, La Ceiba, Hond.", obra del fotógrafo Williams. Este tipo de incidentes, en apariencia cotidianos, llamaban la atención de la población, pues con la llegada de estos artefactos de la Modernidad a las "Banana Republic", asumían que junto al progreso, también llegaban los riesgos de las tecnologías de la época de la Revolución Industrial. 
Artigo original

Hegemonia - Revista Eletrônica do Programa de Mestrado em Direitos Humanos, Cidadania e Violência/Ciência Política do Centro Universitário Unieuro ISSN: 1809-1261

UNIEURO, Brasília, número 24, Julho a Dezembro de 2018, pp. 110-259.

\section{POSTAL 74}

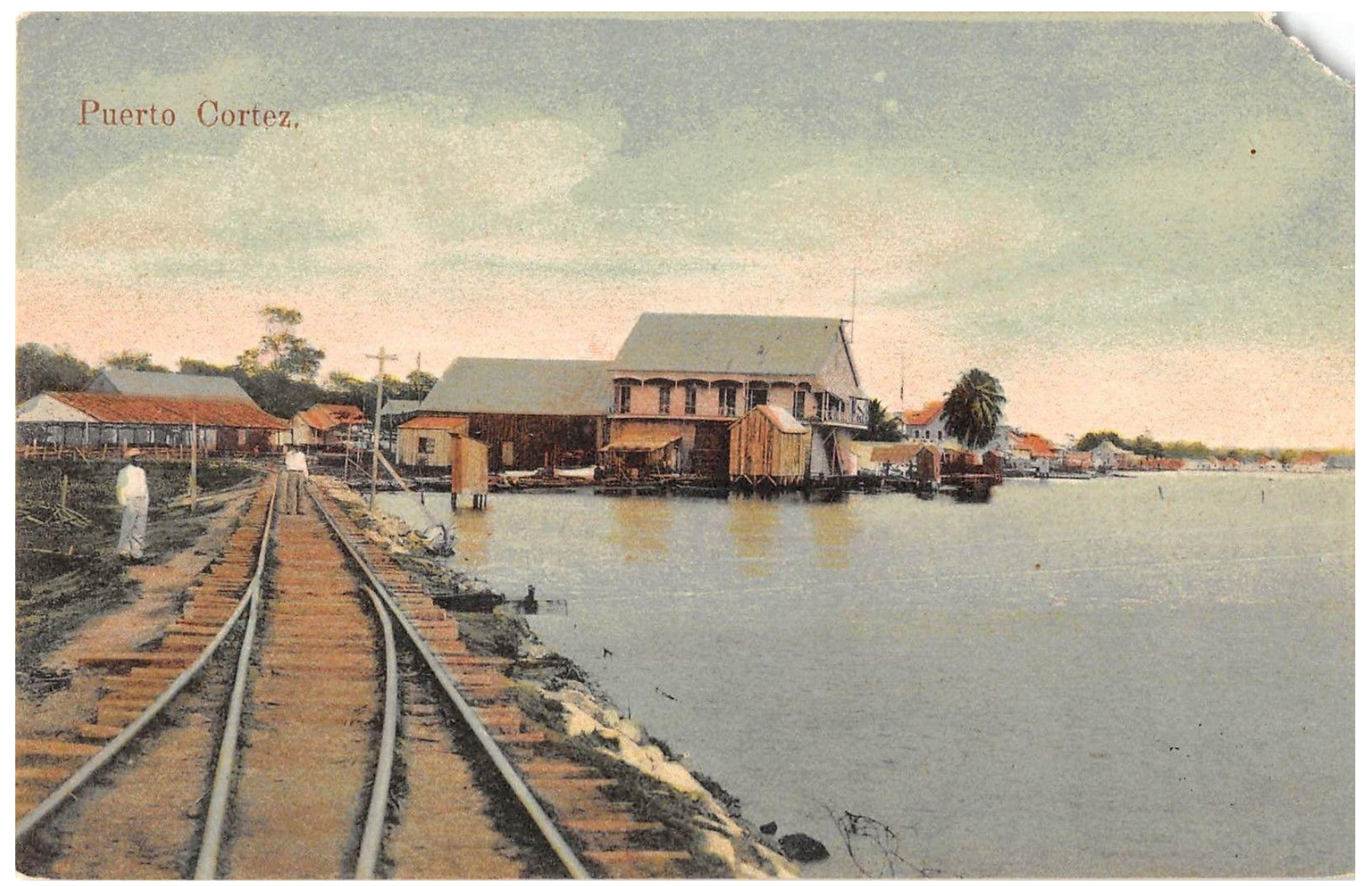

Postal coloreada de Puerto Cortés de 1908, en donde destaca la vía férrea a la par de la bahía y unos parroquianos posando para la cámara. Las postales con escenas de las vías del tren eran de las más difundidas por aquella época, denotando con ello que el ferrocarril se concebía como uno de los más importantes iconos de la llegada de la Modernidad a la "Banana Republic". 
Artigo original

Hegemonia - Revista Eletrônica do Programa de Mestrado em Direitos Humanos, Cidadania e Violência/Ciência Política do Centro Universitário Unieuro ISSN: $1809-1261$

UNIEURO, Brasília, número 24, Julho a Dezembro de 2018, pp. 110-259.

POSTAL 75

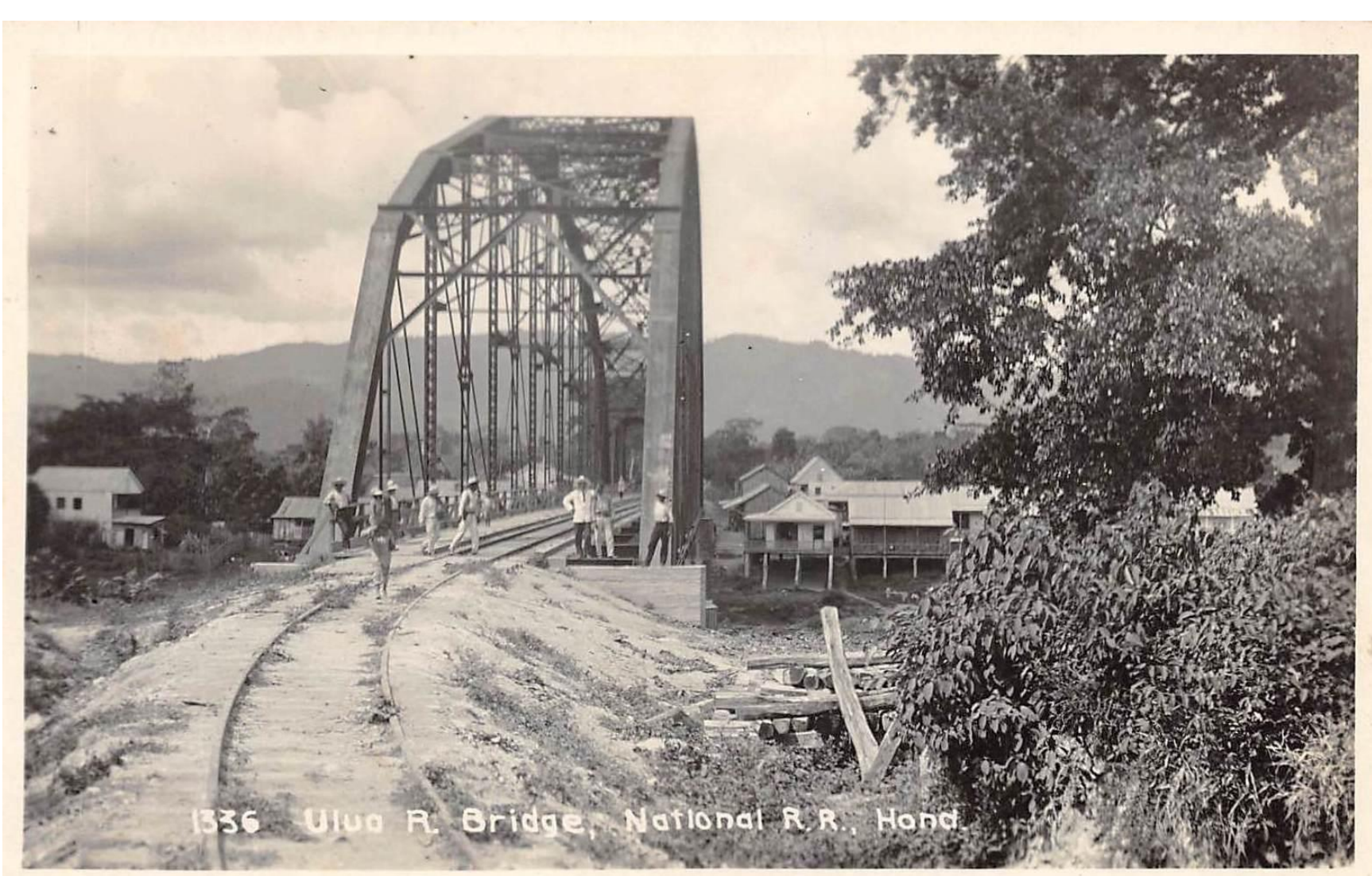

Encantadora tarjeta postal de los años veinte que ilustra el puente de hierro del Río Ulúa, en las cercanías de San Pedro Sula, y a un grupo de trabajadores de las vías en faenas de mantenimiento. La llegada de las compañías bananeras no solamente multiplicó la llegada de estas modernas comunicaciones, sino que también trajo estas nuevas materias primas de la época de la Revolución Industrial, como el uso constante del hierro. 
Artigo original

Hegemonia - Revista Eletrônica do Programa de Mestrado em Direitos Humanos, Cidadania e Violência/Ciência Política do Centro Universitário Unieuro ISSN: 1809-1261

UNIEURO, Brasília, número 24, Julho a Dezembro de 2018, pp. 110-259.

POSTAL 76

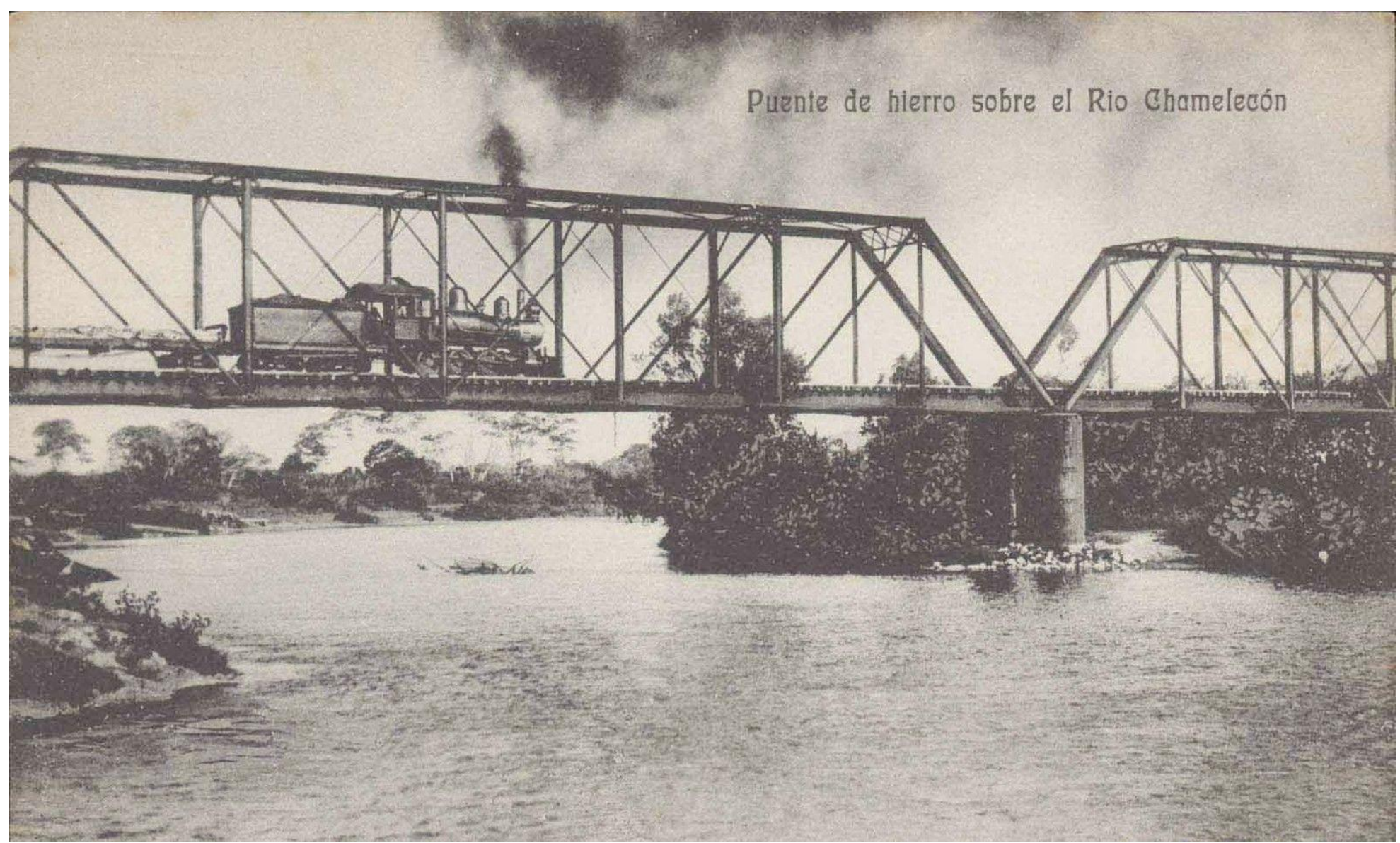

Una de las más bellas estampas de la temática de puentes: el ferrocarril atravesando el hermoso puente de hierro sobre el río Chamelecón, en las cercanías de San Pedro Sula, en esta postal de los años veinte. Estas gigantescas estructuras de hierro eran concebidas como la palpable evidencia de la llegada de la Modernidad a los territorios bananeros. 
Artigo original

Hegemonia - Revista Eletrônica do Programa de Mestrado em Direitos Humanos, Cidadania e Violência/Ciência Política do Centro Universitário Unieuro ISSN: $1809-1261$

UNIEURO, Brasília, número 24, Julho a Dezembro de 2018, pp. 110-259.

POSTAL 77

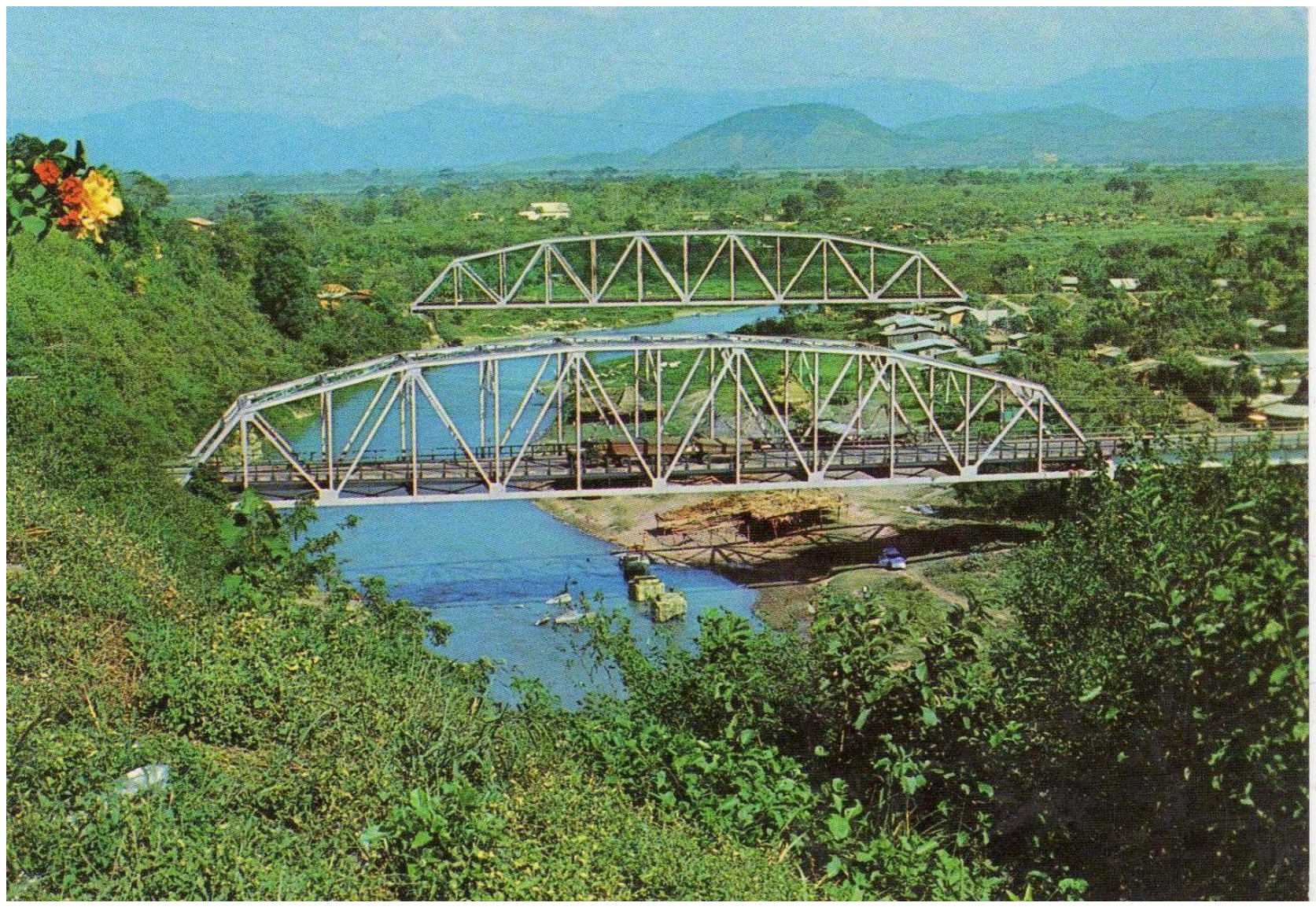

Otra más reciente postal, de la década de los años setenta, donde se aprecia los dos puentes de hierro en las cercanías de la comunidad de Pimienta, en Cortés. Muchos de estos puentes, que aún se conservan, son el testimonio de la memoria heredada de la época de las "Banana Republic" en nuestros países. 


\section{Artigo original}

Hegemonia - Revista Eletrônica do Programa de Mestrado em Direitos Humanos, Cidadania e Violência/Ciência Política do Centro Universitário Unieuro ISSN: 1809-1261

UNIEURO, Brasília, número 24, Julho a Dezembro de 2018, pp. 110-259.

POSTAL 78

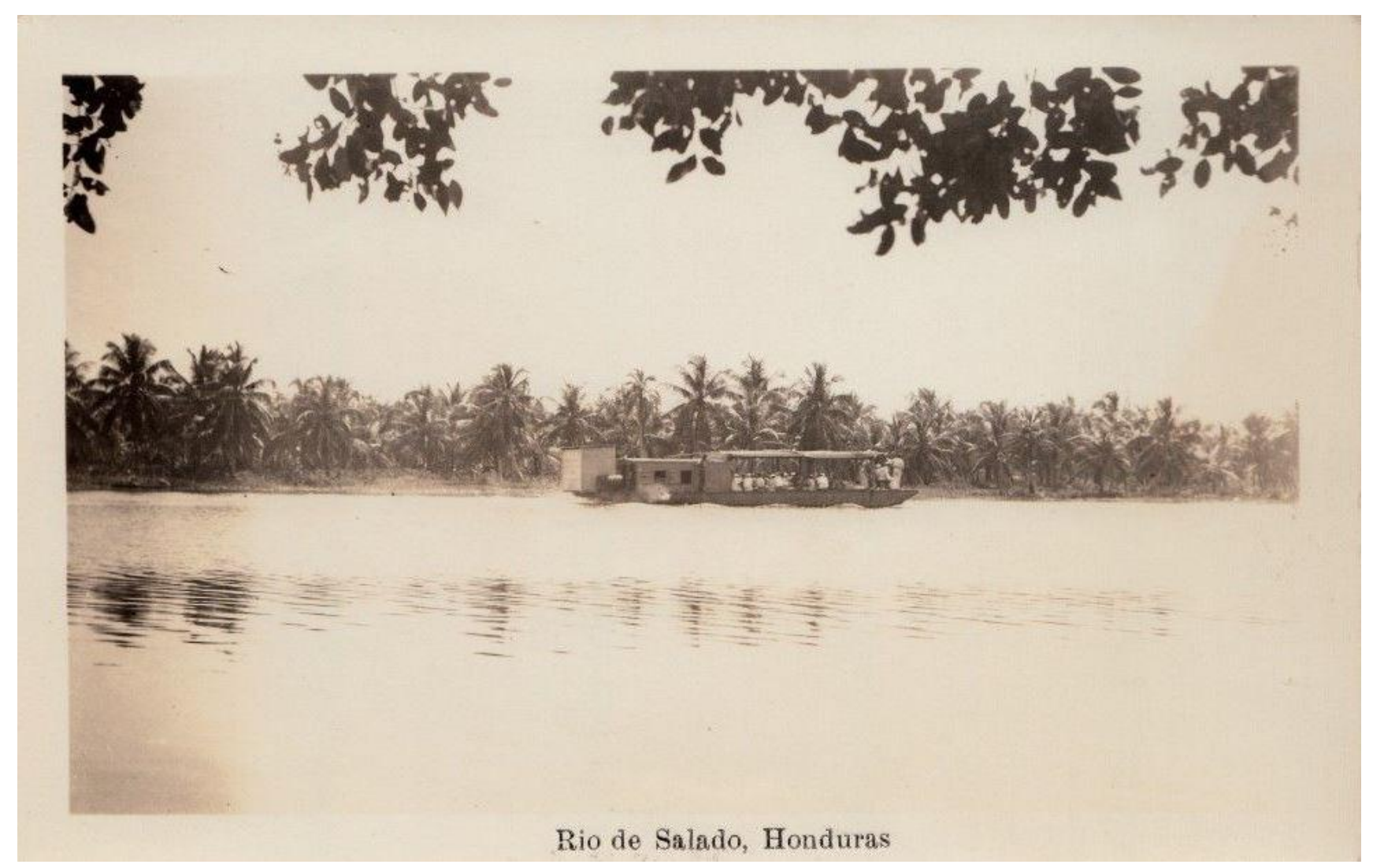

Una barcaza a vapor, cruzando el Río Salado en las cercanías de La Ceiba en los años cuarenta. Junto con los barcos y ferrocarriles, este tipo de transportes a vapor sirvieron para que las compañías bananeras domeñaran el entorno ambiental de la costa norte de Honduras, así como con la intervención de tecnologías como la canalización o drenaje de ríos y sistemas pantanosos, lo cual era una verdadera proeza que demostraba la "victoria" de la Modernidad sobre la "barbarie". 
Artigo original

Hegemonia - Revista Eletrônica do Programa de Mestrado em Direitos Humanos, Cidadania e Violência/Ciência Política do Centro Universitário Unieuro ISSN: $1809-1261$

UNIEURO, Brasília, número 24, Julho a Dezembro de 2018, pp. 110-259.

\section{POSTAL 79}

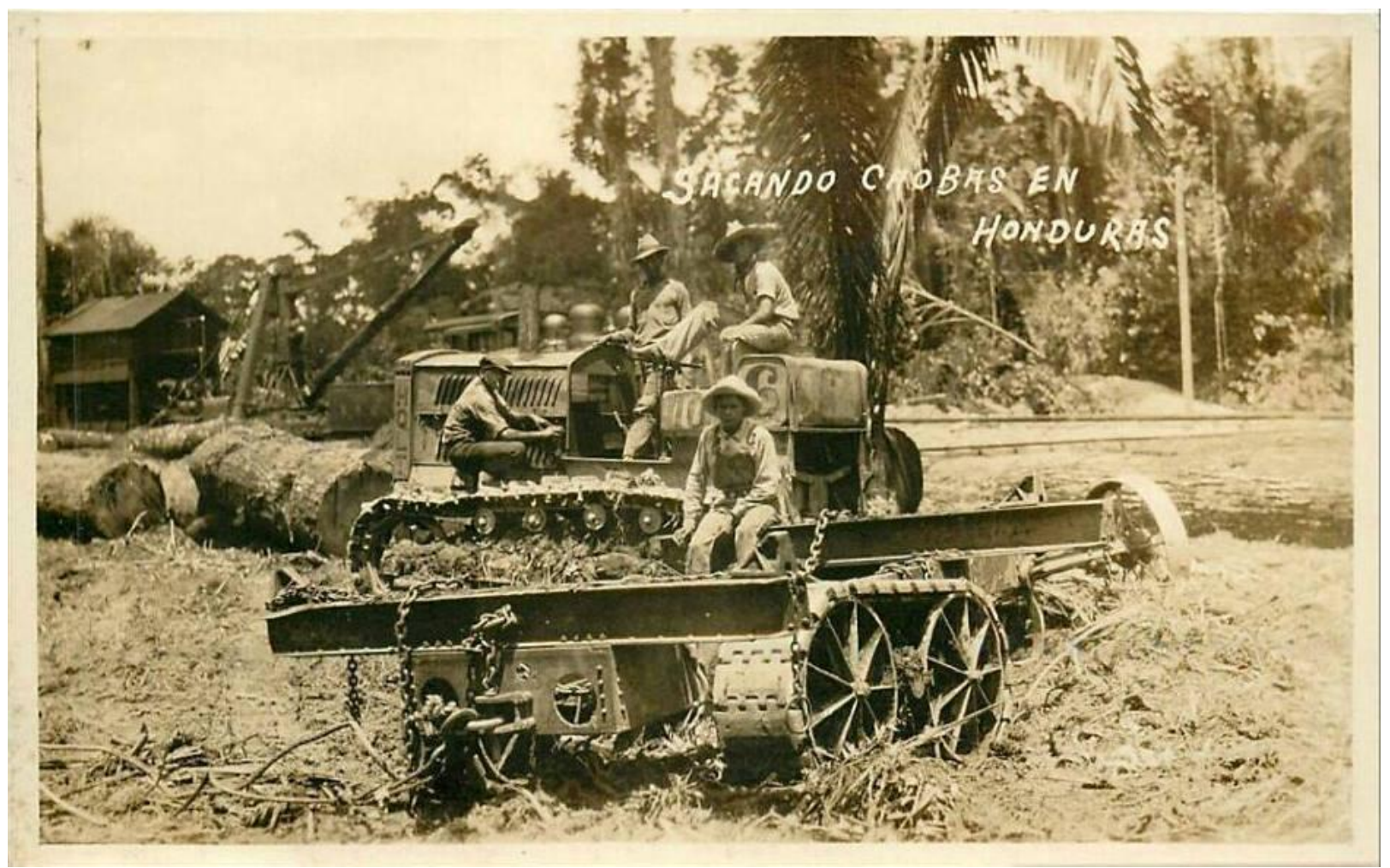

Fantástica postal de 1932, en la que un grupo de trabajadores cortan y cargan enormes trozas de caoba para conducirlas a puerto y exportarlas. En el marco de las generosas concesiones que les daba el Estado, las compañías bananeras no solamente exportaban bananas, sino que también se aprovecharon para usar y exportar gigantescas cantidades de maderas preciosas de la costa norte de nuestro país, maximizando sus ganancias y llevando al límite un modelo económico extractivista que ha modificado y alterado el medio ambiental de toda la costa caribeña hondureña. 
Artigo original

Hegemonia - Revista Eletrônica do Programa de Mestrado em Direitos Humanos, Cidadania e Violência/Ciência Política do Centro Universitário Unieuro ISSN: 1809-1261

UNIEURO, Brasília, número 24, Julho a Dezembro de 2018, pp. 110-259.

\section{POSTAL 80}

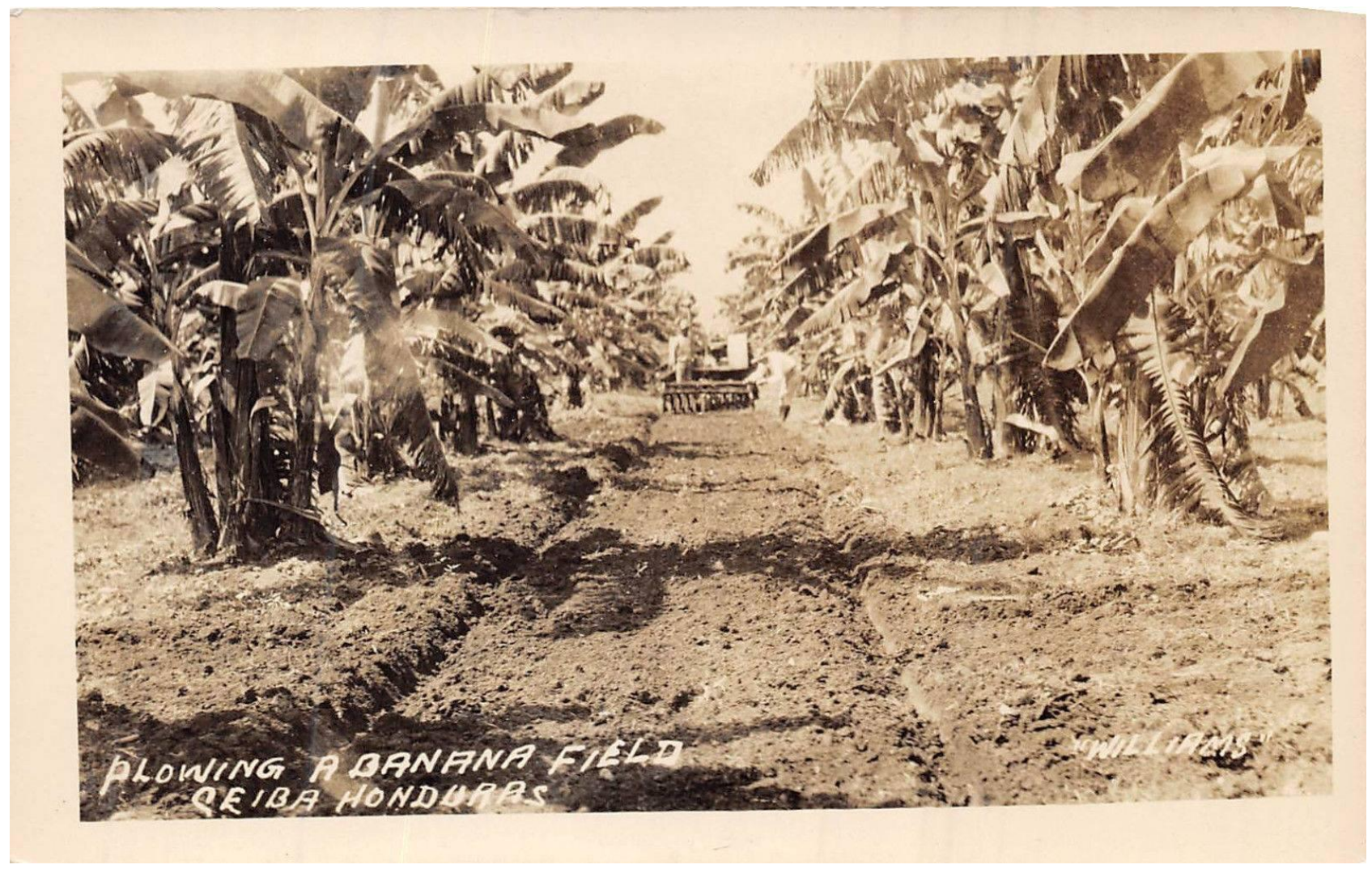

Un tractor arando en un campo bananero en las cercanías de La Ceiba, en esta interesante postal de Arnold Teodhore Williams de 1935. Todas estas tecnologías modernas, como tractores, barcos, ferrocarriles, canales, sistemas de fumigación con químicos, etcétera, fueron factores que contribuyeron al éxito de las compañías bananeras e hicieron ver que estas empresas imponían la Modernidad en las "Banana Republic". 


\section{Artigo original}

Hegemonia - Revista Eletrônica do Programa de Mestrado em Direitos Humanos, Cidadania e Violência/Ciência Política do Centro Universitário Unieuro ISSN: $1809-1261$

UNIEURO, Brasília, número 24, Julho a Dezembro de 2018, pp. 110-259.

\section{POSTAL 81}

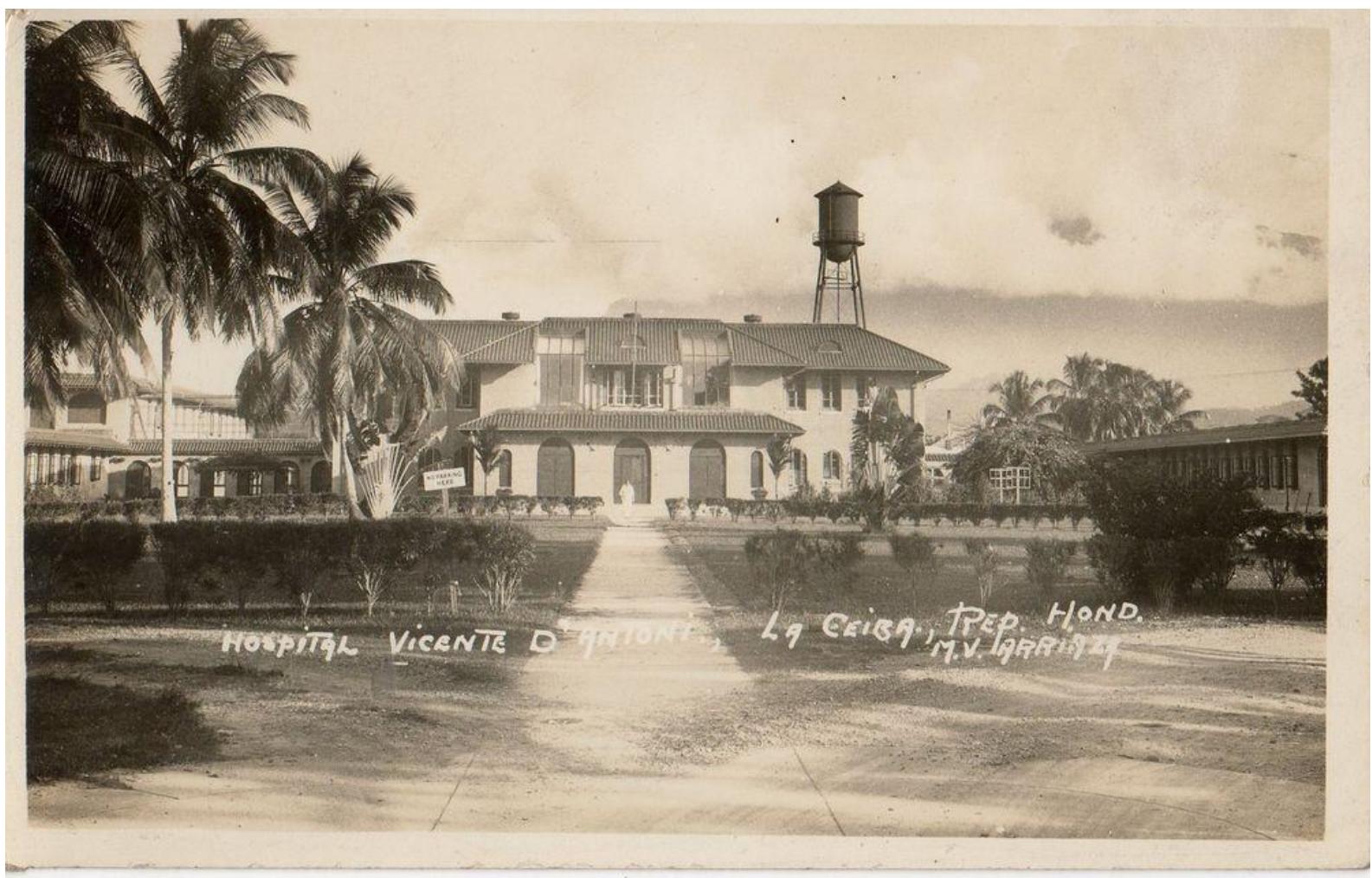

Fantástica postal de los años treinta, del moderno "Hospital Vicente D’Antony" de La Ceiba, Atlántida, construido por la "Standard Fruit Company", posiblemente uno de los primeros hospitales modernos que se instalaron en Honduras. Este tipo de nuevos servicios sanitarios brindados por estos centros hospitalarios también denotaban la llegada de la Modernidad, pues estaban instalados con las tecnologías modernas y médicos profesionales. 


\section{Artigo original}

Hegemonia - Revista Eletrônica do Programa de Mestrado em Direitos Humanos, Cidadania e Violência/Ciência Política do Centro Universitário Unieuro ISSN: 1809-1261

UNIEURO, Brasília, número 24, Julho a Dezembro de 2018, pp. 110-259.

\section{POSTAL 82}

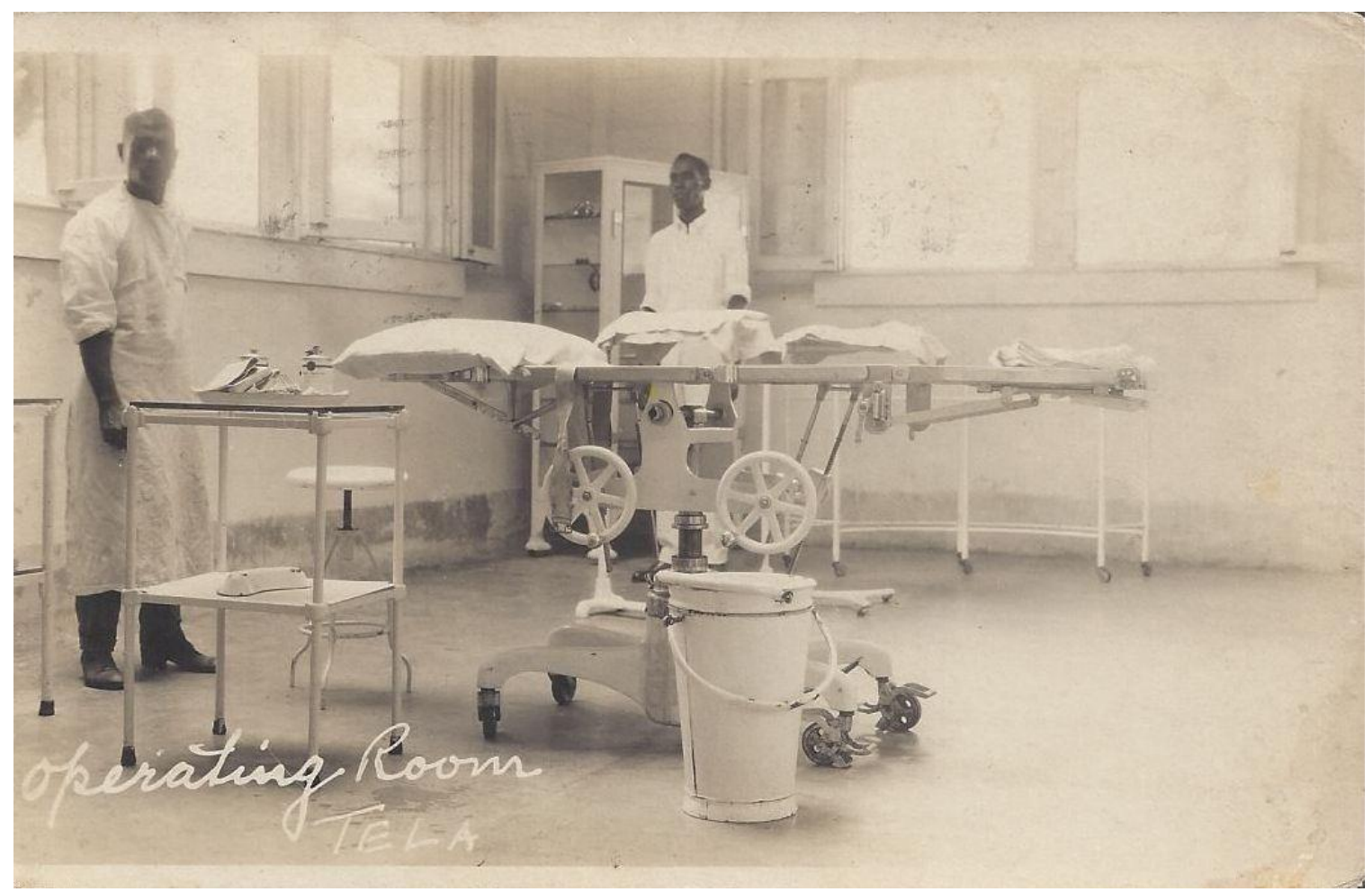

Extraordinaria tarjeta postal de 1924, que muestra la "Sala de Operaciones" del "Hospital de Tela", propiedad de la "Tela Railroad Company". La estampa elocuencia las tecnologías y aparatos modernos de estos centros sanitarios de la compañía. Sin embargo, casi todos los estudios críticos evidencian que estos espacios en realidad eran para los servicios de salud de los funcionarios gringos y hondureños; los campeños eran atendidos en dispensarios médicos instalados en las fincas bananeras, casi siempre deficientes y escasos de medicinas como los del Estado hondureño. Fue hasta la gran huelga de 1954 que estos empezaron a mejorarse. 
Artigo original

Hegemonia - Revista Eletrônica do Programa de Mestrado em Direitos Humanos, Cidadania e Violência/Ciência Política do Centro Universitário Unieuro ISSN: $1809-1261$

UNIEURO, Brasília, número 24, Julho a Dezembro de 2018, pp. 110-259.

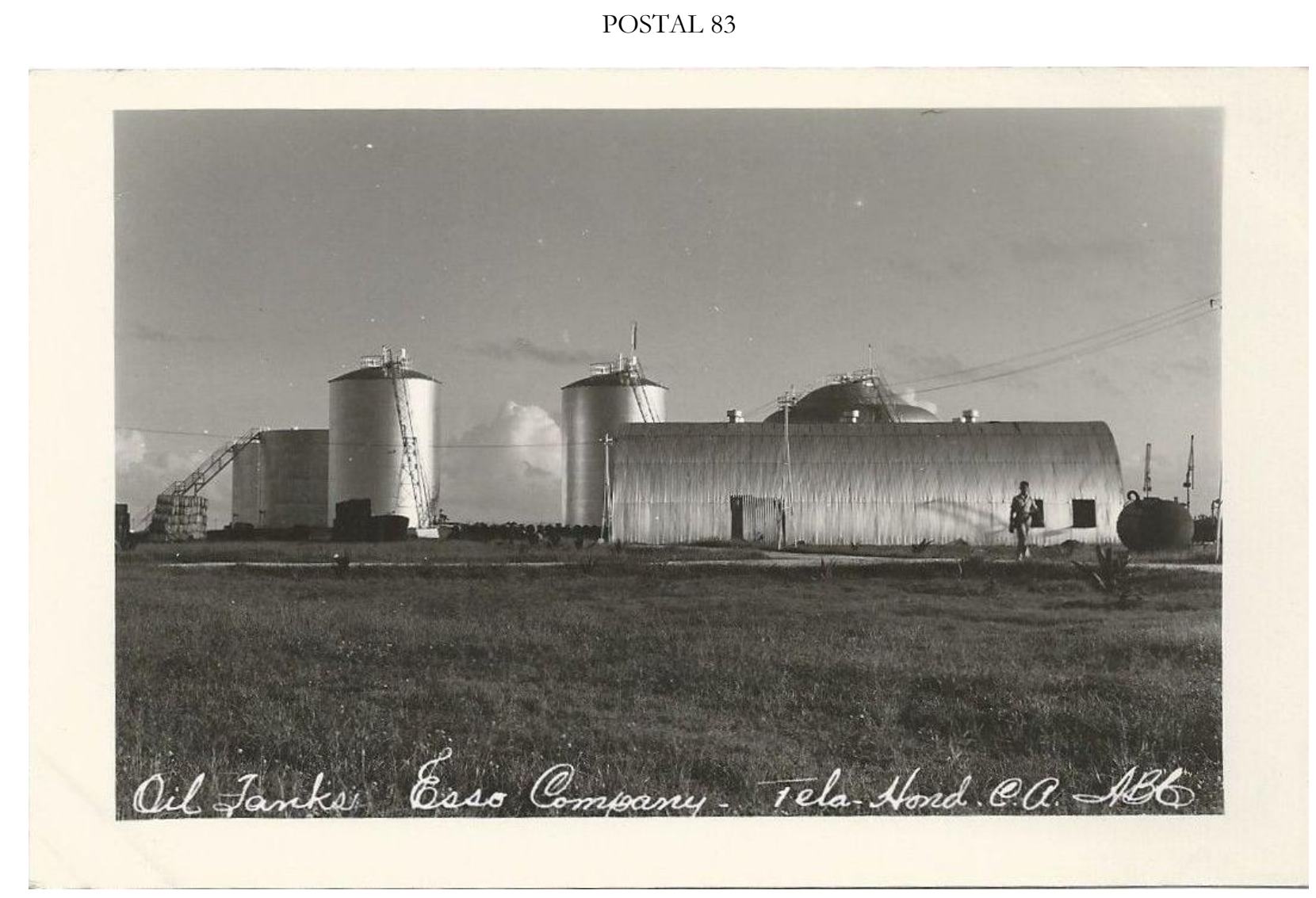

Postal de los tanques de combustible de la "Tela Railroad Company" en la ciudad de Tela, Atlántida, que como expresa la estampa, eran abastecidos por la "Esso Company". La llegada de estas transnacionales articuló los intereses de muchos magnates norteamericanos, pues el mismo J. P. Morgan estuvo vinculado con varias de estas empresas que terminaron apoderándose de los más importantes recursos de estas "Banana Republic". 


\section{Artigo original}

Hegemonia - Revista Eletrônica do Programa de Mestrado em Direitos Humanos, Cidadania e Violência/Ciência Política do Centro Universitário Unieuro ISSN: 1809-1261

UNIEURO, Brasília, número 24, Julho a Dezembro de 2018, pp. 110-259.

\section{POSTAL 84}

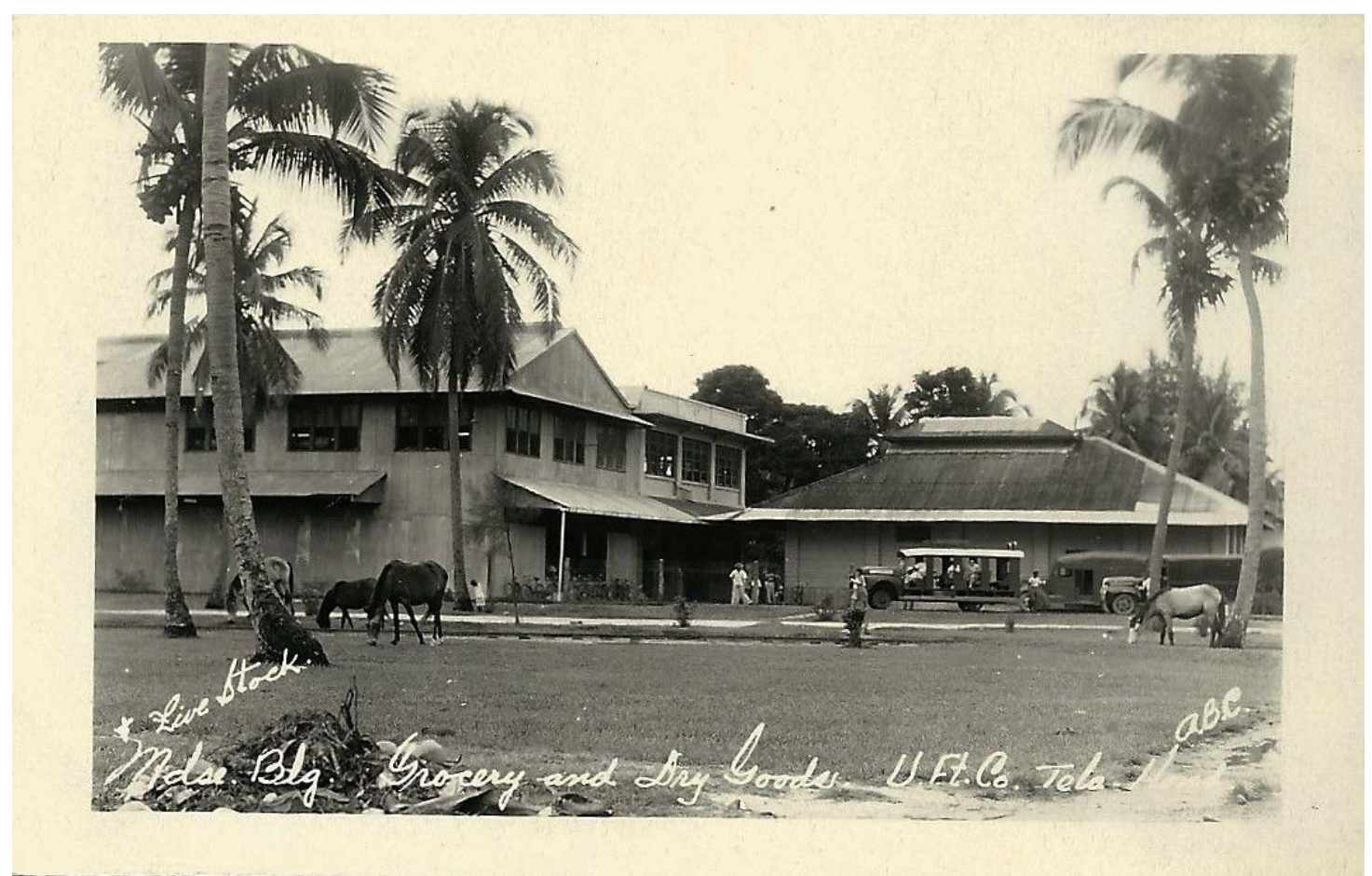

Postal de los años treinta de las instalaciones del "Comisariato" o "Tienda de Raya" de la "Tela Railroad Company", subsidiaria de la "United Fruit Company". Los Comisariatos fueron importantes centros de importación de los artefactos y artículos de consumo de la "Modernidad", pues traían de venta productos enlatados (conservas, sardinas, mermeladas), alimentos anglosajones (Corn Flakes, Oat Meals) radios, ropa, etcétera, pero también, fueron centros de competencia comercial desleal, pues ofrecían sus productos a cambio de "cupones de venta", lo cual fue contraproducente para el comercio local que era controlado por comerciantes palestinos, chinos, salvadoreños y hondureños. 
Artigo original

Hegemonia - Revista Eletrônica do Programa de Mestrado em Direitos Humanos, Cidadania e Violência/Ciência Política do Centro Universitário Unieuro ISSN: $1809-1261$

UNIEURO, Brasília, número 24, Julho a Dezembro de 2018, pp. 110-259.

POSTAL 85

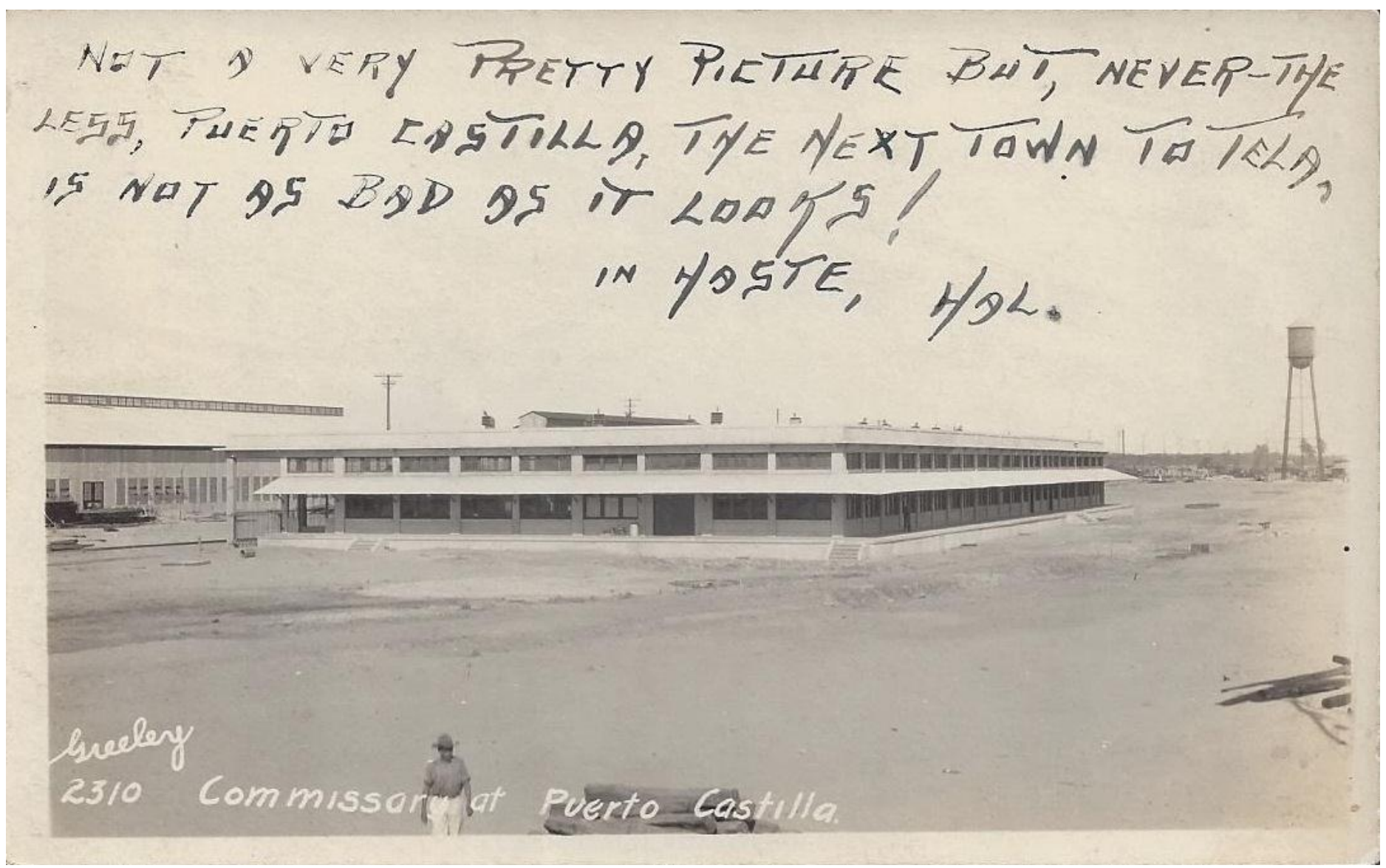

Estampa de los años cuarenta del moderno edificio del "Comisariato" de la "Truxillo Railroad Company", subsidiaria de la "United Fruit Company" en Puerto Castilla, departamento de Colón. 
Artigo original

Hegemonia - Revista Eletrônica do Programa de Mestrado em Direitos Humanos, Cidadania e Violência/Ciência Política do Centro Universitário Unieuro ISSN: $1809-1261$

UNIEURO, Brasília, número 24, Julho a Dezembro de 2018, pp. 110-259.

POSTAL 86

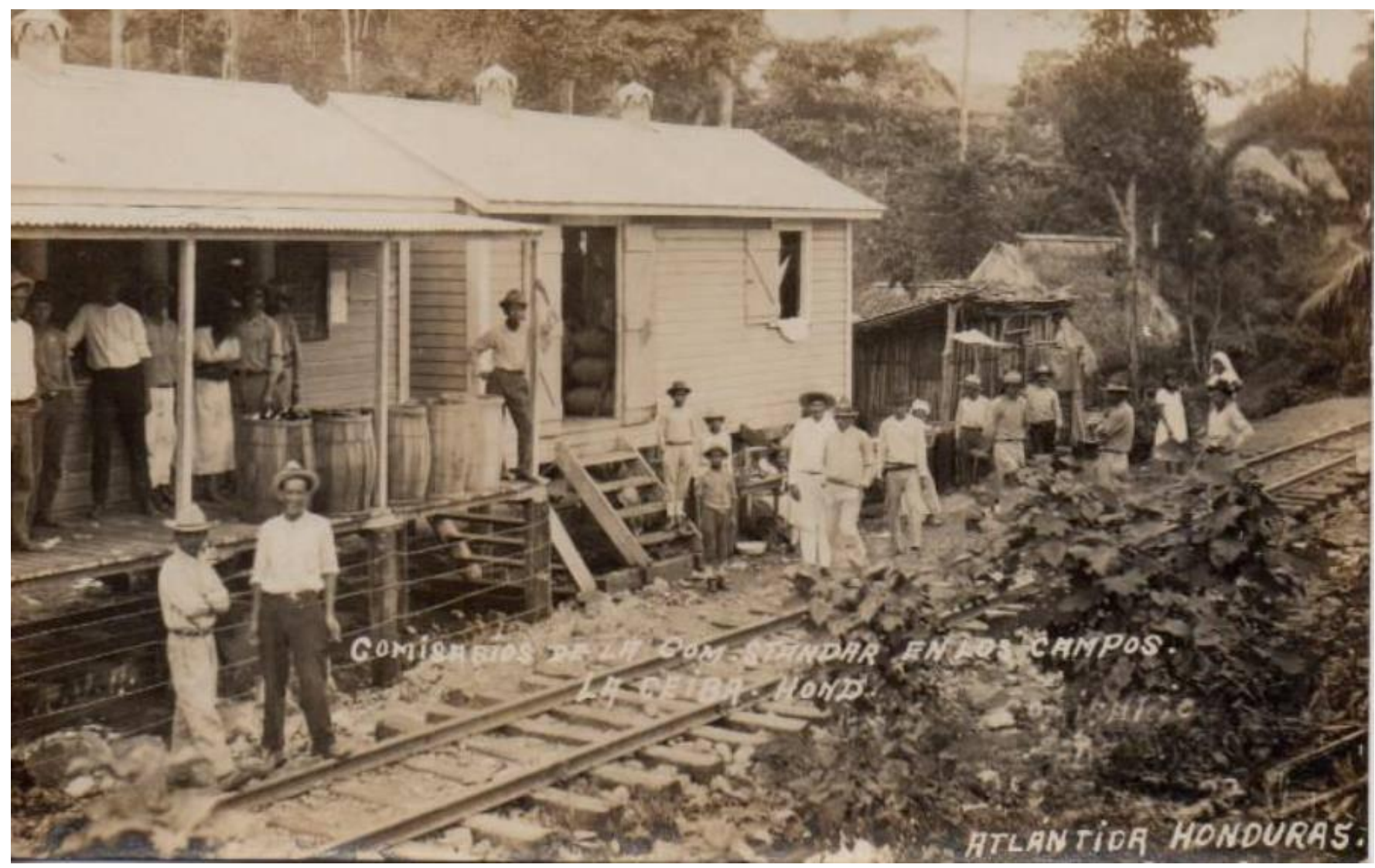

Un pequeño "Comisariato" de una finca bananera cercana a La Ceiba, Atlántida, cuya infraestructura se ve mucho más simple y humilde en comparación a los que estaban ubicados en los centros urbanos como Tela o Trujillo, en esta tarjeta postal de Arnold Teodhore Williams de los años cuarenta. 
Artigo original

Hegemonia - Revista Eletrônica do Programa de Mestrado em Direitos Humanos, Cidadania e Violência/Ciência Política do Centro Universitário Unieuro ISSN: 1809-1261

UNIEURO, Brasília, número 24, Julho a Dezembro de 2018, pp. 110-259.

\section{Postal 87}

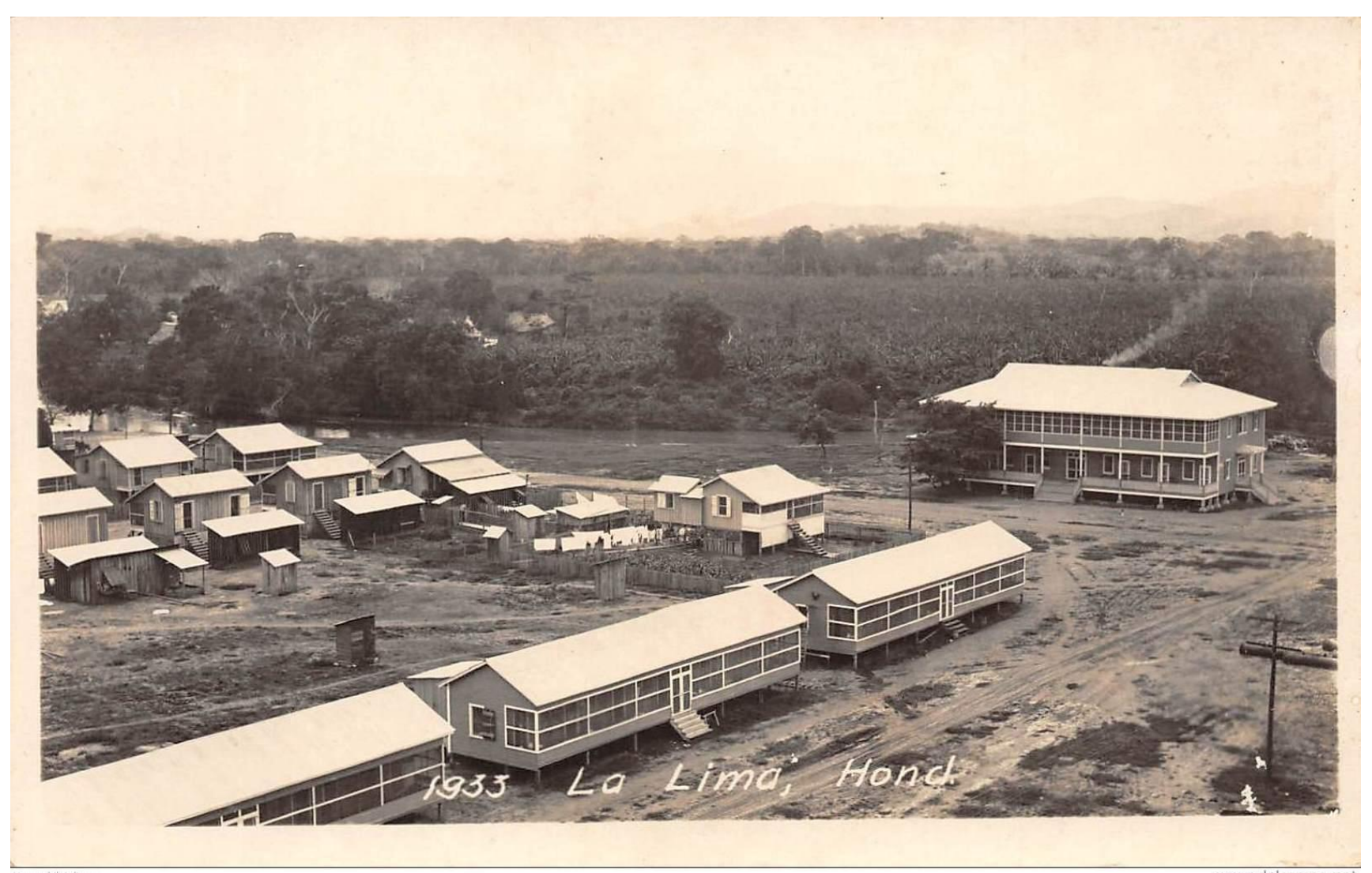

Postal panorámica de una finca bananera del distrito de La Lima, Cortés, donde se aprecian los barracones que alojaban a las familias de los campeños, y al extremo derecho el edificio de oficinas de los empleados intermedios que dirigían las labores en la finca. Como se aprecia, los barracones eran apenas construcciones de madera, muy distintas de las elegantes y confortables viviendas de los altos funcionarios, que imitaban la arquitectura de las residencias y mansiones del sur de los Estados

Unidos. 
Artigo original

Hegemonia - Revista Eletrônica do Programa de Mestrado em Direitos Humanos, Cidadania e Violência/Ciência Política do Centro Universitário Unieuro ISSN: $1809-1261$

UNIEURO, Brasília, número 24, Julho a Dezembro de 2018, pp. 110-259.

POSTAL 88

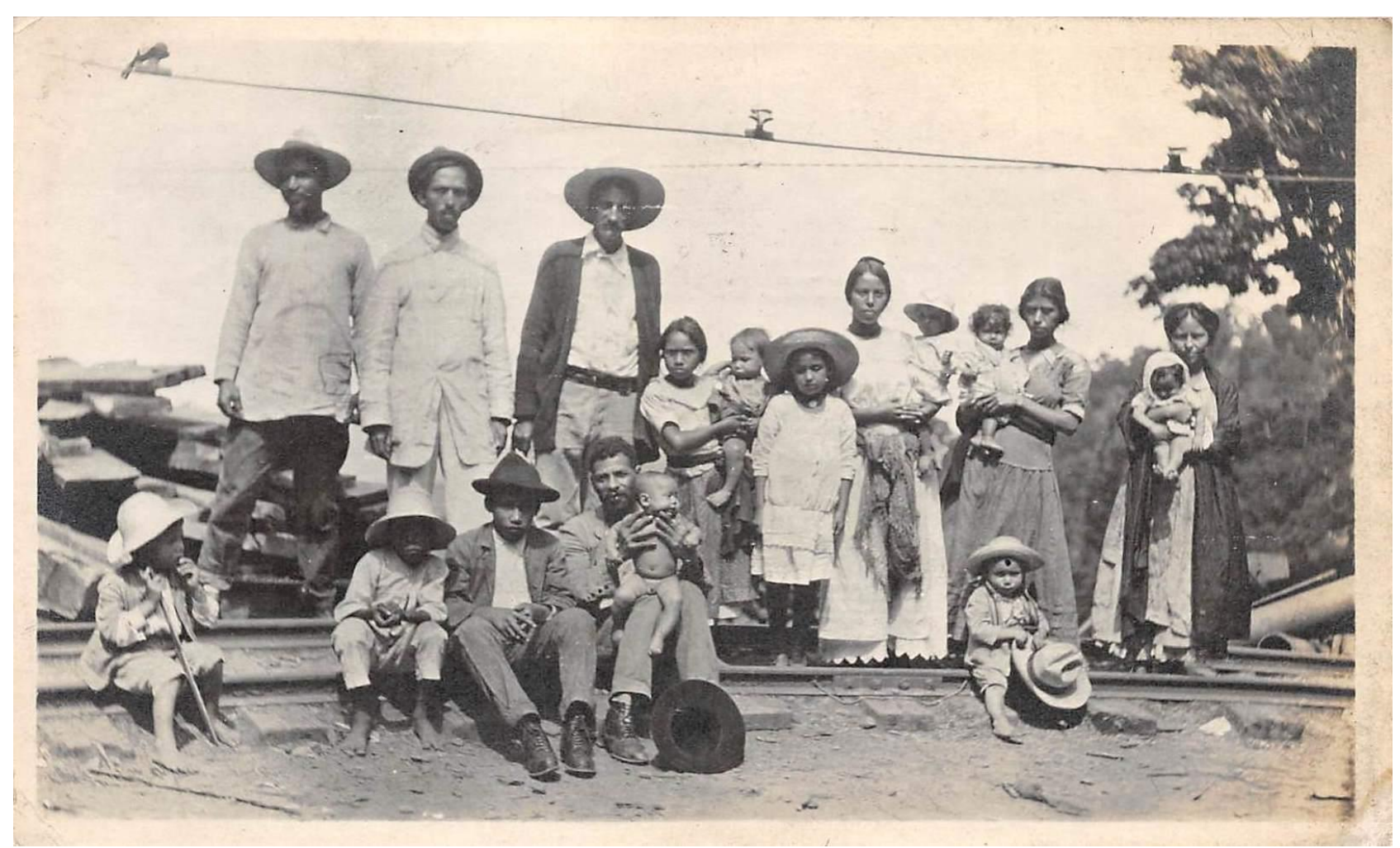

Hermosa postal de los años veinte que ilustra a una familia campeña posando junto a los rieles del ferrocarril. La mayoría de estas familias emigraron desde muchas partes del interior de Honduras, especialmente del Sur, de Olancho y del Occidente del país, así como de otros países de la región, especialmente El Salvador. Con ellos llevaron costumbres y tradiciones de sus comarcas, pero también aprendieron la cultura impuesta por los norteamericanos en la "Banana Republic". 
Artigo original

Hegemonia - Revista Eletrônica do Programa de Mestrado em Direitos Humanos, Cidadania e Violência/Ciência Política do Centro Universitário Unieuro ISSN: $1809-1261$

UNIEURO, Brasília, número 24, Julho a Dezembro de 2018, pp. 110-259.

POSTAL 89

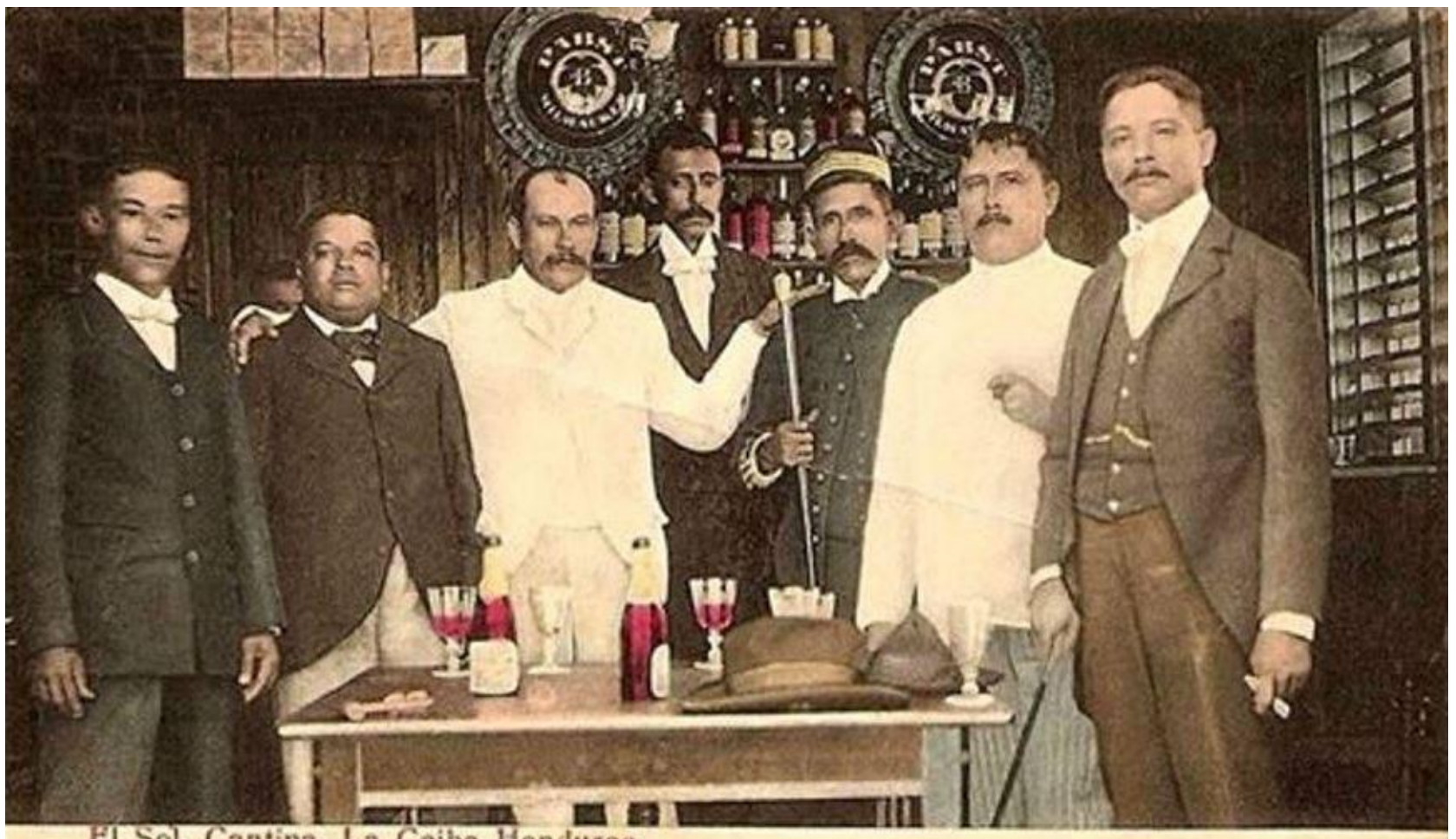

El Sol. Cantina, La Ceiba Honduras

Un dia de fiesta nacional.

Bazar It.stiano, La Cella (tlosdurax)

Curiosa tarjeta postal editada por "Bazar Italiano" de La Ceiba, que ilustra a un grupo de personajes de la clase alta de la ciudad, posiblemente ligados en negocios con la compañía bananera, departiendo en un bar que ofrece bebidas importadas como vinos y cogñac. Su vestimenta también delata que es importada de Inglaterra o Estados Unidos. Todos estos detalles ilustran la adopción de las modas y costumbres de la "Belle Epoque" y de la Modernidad en estos lares de la "Banana Republic". 


\section{Artigo original}

Hegemonia - Revista Eletrônica do Programa de Mestrado em Direitos Humanos, Cidadania e Violência/Ciência Política do Centro Universitário Unieuro ISSN: 1809-1261

UNIEURO, Brasília, número 24, Julho a Dezembro de 2018, pp. 110-259.

\section{POSTAL 90}

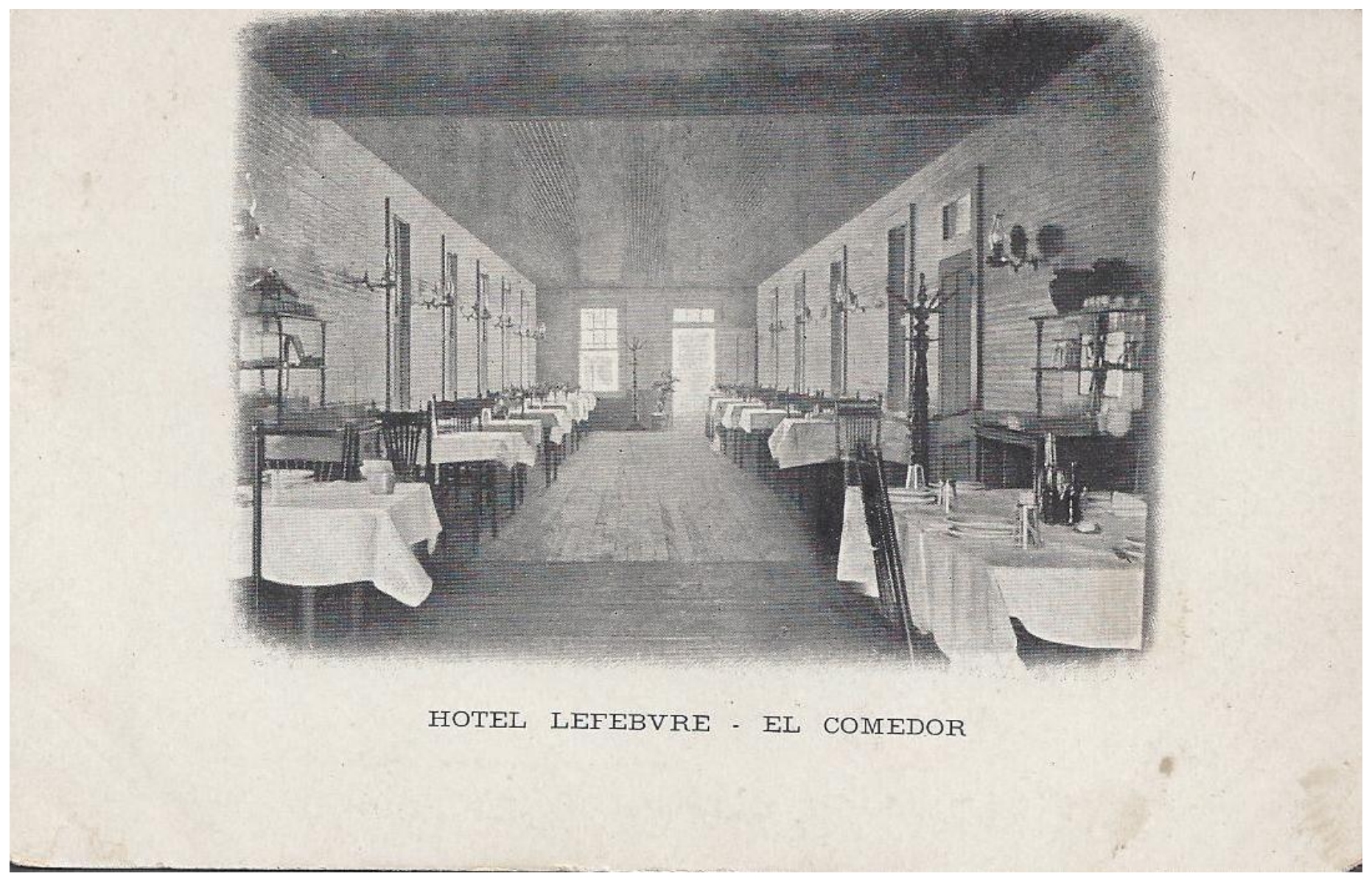

Postal de 1908 del interior del "Hotel Lefebvre" de Puerto Cortés. Se aprecia el servicio de restaurante y el orden acostumbrado en este tipo de negocios. Este tipo de negocios como hoteles, restaurantes, bares, cafés y demás, eran evidencia de la expansión urbana y de la Modernidad que arribana con las compañías bananeras. 
Artigo original

Hegemonia - Revista Eletrônica do Programa de Mestrado em Direitos Humanos, Cidadania e Violência/Ciência Política do Centro Universitário Unieuro ISSN: 1809-1261

UNIEURO, Brasília, número 24, Julho a Dezembro de 2018, pp. 110-259.

\section{POSTAL 91}

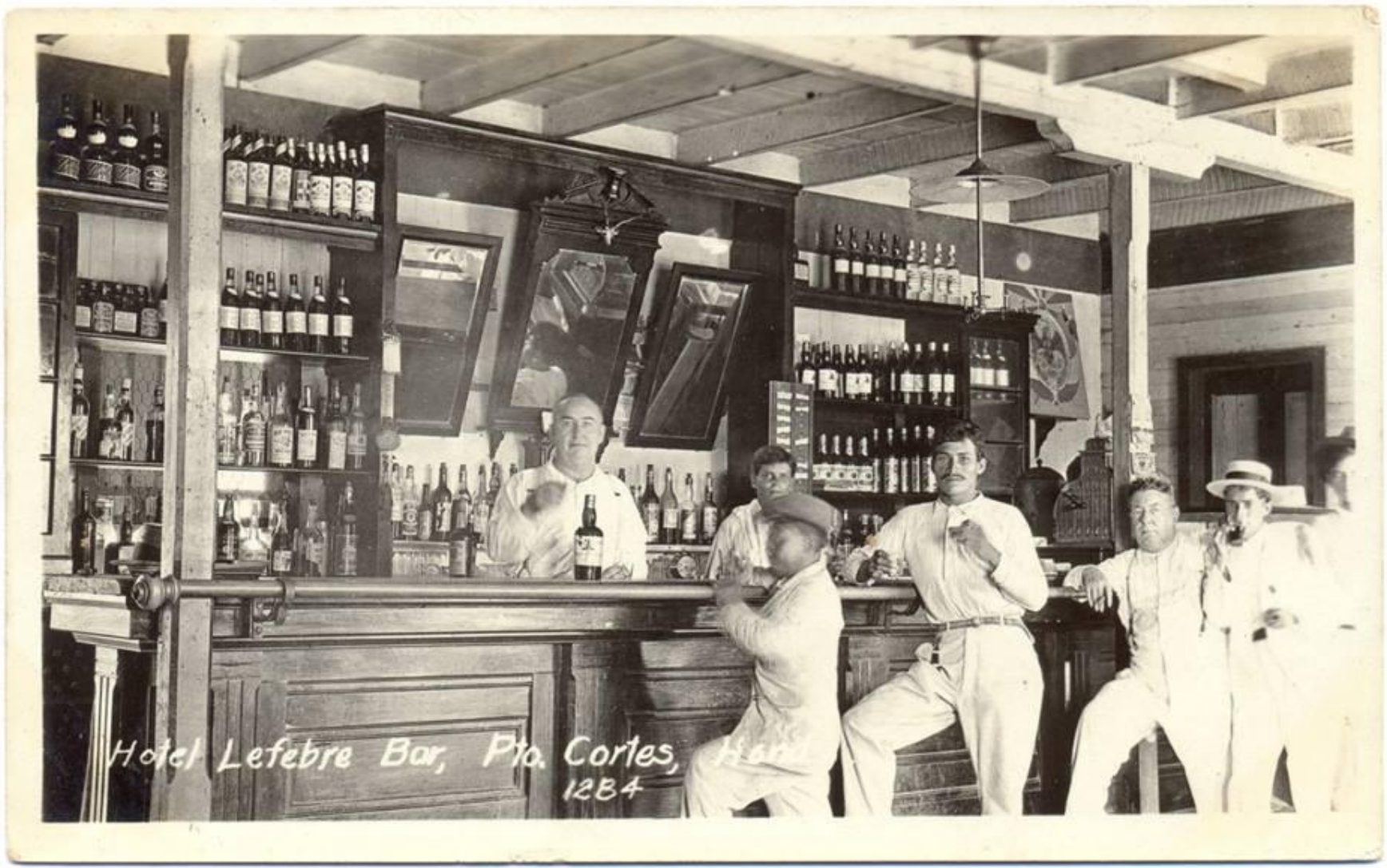

Extraordinaria tarjeta postal del Bar del "Hotel Lefebvre" de Puerto Cortés. La barra se ve repleta de gaseosas, vinos y licores importados de Europa y Estados Unidos, en el centro, el "Barman" prepara unos tragos, y en primera fila, los clientes posan ufanos tomando sus copas. Todas estas nuevas prácticas culturales evidenciaban nuevas formas de sociabilidad que eran inherentes a la Modernidad. 
Artigo original

Hegemonia - Revista Eletrônica do Programa de Mestrado em Direitos Humanos, Cidadania e Violência/Ciência Política do Centro Universitário Unieuro ISSN: 1809-1261

UNIEURO, Brasília, número 24, Julho a Dezembro de 2018, pp. 110-259.

POSTAL 92

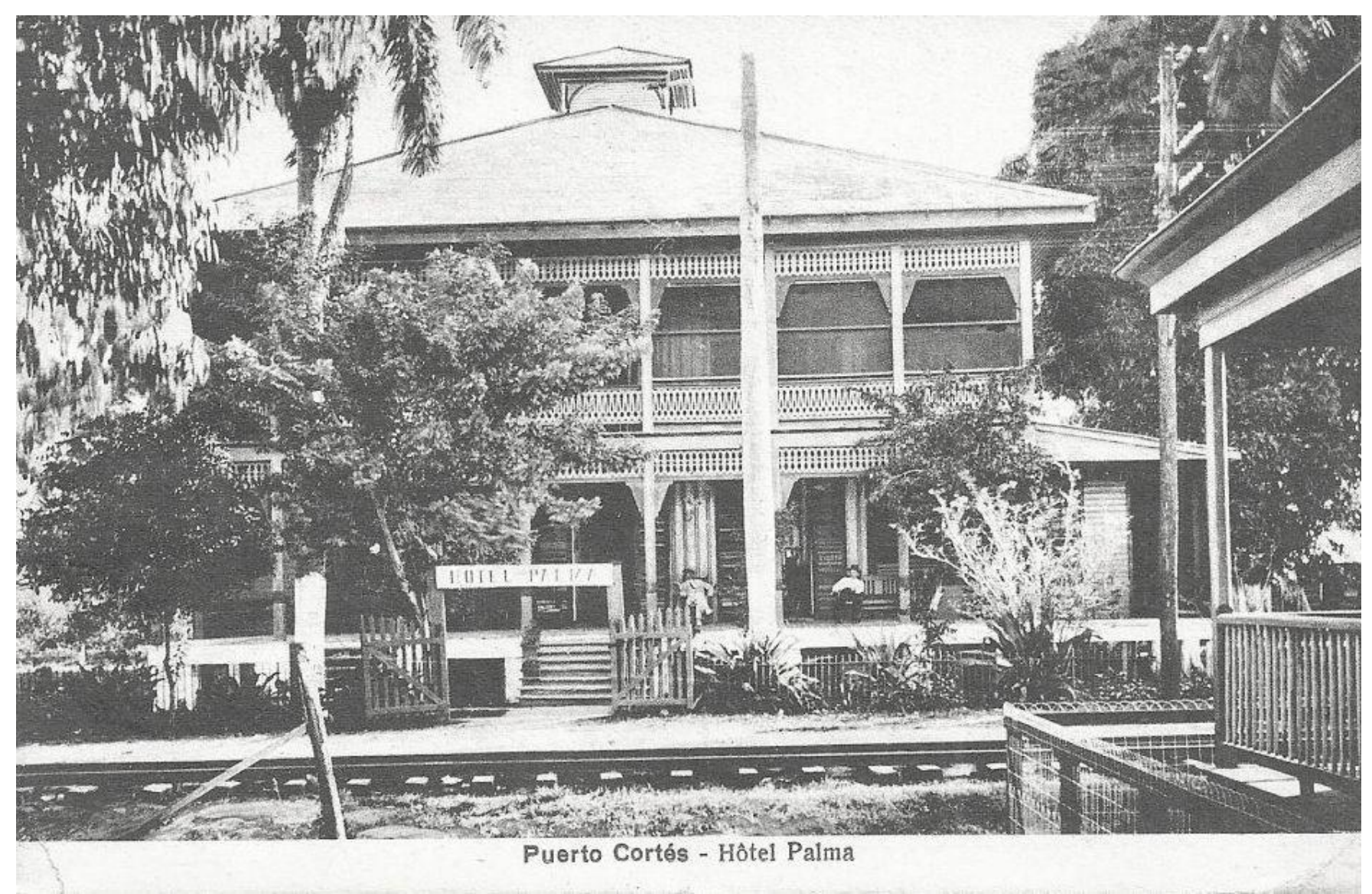

Tarjeta postal del "Hotel Palma" de Puerto Cortés, que muestra a un edificio elegante, de estilo de la arquitectura victoriana del sur de los Estados Unidos, y en primer plano, el dueño del negocio posa en el corredor con algún amigo. 
Artigo original

Hegemonia - Revista Eletrônica do Programa de Mestrado em Direitos Humanos, Cidadania e Violência/Ciência Política do Centro Universitário Unieuro ISSN: $1809-1261$

UNIEURO, Brasília, número 24, Julho a Dezembro de 2018, pp. 110-259.

POSTAL 93

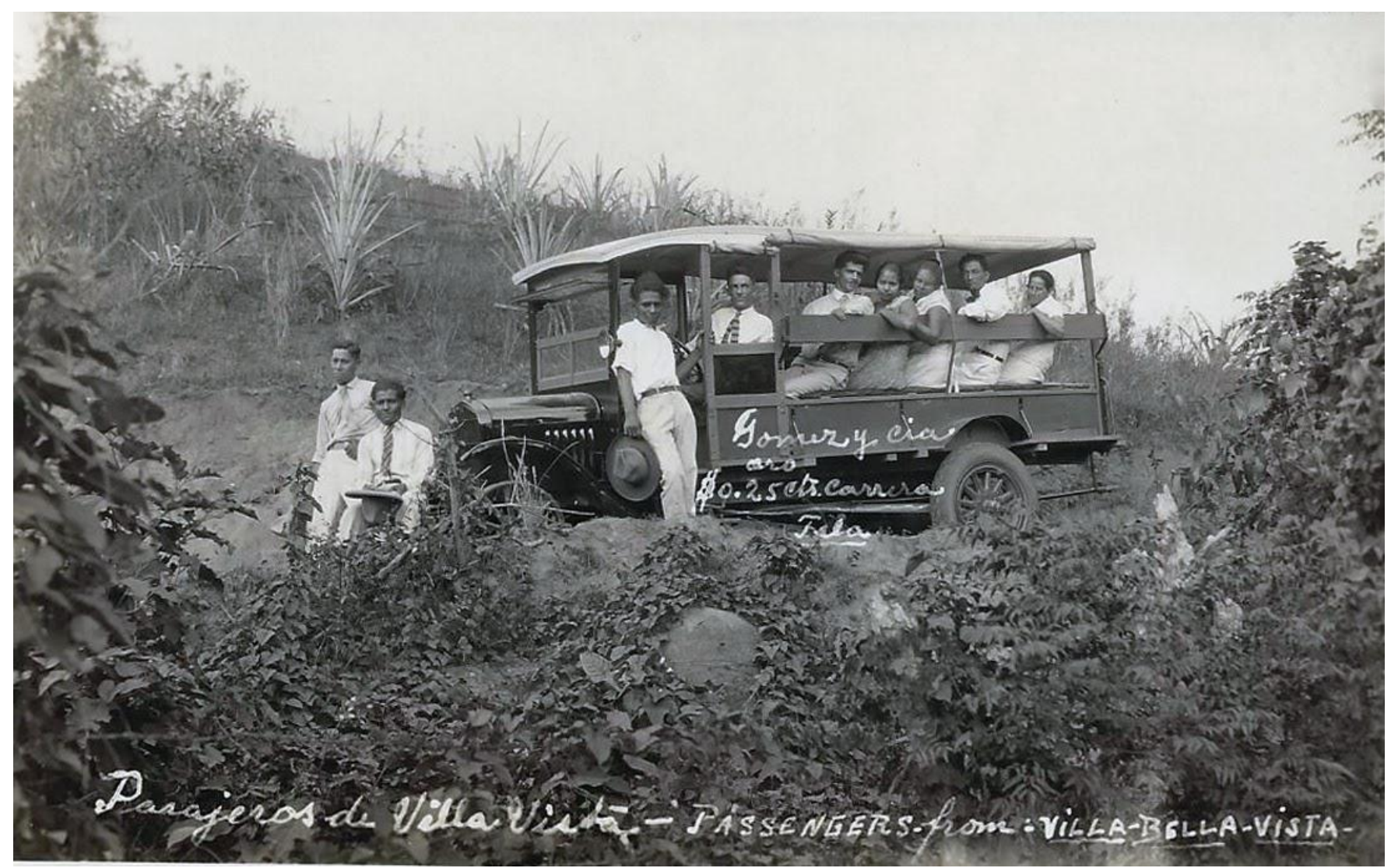

Fantástica tarjeta postal de una "Baronesa" o "Bus popular", estacionada en el camino entre Tela y Bella Vista, en 1924. Además del ferrocarril y los barcos, los buses y automóviles fueron incrementando el parque vehicular del país a lo largo del siglo XX, y con ello el crecimiento de infraestructuras carreteras que fueron uniendo poco a poco el país, y con ello coadyuvando a la integración nacional. 
Artigo original

Hegemonia - Revista Eletrônica do Programa de Mestrado em Direitos Humanos, Cidadania e Violência/Ciência Política do Centro Universitário Unieuro ISSN: 1809-1261

UNIEURO, Brasília, número 24, Julho a Dezembro de 2018, pp. 110-259.

\section{POSTAL 94}

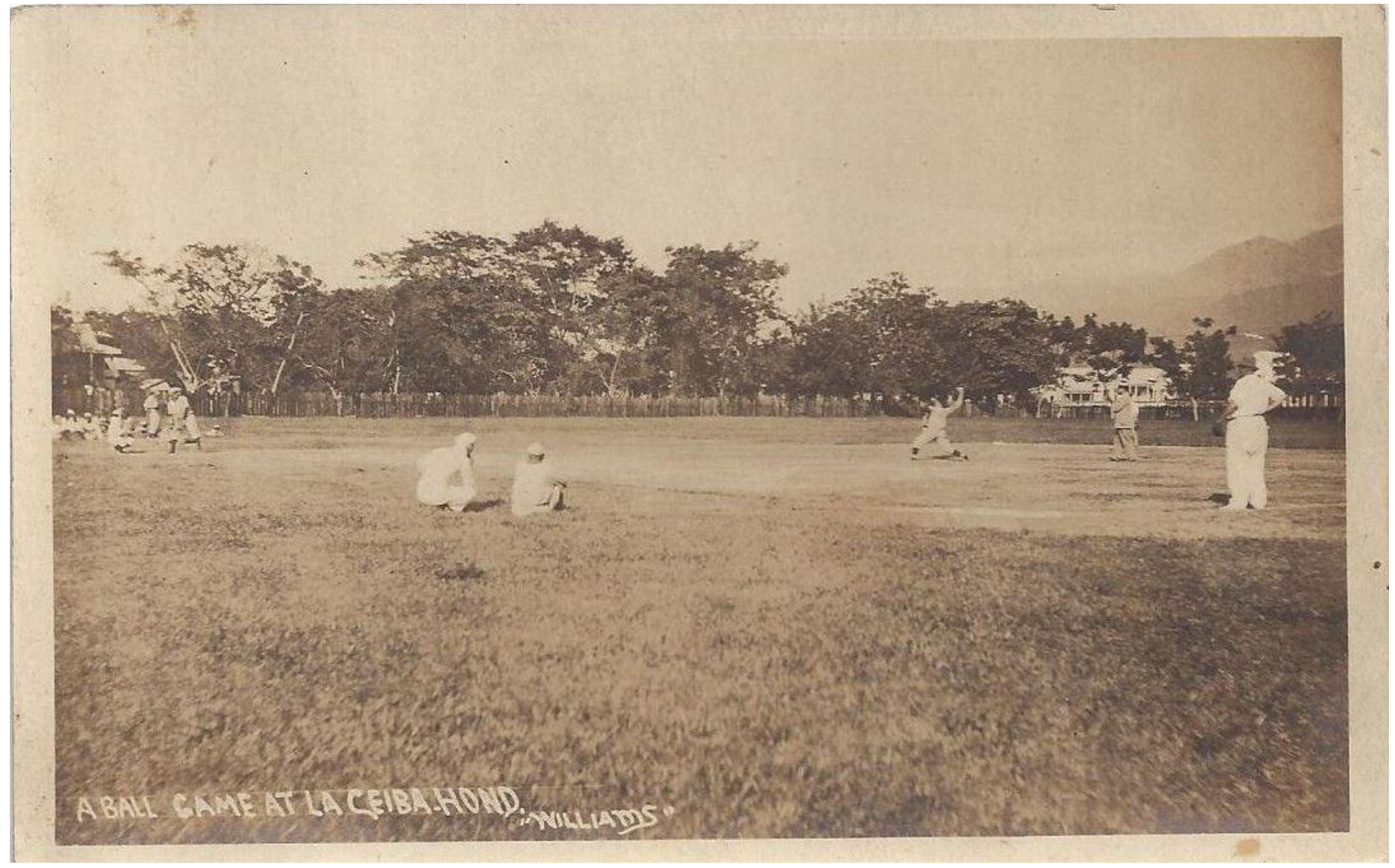

Un juego de "Base ball" o "Juego de pelota" como le llamaron en América Latina, en esta tarjeta postal obra de Arnold Teodhore Williams de 1930. Estos nuevos deportes, juegos y diversiones de la Modernidad se convirtieron a la postre en prácticas culturales muy frecuentes entre los sectores populares. De hecho, el fútbol y el béisbol se constituyeron en Honduras en los deportes más populares del siglo XX. 
Artigo original

Hegemonia - Revista Eletrônica do Programa de Mestrado em Direitos Humanos, Cidadania e Violência/Ciência Política do Centro Universitário Unieuro ISSN: $1809-1261$

UNIEURO, Brasília, número 24, Julho a Dezembro de 2018, pp. 110-259.

\section{POSTAL 95}

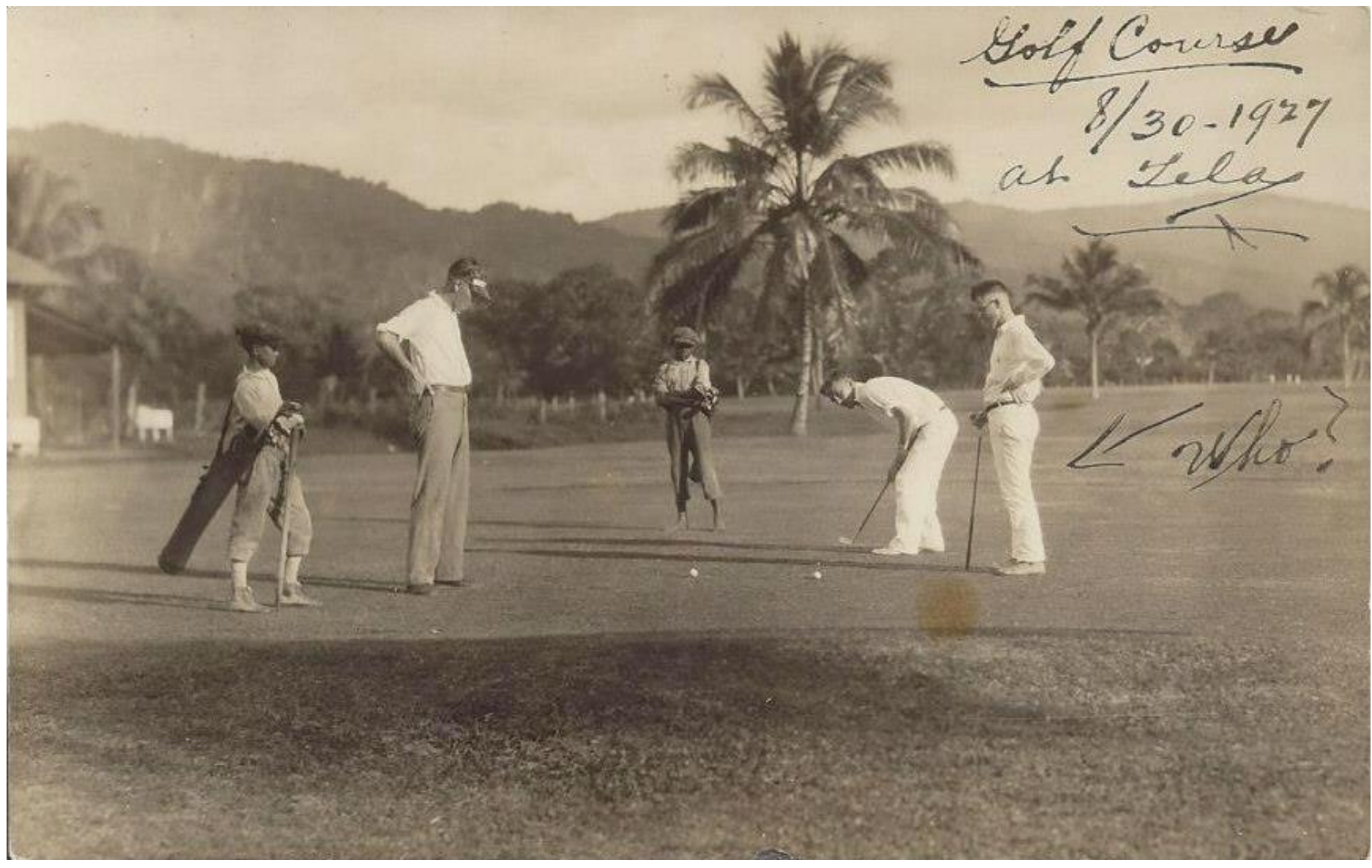

Bella estampa en esta tarjeta postal que nos muestra un "Juego de Golf" entre varios funcionarios gringos celebrado en el campo de la ciudad de Tela el 30 de agosto de 1927. Estas expresiones culturales novedosas y modernas daban cuenta de la llegada de costumbres "civilizatorias" según la opinión de los que opinaban favorablemente con la instalación de la "Banana Republic". 
Artigo original

Hegemonia - Revista Eletrônica do Programa de Mestrado em Direitos Humanos, Cidadania e Violência/Ciência Política do Centro Universitário Unieuro ISSN: 1809-1261

UNIEURO, Brasília, número 24, Julho a Dezembro de 2018, pp. 110-259.

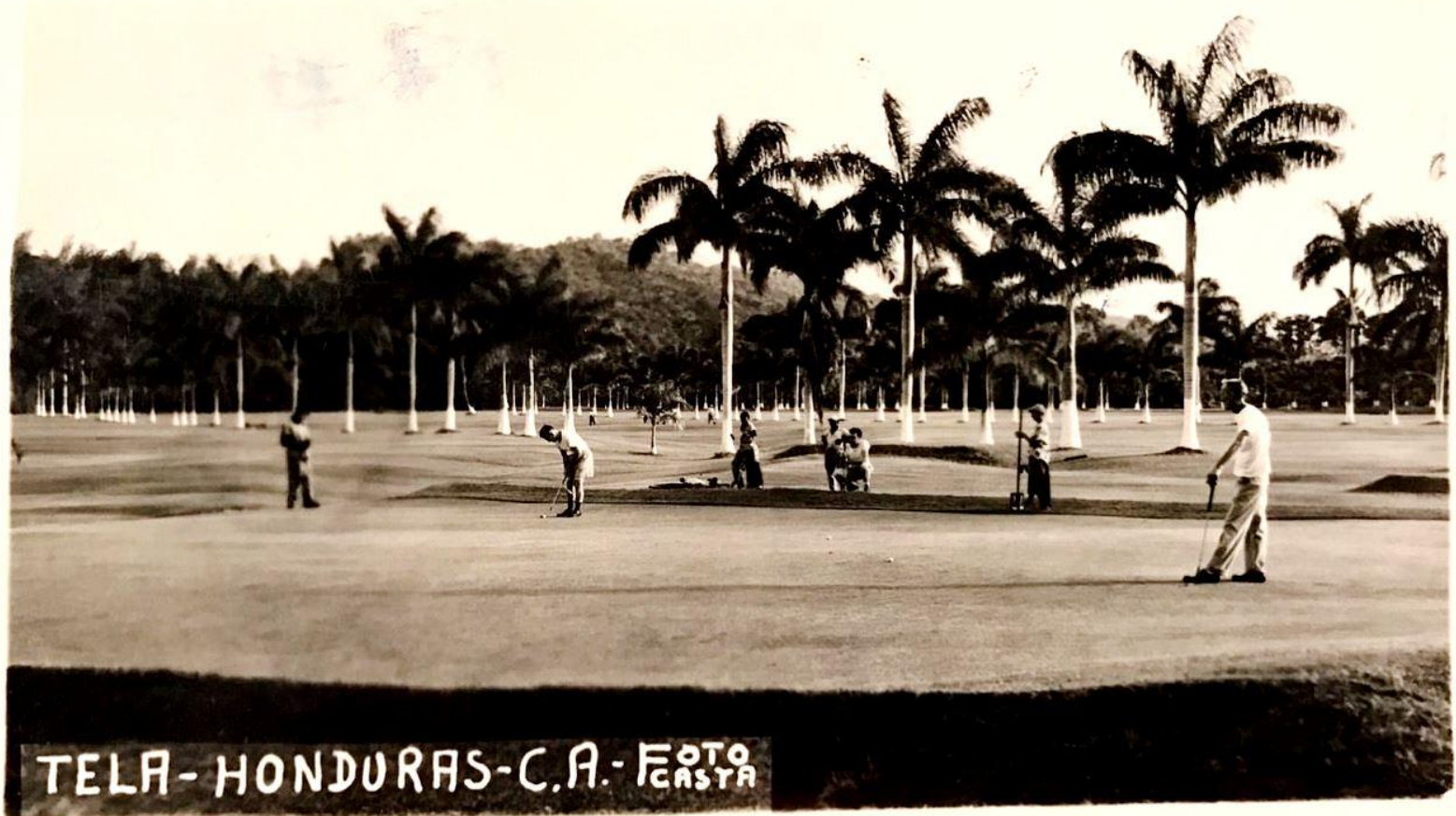

Otra bella tarjeta postal, editada por "Foto Casta", que muestra nuevamente el bello y cuidado campo de golf de la ciudad de Tela, Atlántida. En cada distrito bananero importante, como La Lima, Tela y La Ceiba, los funcionarios gringos se esmeraron en instalar este tipo de recintos, como campos de golf, hipódromos, canchas de béisbol, etcétera, con el objetivo de trasplantar la cultura hegemónica a estos lares de la "Banana Republic", e imponer su civilización sobre estas culturas a las que consideraban "bárbaras". 
Artigo original

Hegemonia - Revista Eletrônica do Programa de Mestrado em Direitos Humanos, Cidadania e Violência/Ciência Política do Centro Universitário Unieuro ISSN: 1809-1261

UNIEURO, Brasília, número 24, Julho a Dezembro de 2018, pp. 110-259.

POSTAL 97

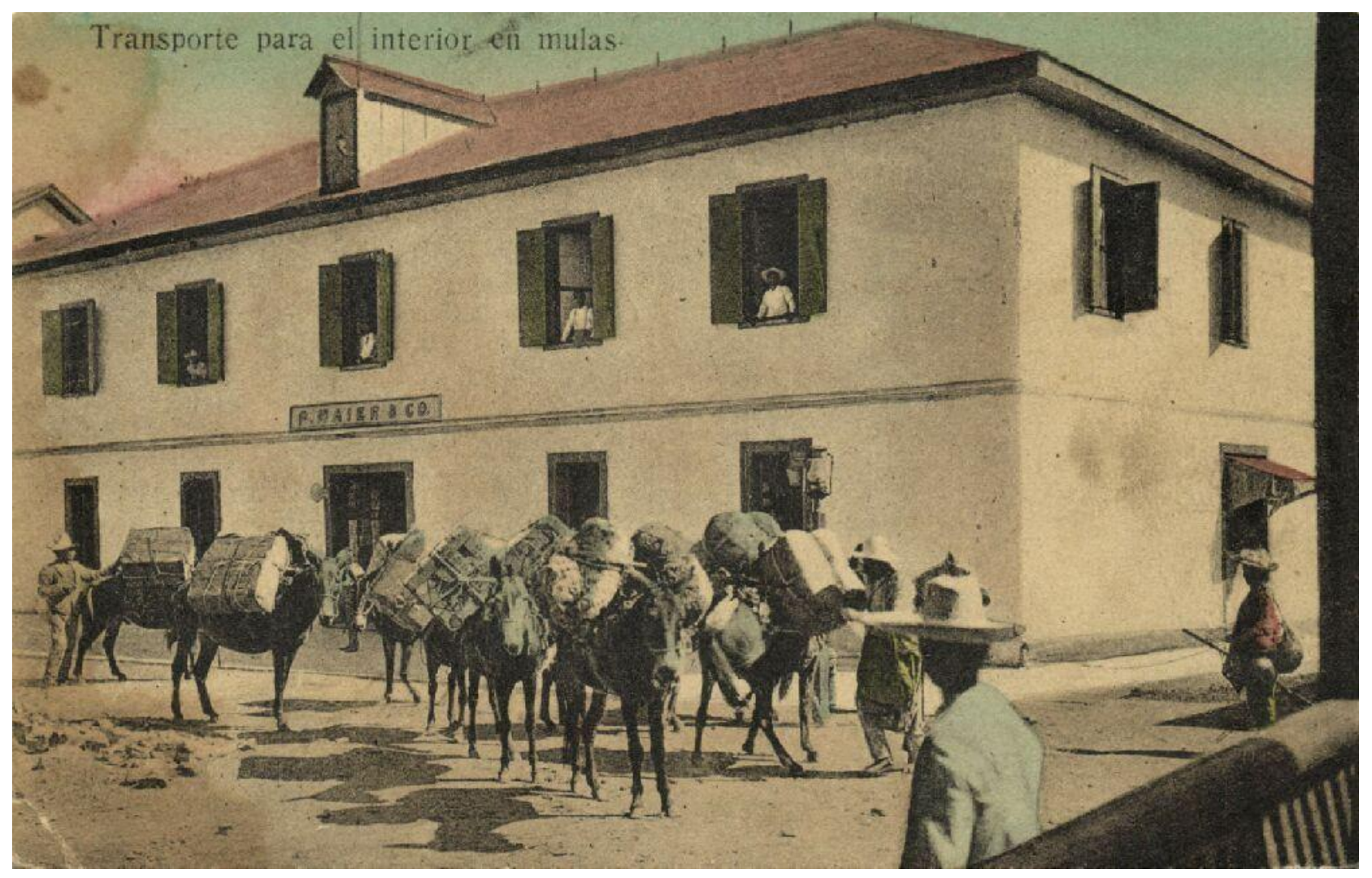

Tarjeta postal editada por el artista fotógrafo P. Maier \& y Cía, en 1910, que ilustra una recua de mulas que transportan mercaderías desde San Pedro Sula al interior de la República. A pesar de la llegada de todos esos sistemas modernos de comunicación, como el ferrocarril, el avión y los barcos, por muchas décadas las mulas continuaron siendo un relevante medio de transporte ante la escasez de vías de comunicación en el país. 
Artigo original

Hegemonia - Revista Eletrônica do Programa de Mestrado em Direitos Humanos, Cidadania e Violência/Ciência Política do Centro Universitário Unieuro ISSN: 1809-1261

UNIEURO, Brasília, número 24, Julho a Dezembro de 2018, pp. 110-259.

POSTAL 98

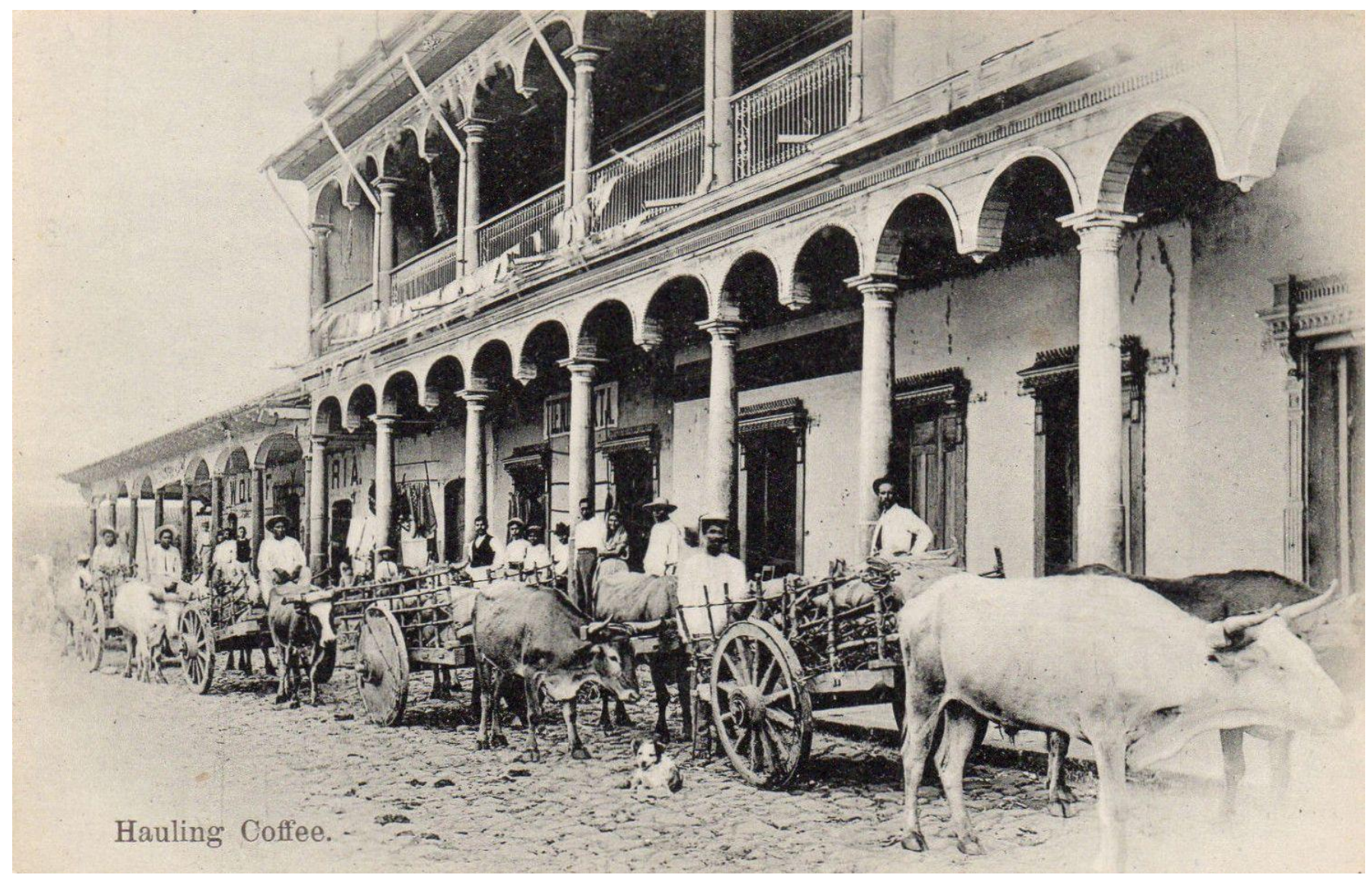

Carretadas de café procedentes de Santa Bárbara y Copán, llegan a San Pedro Sula para luego ser exportadas a Estados Unidos. La actividad bananera estimuló relativamente algunas otras actividades productivas en el interior de la república, como la producción de café, granos básicos, hortalizas y algunas actividades artesanales, que circulaban tanto para el comercio exterior como interior. 


\section{Artigo original}

Hegemonia - Revista Eletrônica do Programa de Mestrado em Direitos Humanos, Cidadania e Violência/Ciência Política do Centro Universitário Unieuro ISSN: $1809-1261$

UNIEURO, Brasília, número 24, Julho a Dezembro de 2018, pp. 110-259.

\section{POSTAL 99}

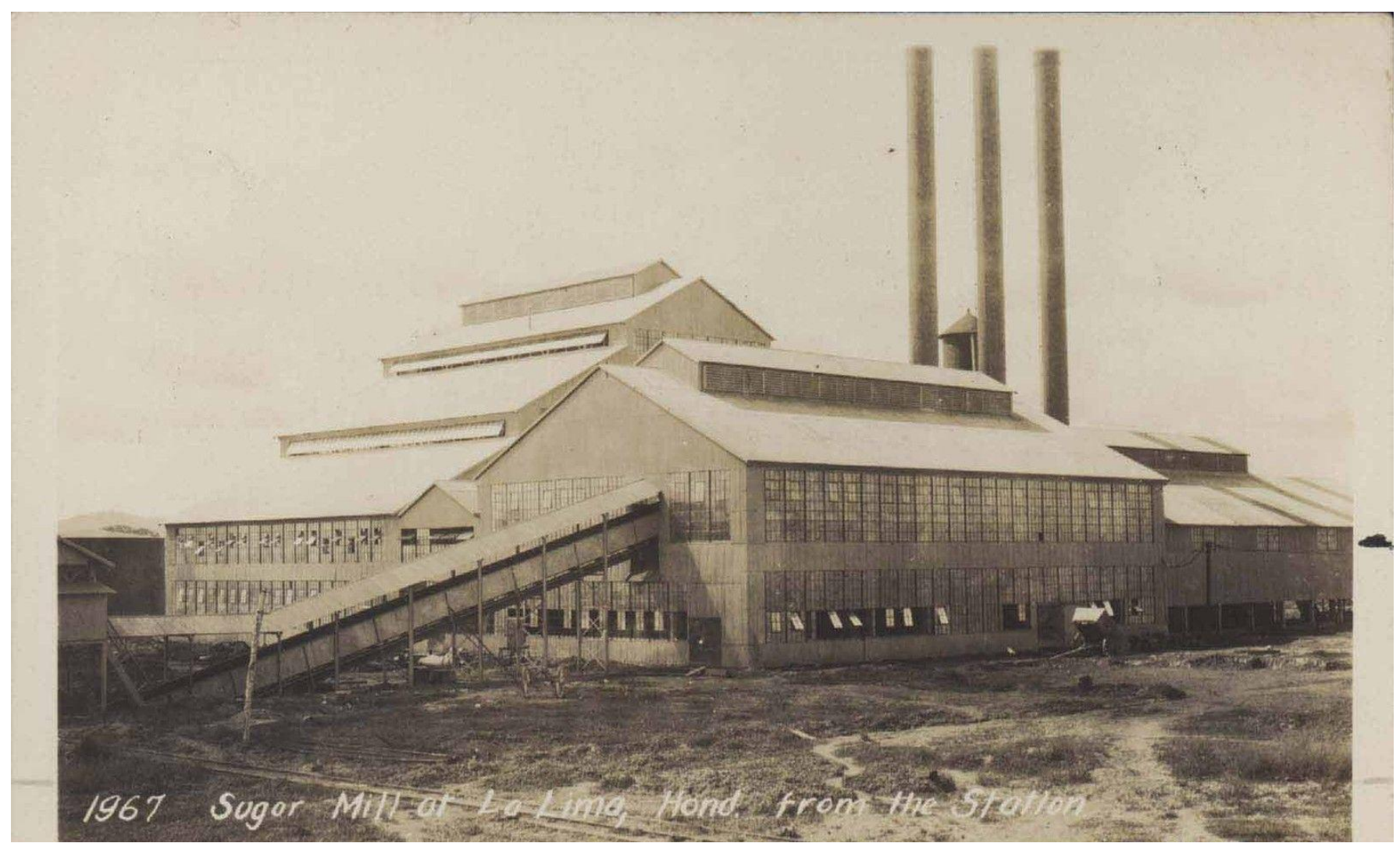

Tarjeta postal que muestra el legendario "Ingenio Azucarero" de la Lima Cortés, de los años treinta, seriada por el editor con el número 1967. Las compañías bananeras descubrieron que además del banano, también podían impulsar otros cultivos para el consumo interno y externo, como la producción de caña de azúcar, piñas, mangos, naranjas y cocos entre otros, lo cual diversificó la producción de artículos primarios. 
Artigo original

Hegemonia - Revista Eletrônica do Programa de Mestrado em Direitos Humanos, Cidadania e Violência/Ciência Política do Centro Universitário Unieuro ISSN: 1809-1261

UNIEURO, Brasília, número 24, Julho a Dezembro de 2018, pp. 110-259.

\section{POSTAL 100}

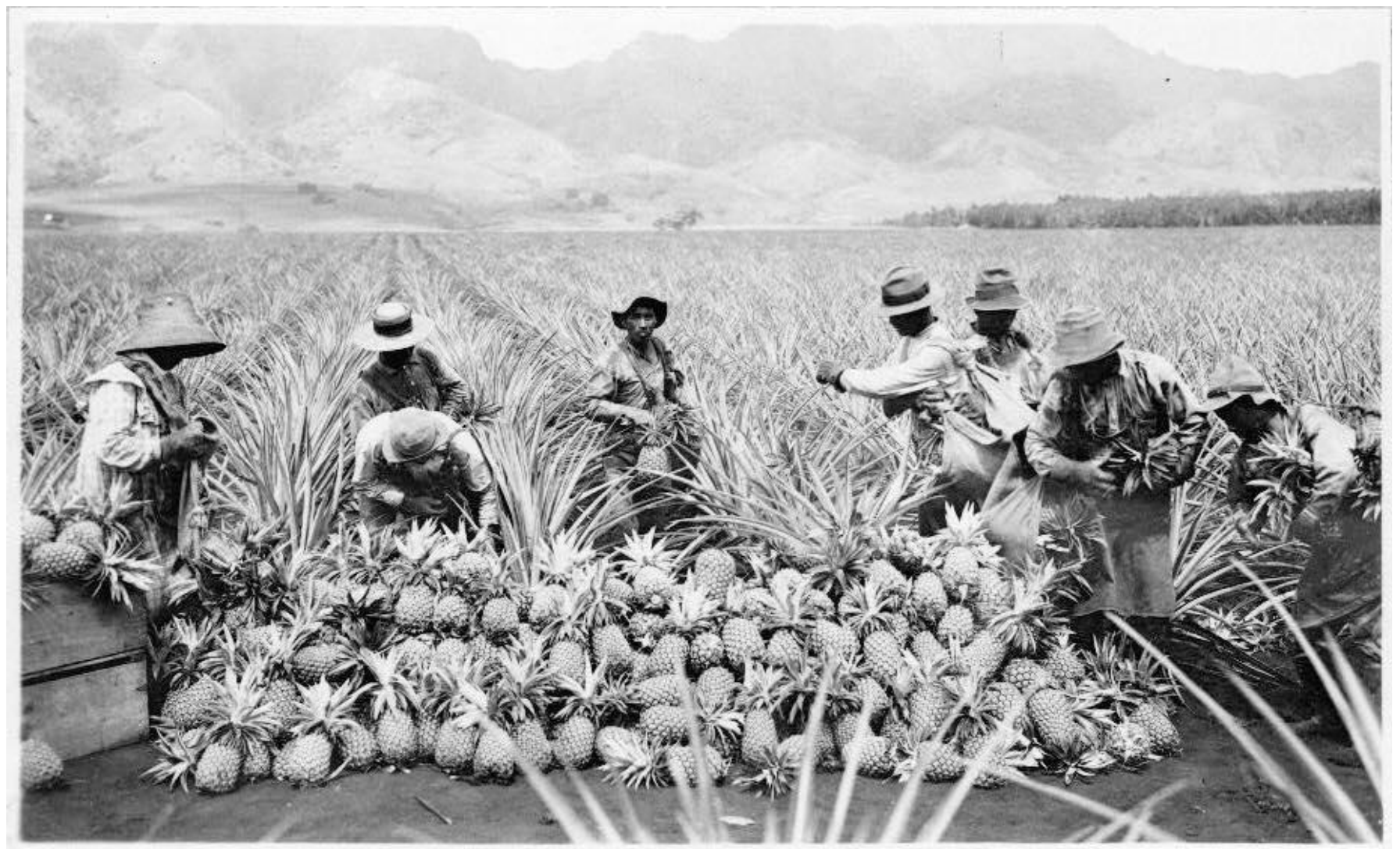

Bella postal que ilustra el corte de piñas, y al fondo la Sierra Nombre de Dios en las cercanías de La Ceiba. Este cultivo se fue imponiendo frente al banano en esa zona del departamento de Atlántida, y fue novelado en una interesante historia por el escritor Roberto Quesada titulada Los barcos, que narra las difíciles condiciones de trabajo que requiere ese tipo de cultivo. 